\title{
Environmental Management Performance Report July 2000
}

www.hanford.gov/empr/toc. htm

Prepared for the U.S. Department of Energy

Assistant Secretary for Environmental Management

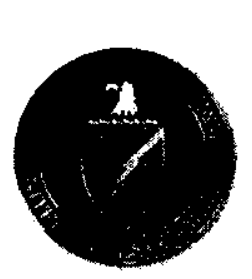

United States

Department of Energy

Richland Operations Office

P.O. Box 550

Richland, Washington 99352

Approved for Public Release; Further Dissemination Unlimited 
TRADEMARK DISCLAIMER

Reference herein to any specific commercial product, process,

or service by trade name, trademark, manufacturer, or

othenwise, does not necessarily constitute or imply its

endorsement, recommendation, or favoring by the United

States Government or any agency there of or its contractors or subcontractors.

This report has been reproduced from the best available copy. Available in paper copy and microfiche.

Available electronically at http://www.doe.gov/bridge. Available for a processing fee to the U.S. Department of Energy and its contractors, in paper, from:

U.S. Department of Energy

Office of Scientific and Technical Information

P.O. Box 62

Oak Ridge, TN 37831-0062

phone: 865-576-8401

fax: 865-576-5728

email: reports@adonis.osti.gov(423) 576-8401

Available for sale to the public, in paper, from:

U.S. Department of Commerce

National Technical Information Service

5285 Port Royal Road

Springfield, VA 22161

phone: 800-553-6847

fax: 703-605-6900

email: orders@ ntis.fedworld.gov

online ordering: http://www.ntis.gov/ordering.htm 


\section{RELEASE AUTHORIZATION}

Document

DOE/RI-99-83, Rev. 6

Number:

Document

Title:

Environmental Management Performance Report

July 2000

This document, reviewed in accordance with DOE Order 241.1, "Scientific and Technical

Information Management, "and 241.1-1, "Guide to the Management of Scientific and Technical Information," does not contain classified or sensitive unclassified information and is:

\section{APPROVED FOR PUBLIC RELEASE}

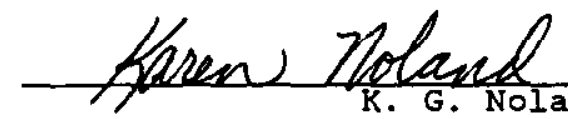

Lockheed Martin Services, Inc.

Document Control/Information Clearance

Roviowed for Applled Techoology, Bushoss Songltive, Classlified Copyrighted, Export Controlled, Patont, Porgonal/private, Propriotary, Protocted CRADA, Trademark, Unclesglfiod Coptrolled Nucloar Information.

Iradamark Disclaimer. Roforonce heroin to any spectific commoreial product, process, or sorvice by trade name, trademark, manufacturer, or otherwiso, does not necossarlly constitute or lnply 1 ts ondorsonent, reccmendation, or favor ing by the Uaited States Govirnment or any agency thoreof or its contrectors or subcontractors. The views and opinions of authors expressed herein do not necessarily state or reflect those of the United States Government or any agency thereof. This roport hes been roproduced from the best avillable copy.

Printed in the United states of Mmerica. 


\section{INTRODUCTION}

The purpose of the Environmental Management Performance Report (EMPR) is to provide the 1 Department of Energy Richland Operations Office's (DOE-RL's) report of Hanford's Environmental Management (EM) performance by:

- Project Hanford Management Contract (PHMC) through Fluor Hanford, Inc. (FH) and its subcontractors,

- Environmental Restoration Contract through Bechtel Hanford, Inc. (BHI), and its subcontractors,

- Pacific Northwest National Laboratories (PNNL) for Science and Technology support to the EM Mission, and

- Office of Safety Regulation of the TWRS Privatization Contractor.

This report is a monthly publication that summarizes EM Site performance under RL Operations Office. It is organized by the four sections listed above, with each section containing an Executive Summary and Area Performance Summaries. A glossary of terms is provided at the end of this report for reference purposes.

The report date on the cover reflects the month in which the report is released. 


\section{Project Hanford Management Contractor Environmental Management Performance Report to \\ DOE Richland Operations Office \\ July 2000}

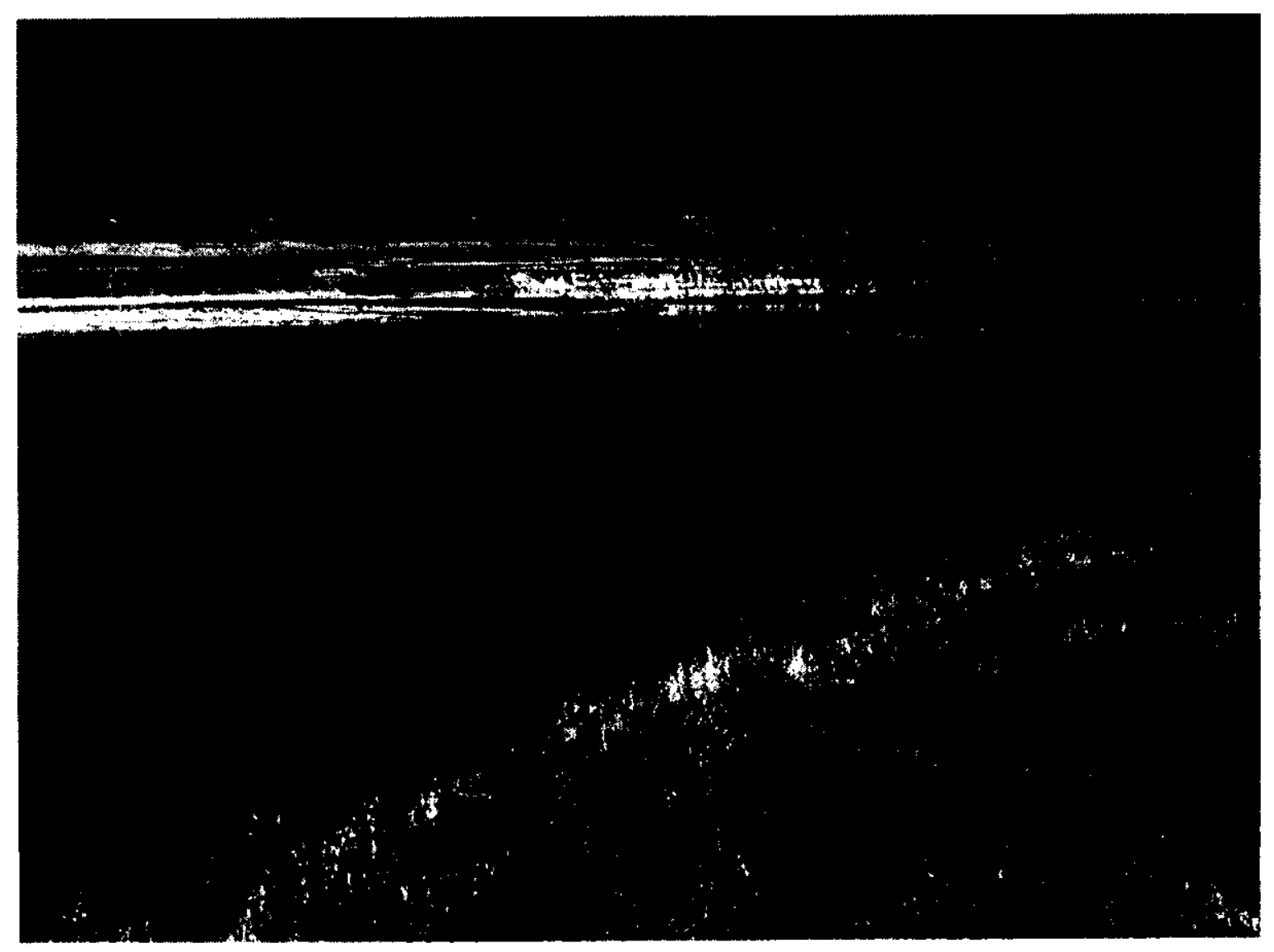

Fluor Hanford

A Fluor Global Services Company 


\section{Table of Contents}

Section

Executive Summary

The Plateau

Waste Management. B: 1

Analytical Services (222-S, HASP, WSCF).......................... B: 2

Nuclear Material Stabilization .......................................... C: 1

The River

River Corridor ............................................................... C: 2

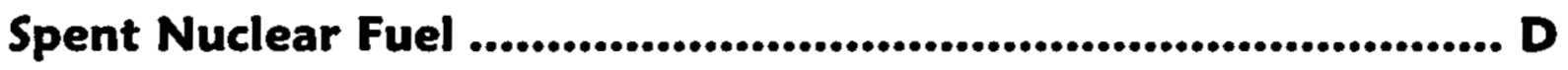

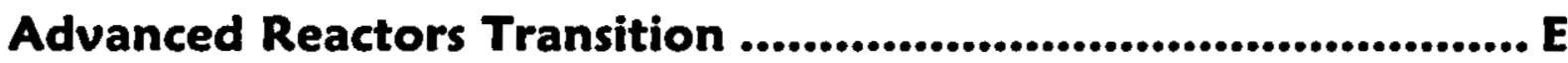

EM - 50 Science \& Technology Activities............................... F

\section{The Future}

HAMMER

\section{Multiple Outcomes}

Landlord $\mathbf{H}$

Support.

National Programs 


\section{INTRODUCTION}

The purpose of this report is to provide the Department of Energy Richland Operations Office 1 (DOE-RL) a monthly summary of the Project Hanford Management Contractor's (PHMC) Environmental Management (EM) performance by Fluor Hanford (FH) and its subcontractors. In addition to project-specific information, it includes some PHMC-level data not detailed elsewhere in the report.

Section A, Executive Summary, provides an executive level summary of the cost, schedule, and technical performance described in this report. It summarizes performance for the period covered, highlights areas worthy of management attention, and provides a forward look to some of the upcoming key performance activities as extracted from the PHMC baseline.

The remaining sections provide detailed performance data relative to each individual Project (e.g., Waste Management, Spent Nuclear Fuels, etc.), in support of Section A of the report. Unless otherwise noted, the Safety, Conduct of Operations, and Cost/Schedule data contained herein is as of May 31, 2000. All other information is updated as of June 22, unless otherwise noted. 


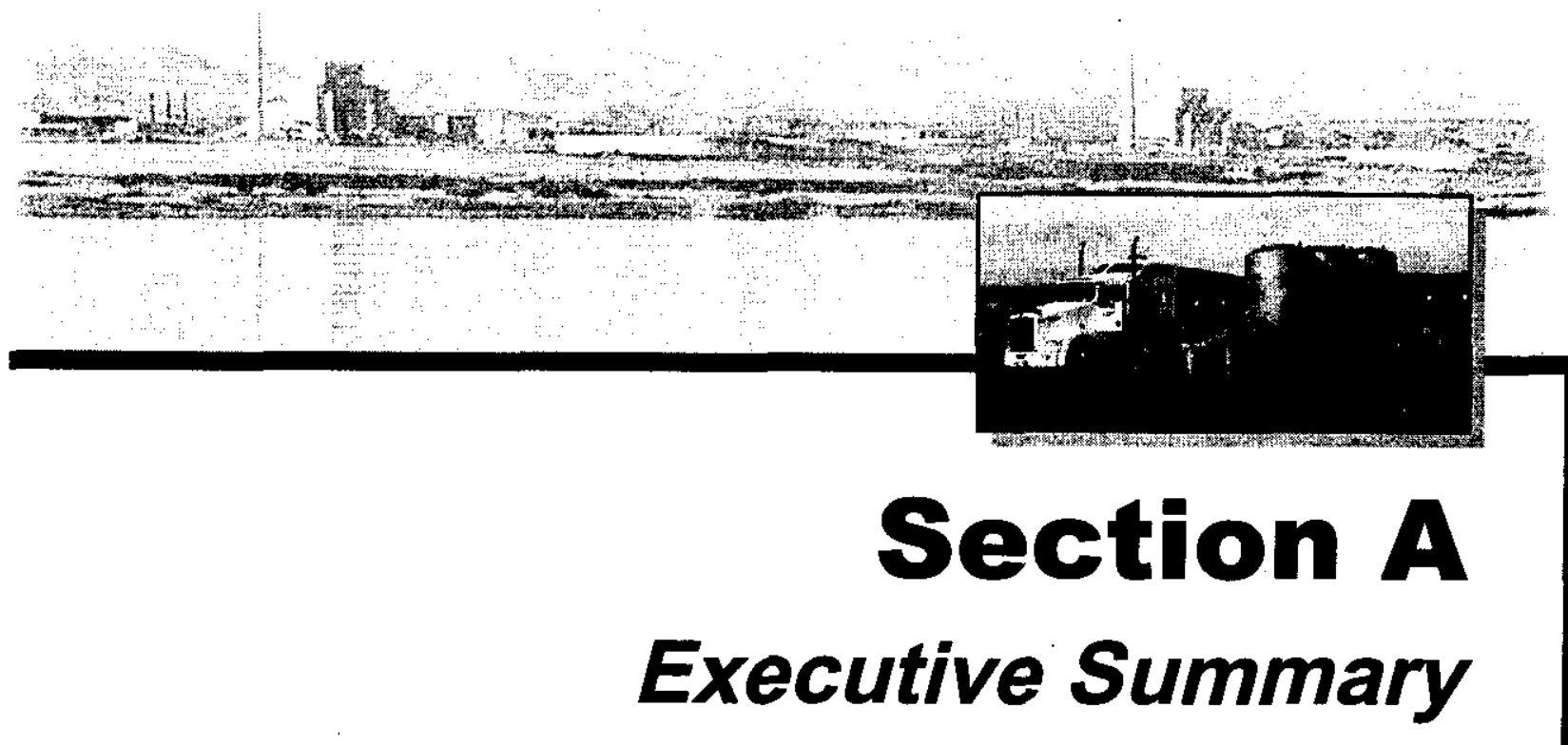




\section{INTRODUCTION}

7 his section provides an executive level summary of the performance information covered in this report and is intended to bring to Management's attention that information considered to be most noteworthy. All cost, schedule, milestone commitments, performance measures, and safety data is current as of May 31 . Accomplishments, Issues and Integration items are current as of. June 12 unless otherwise noted.

The section begins with a description of notable accomplishments that have occurred since the last report and are considered to have made the greatest contribution toward safe, timely, and costeffective clean up. Following the accomplishment section is an overall fiscal year-to-date summary analysis addressing cost, schedule, and milestone performance. Overviews of safety ensue. The next segment of the Executive Summary, entitled Critical Issues, is designed to identify the high-level challenges to achieving cleanup progress.

The next section includes FY 2000 EM Management Commitment High Visibility Project Milestones and Critical Few Performance Measures.

The Key Integration Activities section follows next, highlighting PHMC activities that cross contractor boundaries and demonstrate the shared value of partnering with other Site entities to accomplish the work. Concluding the Executive Summary, a forward-looking synopsis of Upcoming Planned Key Events is provided.

\section{NOtABle ACCOMPLISHMENTS}

- The first TRUPACT-II shipping container has been loaded and leak tested. Thirty-three drums have been loaded for shipment in three TRUPACT-II shipping containers. The TRUPACT-IIs will remain loaded and "ready for shipment" pending resolution of the New Mexico Environment Department issues.

- The Hanford Mixed Waste Management Program Implementation Plan for the Ecology Final Determination on Land Disposal Restriction (LDR) was approved on June 12, 2000.

- The 242A Evaporator campaign (scheduled for completion May 8) completed on May 5. The campaign processed 1.3 million gallons of high-level radioactive waste with an all-time high operational efficiency of $99.3 \%$.

- As of June 16,2000 a total of 290 cans of Plutonium oxides and sludges have been stabilized through thermal stabilization ( 35 additional items since last report).

- Good progress was made toward closeout of the actions required by the B Plant transfer Memorandum of Agreement (MOA). There are a few issues remaining, to include aerosol challenge test of the north filter train and restart of the B Plant exhaust system by July 28 , 2000 .

- Twelve grout containers of the planned seventeen have now been shipped to the Low-level Burial Grounds in the 200 Area. Shipment of this waste is critical to meeting TPA milestone M-89-02, "Complete Removal of 324 Building Radiochemical Engineering Cell (REC) B Cell Mixed Waste (MW) and Equipment," due November 2000.

- The second shipment of six Multi-Canister Overpacks (MCOs) was received from Joseph Oat, Inc. ahead of schedule. 


\section{Performance Data and Analysis}

he following provides a brief synopsis of overall PHMC Environmental Management (EM)
cost, schedule, and milestone performance.

\section{FY 2000 Cost and Schedule Performance}

Cost Performance - Fiscal-year-to-date (FYTD) cost performance reflects a four percent ( $\$ 14.0$ million) unfavorable cost variance that is within the established $+10 /-5$ percent threshold.

Schedule Performance - There is a FYTD six percent ( $\$ 23.3$ million) unfavorable schedule variance that is at the established $+10 /-7.5$ percent threshold.

Data Through May 2000

\begin{tabular}{|c|c|c|c|c|c|c|c|c|c|}
\hline & \multicolumn{5}{|c|}{ Current Fiscal Year Performance ( $\mathbf{S} \times$ Milliton) } & \multirow{3}{*}{ PEM } & \multirow{3}{*}{ FYSF } & \multirow{3}{*}{ EAC } \\
\hline & & \multicolumn{3}{|c|}{ FYTD } & \multirow{2}{*}{$\begin{array}{l}\text { Schedule } \\
\text { Variance }\end{array}$} & \multirow{2}{*}{$\begin{array}{c}\text { Cost } \\
\text { Variance }\end{array}$} & & & \\
\hline & & $\overline{\text { BCWS }}$ & $\overline{\text { BCWP }}$ & ACWP & & & & & \\
\hline \multicolumn{2}{|c|}{ 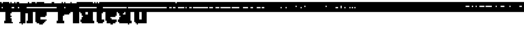 } & & & & & & & & \\
\hline 1.2 & $\begin{array}{l}\text { Waste Management } \\
\text { TP02,WM03-05 }\end{array}$ & 69.4 & 67.2 & 67.9 & (2.2) & $(0.6)$ & 107.1 & 108.2 & 108.2 \\
\hline 1.2 .4 & $\begin{array}{l}\text { Anslytical Sves (222-S,HASP,WSCF) } \\
\text { WM06 }\end{array}$ & 18.3 & 18.0 & 19.1 & $(0.3)$ & (1.1) & 27.1 & 27.6 & 28.0 \\
\hline 1.4 .5 & $\begin{array}{l}\text { Nuclear Materials Stabilization } \\
\text { TPOS }\end{array}$ & 85.3 & 70.1 & 80.3 & (15.2) & $(10.2)$ & 124.1 & 121.9 & 127.5 \\
\hline \multicolumn{2}{|c|}{ The River } & $\mathbf{1 7 3 . 1}$ & $\mathbf{1 5 5 . 4}$ & 167.3 & $(17.7)$ & (11.9) & $\overline{258.4}$ & $\mathbf{2 5 7 . 7}$ & $\mathbf{2 6 3 . 7}$ \\
\hline 1.4 & $\begin{array}{l}\text { River Corridor } \\
\text { TP01,TP04,TP08,TP10,TP12,TP14 }\end{array}$ & 39.1 & 39.6 & 37.0 & 0.5 & & 60.3 & 58.9 & 59.1 \\
\hline 1.3 & $\begin{array}{l}\text { Spent Nuclear Fuel } \\
\text { WM0l }\end{array}$ & 139.7 & 139.8 & 144.9 & 0.1 & (3.1) & 197.2 & 201.3 & 201.3 \\
\hline 1.12 & Advanced Reactors (EM) & 1.0 & 1.0 & 0.9 & $(0.0)$ & 0.1 & 1.7 & 1.1 & 1.3 \\
\hline & $\begin{array}{l}\text { Technology Development } \\
\text { (EM-s0) }\end{array}$ & 13.3 & 12.2 & 11.4 & (1.1) & 0.8 & 22.8 & 22.9 & 22.9 \\
\hline \multicolumn{2}{|c|}{$\begin{array}{l}\text { Subtotal The River } \\
\text { The Future }\end{array}$} & 193.1 & $\overline{192.5}$ & $\overline{194.2}$ & (0.6) & $\overline{(1.6)}$ & 282.1 & $\overline{284.2}$ & $\mathbf{2 8 4 . 5}$ \\
\hline & $\begin{array}{l}\text { HAMMER } \\
\text { HM01 }\end{array}$ & 4.0 & 3.7 & 3.6 & $(0.2)$ & 0.1 & 5.9 & 5.9 & 5.9 \\
\hline \multicolumn{2}{|c|}{$\begin{array}{l}\text { Subtotal The Future } \\
\text { Multiple Outcomes }\end{array}$} & $\overline{4.0}$ & $\overline{3.7}$ & $\overline{3.6}$ & $\overline{(0.2)}$ & 0.1 & 5.9 & $\overline{5.9}$ & 5.9 \\
\hline & $\begin{array}{l}\text { Landlord } \\
\text { TP13 }\end{array}$ & 8.0 & 7.4 & 5.4 & $(0.7)$ & 2.0 & 14.1 & 12.2 & 13.9 \\
\hline & $\begin{array}{l}\text { Mission Support } \\
\text { OT01, OTO4 }\end{array}$ & 25.6 & 21.3 & 24.6 & (4.4) & (3.3) & 45.6 & 47.0 & 46.9 \\
\hline \multirow{2}{*}{$\begin{array}{l}1.11 \& \\
\text { WM07 }\end{array}$} & $\begin{array}{l}\text { National Programs } \\
\text { OT02, WM07 }\end{array}$ & 3.0 & 3.3 & 2.4 & 0.2 & 0.8 & 5.8 & 4.6 & 6.1 \\
\hline & Subtotal Multiple Outcomes & 36.7 & $\overline{31.9}$ & 32.4 & $(4.8)$ & $(0.5)$ & 65.5 & 63.8 & 67.0 \\
\hline & Total Phinc projects & 406.9 & 383.6 & 397.5 & $(25.3)$ & (14.0) & 611.8 & 611.6 & 621.1 \\
\hline
\end{tabular}

Notes: Column headings (BCWS, BCWP, FYSF, EAC, etc.) are defined in the glossary at the end of the report. Calculations are based on Project Baseline Summary detail. Waste Management, Analytical Services, River Corridor, and Nuclear Materials Stabilization have included RL-Directed costs (e.g. steam and laundry) in the PEM BCWS. Advanced Reactors (EM) have included steam. Technology Development does not include ORP/RPP TTPs currently reported in the RL Dataset in the HQ-IPABS-PEM.

Funds Management - Although earned value measures are currently close to or within established thresholds, the PHMC is currently projecting a potential overrun in the Project Completion Control Point. Project Fiscal Year Spend Forecast (FYSF) data is continuing to be analyzed in comparison to available funds, and recent trends indicate that without action, costs could exceed funds. Management has taken aggressive steps designed to correct this situation and 
preliminary data indicate that the actions are making significant contributions toward cost reductions. In addition, an internal reprogramming package was submitted to $R L$ that will transfer \$5M from the Post 2006 control point to the Project Completion control point. This transfer will help to balance the cost problem between the control points, but will not totally resolve the overall funds management issue. The PHMC will monitor costs very closely and with increased frequency to assure that the management actions yield the necessary results and that costs do not exceed funds.

The following Cost/Schedule and Variance to Plan chart provides an overall graphical view of fiscal year to date performance and cost and schedule performance indicators.

\section{Fy 2000 Cost / Schedule Performance Cumulative to Date Status}

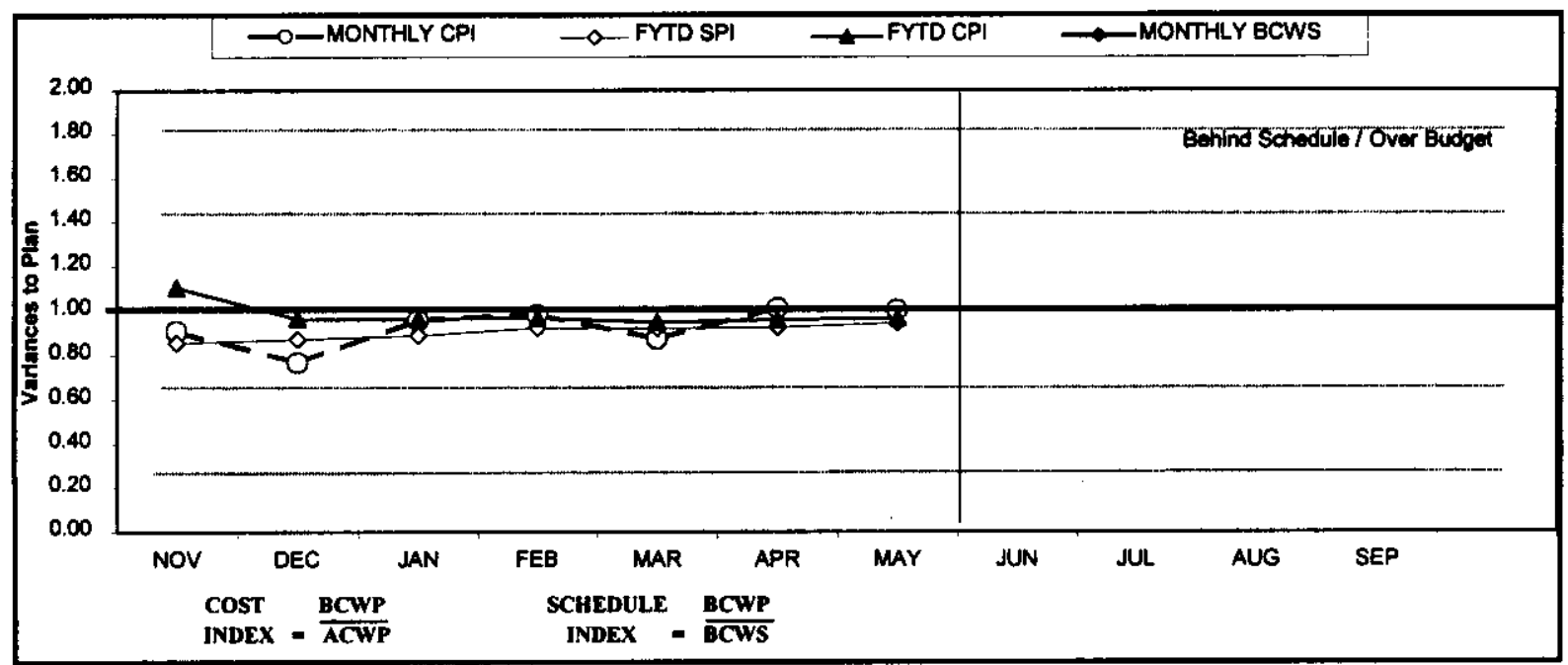

\begin{tabular}{|c|c|c|c|c|c|c|c|c|c|c|c|c|}
\hline FYabio & OCl & NOV & Diac & JAN & FES & BAR & APR & WAY & JUN & JUL & AOUS & $\mathbf{S E F}$ \\
\hline MONIHLYSPI & 0.91 & 0.82 & 0.91 & 0.94 & T.06 & 0.91 & 0.93 & 1.03 & & & & \\
\hline MONIFILYCPI & 1.63 & 0.91 & 0.77 & 0.96 & 0.98 & 0.87 & T.01 & 1.00 & & & & \\
\hline FYTDSPI & 0.91 & 0.85 & 0.87 & 0.89 & 0.92 & 0.92 & 0.92 & 0.94 & & & & \\
\hline FYTD CAP & T.6T & 1.10 & 0.90 & 0.96 & 0.97 & 0.95 & $0 \%$ & 0.96 & & & & \\
\hline MONTHLY BCWS & 32,593 & 533,767 & 43,044 & 45,616 & 46,841 & 38,627 & 31,19 & 61,931 & 43,095 & 44,044 & 35,241 & 35,063 \\
\hline MONTHLY BCWP & 29,521 & 544,110 & 39,143 & 42,925 & 49,641 & 33,309 & 48,692 & 63,845 & & & & \\
\hline MONIFLY RCWP & $\begin{array}{l}5 \\
5,079\end{array}$ & 548,593 & 30,991 & 44,809 & 50,494 & 61,261 & 48,57 & 63,711 & & & & \\
\hline FYTD BCWS & 534,194 & 589,568 & 134,234 & 5781,586 & 230,337 & 290,728 & 343,763 & 3406,867 & 5452,340 & 498,846 & 356,218 & 611,837 \\
\hline FYTD BCWP & 531,083 & 576,592 & T16,984 & 161,408 & 212,355 & 267,234 & $3 \quad 317,970$ & $5-383,374$ & & & & \\
\hline FPTD ACWP & S 19,333 & 569,374 & $T 21,431$ & 167,678 & 219,385 & 282,005 & I 331,991 & I 397,334 & & & & \\
\hline
\end{tabular}

\section{Milestone Performance}

Milestones represent significant events in project execution. They are established to provide a higher level of visibility to critical deliverables and to provide specific status about the accomplishment of these key events. Because of the relative importance of milestones, the ability to track and assess milestone performance provides an effective tool for managing the PHMC EM cleanup mission.

FYTD milestone performance (Enforceable Agreement [EA], U.S. Department of EnergyHeadquarters [DOE-HQ], and RL) shows that 37 of 52 ( 72 percent) approved baseline milestones were completed on or ahead of schedule, 7 milestones (13 percent) were completed late, and 8 
milestones (15 percent) are overdue. The eight overdue milestones are associated with four projects: Nuclear Material Stabilization-four, River Corridor-one, Environmental Management (EM)-50-two, and Mission Support-one. These overdue milestones do not share a common cause.

In addition to the FY2000 milestones described above, there are four overdue milestones from the prior fiscal year (FY1999). Further details regarding these milestones may be found in the Project Sections.

FY 2000 information is depicted graphically below and on the following page. For additional details related to the data in the graphs and prior year milestones, refer to the relevant project section titled "Milestone Exception Report."

FY 2000 information reflects the current approved baseline. Changes in both the number and type of milestones from month to month are the result of Baseline Change Requests (BCRs) approved during the year.

\begin{tabular}{|c|c|c|c|c|c|c|c|c|}
\hline \multirow[b]{2}{*}{ MILESTONE TYPE } & \multicolumn{4}{|c|}{ FISCAL YEAR-TO-DATE } & \multicolumn{3}{|c|}{ REMAINING SCHEDULED } & \multirow[b]{2}{*}{$\begin{array}{c}\text { TOTAL } \\
\text { FY } \\
2000\end{array}$} \\
\hline & $\begin{array}{c}\text { Completed } \\
\text { Early }\end{array}$ & $\begin{array}{l}\text { Completed } \\
\text { On } \\
\text { Schedule }\end{array}$ & $\begin{array}{c}\text { Completed } \\
\text { Late }\end{array}$ & Overdue & $\begin{array}{c}\text { Forecast } \\
\text { Early }\end{array}$ & $\begin{array}{l}\text { Forecast On } \\
\text { Schedule }\end{array}$ & $\begin{array}{c}\text { Forecast } \\
\text { Late }\end{array}$ & \\
\hline Enforceable Agreement & 78 & $\sqrt{3}$ & 0 & 7 & 0 & 11 & 0 & 33 \\
\hline DOE-HQ & 0 & 0 & 0 & 7 & 0 & 3 & 0 & 4 \\
\hline$R L$ & 10 & 6 & 7 & 6 & 0 & 44 & 0 & 73 \\
\hline Total Project & 28 & 9 & 7 & 8 & 0 & 58 & $\overline{0}$ & 110 \\
\hline
\end{tabular}
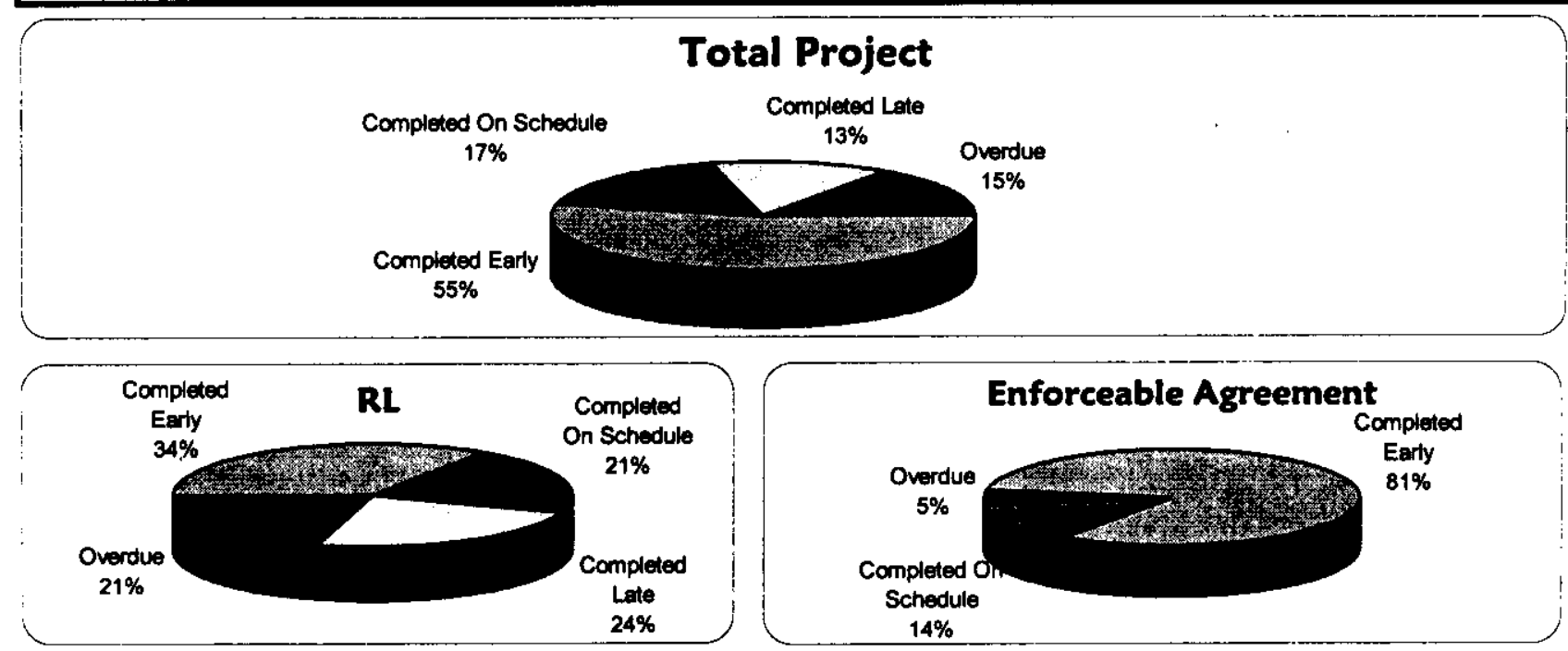
MILESTONE EXCEPTIONS
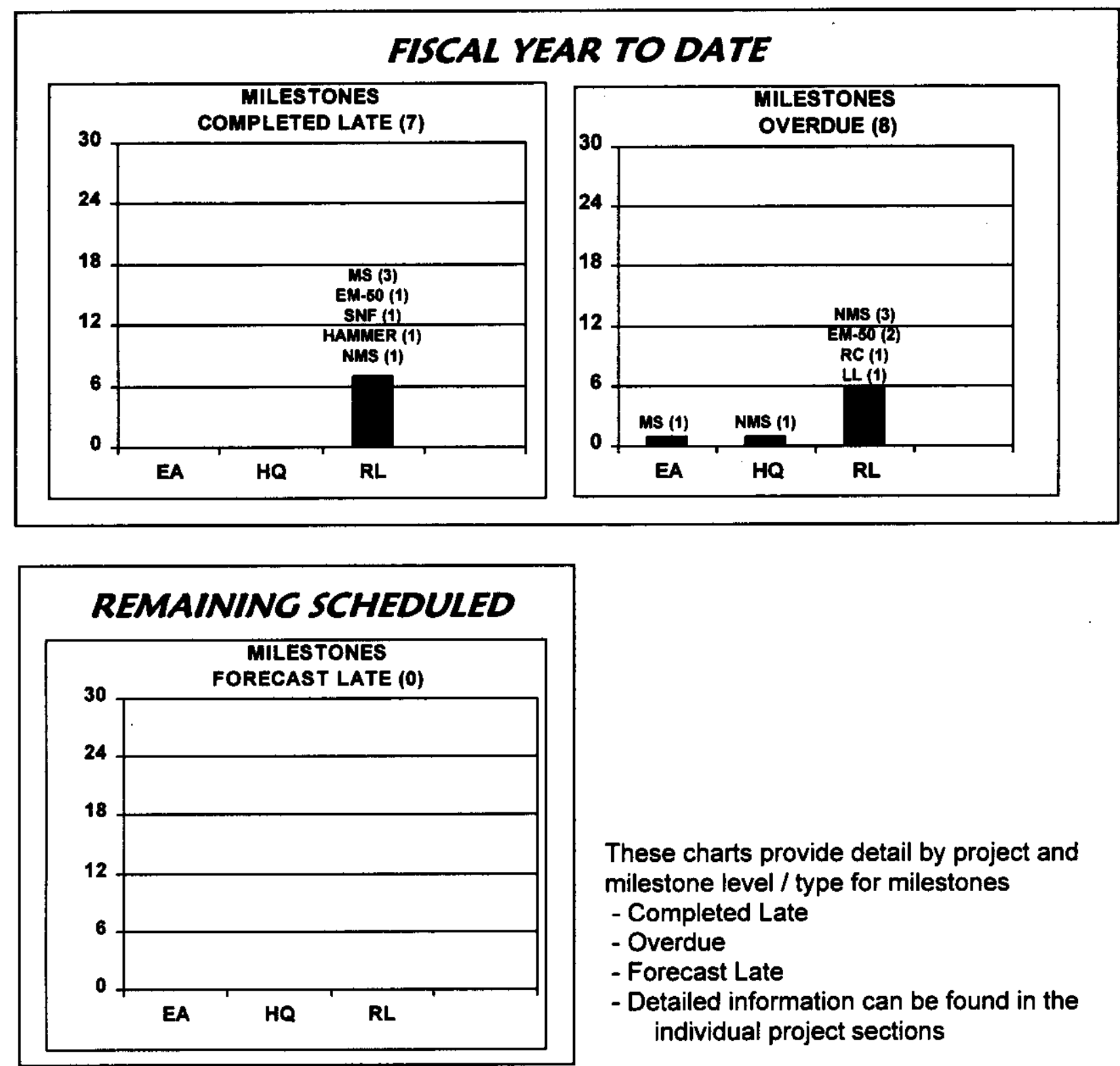

These charts provide detail by project and milestone level / type for milestones

- Completed Late

- Overdue

- Forecast Late

- Detailed information can be found in the individual project sections 


\section{SAFETY OVERVIEW}

The focus of this section is to document trends in occurrences. Improvements in these rates are 1 due to the efforts of the PHMC workforce as they implement the Integrated ES\&H Management System (ISMS), work towards achieving Voluntary Protection Program (VPP) "star" status, and accomplish work through Enhanced Work Planning (EWP). Safety and health statistical data is presented in this section.

\section{Significant SAfETY AND HEalth EVENTS}

Rates have been stable for over two years. This safety performance plateau has been recognized by the safety organizations, and Fluor Hanford kicked off its Integrated Safety Approach initiative on December 6, 1999 in order to take safety performance to a new level. This initiative focuses on the "people side" of accident prevention.

\section{Total OSHA Recordable Case Rate}

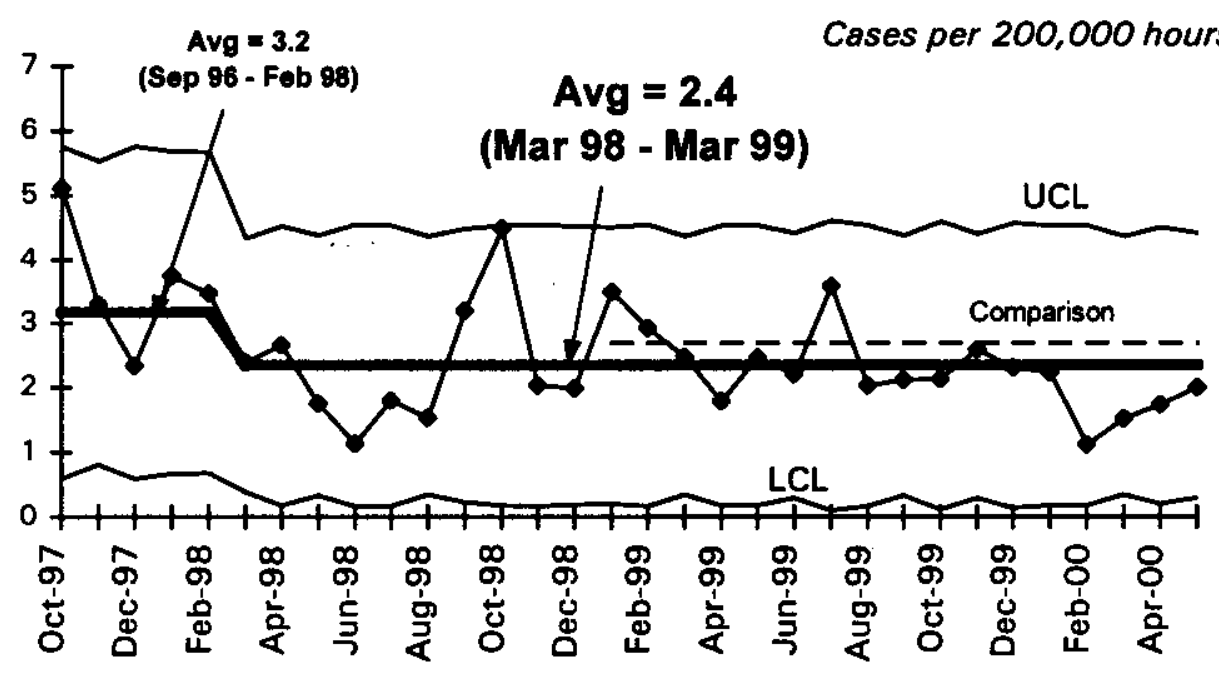

FY $1999=2.6$

FY $2000=2.0$

Contractor Comparison

Average $=2.7$ (CY99)

The past six months have been below average, and a seventh will be statistically significant.

$\mathrm{FH}$ is implementing a corrective action program to target an OSHA Recordable Case Rate of 0.9 . The Fluor Global Services goal is 1.0 . This is in line with Fluor's corporate value of safety and our commitment to the safe clean-up of the Hanford Site.

Six of FH's major projects and service organizations are achieving OSHA Recordable Case Rates of less than 1.0. 


\section{OSHA LOST/RESTRICTED WORKDAY CASE RATE}

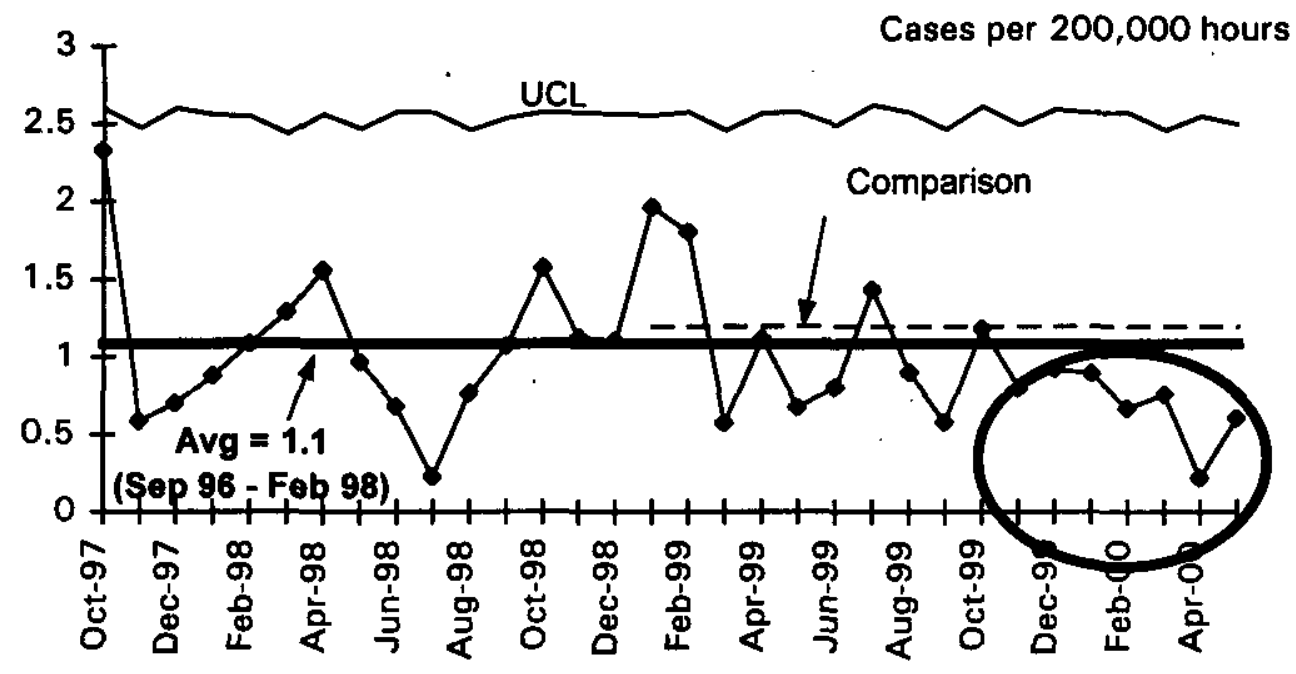

FY $1999=1.1$

FY 2000 to date $=0.75$

Contractor Comparison

Average $=1.2$ (CY99)

The past seven months in a row have been below average, a significant decrease. Five million hours have been worked since the last lost away workday injury.

\section{First Aid Case Rate}

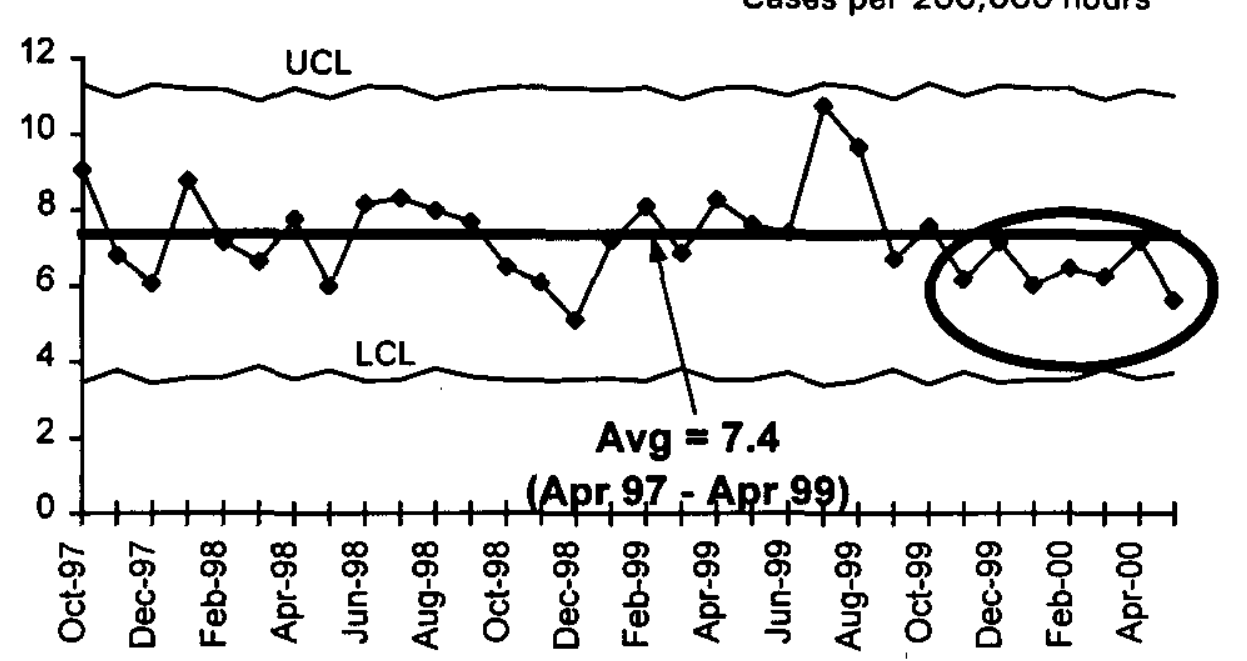

First Aid Rate undergoes seasonal cycles. Increases occur in warmer weather due to insect and animal encounters, and due to wind related minor injuries. First Aid cases rate has remained relatively stable, a good check that injuries are not being under-reported. There is currently 7 months in a row below average, due to the normal winter decrease. 


\section{DOE Safety Cost Index}

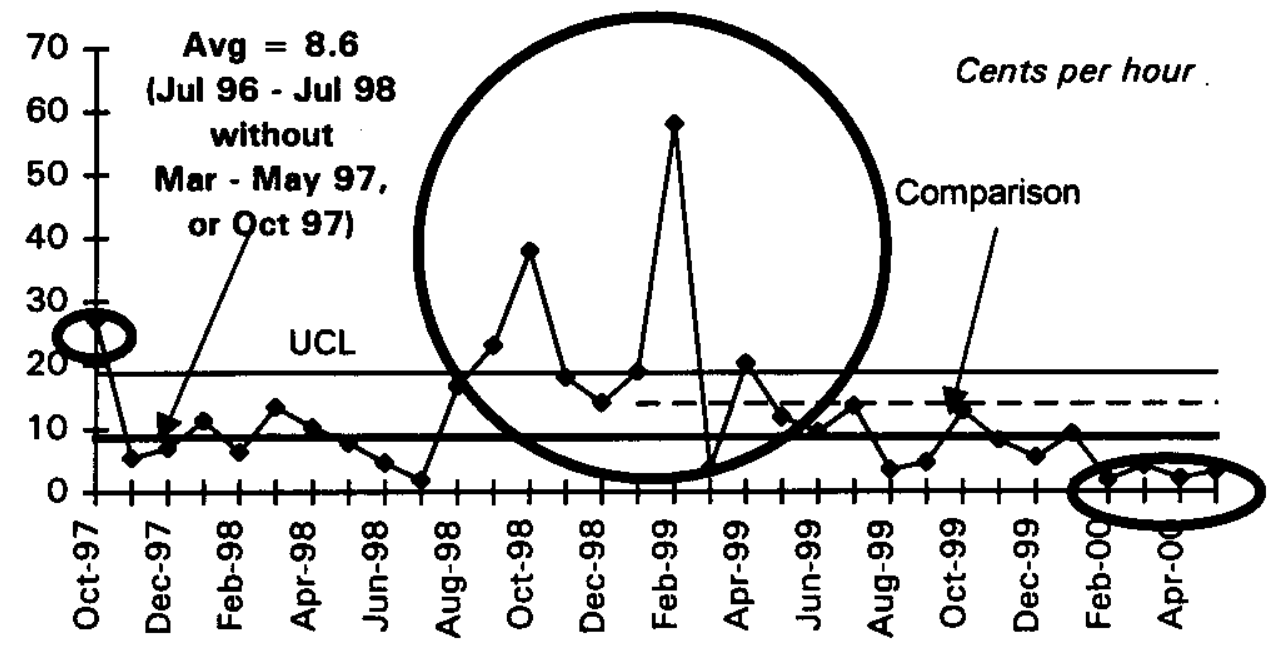

FY $1999=17$

FY 2000 to date $=5.7$

Contractor Comparison

Average $=13.9$ (CY99)

There has been a long term cycle over the past three years of decreases for 7 to 9 months, followed by increases. The past four months have been one standard deviation below average. However, recent data may gain further lost or restricted days.

\section{Critical TeChNiCAL ISSUES}

Nothing to report. 


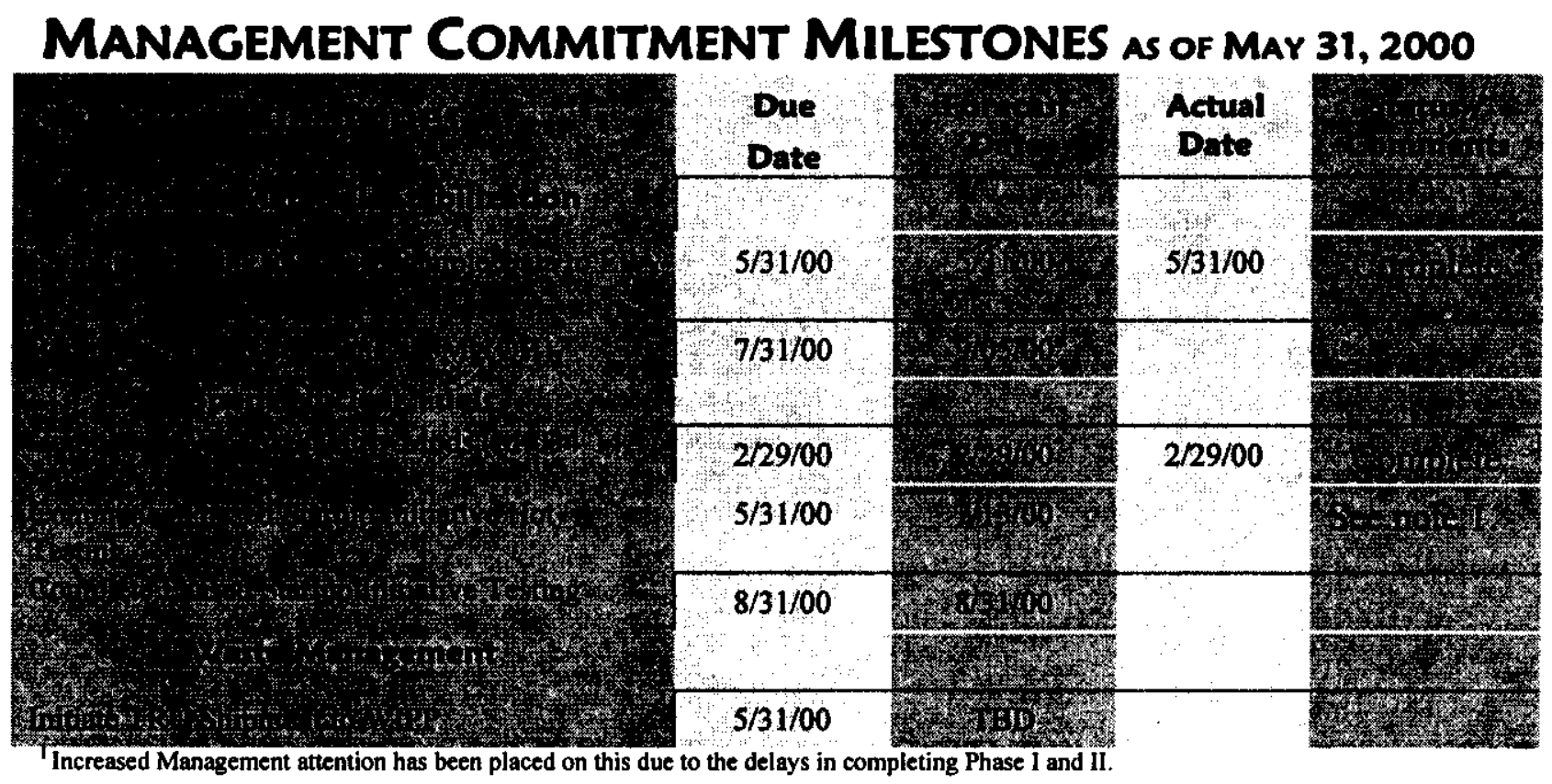

\section{Critical few Performance Measures}

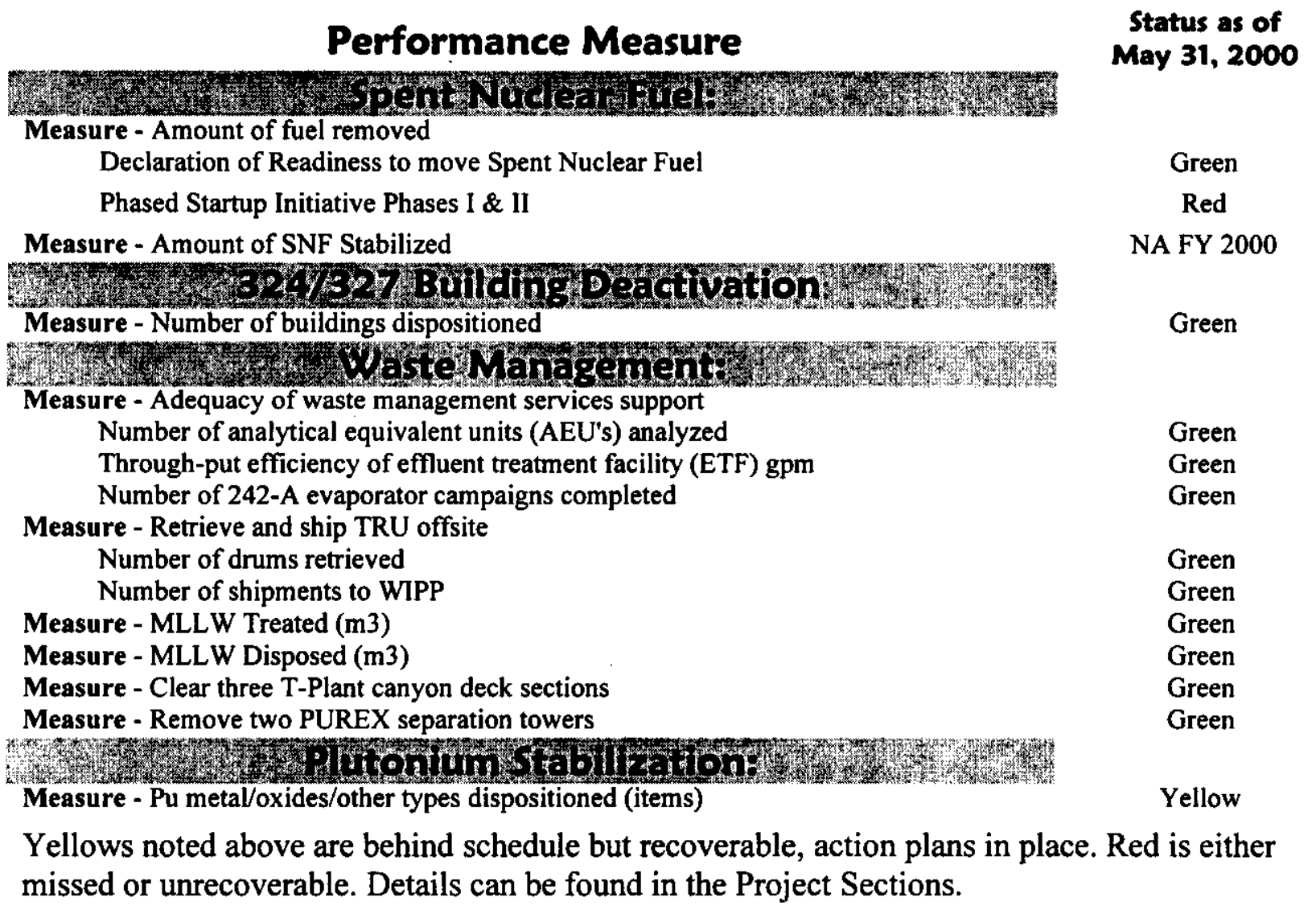




\section{KEY INTEGRATION ACTIVITIES}

7 he following are the key technical integration activities that are currently underway and cross project/contractor lines. These activities are being addressed by inter-discipline and interproject groups and demonstrate that Hanford Site contractors are working together to accomplish the EM Clean up mission.

- Spent nuclear fuel (SNF) final disposition interface activities, including Office of Civilian Radiation Waste Management (OCRWM) Quality Assurance (QA) Program implementation, ongoing with National SNF Program.

- SNF Project fuel removal acceptance criteria and conceptual design reviews for 324 Building (B Cell) ongoing with River Corridor Project.

- K Basins sludge removal and Shippingport (PA) Pressurized Water Reactor Core 2 SNF removal implementation activities ongoing with Waste Management Project.

- WM continues working with DOE-RL, DOE-HQ and other Sites to develop and define Hanford's role in disposing of waste from other sites. Hanford's role as one of the identified LLW/MLLW disposal sites for the Complex is yet to be fully defined.

- WM continues working with PNNL, EM-50 and Mixed Waste Focus Area (MWFA) to obtain funding in support of mixed waste processing.

- Nuclear Material Stabilization Project continues working with PNNL on activities associated with the $\mathrm{Mg}(\mathrm{OH})_{2}$ process in order to accelerate the plutonium solution stabilization process, and polycube stabilization issues (gathering data for the SAR).

- Analytical Services continues to support BNFL efforts to establish required analytical support for glassification operations.

- In the longer term, BNFL could utilize unused space at WSCF for cold run test support and process laboratory analytical equipment testing.

- The 222-S laboratory, with some refurbishment might become a low cost option to a new large-scale laboratory associated with the glassification facility.

- A white paper is being prepared for RPP to address the potential support that 222-S and WSCF could provide to the glassification facility.

- Landlord Project is establishing a Hanford Site Planning Advisory Board made up of cooperating agencies and Tribal representatives to support implementation of the Comprehensive Land Use Plan (CLUP).

- Landlord Project is developing and administering Real Estate documents (e.g., licenses, leases, easements, and permits). 


\section{Upcoming Planned Key Events}

The following Key events are extracted from the authorized baseline and are currently expected to be accomplished during the next eight months. Most are Enforceable Agreement (EA), HQ or DNFSB Milestones.

\section{Waste Management:}

- Complete Waste Isolation Pilot Project (WIPP) Certification of Hanford's Transuranic (TRU) Project and initiate TRU shipments in FY2000.

- Treat 1,160 cubic meters (includes 100 cubic meters stretch) of MLLW at ATG by August 2000; dispose of Land Disposal Restriction compliant waste by September 2000.

- Retrieve 425 drums of suspect TRU waste from the Low-Level Burial Grounds by September 2000.

- Accelerate Readiness to Receive Spent Nuclear Fuel K Basin Sludge.

- Clear three sections of the T Plant Canyon deck in FY 2000.

- Complete entire deck clearing by the end of FY 2001.

\section{Nuclear Materials Stabilization:}

- Begin Pu solution stabilization via $\mathrm{Mg}(\mathrm{OH})_{2}$ in the 4th quarter of FY 2000.

- $\quad$ Complete glovebox installation in July 2000.

- Complete ORR and training activities for stabilization activities in room 230-C in September 2000.

- Continue metal stabilization processing in November 2000.

- Initiate polycube stabilization in 1st quarter of FY 2001.

River Corridor Project:

- Complete ISMS verification of Phase II readiness activities by June 2000 .

- Complete all B Plant closeout activities by July 28, 2000.

- Issue the final report for the 300 Area Waste Acid Treatment System (WATS) Resource Conservation and Recovery Act (RCRA) Closure Activities by September 2000.

- Complete Removal of 324 Building Radiochemical Engineering Cell (REC) B Cell Mixed Waste (MW) and Equipment by November 2000.

\section{Spent Nuclear Fuels:}

- Deliver eight more Multi-Canister Overpacks (MCO) by the end of June 2000.

- Complete Cask Loadout System (CLS) startup testing by the end of June 2000.

- Complete integrated subsystem testing of the Cold Vacuum Drying facility by the end of July.

- Begin DOE Operational Readiness Review (ORR) for fuel removal by mid-September 2000.

- Begin K West Basin fuel removal, drying \& storage operations by November 30, 2000.

\section{Landlord}

- Complete Project L-292, Emergency Preparedness Control Station (EPCS) in July 2000. This project retrofits the $100 \mathrm{~K} / \mathrm{D}$ Sirens to the new control system and changes the frequency for all the outdoor Site sirens so they can be controlled from a central point.

- Complete Project L-312, "2101M, MO-235, and Associated Buildings Storm Drainage Resolution" in July 2000. 

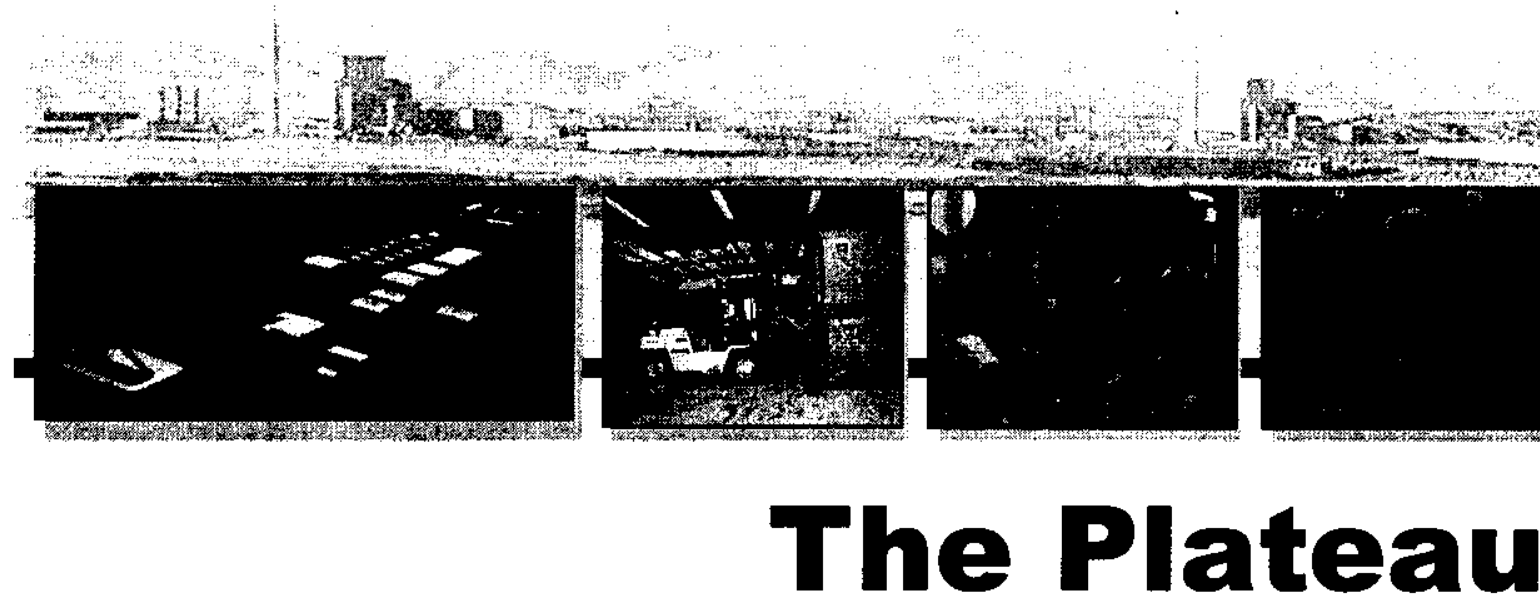

Transitioning the central plateau for long-term waste management is a key part of the Hanford vision. Determining the disposition of the "canyon" facilities, deactivating the Plutonium Finishing Plant and disposing of solid waste are the desired outcomes. Projects included in The Plateau are Waste Management, Analytical Services, and Nuclear Material Stabilization. 


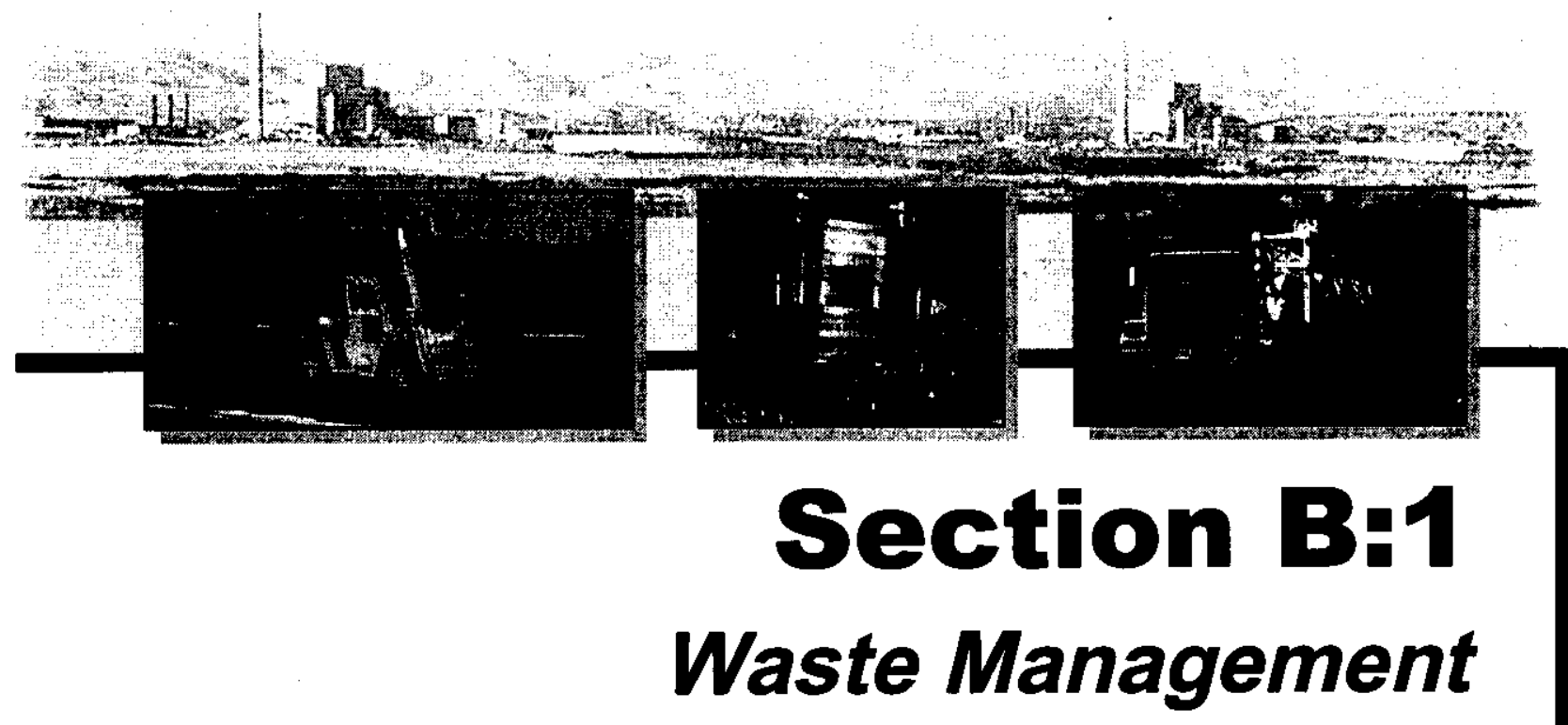

PROJECT MANAGERS

G.H. Sanders, RL (509) $376-6888$

E.S. Aromi Jr., WMH

(509) $372-1033$ 


\section{SUMMARY}

Waste Management consists of the Solid Waste Storage and Disposal, Project Baseline Summary (PBS) WM03, Work Breakdown Structure (WBS) 1.2.1; Solid Waste Treatment, PBS WM04, WBS 1.2.2; Liquid Effluents - 200 Area, PBS WM05, WBS 1.2.3.1; and the Waste Encapsulation and Storage Facility, PBS TP02, WBS 1.4.2.

PBS WM05 is divided between WBS 1.2.3.1, Liquid Effluents (200 LEF) and WBS 1.2.3.2, 310 TEDF/340 Facility (300 LEF). The 310 TEDF/340 Facility work scope is now included in the River Corridor Project, whereas the Liquid Effluents (200 LEF) work scope has remained in Waste Management. For the purpose of performance analysis, PBS WM05 is reported in its entirety in the Waste Management Project, which has the majority of the work scope and funding.

NOTE: Unless otherwise noted, the Safety, Conduct of Operations, Milestone Achievement, and Cost/Schedule data contained herein is as of May 31, 2000. Other information is updated as noted.

Fiscal-year-to-date milestone performance (EA, DOE-HQ and RL) shows that one milestone (100 percent) was completed on or ahead of schedule. Overall Project performance continues to be excellent. Cost and schedule goals are on track to be met.

\section{ACCOMPLISHMENTS}

- $\quad$ The first Transuranic packaging transporter (TRUPACT II) shipping container has been loaded and leak tested. Thirty-three drums have been loaded for shipment in three TRUPACT II shipping containers. The TRUPACT IIs will remain loaded and "ready for shipment" pending resolution of the New Mexico Environment Department issues.

- $\quad$ Shipped 708 containers totaling 990 cubic meters of mixed low-level waste to Allied Technology Group, Inc. (ATG), which represents $85 \%$ of the FY 2000 target. This waste volume represents an effective Central Waste Complex (CWC) storage volume reduction of 1,670 cubic meters. ATG has treated 186 containers totaling 569 cubic meters of waste, which represents $49 \%$ of the FY 2000 treatment target. Hanford has accepted back for disposal, 114 containers totaling 300 cubic meters, which represents $43.2 \%$ of the FY 2000 disposal target. (All data projected to June 16, 2000.)

- Completed nondestructive examination on 590 drums, radiography on 27 boxes, nondestructive assays of 563 drums, processing of 29 drums through the Low Level Waste repackaging/compaction glovebox, visual examinations of 25 TRU drums and repackaged 14 Waste Isolation Pilot Plant TRU drums in the TRU glovebox at the Waste Receiving and Processing (WRAP) facility through June 8, 2000. (Performance during current period on plan.) 
- $\quad$ Process feed to the 242A Evaporator was completed on May 2, 2000 and flushing of the evaporator completed on May 5. The campaign processed 1.3 million gallons of highlevel radioactive waste with an all-time high operational efficiency of $99.3 \%$. Processed 11.9 million gallons of wastewater through the 200 Effluent Treatment Facility (through June 16, 2000) supporting River Protection Project (RPP), Environmental Restoration Contract (ERC) 200-UP-1 Groundwater, N-Basin Water, Mixed Waste Trench Leachate, and Environmental Restoration Disposal Facility (ERDF) Leachate.

- The Hanford Mixed Waste Management Program Implementation Plan for the Ecology final Determination on Land Disposal Restriction (LDR) was approved on June 12, 2000. This document contains a number of requirements for format and content changes to the annual LDR report as well as business conduct changes (e.g., storage compliance assessment program). A version of this "Hanford Site Mixed Waste Management Program Implementation Plan," a progress report that shows progress in implementing the plan, and an updated LDR report for 2000 , will be issued by July 31,2000 to the regulators to satisfy the requirements of TPA milestone M-26-01. Work is beginning on the progress report for the July 31,2000 deliverable.

\section{Safety}

The project's safety rates are stable. The WMP Safety Council has taken actions to work with the various project safety councils and management to review past events and identify corrective actions. 

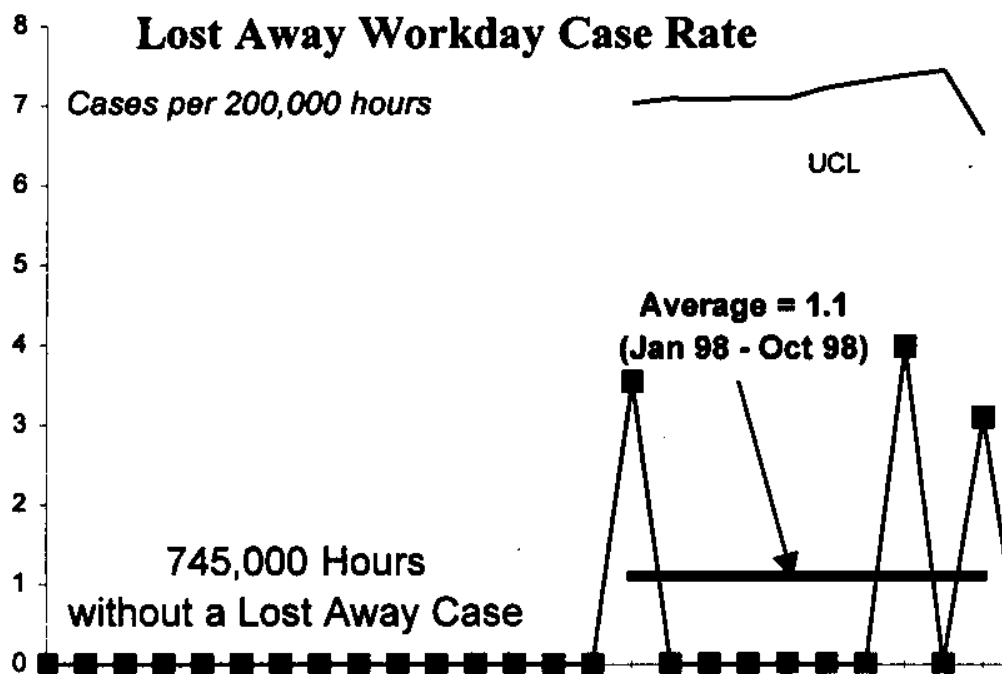

Project Safe Hours $=921,188$

FY $1999=0.24$

FY 2000 to date $=\mathbf{0 . 2 0}$

UCL

Average $=1.1$

(Jan 98 - Oct 98)

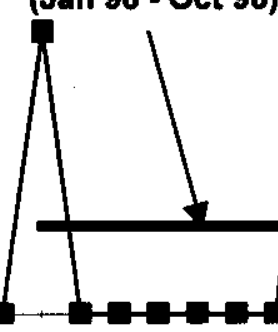

606,000 Hours

without a Lost Away Case

$20_{T}$ OSHA Recordable Case Rate
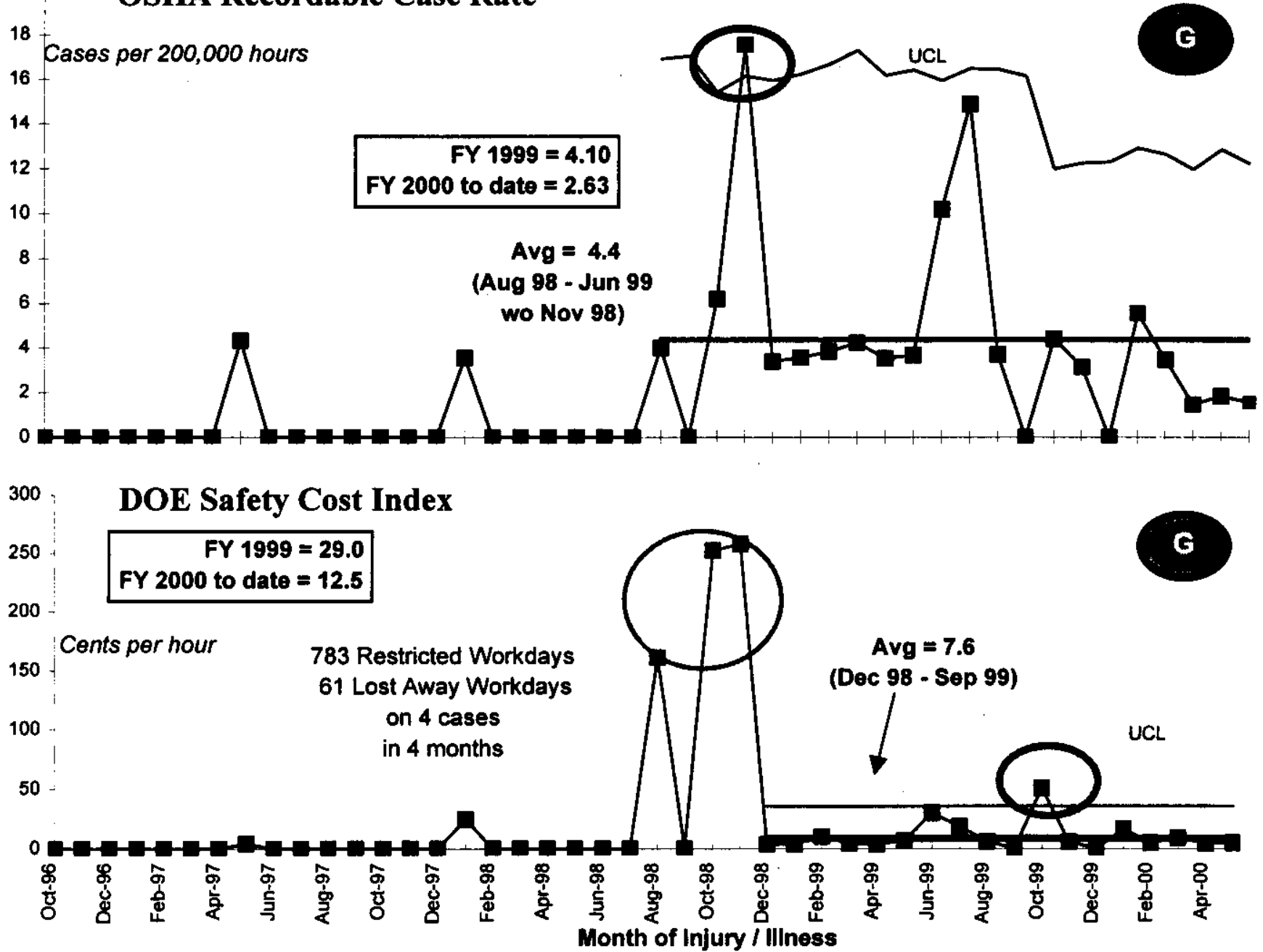


\section{CONDUCT OF OPERATIONS / ISMS STATUS CONDUCT OF OPERATIONS Events per 200,000 hours}

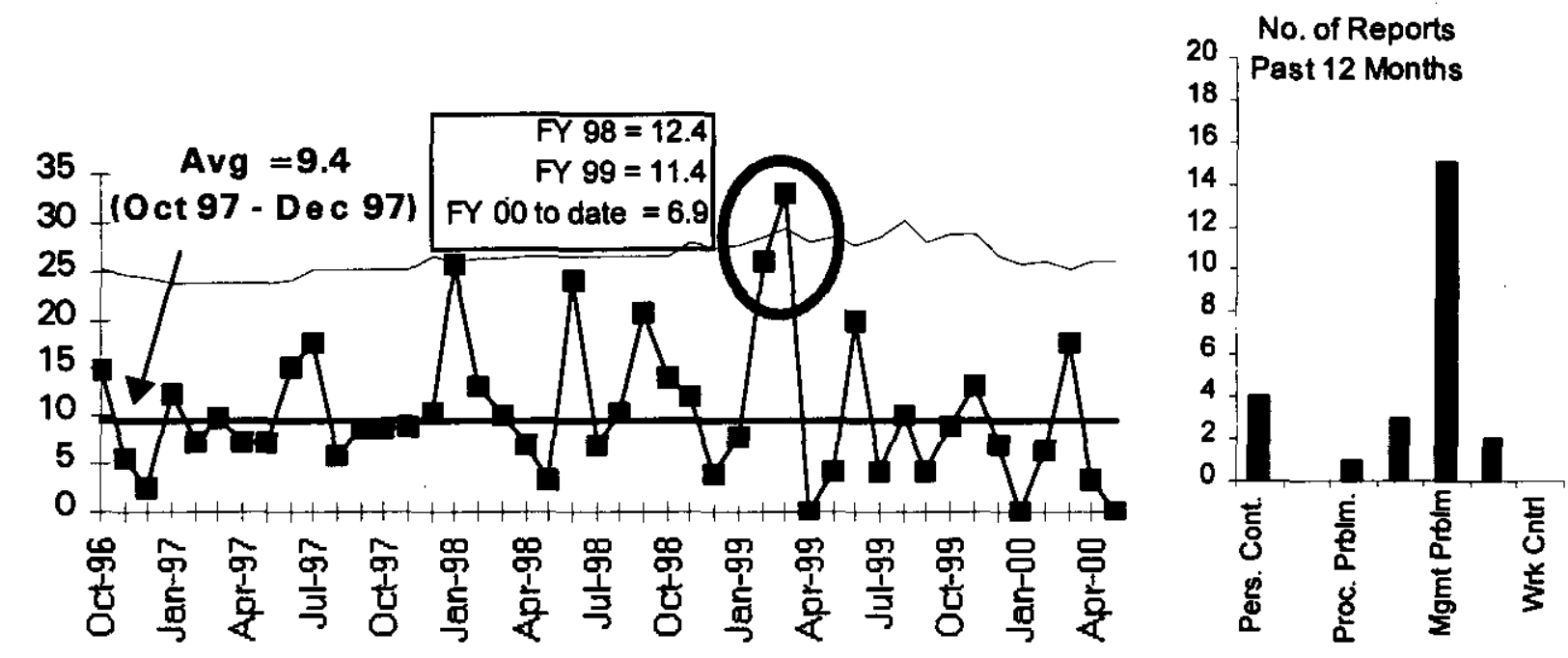

ISMS STATUS

\section{Completed Activities:}

- The DOE ISMS Phase I verification team completed their review, including interviewing of individual employees against a set of CRADS (Criteria and Review Approach Document). All CRAD objectives were met. Several Noteworthy Practices were found, as well as Opportunities for Improvement.

- The final Session Four Training, "ISMS Verification and Your Role" was completed on June 8, 2000. This training will help the activity level workforce prepare for Phase II verification. Authorization Agreements are approved.

- All 100 / 200 level administrative procedures that impact the WM/AS ISMS System Description have been revised to more closely reflect the FH MP-001.

- CRAD Books, which include crosswalks between the System Description and implementing mechanisms, were completed.

- $\quad$ SMART books for Phase II were developed for the DOE team members and those likely to be interviewed.

Planned Actions:

- Phase II verification is currently scheduled to begin June 12,2000 and will continue through approximately June 21, 2000.

- Generate and implement out-year plan to sustain and maintain ISMS effort. 


\section{BREAKTHROUGHS / OPPORTUNITIES FOR IMPROVEMENT}

The Waste Management Project is leading the "Waste and Materials Disposition" Team in the DOE RL 200 Area Options Study effort. This identification of potential flexibility in the activities will provide a basis for opportunities in refining baselines in the FY 2002-2016 timeframe.

\section{UPCOMING ACTIVITIES}

WIPP Certification and Waste Shipments - Complete Waste Isolation Pilot Project (WIPP) Certification of Hanford's Transuranic (TRU) Project and initiate TRU shipments to WIPP.

PMP for TRU \& TRUM Waste - Issue Project Management Plan (PMP) for TRU \& TRUM (Transuranic Mixed) Waste in June 2000 to meet M-91 milestone.

MLLW Treatment - Treat 1,160 cubic meters (includes 100 cubic meters stretch) of Mixed Low-Level Waste (MLLW) at Allied Technology Group (ATG) by August 2000; dispose of the Land Disposal Restriction compliant waste by September 2000.

Suspect TRU Waste Retrieval - Retrieve 425 drums of suspect TRU waste from the LowLevel Burial Grounds by September 2000.

Accelerate Readiness to Receive Spent Nuclear Fuel K Basin Sludge - Clear three sections of the T Plant Canyon deck in FY 2000 and complete entire deck clearing by FY 2001. Complete Project Execution Plan and Conceptual Design Documents for removal of Shippingport Fuel from T Plant in FY 2000.

Land Disposal Restriction Report - Issue the year 2000 LDR Report by July 31, 2000.

\section{Cost Performance $(\$ M):$}

\begin{tabular}{|l|c|c|c|}
\hline & BCWP & ACWP & VARIANCE \\
\hline Waste Management & $\$ 67.3$ & $\$ 67.9$ & $-\$ 0.6$ \\
\hline
\end{tabular}

The $\$ 0.6 \mathrm{M}$ (1 percent) unfavorable cost variance is within the established threshold. Further information at the PBS level can be found in the following Cost Variance Analysis details.

\section{Schedule Performance (\$M):}

\begin{tabular}{|l|c|c|c|}
\hline & BCWP & BCWS & VARIANCE \\
\hline Waste Management & $\$ 67.3$ & $\$ 69.4$ & $-\$ 2.2$ \\
\hline
\end{tabular}

The $\$ 2.2$ million ( 3 percent) unfavorable schedule variance is within established threshold. Further information at the PBS level can be found in the following Schedule Variance Analysis details. 


\section{FY 2000 Cost/SChedule Performance - All Fund TyPes Cumulative to Date Status - $(\$ 000)$}

\begin{tabular}{|c|c|c|c|c|c|c|c|c|c|c|c|c|c|c|c|c|c|c|c|}
\hline & & & & & & & & & & & & & & & & & & & \\
\hline & By PBS & & BCW/s & & BCWP & & ACWP & & $\mathbf{s V}$ & $\%$ & & CV & $\%$ & & PEM & $\mathbf{F Y}$ & & EA & \\
\hline $\begin{array}{l}\text { PBS WM03 } \\
\text { WBS } 1.2 .1\end{array}$ & $\begin{array}{l}\text { Solid Waste Storage \& } \\
\text { Disposal }\end{array}$ & $s$ & 22,675 & $\mathbf{s}$ & 22,158 & $\$$ & 22,276 & $\$$ & (516) & $-2 \%$ & $\mathbf{s}$ & (118) & $-1 \%$ & $\boldsymbol{s}$ & 34,323 & $\mathbf{s}$ & 34,269 & $\mathbf{S}$ & 34,269 \\
\hline $\begin{array}{l}\text { PBS WM04 } \\
\text { WBS } 1.2 .2\end{array}$ & Solid Waste Treatment & $\$$ & 19,746 & $\mathbf{s}$ & 19,606 & $\mathbf{s}$ & 20,804 & $\$$ & $(140)$ & $-1 \%$ & $\$$ & $(1,198)$ & $-6 \%$ & $\mathbf{s}$ & 30,766 & $\mathbf{s}$ & 35,074 & $\mathbf{s}$ & 35,074 \\
\hline $\begin{array}{l}\text { PBS WM05* } \\
\text { WBS } 1.2 .3\end{array}$ & $\begin{array}{l}\text { Liquid Effluents - } \\
200 / 300 \text { Area }\end{array}$ & $\$$ & 18,684 & $\$$ & 17,585 & $\mathbf{s}$ & 16.677 & $\mathbf{S}$ & $(1,119)$ & $-6 \%$ & $\mathbf{S}$ & 888 & $5 \%$ & $\$$ & 29,326 & $\$$ & 26,649 & 5 & 26,649 \\
\hline $\begin{array}{l}\text { PBS TP02 } \\
\text { WBS } 1.4 .2\end{array}$ & WESF & $\$$ & 8,326 & $\$$ & 7,829 & $\mathbf{s}$ & 8,138 & $\$$ & $(397)$ & $-5 \%$ & $\mathbf{s}$ & (208) & $-3 \%$ & $\$$ & 12,708 & $\$$ & 12,197 & $\$$ & 12,197 \\
\hline & Total & $\mathbf{s}$ & 69,431 & $\$$ & 67,259 & $s$ & 67,895 & $s$ & $(2,172)$ & $-3 \%$ & $s$ & (636) & $-1 \%$ & $\mathbf{s}$ & 107,123 & $\mathbf{s}$ & 108,189 & $\mathbf{S}$ & 108,189 \\
\hline
\end{tabular}

- PBS WM05 includes the 300 Area Liquid Effluent, which is part of the River Corridor Project.

- $\quad$ RL-Directed costs (steam and laundry) are included in the PEM BCWS.

\section{Cost/SChedule PerformanCe INDices (MONTHLY AND FYTD)}

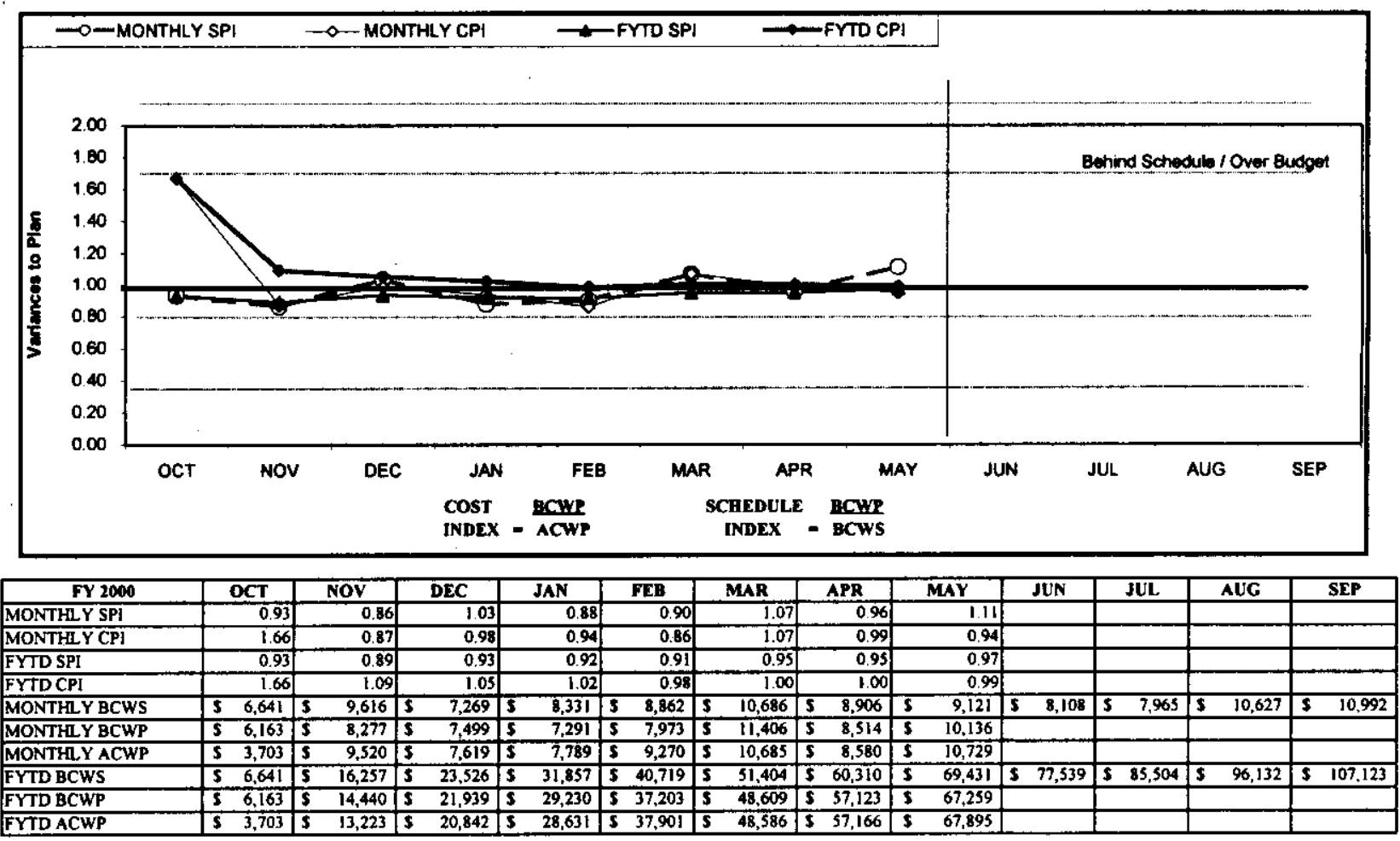




\section{COSt VARIANCE ANalysis: $(-\$ 0.6 \mathrm{M})$}

\section{WBS/PBS}

1.2.1/WM03

\section{Title}

\section{Solid Waste Storage \& Disposal}

Description/Cause: The unfavorable cost variance of $\$ 0.1 \mathrm{M}(1$ percent) is within the established threshold.

Impact: No impact.

Corrective Action: No action required.

\subsection{2/WM04 Solid Waste Treatment}

Description/Cause: The unfavorable cost variance of $\$ 1.2 \mathrm{M}(6$ percent) is due to Canyon Deck Clean Off workscope being performed under an Advanced Work Authorization (AWA) for T Plant support to accelerated SNF sludge removal. In addition, there are retooling and TRU project recertification costs caused by the new WIPP permit changes. Installation of the 2706-T greenhouse to support production and additional minimum safe maintenance activities also contributed to the variance.

Impact: No impact.

Corrective Action: A BCR for the T Plant was approved on $6 / 1$ and will be implemented in the June baseline. A BCR for the TRU Project additional workscope has been submitted.

\subsubsection{1/WM05 Liquid Effluents}

Description/Cause: The favorable cost variance of $\$ 0.9 \mathrm{M}(6$ percent) is within the established threshold.

Impact: No impact.

Corrective Action: No corrective action required.

\subsection{2/TP02}

WESF

Description/Cause: The unfavorable cost variance of $\$ 0.2 \mathrm{M}(3$ percent) is within the established threshold.

Impact: No impact.

Corrective Action: No corrective action required.

\section{SChedule Variance ANAlysis: (- \$2.2M)}

\section{WBS/PBS}

1.2.1/ WM03

\section{Title}

\section{Solid Waste Storage \& Disposal}

Description /Cause: The unfavorable schedule variance of $\$ 0.5 \mathrm{M}$ ( 2 percent) is within the established threshold.

Impact: No Impact.

Corrective Action: No corrective action required. 


\subsection{2/ WM04}

Solid Waste Treatment

Description /Cause: The unfavorable schedule variance of $\$ 0.1 \mathrm{M}$ (1 percent) is within the established threshold.

Impact: No Impact.

Corrective Action: No corrective action required.

\subsubsection{1/ WM05}

Liquid Effluents

Description /Cause: The unfavorable schedule variance of $\$ 1.1 \mathrm{M}$ (6 percent) is within the established threshold.

Impact: No Impact.

Corrective Action: No corrective action required.

\subsection{2/ TP02 WESF}

Description /Cause: The unfavorable schedule variance of $\$ 0.4 \mathrm{M}$ (5 percent) is within the established threshold.

Impact: No Impact.

Corrective Action: No corrective action required.

\section{ISSUES}

\section{Technical Issues}

Nothing to report at this time.

\section{DOE/Regulator/External Issues}

The Waste Management Programmatic Environmental Impact Statement (PEIS) was issued on February 25, 2000. These Records of Decision (ROD) for LLW and MLLW will affect Hanford's disposal role for the Complex and the ROD outcomes may have a significant impact on disposal volumes and rates at Hanford. DOE-HQ and WDOE negotiations continue; impacts depend upon results of these negotiations.

Certification of Hanford's TRU Project is necessary to initiate waste shipment to WIPP. Continue working with the Carlsbad Area Office, the Environmental Protection Agency (EPA) and the New Mexico Environment Department (NMED) to achieve WIPP certification of Hanford's TRU Project and initiate waste shipment to WIPP.

Ecology issued a Final Determination (FD) regarding the "recent" dispute over the scope of the annual Land. The Hanford Mixed Waste Management Program Implementation Plan for the Ecology Final Determination on LDR was approved on June 13, 2000. This document contains a number of requirements for format and content changes to the annual LDR report as well as business conduct changes (e.g., storage compliance assessment program). A version of this "Hanford Site Mixed Waste Management Program Implementation Plan," a progress report 
that shows progress in implementing the plan, and an updated LDR report for 2000, will be issued by July 31,2000 to the regulators to satisfy the requirements of TPA milestone M-26-01.

\section{Baseline Change Requests Currently in Process (\$000)}

\begin{tabular}{|c|c|c|c|c|c|c|c|c|c|}
\hline $\begin{array}{l}\text { PROJECT } \\
\text { CHANGE } \\
\text { NUMBER } \\
\end{array}$ & $\begin{array}{c}\text { DATE } \\
\text { ORIGIN. } \\
\end{array}$ & BCR TITLE & $\begin{array}{c}\text { FY00 COST } \\
\text { IMPACT } \\
\text { S000 }\end{array}$ & SCH & TECH & $\begin{array}{c}\text { DATE } \\
\text { TO CCB } \\
\end{array}$ & $\begin{array}{c}\text { CCB } \\
\text { APR'VD } \\
\end{array}$ & $\begin{array}{c}\mathbf{R L} \\
\mathbf{A P R} \mathbf{V D} \\
\end{array}$ & $\begin{array}{l}\text { CURRENT } \\
\text { STATUS } \\
\end{array}$ \\
\hline WM-2000-003 & $2 / 8 / 00$ & $\begin{array}{l}\text { T-Plant Canyon Deck Clean off and } \\
\text { PWR Fuel Removal }\end{array}$ & \$ 3,085 & & & $4 / 13 / 200$ & $04 / 13 / 00$ & $06 / 01 / 00$ & $\begin{array}{l}\text { To be } \\
\text { implemented in } \\
\text { June Baseline }\end{array}$ \\
\hline WM-2000-004 & $2 / 8 / 00$ & WMP Stretch Goals & S 1,250 & & & $05 / 31 / 00$ & $05 / 31 / 00$ & & At DOE-RL \\
\hline WM-2000-006 & $3 / 21 / 00$ & TRU Project Rebaselining & s - & & & $06 / 08 / 00$ & $06 / 08 / 00$ & & At DOE-RL \\
\hline WM-2000-008 & $4 / 13 / 00$ & LDR & S 415 & & & TBD & & & Draft \\
\hline WM-2000-009 & $4 / 13 / 00$ & 616 Transition & $\$ \quad 87$ & & & N/A & N/A & N/A & $\begin{array}{l}\text { Approved by } \\
\text { Project Director } \\
6 / 2 / 00\end{array}$ \\
\hline WM-2000-011 & $4 / 27 / 00$ & CSERS/Weed \& Pest Allocation & $\$ 963$ & & & $06 / 01 / 00$ & $06 / 01 / 00$ & N/A & $\begin{array}{l}\text { To be } \\
\text { implemented in } \\
\text { June Baseline }\end{array}$ \\
\hline \multicolumn{10}{|c|}{ ADVANCE WORK AUTHORIZATIONS } \\
\hline AWA & $6 / 1 / 00$ & TRU Retrieval/TRU PMP & 750 & & & & & $06 / 01 / 00$ & $\begin{array}{l}\text { Acceleration of } \\
\text { scope }\end{array}$ \\
\hline AWA & $5 / 8 / 00$ & LDR & $\$ \quad 165$ & & & & & $5 / 8 / 00$ & $\begin{array}{l}\text { Acceleration of } \\
\text { scope }\end{array}$ \\
\hline
\end{tabular}




\section{Milestone ACHIEVEMENT}

\begin{tabular}{|r|r|r|r|r|r|r|r|r|}
\hline & \multicolumn{4}{|c|}{ FISCAL YEAR-TO-DATE } & \multicolumn{2}{c|}{ REMAINING SCHEDULED } & \\
\cline { 2 - 9 } MIILESTONE TYPE & $\begin{array}{c}\text { Completed } \\
\text { Early }\end{array}$ & $\begin{array}{c}\text { Completed On } \\
\text { Schedule }\end{array}$ & $\begin{array}{c}\text { Completed } \\
\text { Late }\end{array}$ & Overdue & $\begin{array}{c}\text { Forecast } \\
\text { Early }\end{array}$ & $\begin{array}{c}\text { Forecast On } \\
\text { Schedule }\end{array}$ & $\begin{array}{c}\text { Forecast } \\
\text { Late }\end{array}$ & $\begin{array}{c}\text { TOTAL } \\
\text { FY 2000 }\end{array}$ \\
\hline Enforceable Agreement & 1 & 0 & 0 & 0 & 0 & 1 & 0 & 2 \\
\hline DOE-HQ & 0 & 0 & 0 & 0 & 0 & 0 & 0 & 0 \\
\hline RL & 0 & 0 & 0 & 0 & 0 & 9 & 0 & 9 \\
\hline Total Project & 1 & 0 & 0 & 0 & 0 & 10 & 0 & 11 \\
\hline
\end{tabular}

TriParty Agreement / EA Milestones

\begin{tabular}{|l|l|l|}
\hline \multicolumn{1}{|c|}{ Number } & \multicolumn{1}{|c|}{ Milestone Title } & \multicolumn{1}{c|}{ Status } \\
\hline $\begin{array}{l}\text { M-91-03 } \\
\text { (WMH-00- } \\
\text { 001) }\end{array}$ & $\begin{array}{l}\text { Issue TRU/TRUM } \\
\text { Waste PMP }\end{array}$ & due 06/30/00 - On schedule (stretch) \\
\hline $\begin{array}{l}\text { M-91-04 } \\
\text { (A2J-00-001) }\end{array}$ & $\begin{array}{l}\text { Complete Construction } \\
\text { of CH TRU/TRUM } \\
\text { Retrieval Facility }\end{array}$ & $\begin{array}{l}\text { due 09/29/00 - DOE-RL issued a letter to Ecology on February 29, } \\
\text { 2000 documenting closure of the TPA milestone as retrieval has been } \\
\text { initiated and is planned to continue, even without construction of } \\
\text { Project W-113 facilities. }\end{array}$ \\
\hline & & \\
\hline
\end{tabular}

DNFSB Commitments

\begin{tabular}{|l|l|l|}
\hline & Nothing to report. & \\
\hline & & \\
\hline
\end{tabular}

\section{MILESTONE EXCEPTION REPORT}

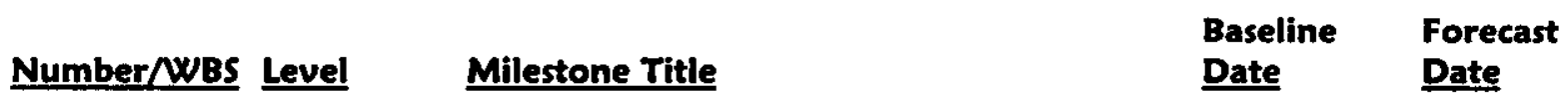

\section{OVERDUE - 0}

FORECAST LATE - 0

\section{FY 1999 OVERDUE - 1}

TRP-98-709 RL Complete Hot Cell Deactivation $\quad 03 / 31 / 99 \quad 09 / 30 / 00$

\subsubsection{WESF Facility (A-E)}

Cause: This milestone is not complete due to not being supported at the current funding level. Impact: No overall impact is expected.

Corrective Action: Return-on-Investment (ROI) funding has been identified for this work scope and a new forecasted completion date of September 30, 2000 established. 


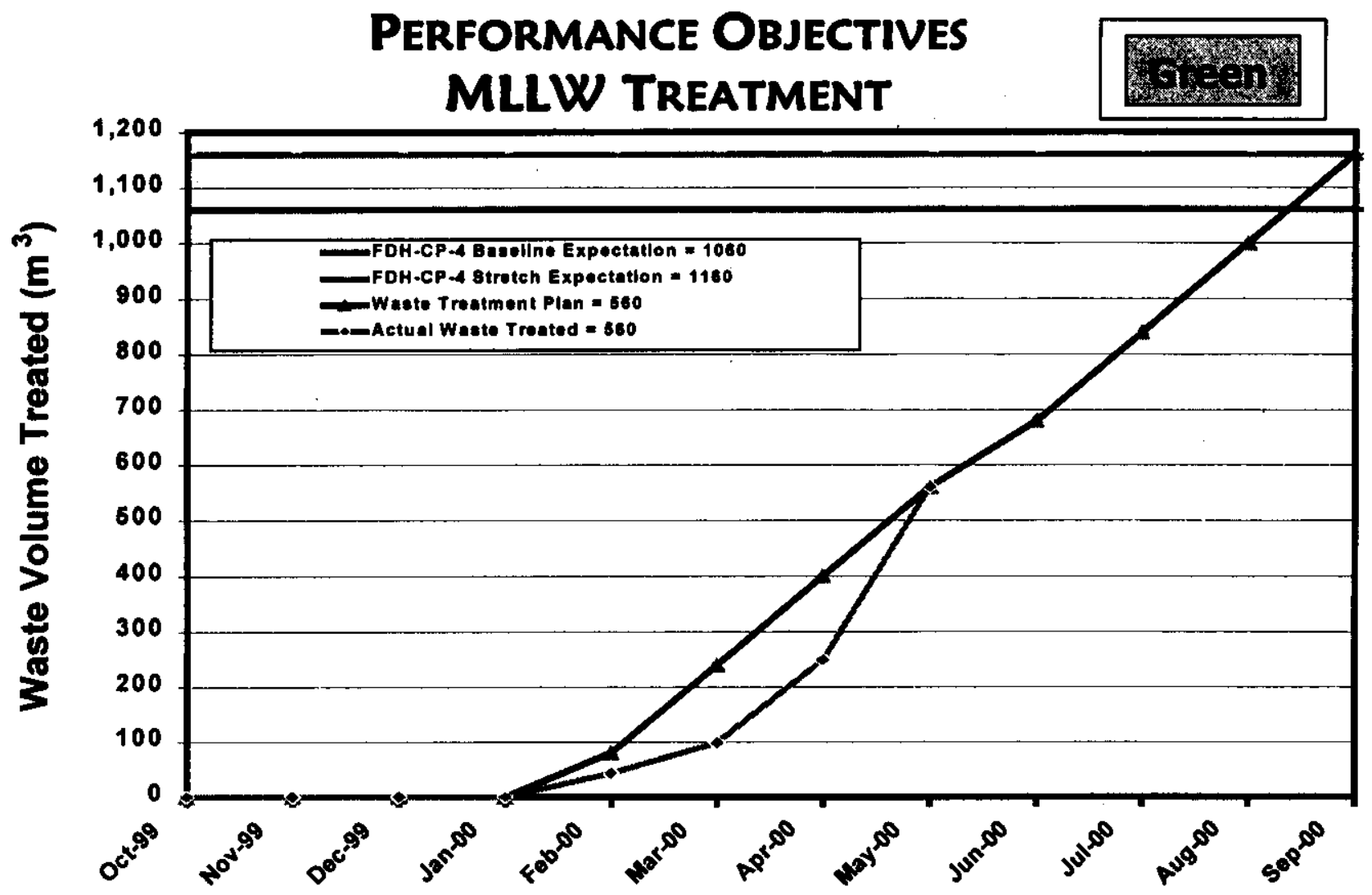

Action Plans: On track.

MLLW DISPOSAL

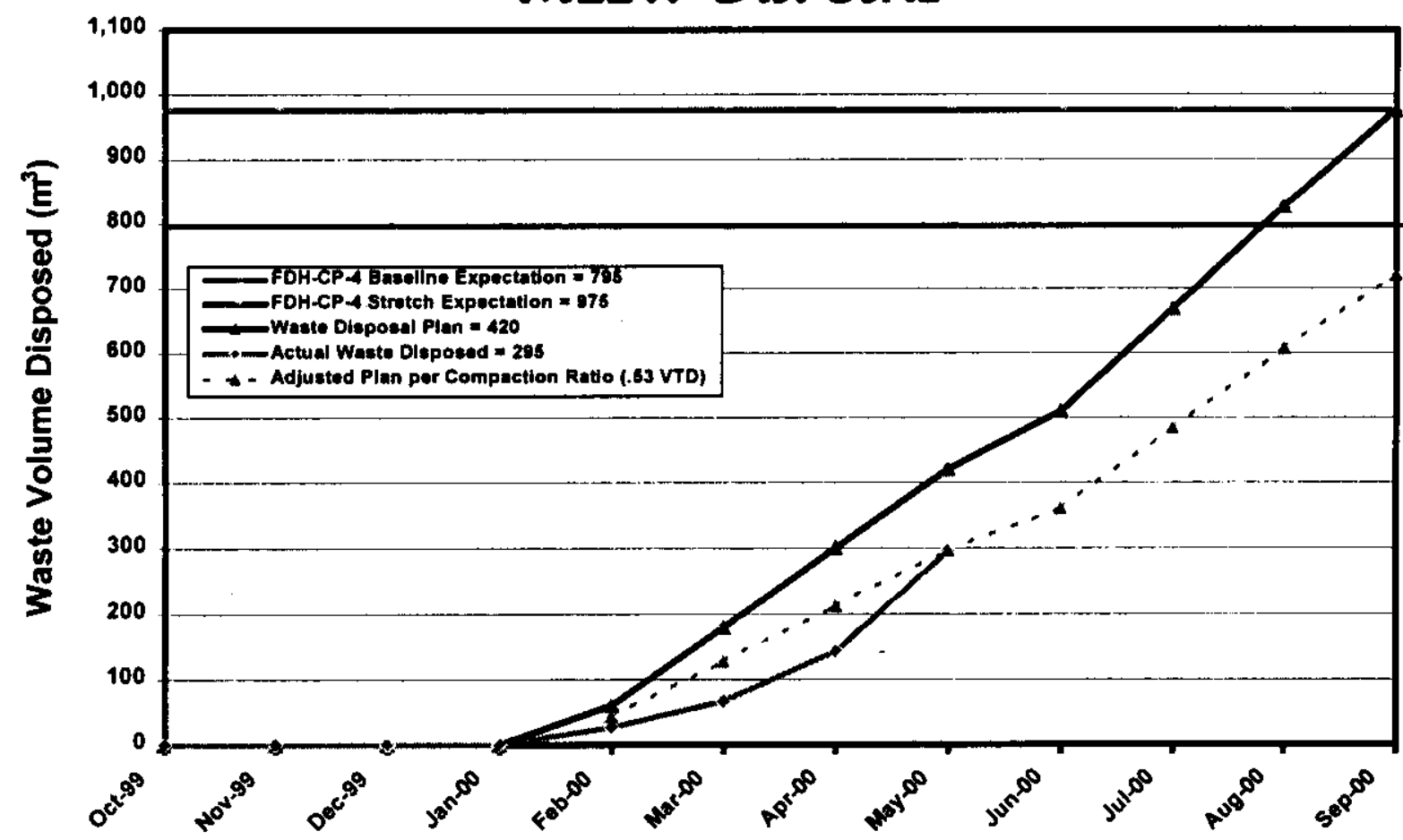

Action Plans: Ramping-up to meet stretch expectation. 
TRU RETRIEVAL

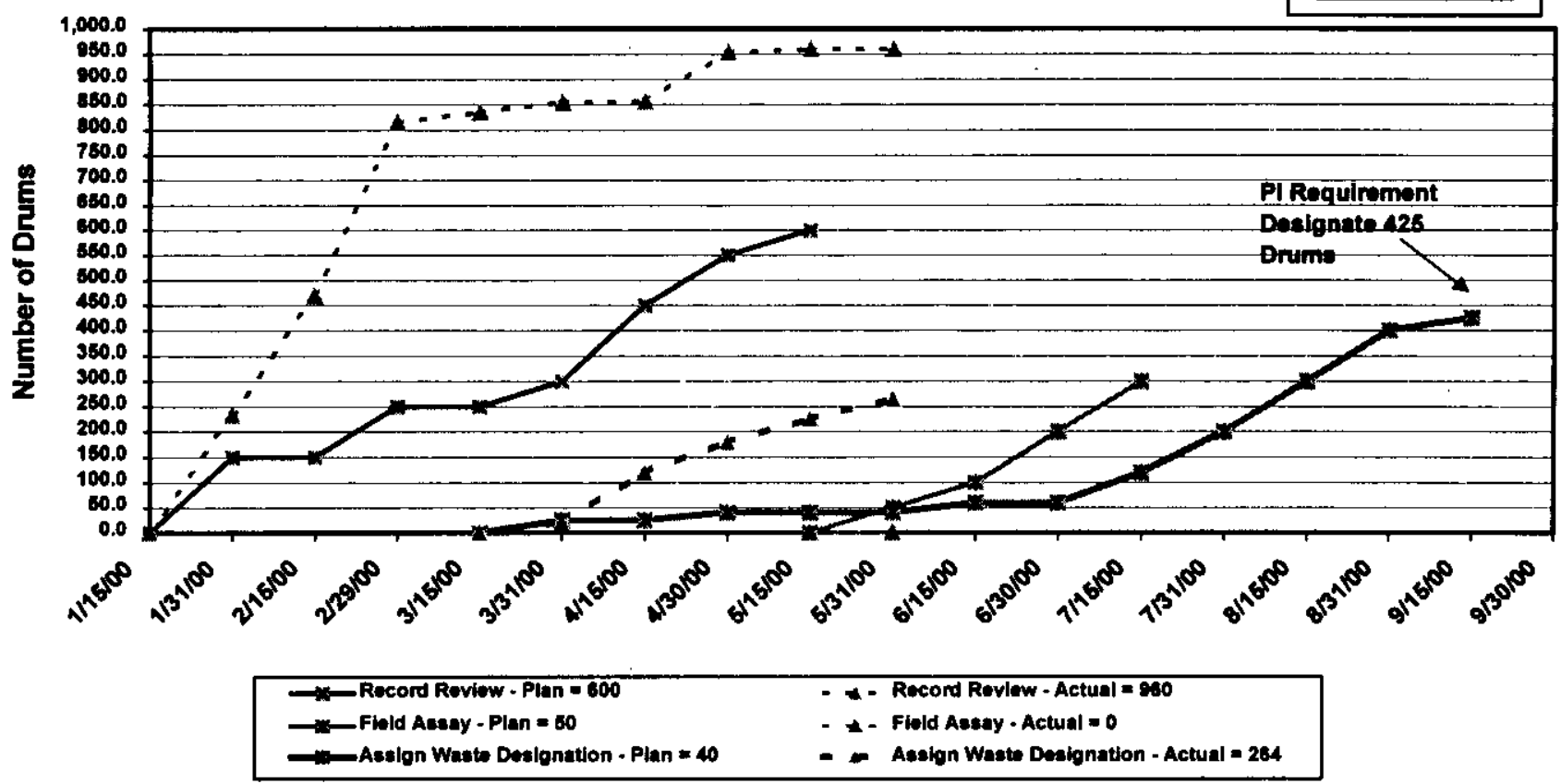

Action Plans: On track to meet the new stretch goal of 425 drums.

\section{Tru Container Processing}
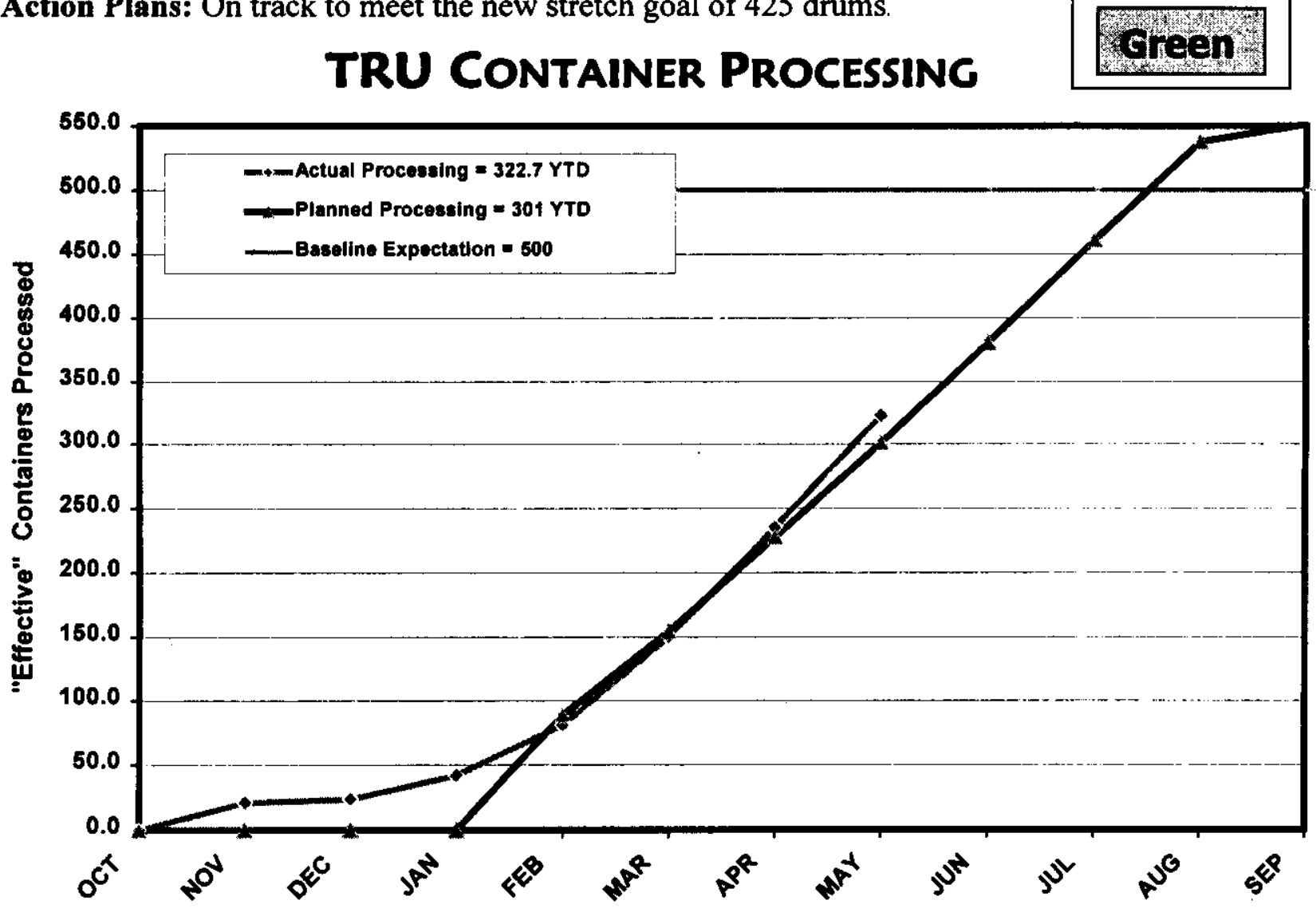

Action Plans: On track. 


\section{TRU Certification for SHIPPING}

\section{Yellow}

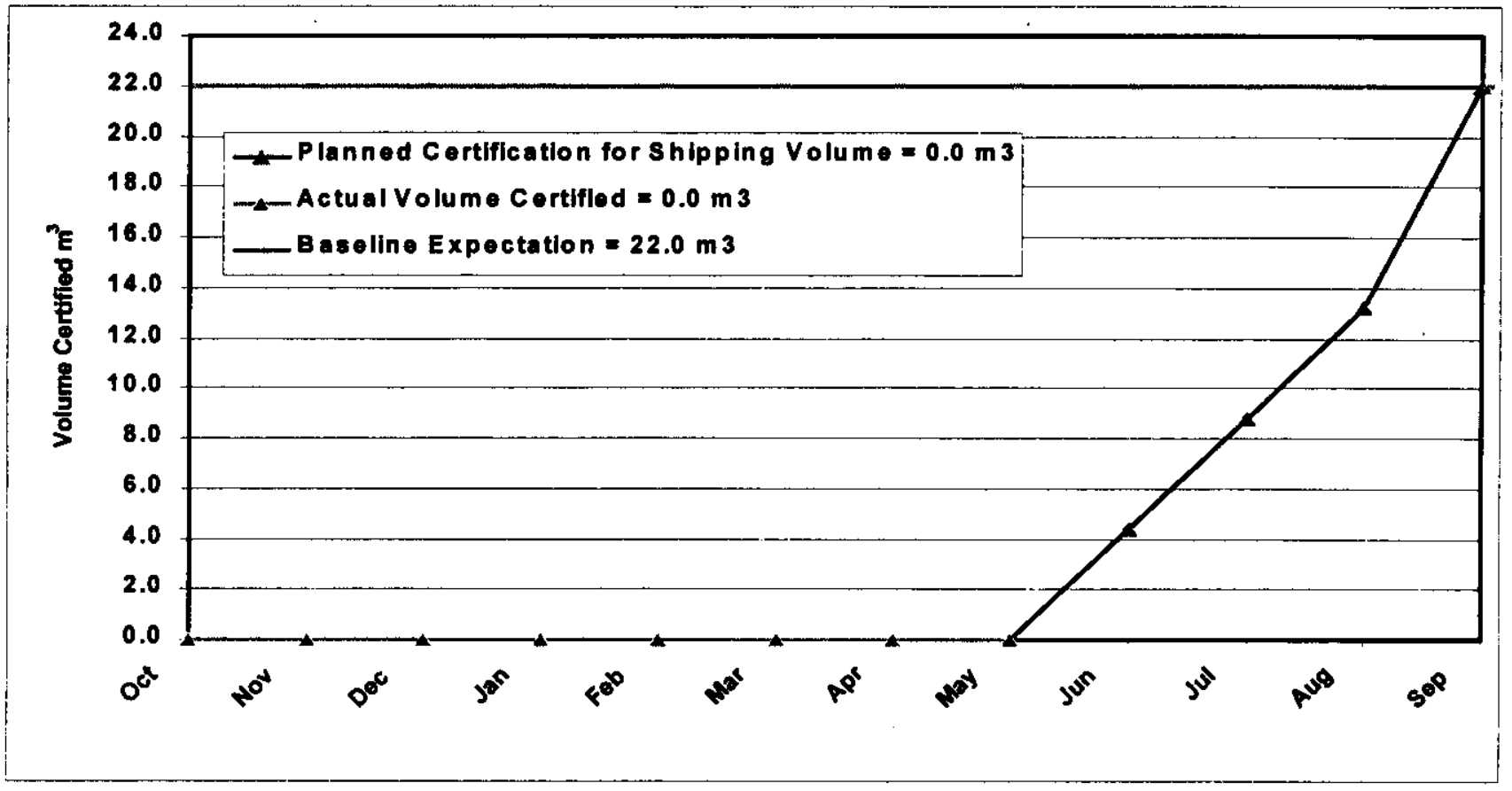

Action Plans: Initial shipment delayed beyond the planned June 19, 2000 date.

\section{LIRUID WASTE PROCESSING}

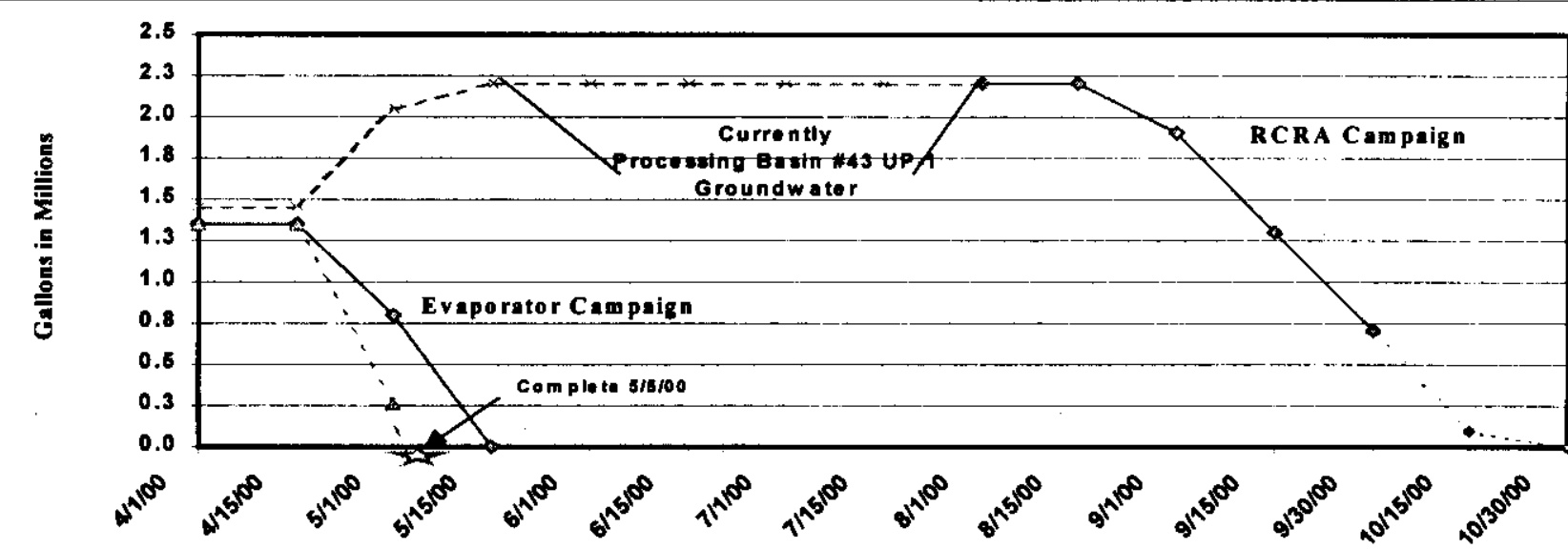

Action Plans: On track. The 242A Evaporator campaign was completed on May 2, 2000. The RCRA campaign scheduled to begin in mid-August 2000. A change agreement was completed and the PI revised in May 2000. 


\section{T Plant Deck Clearing (RC-4-1-1)}
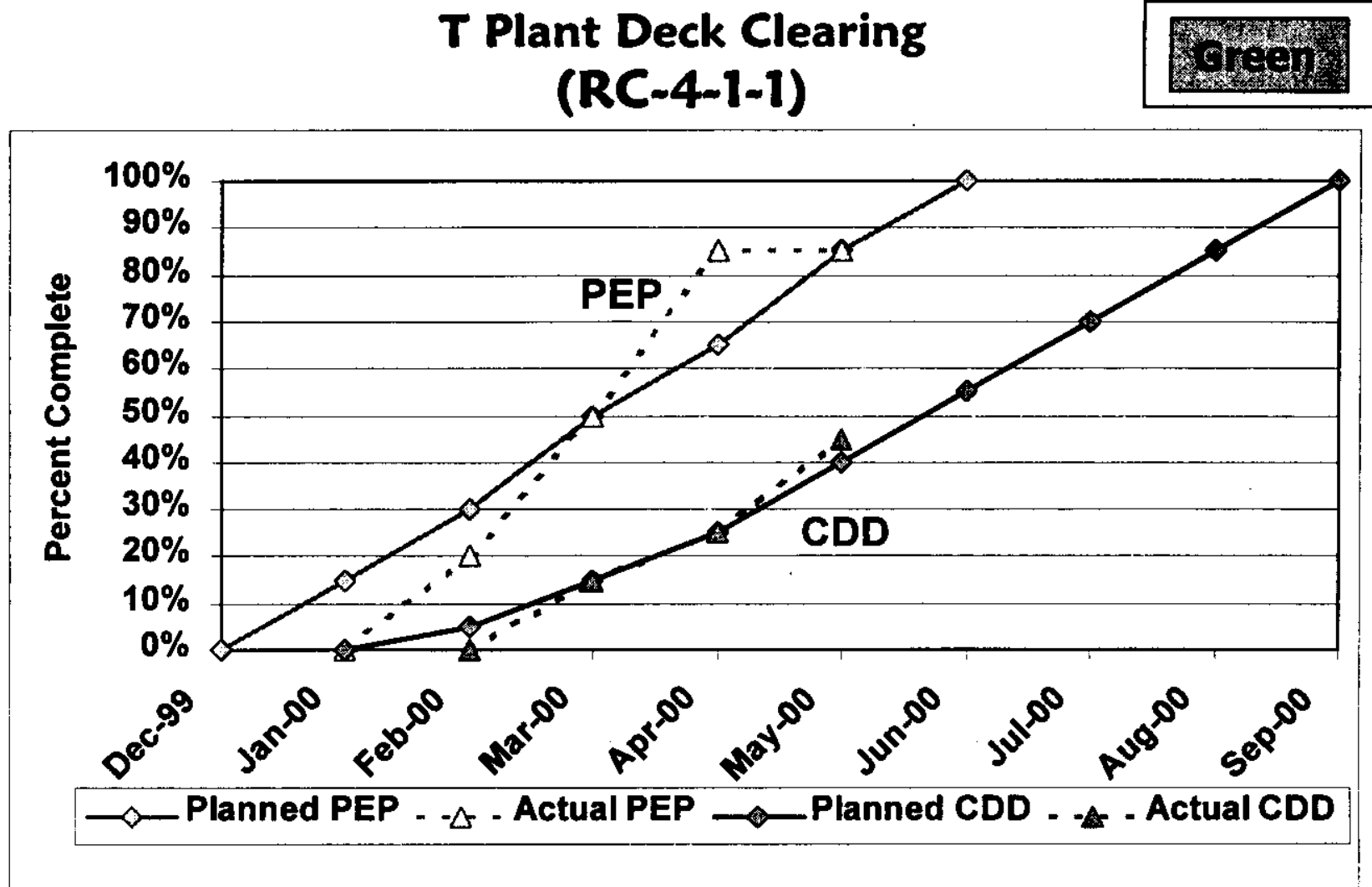

Action Plans: On track for completion in September 2000.

\section{T Plant PEP AND CDD}

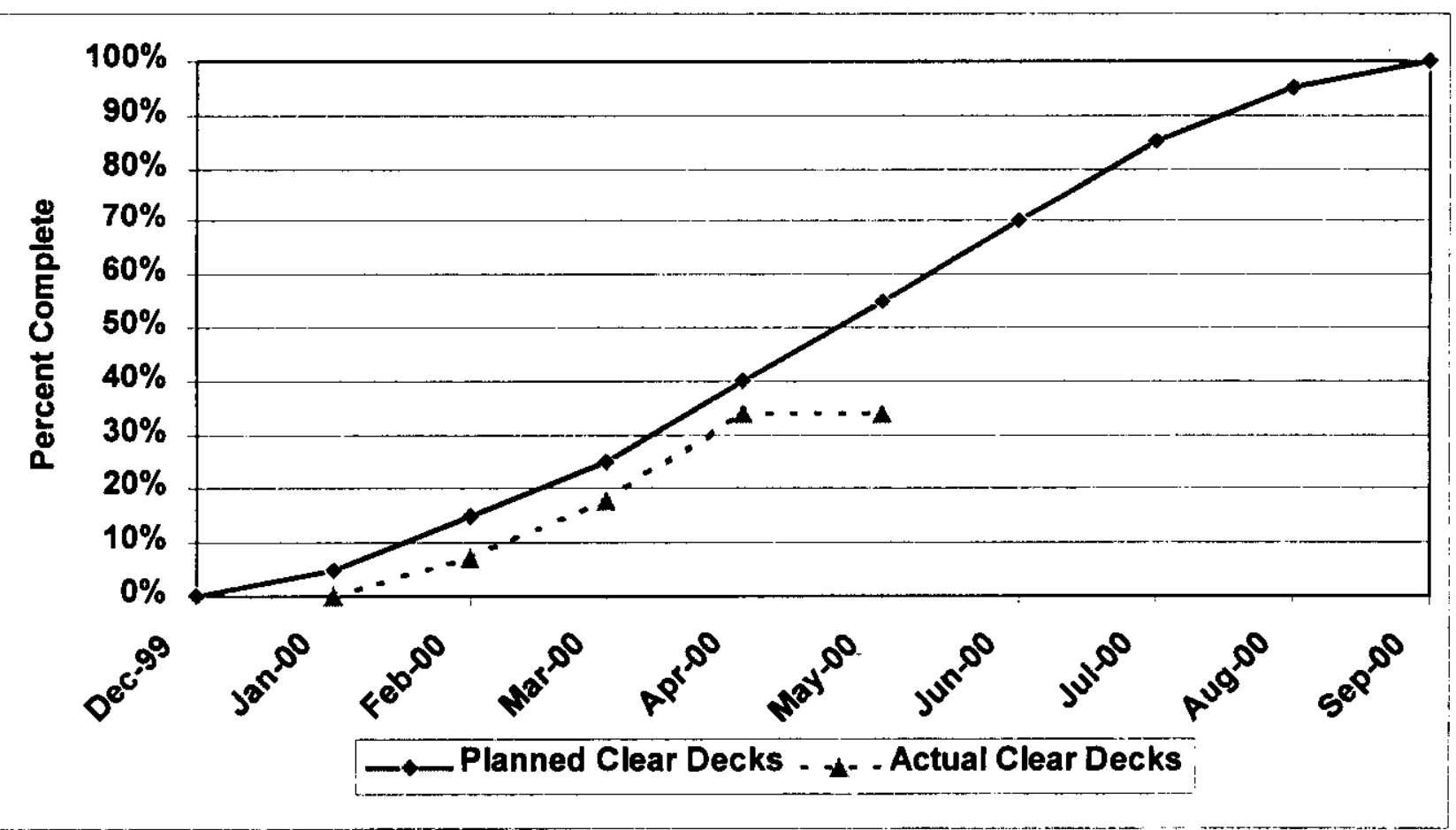

Action Plans: On track for Project Execution Plan (PEP) completion in June 2000 and completion of the Conceptual Design Document (CDD) in September 2000. 


\section{T Plant Tower Removal \\ (RC-4-1-2)}

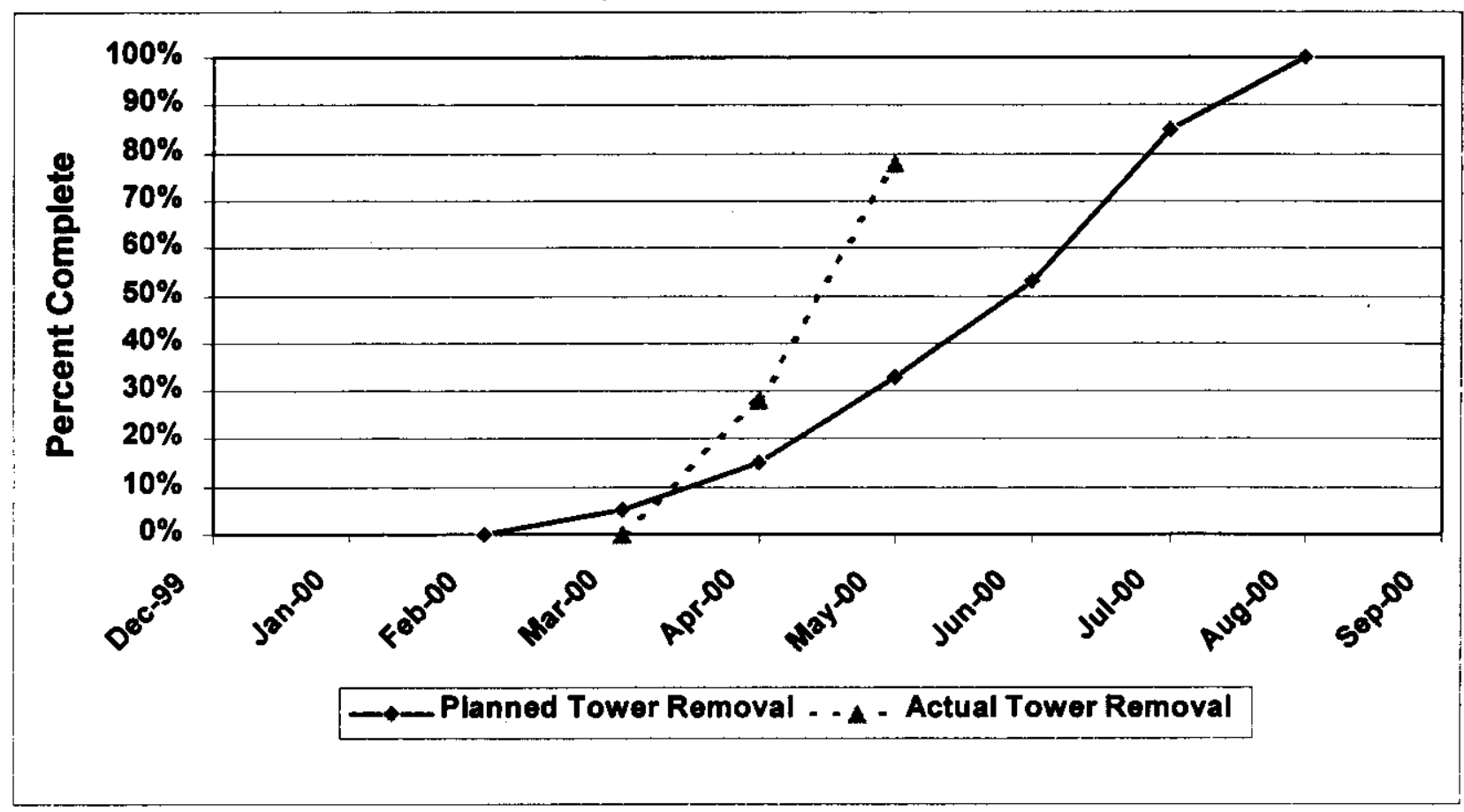

Action Plans: On track for removal of two PUREX Towers from the T Plant canyon by September 2000. PUREX Tower T-C3-1 was successfully shipped to LLBG, unloaded and buried on June 1, 2000.

\section{KEY INTEGRATION ACTIVITIES}

- $\quad$ Preparing T Plant to receive Spent Nuclear Fuel K Basin sludge.

- Issuance of Records of Decision for LLW and MLLW is expected to affect Hanford's role in disposing of waste from other sites. Working with DOE-RL, DOE-HQ, WDOE and other Sites to develop and define Hanford's role as one of the identified LLW/MLLW disposal sites for the Complex.

- Support continued UP-1 Groundwater treatment.

- Support River Corridor Project in cleanup and removal of waste from 324 and 327 buildings.

- $\quad$ Support DOE-RL declaration of Readiness-to-Proceed in support of the ORP Privatization contract.

- $\quad$ Continue working with PNNL, EM 50 and Mixed Waste Focus Area (MWFA) to obtain funding in support of mixed waste processing (M-91 Facility Project).

- Continue to work with DOE- RL, -Oakland, and -Ohio to support resolution of TRU small quantity site disposition issues. 
PHMC Environmental Management Performance Report - July 2000

Section B:2 - Analytical Services (222-S, HASP, WSCF)

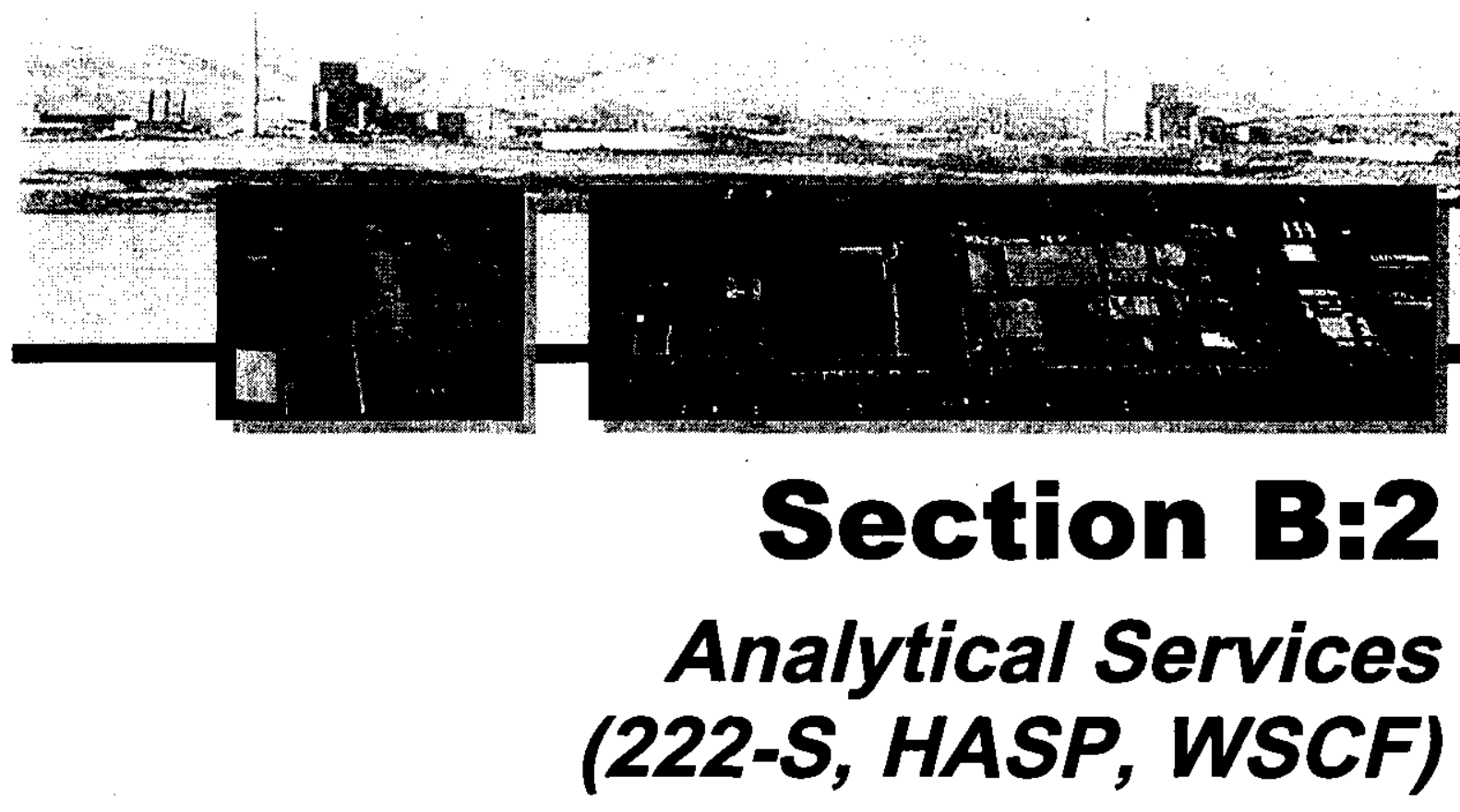

PROJECT MANAGERS

S.H. Wisness, RL (509) 373-9337

D.L. Renberger, $\mathrm{FH}$ (509) 372-0877 


\section{SUMMARY}

Analytical Services [222-S, Hanford Analytical Services Program (HASP), Waste Sampling and Characterization Facility (WSCF)] consists of Analytical Services, PBS WM06, WBS 1.2.4.

NOTE: Unless otherwise noted, the Safety, Conduct of Operations, Milestone Achievement, and Cost/Schedule data contained herein is as of May 31, 2000. Other information is updated as noted.

Fiscal-year-to-date-milestone performance (EA, DOE-HQ and RL) shows no milestones are due this reporting period.

\section{ACCOMPLISHMENTS}

- A total of 8.0 Analytical Equivalent Unit (AEUs) processed at the 222-S Laboratory through May 2000 (FYTD) versus the planned 8.1 AEUs in support of the RPP (TWRS) tank characterization program. Production through June 16 is 8.8 AEUs. On track to meet the 11 AEU commitment. Completed analysis and reporting for characterization of high-level waste in AZ-102, and compatibility analysis on tanks U-106 and SY-102.

- $\quad$ Supported completion of the 242A Evaporator campaign that was completed on May 2, seven days ahead of schedule. Performed 11,600 analyses (FYTD) through May 2000 at Waste Sampling and Characterization Facility (WSCF) for a wide variety of customers as planned. Production through June 12, 2000 is 12,100 analyses. Completed headspace gas sampling and analysis on 85 drums for Waste Isolation Pilot Plant (WIPP).

- $\quad$ Received results on the DOE Mixed Analyte Performance Evaluation Program (MAPEP). All programs (trace metals, semi-Volatile Organic Analysis (VOA), and radiochemistry) had acceptable results. No formal corrective actions are required by WSCF.

- Environmental Management Consolidated Audit Program (EMCAP) and Integrated Contractor Purchasing Team (ICPT) Audits of RECRA Laboratories in Lionville, Pennsylvania were conducted on May 16-18 and May 23-25, 2000. The purpose of these audits is to determine the RECRA Laboratories' compliance to Hanford Analytical Services Quality Requirements Document (HASQARD) and other applicable requirements for performing analytical services on Hanford samples. Findings are being addressed by RECRA and the laboratory continues to be utilized. 


\section{SAFETY}

In May, there were no Occupational Safety and Health Act (OSHA) recordable cases, one lost/restricted days and four first aid cases. The project continues to focus on safety and personal and team accountability; however, there is a significant increase in the Lost/Restricted Workday Case Rate for Nov 99 - Jan 00, and a significant increase in First Aid Cases over the past eight months. OSHA recordable is stable at a rate higher than the 1.0 corporate goal. A safety council sponsored, employee-lead task team is working to develop near-term and long-term improvements in the ergonomics of handling small casks (called T-handled carriers). Ergonomics training was completed by HEHF at the 222-S Laboratory in May 2000 and additional ergonomics sessions are planned to be made available to all Analytical Services staff. Ergonomic self-assessments are planned for all Analytical Services staff for June and July 2000. Ergonomics have been a source of injuries that need to be prevented. 


\section{Lost Away Workday Case Rate \\ Cases per 200,000 hours}

10

2

0

12 OSHA Recordable Case Rate

Cases per 200,000 hours

FY 2000 to date $=1.0$

$1,600,000$ hours without

a Lost Away Work Day Case

(Oct 96 - Apr 99)

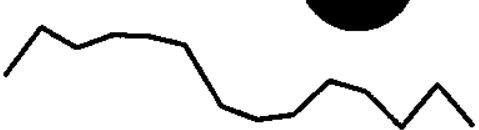

Average $=1.4$

(Apr 99 - Nov 99)

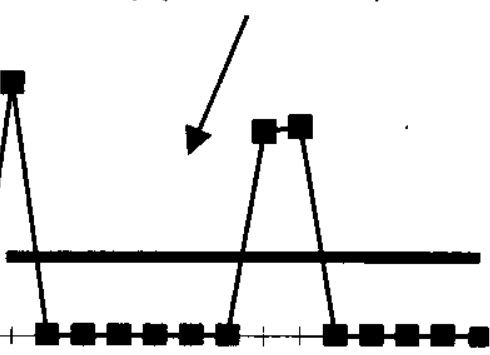

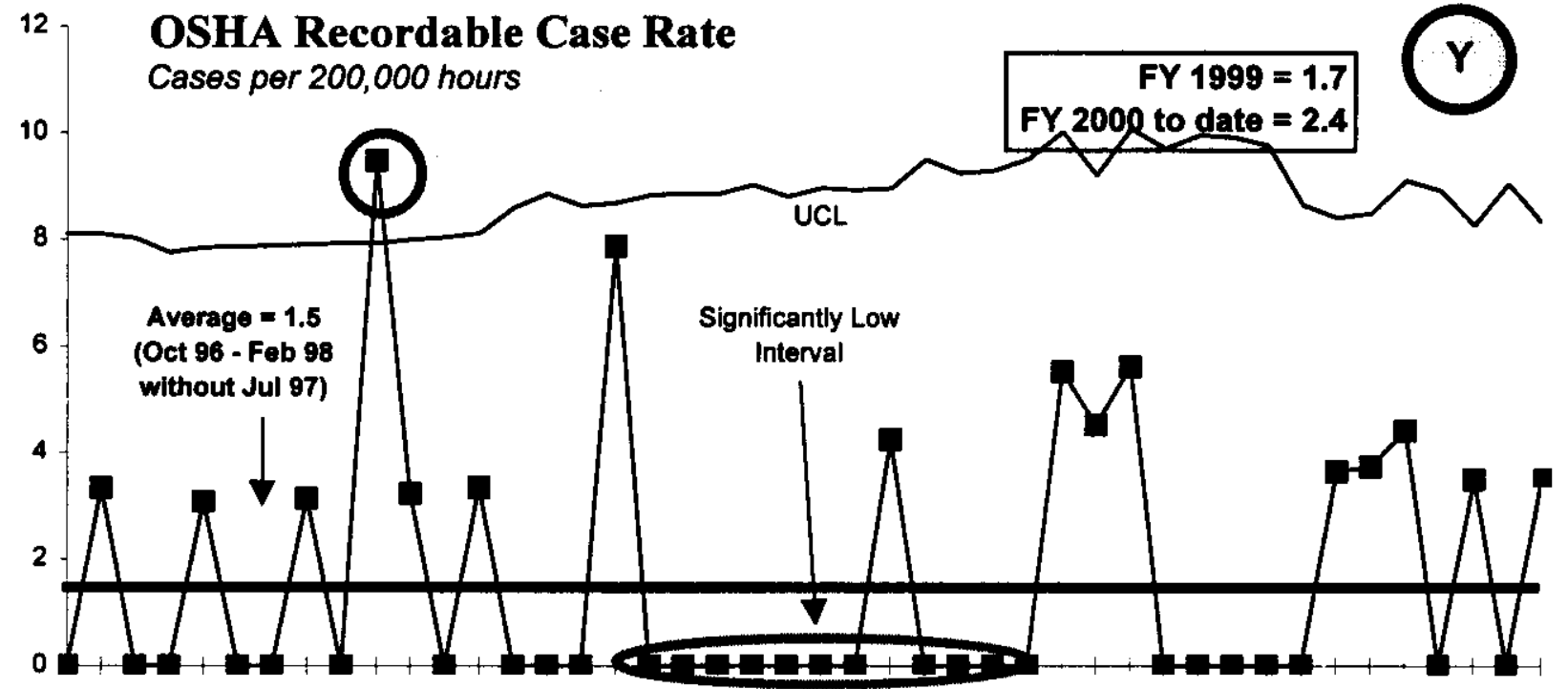

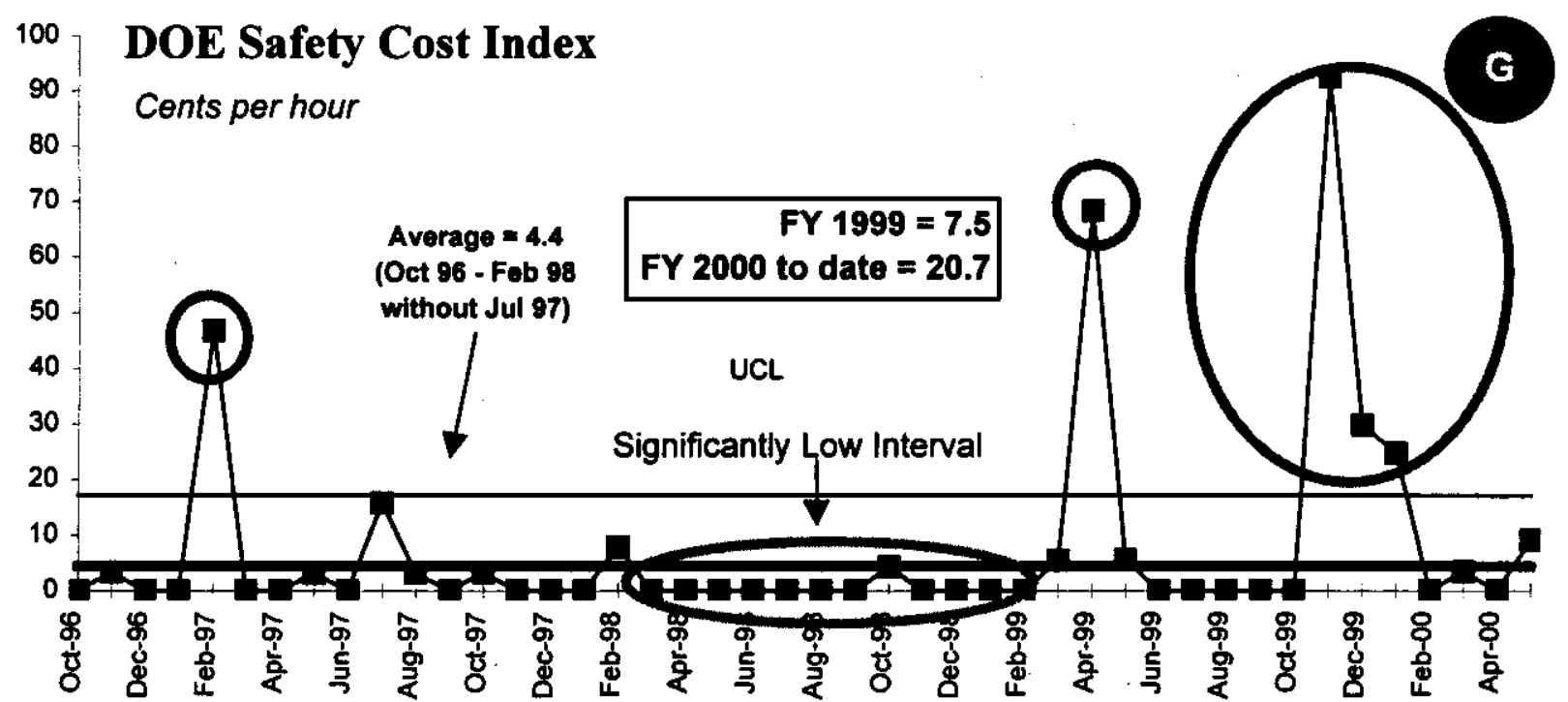

DOE/RL-99-83, Rev. 6 


\section{CONDUCT OF OPERATIONS / ISMS STATUS CONDUCT OF OPERATIONS \\ EVENTS PER 200,000 HOURS}

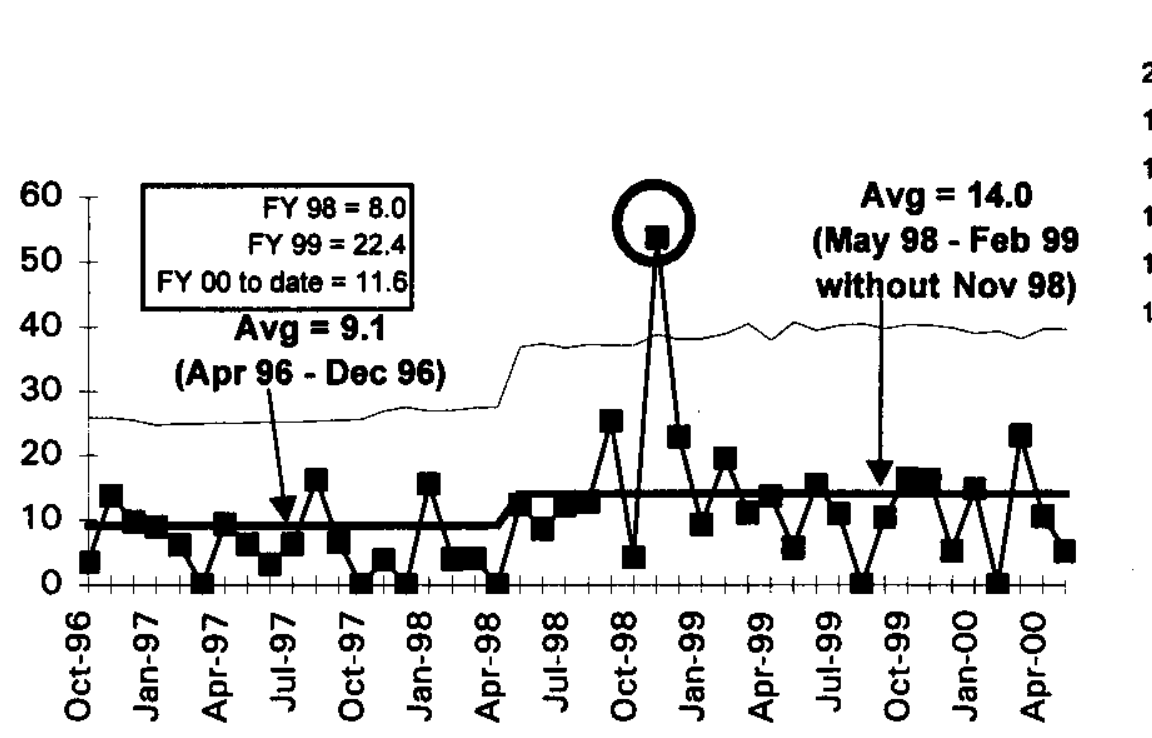

No. of Reports

Past 12 Months

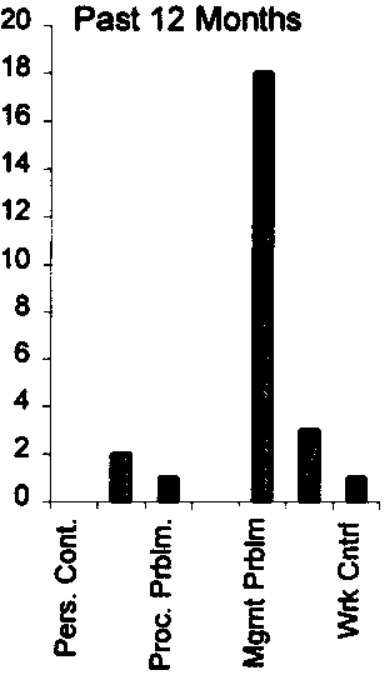

\section{ISMS STATUS}

Analytical Services ISMS status is included in the Waste Management

Project Section of this report. Overall, on track for the June 2000 Phase II verification. Prepare Projects for, and support DOE Phase II efforts.

\section{BREAKTHROUGHS}

Nothing to report.

\section{OPPORTUNITIES FOR IMPROVEMENT}

British Nuclear Fuel Limited, Inc. (BNFL) and Bechtel National, Inc. have begun (May 2000) providing laboratory analytical requirements and turnaround time needs to determine whether support from 222-S/WSCF would enable a significant downsizing of the process support laboratory planned for the vitrification plant. A white paper was funded by $\mathrm{CH} 2 \mathrm{M}$ Hill Group (CHG) to estimate cost reduction opportunities through the use of 222-S and WSCF resources.

\section{UPCOMING ACTIVITIES}

WIPP Certification and Waste Shipments - Continue to support the production goal of headspace analysis of 253 drums (equivalent) for shipment to WIPP. 
ORP Readiness to Proceed - It has been determined that Analytical Services is prepared to support the readiness to proceed decision for the BNFL/Bechtel National, Inc. contract. Key follow-up actions are:

- Formal specification of requirements from Occurrence Reporting Program (ORP) to RL and then to $\mathrm{FH}$

- Stable funding of needed equipment and facility repair in Multi-Year Work Plans (RL and ORP)

- $\quad$ Funding replacement of obsolete laboratory support systems (Information Management)

- Funding of staff to maintain core competency.

\section{Cost Performance (\$M):}

\begin{tabular}{|l|c|c|c|}
\hline & BCWP & ACWP & VARIANCE \\
\hline Analytical Services & $\$ 18.0$ & $\$ 19.1$ & $-\$ 1.1$ \\
\hline
\end{tabular}

The $\$ 1.1$ million (6 percent) unfavorable cost variance is due to increased cost for 222-S Laboratory polychlorinated biphenyl (PCB) recovery and increased resources required to support compliance issues.

\section{SChedule Performance (\$M):}

\begin{tabular}{|l|c|c|c|}
\hline & BCWP & BCWS & VARIANCE \\
\hline Analytical Services & $\$ 18.0$ & $\$ 18.3$ & $-\$ 0.3$ \\
\hline
\end{tabular}

The $\$ 0.3$ million ( 2 percent) unfavorable schedule variance is within the established threshold.

\section{FY 2000 Cost/Schedule Performance - All Fund Types Cumulative to Date Status - $(\$ 000)$ FYTD}

\begin{tabular}{lllllllllllll}
\multicolumn{2}{c}{ By PBS } & BCWS & BCWP & ACWP & SV & $\%$ & CV & $\%$ & PEM & FYSF & EAC \\
WBS 1.2.4 & Analytical & & & & & & & & & & & \\
PBSWM06 & Services & $\$ 18,330$ & $\$ 18,009$ & $\$ 19,134$ & $\$(321)$ & $-2 \%$ & $\$(1,125)$ & $-6 \%$ & $\$ 27,101$ & $\$ 27,594$ & $\$ 27,992$ \\
\cline { 2 - 12 } & Total & $\$ 18,330$ & $\$ 18,009$ & $\$ 19,134$ & $\$(321)$ & $-2 \%$ & $\$(1,125)$ & $-6 \%$ & $\$ 27,101$ & $\$ 27,594$ & $\$ 27,992$
\end{tabular}

*Note: RL-Directed costs (steam and laundry) are included in the PEM BCWS. The current spending forecast indicates an overrun of $\$ 0.9 \mathrm{M}$ due to the unforeseen significant extra costs for Polychlorinated biphenyl (PCB) management. A BCR has been approved to address incremental scope for PCB recovery that will significantly reduce the unfavorable cost variance. 


\section{COST/SCHEDUle Performance INDiCes (MONTHLY AND FYTD)}

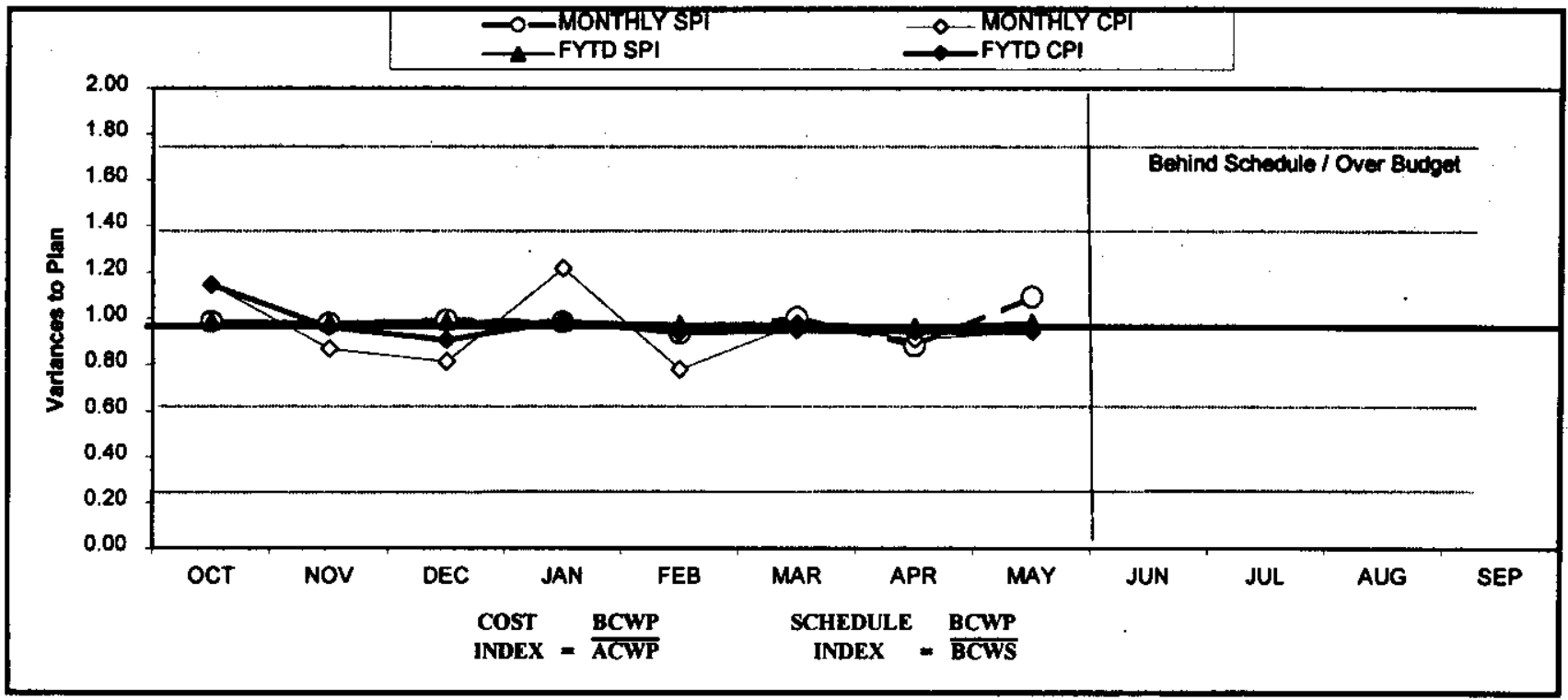

\begin{tabular}{|c|c|c|c|c|c|c|c|c|c|c|c|c|}
\hline FY 2000 & OCT & NOV & DEC & JAN & FEB & MAK & APR & MAY & JUN & JUL & AUG & SEP \\
\hline MONTHLYSPI & 0.99 & 0.98 & 0.99 & 0.98 & 0.94 & 1.00 & 0.88 & 7.09 & & & & \\
\hline MONIFLYCPT & 1.14 & 0.87 & 0.81 & T.22 & 0.78 & 0.98 & 0.91 & 0.94 & & & & \\
\hline FYTDSPI & 0.99 & 0.98 & 0.99 & 0.98 & 0.97 & 0.98 & 0.97 & 0.98 & & & & \\
\hline FYTDCPT & 7.14 & 0.96 & 0.91 & 0.99 & 0.94 & 0.95 & 0.94 & 0.94 & & & & \\
\hline MONIALY BCWS & 51,388 & 52,340 & 31,973 & $52,8 \%$ & 52,283 & $\$ 2,613$ & 32,279 & 52,358 & 31,927 & 31,893 & $\$ 2,307$ & 32,444 \\
\hline MONIFILYBCWP & 51,366 & $\mathbf{5 2 , 2 8 8}$ & \$1,960 & 32,848 & 52,135 & $\$ 2,624$ & 52,010 & 52,578 & & & & \\
\hline MONTHLYACWP & 51,369 & $\$ 2,640$ & 32,414 & $\mathbf{5 2 , 3 4 2}$ & 32,741 & $\$ 2,686$ & $\$ 2,208$ & 52,733 & & & & \\
\hline FYTDBCWS & \$1,388 & 33,928 & 35,901 & $\$ 8,797$ & $\$ 11,080$ & 313,693 & 315,973 & 318,330 & 320,257 & 322,150 & 324,657 & 327,101 \\
\hline FYTDBCWP & $\$ 1,366$ & $\mathbf{3 3 , 8 5 4}$ & 33,814 & 38,662 & $\$ 10,797$ & $\$ 13,421$ & S15,431 & 518,009 & & & & \\
\hline FYTDACWP & 31,369 & 34,009 & 56,423 & 38,765 & 311,306 & 514,193 & 316,401 & डा9,134 & & & & \\
\hline
\end{tabular}

\section{COST VARIANCE ANALYSIS: (- \$1.1M)}

\section{$\underline{\text { WBS/PBS }} \quad \underline{T i t l e}$}

\subsection{4/WM06 Analytical Services}

Description/Cause: The unfavorable cost variance of $\$ 1.1$ million (6.3 percent) is due to increased costs for 222-S Tank 104 poly-chlorinated biphenyl recovery activities; increased resources in support of compliance issues, ISM implementation, corrective action management, and chemical technologist training development.

Impact: Current yearend spending projections indicate a $\$ 0.9 \mathrm{M}$ overrun.

Corrective Action: Corrective actions have been identified and implemented to control spending, including the processing of a change request to address the incremental PCB recovery scope. 


\section{SCHEDUle VARIANCE ANAlysis: ( $\quad \$ 0.3 M)$}

\section{WBS/PBS}

1.2.4/WM06

Description /Cause: The unfavorable schedule variance of $\$ 0.3 \mathrm{M}$ (2 percent) is within established threshold.

Impact: None.

Corrective Action: None required.

\section{ISSUES}

\section{Technical Issues}

None.

\section{DOE/Regulator/External Issues}

PCB Management - ORP is establishing a new PCB management approach. Impacts to 222-S and WSCF could be significant and very costly, depending on the final approach taken by ORP. DOE-RL plans to seek funding from ORP to assess impacts and implementation costs of ORP changes in regulation approach. Provided input and supported a FH team to respond to the ORP negotiations being held with EPA on the PCB status of the tank farms.

222-S RCRA Part B Application - DOE-RL received letter notification from Ecology granting a delay in submittal of the 222-S Laboratory Part B RCRA Application until August 31, 2000. This delay is shorter than requested, AS will present the new technical challenges (i.e., TSCA in the DST system). Analytical Services requested a three-month delay to allow for continued good progress for resolving issues and should result in permit conditions that can be implemented.

\section{Baseline Change Requests Currently in Process $(\$ 000)$}

\begin{tabular}{|c|c|c|c|c|c|c|c|c|c|}
\hline $\begin{array}{l}\text { PROAECT } \\
\text { CHANGEE } \\
\text { NUMBER } \\
\end{array}$ & $\begin{array}{l}\text { DATE } \\
\text { ORIGIN. }\end{array}$ & BCR TIILE & $\begin{array}{c}\text { FY00 } \\
\text { COST } \\
\text { IMPACT } \\
\text { SA00 } \\
\end{array}$ & $\mathrm{SCH}$ & TECH & $\underset{\text { CCB }}{\mid \text { DATE TO }}$ & $\begin{array}{c}\text { CCB } \\
\text { APR'VD } \\
\end{array}$ & RL APR'VD & $\begin{array}{l}\text { CURRENT } \\
\text { STATUS } \\
\end{array}$ \\
\hline WM-2000-002 & $1 / 3 / 00$ & $\begin{array}{l}\text { Waste Management FY } 2000 \text { Mandated } \\
\text { Funds Reduction }\end{array}$ & -5879 & & & $02 / 17 / 00$ & & & $\begin{array}{l}\text { Approved by RL } \\
\text { 5/15/2000 }\end{array}$ \\
\hline \multicolumn{10}{|c|}{ ADVANCE WORK AUTHORIZATIONS } \\
\hline & & Nothing to report at this time. & & & & & & & \\
\hline
\end{tabular}




\section{ANALYTICAL SERVICES - WBS 1.2.4 MILESTONE ACHIEVEMENT}

\begin{tabular}{|c|c|c|c|c|c|c|c|c|}
\hline \multirow[b]{2}{*}{ MILESTONE TYPE } & \multicolumn{4}{|c|}{ FISCAL YEAR-TO-DATE } & \multicolumn{3}{|c|}{ REMAINING SCHEDULED } & \multirow[b]{2}{*}{$\begin{array}{l}\text { TOTAL } \\
\text { FY } 2000\end{array}$} \\
\hline & $\begin{array}{c}\text { Completed } \\
\text { Early }\end{array}$ & $\begin{array}{c}\text { Completed } \\
\text { On } \\
\text { Schedule }\end{array}$ & $\begin{array}{l}\text { Completed } \\
\text { Late }\end{array}$ & Overdue & $\begin{array}{c}\text { Forecast } \\
\text { Early }\end{array}$ & $\begin{array}{l}\text { Forecast } \\
\text { On } \\
\text { Schedule }\end{array}$ & $\begin{array}{l}\text { Forecast } \\
\text { Late }\end{array}$ & \\
\hline Enforceable Agreement & 0 & 0 & 0 & $\overline{0}$ & $\mathbf{0}$ & 0 & $\overline{0}$ & $\overline{0}$ \\
\hline DOE-HQ & 0 & 0 & 0 & 0 & 0 & 0 & 0 & 0 \\
\hline $\mathrm{FO}$ & 0 & 0 & 0 & 0 & 0 & 0 & 0 & $\mathbf{0}$ \\
\hline $\mathbf{R L}$ & 0 & 0 & 0 & $\mathbf{0}$ & 0 & 1 & 0 & 1 \\
\hline Total Project & 0 & 0 & 0 & 0 & 0 & 1 & 0 & \\
\hline
\end{tabular}

\section{MILESTONE EXCEPTION REPORT}

Number/WBS Level Milestone Title Date

\section{OVERDUe - 0}

FORECAST LATE - 0 


\section{Section B 2,100}

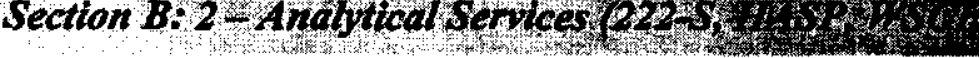

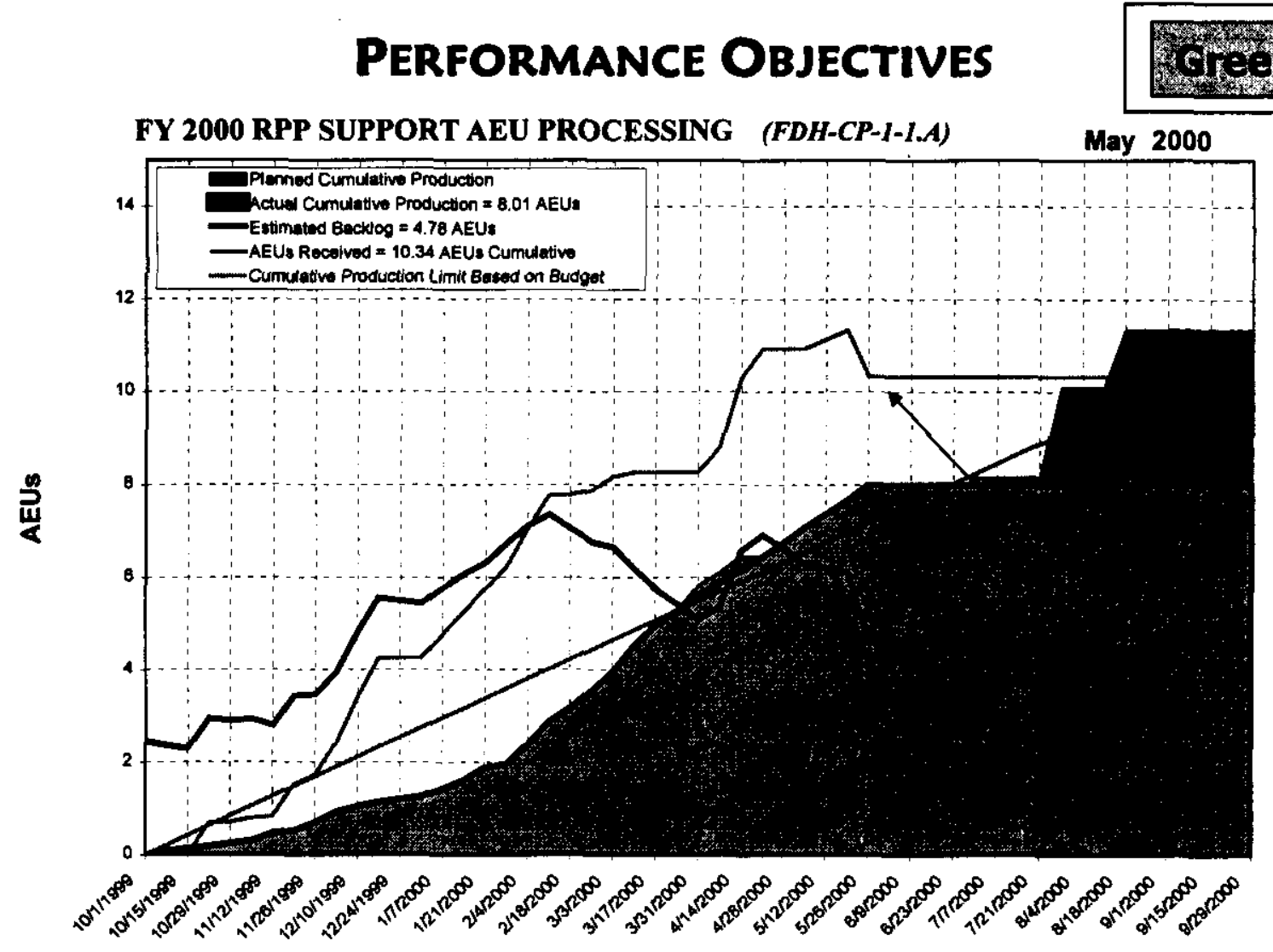

Continue working with RPP on 222-S laboratory production integration. Will meet the September 2000 commitment of eleven AEUs. Production through May 2000 is 8.0 AEUs, versus a planned 8.1 AEUs. Production through June 16, 2000 is 8.8 AEUs.

\section{KEY INTEGRATION ACTIVITIES}

- Continue to support BNFL/Bechtel efforts to establish required analytical support for glassification operations.

- In the longer term, BNFL/Bechtel National, Inc. could utilize unused space at WSCF for cold run test support and process laboratory analytical equipment testing.

- The 222-S laboratory, with some refurbishment, might become a low cost option to a new large-scale laboratory associated with the glassification facility.

- A white paper is being prepared for RPP to address the potential support that 222-S and WSCF could provide to the glassification facility. 


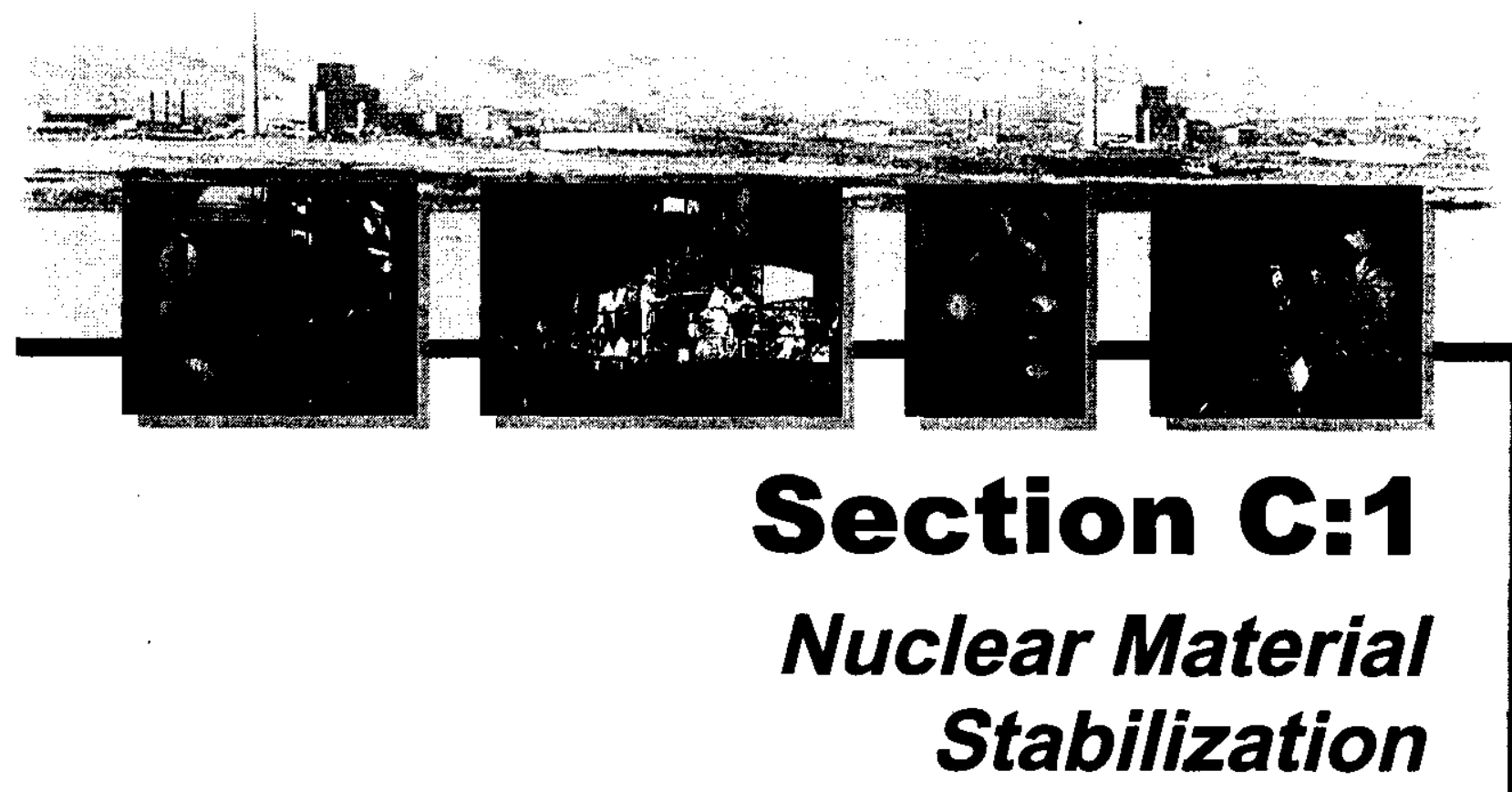

PROJECT MANAGERS

P.M. Knollmeyer, RL (509) 376-7435

G.W. Jackson, FH (509) 373-6622 


\section{SUMMARY}

The Nuclear Material Stabilization mission consists of the Plutonium Finishing Plant (PFP), WBS 1.4.5, PBS TP05.

NOTE: Unless otherwise noted, the Safety, Conduct of Operations, Milestone Achievement, and Cost/Schedule data contained herein is as of May 31, 2000. All other information is as of June 16,2000 unless otherwise stated.

As of June 16, 2000 a total of 290 cans of Plutonium oxides and sludges have been stabilized through thermal stabilization ( 35 additional items since last report). A total of 13 liters of Plutonium nitrate solution have been stabilized in the prototype vertical denitration calciner [no change since December 1999 due to focus on $\mathrm{Mg}(\mathrm{OH})_{2}$ Precipitation Process installation activities].

As of June 16, 2000, there have been 196 days without a lost workday injury, attributed to following Integrated Safety Management System (ISMS) principles.

Fiscal-year-to-date milestone performance (EA, DOE-HQ, and RL) shows that three of eight milestones (38percent) were completed on or ahead of schedule, one completed late (12 percent), and four (50 percent) are overdue. Three milestones were completed during this report period. Milestone M-15-37B, "Deliver 2 Validated Data Packages to EPA" was completed on schedule. TRP-00-415, "Complete Project W-460 Facility Design", and TRP-00-510, "Complete Annual Revision to the Integrated Project Management Plan (IPMP)" were also completed. An RL approved change in the preferred method for stabilization of residues/solution has resulted in a request to delete three milestones. These include; TRP-00-500, "Install Two LANL Pyrolysis Units for Stabilization of Polycubes," TRP-99-419, ""Complete Installation of Production Scale Vertical Calciner", and TRP-99-500, "Complete Installation and Testing of Production Vertical Calciner." TRP-00-504, "Restart Cementation," is overdue because of re-sequencing of the stabilization processing. Cementation of Sand, Slag, and Crucible (SS\&C) material processing will be delayed until FY 2001. Further details can be found in the milestone exception report following the cost and schedule variance analysis.

\section{ACCOMPLISHMENTS}

\section{Maintain Safe and Compliant PFP}

- As of June 16, 2000, there have been 196 days without a lost workday injury.

- Completed Tri-Party Agreement milestone, Deliver 2 Validated Data Packages To EPA (M-15-37B) by May 31, 2000 on schedule.

- The Facility Evaluation Board (FEB) conducted an annual assessment of the PFP and concluded that overall plant performance has steadily improved during the past 2 years.

- An assessment is currently underway to verify implementation of the Integrated Safety Management System (ISMS). Surveillance Operations Support has maintained a zero delinquency rate for Action Requests and Assignments for Corrective Action Management for the fifteenth consecutive week. 
- Items identified by the Facility Evaluation Board are in review by the Deficiency Evaluation Group. Corrective actions are being implemented as reviews are completed.

\section{Maintain Safe \& Secure SNM}

- Completed monthly AD HOC International Atomic Energy Agency (IAEA) inspection and relocation of the agency's multiplexer (MUX) cabinet to room 635 .

- Transferred material from the IAEA vault to room 642 in support of the IAEA inspectors setup and calibration of their new non-destructive assay (NDA) equipment.

- Supported transfers of material to/from Thermal Stabilization and performed NDA of newly stabilized material without impact to performance schedule.

\section{Oxides/Metals/Polycubes Stabilization}

- All five furnaces are now available for operation.

- Completed stabilization of 290 Pu oxide items as of June 16, 2000.

- Testing to demonstrate achieving the DOE-STD-3013 criteria for thermal treatment of oxides (950 degrees $\mathrm{C}$ for two hours) was completed for surrogates of oxides, $\mathrm{Mg}(\mathrm{OH})_{2}$ and residues. This testing demonstrated that the criteria is being exceeded.

- Initiated opening and brushing of eight "at risk" Pu metal items in 2736-ZB, with two items completed as of June 12.

\section{Solution Stabilization}

- The projected completion date for $\mathrm{Mg}(\mathrm{OH})_{2}$ glovebox tie-in to 234-5Z building exhaust ventilation has improved from July 30 to July 19, 2000.

- Continue with double construction shifts (28-hour shifts, 6 days/week) to regain schedule from technical delays.

- Plan of Action for the Operations Readiness Review (ORR) being finalized prior to submittal to RL for approval.

- Equipment for the testing of the magnesium hydroxide process received from the Pacific Northwest National Laboratory (PNNL) was transferred to Glovebox 179-4 on June 16, 2000.

- A draft report on the thermal stabilization furnace temperature tests is being prepared.

\section{Polycube Stabilization}

- Laboratory testing of Polycubes was completed and a report was issued to DOE-RL. Testing shows that an 800 gram charge can be safely stabilized via oxidation in a muffle furnace.

\section{Project W-460}

- Completed Milestone TRP-00-415, Project W-460 Facility Design with minimal schedule delays.

- The Washington State Department of Health has approved the Notice of Construction (NOC) for the 234-5Z Bagless Transfer System (BTS).

- Received BTS unit from SRS for installation into 234-5Z.

- An existing FMEF glove box has been approved for use at PFP with the 234-5Z BTS.

- The outer can welder mock-up began operation on June 15, 2000. This activity will provide pre-startup training and procedure verification.

- Order for 2nd BTS unit has been placed and the Memorandum of Understanding (MOU) has been approved. 


\section{SAFETY}

Safety performance continued to be excellent in April with no OSHA Recordable or Lost Workday Case injuries.

The DOE Safety Cost Index has both a new average and control limits reflecting the significant decrease noted earlier in the year. FY 2000 OSHA case rate and DOE Safety Cost Index are very favorable. OSHA recordable case rate has significantly improved in comparison to the adverse trend of Spring 1999. As of June 16, 2000 there have been 196 days without a lost workday injury. 

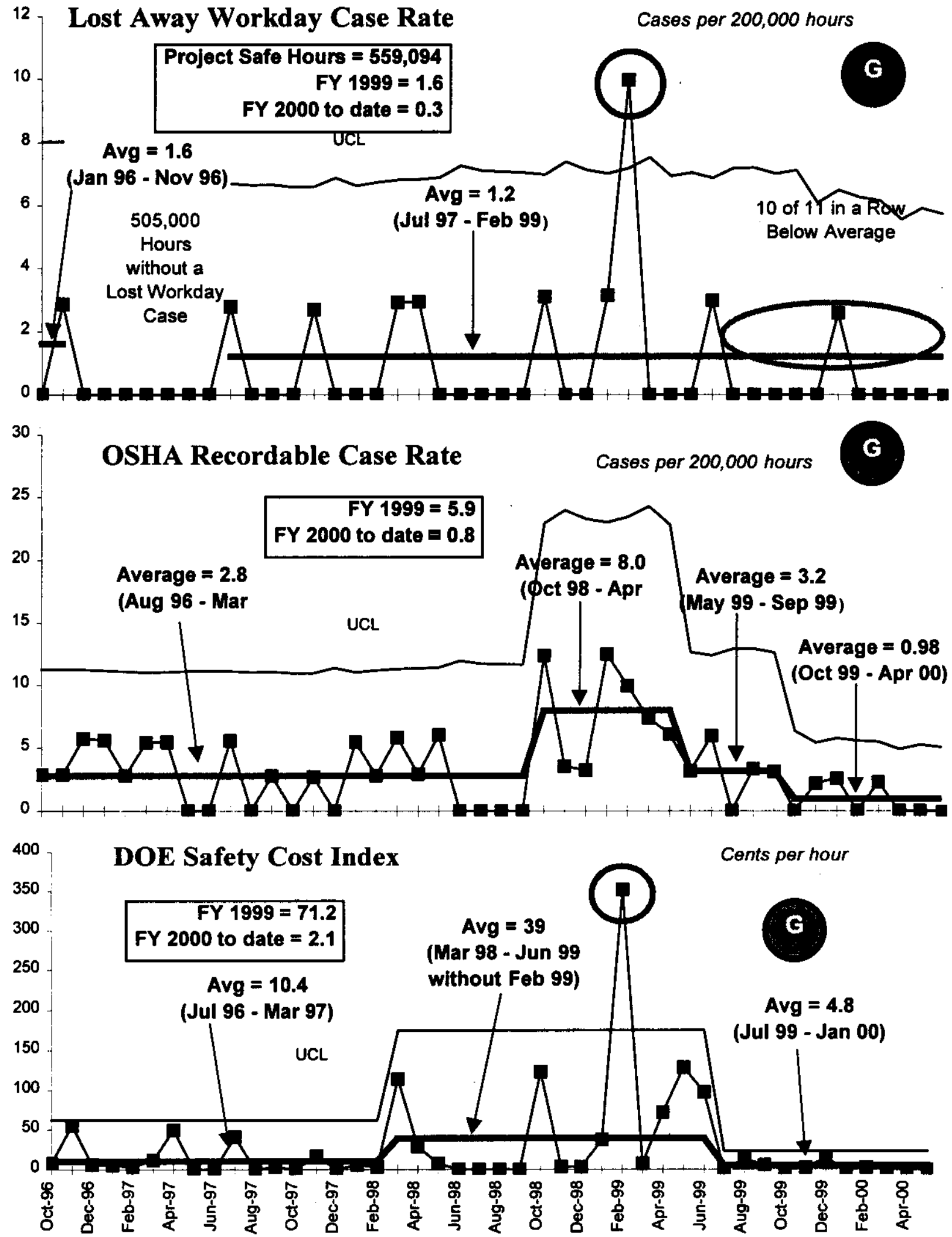


\section{CONDUCT OF OPERATIONS / ISMS STATUS \\ CONDUCT OF OPERATIONS}

Events per 200,000 Hours
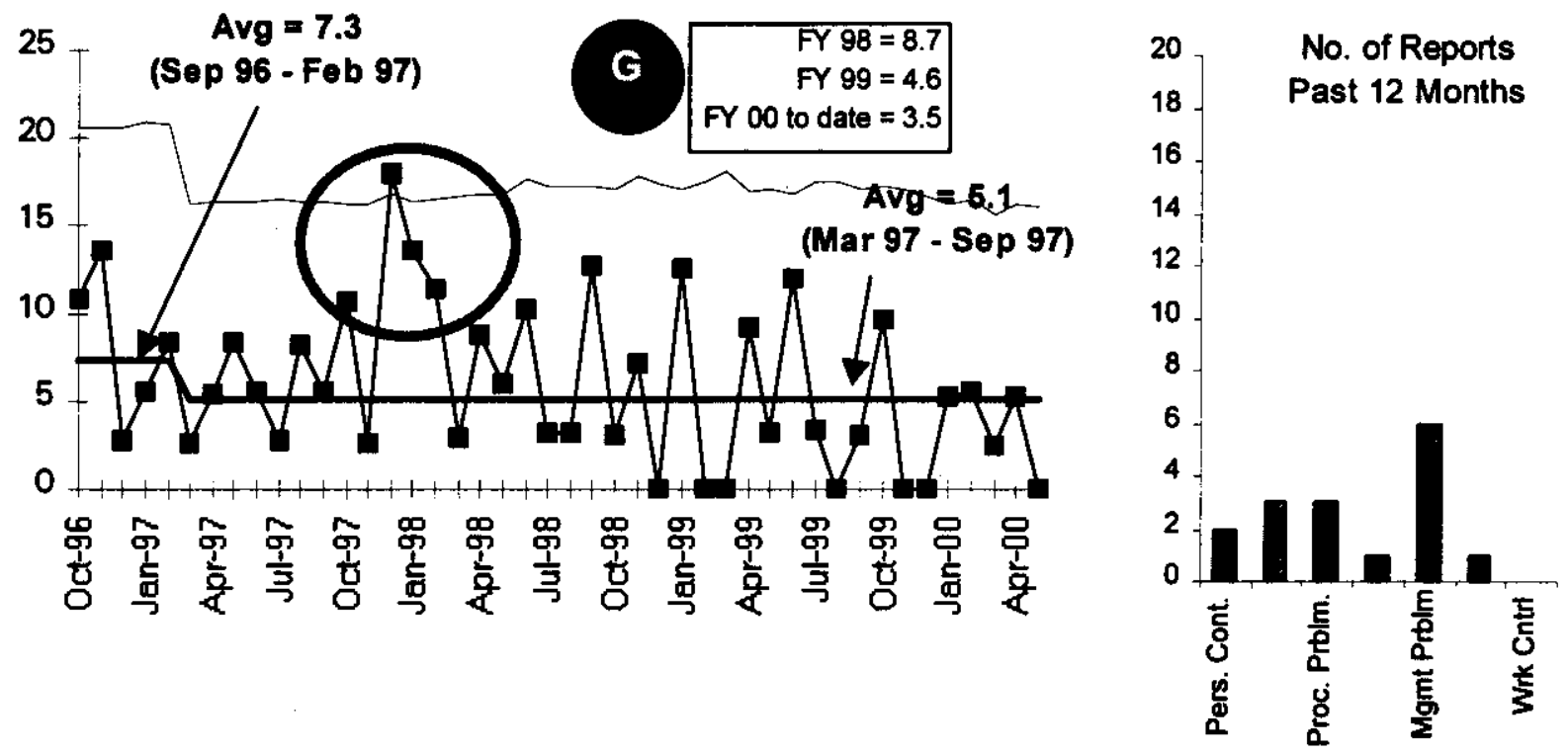

\section{ISMS STATUS}

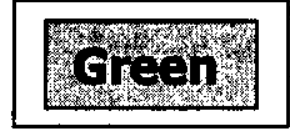

- All action items resulting from the Nuclear Material Stabilization

Project Phase 1 verification assessment of the Integrated Safety Management System implementation has been completed.

- Phase II verification has been initiated.

\section{BREAKTHROUGHS / OPPORTUNITIES FOR IMPROVEMENT}

\section{Breakthroughs}

- Implementation of a WIPP "validated" plutonium measuring nondestructive assay (NDA) system in FY 2000 continues. The equipment necessary to upgrade the Segmented Gamma Scanner will be delivered by the end of June.

- Identified method to repair the existing floor in room 192D instead of replacement, which reduces schedule impact, radiological concern and waste disposal costs.

- Recommendations for modification of Personnel Security Assurance Program (PSAP) twoman rule requirements, which would provide a potential reduction of resources for facility surveillance and maintenance activities, was submitted to $\mathrm{RL}$ for review and approval. Protection Technology Hanford began training managers responsible for PSAP June 16, 2000 . 


\section{Opportunities for Improvement}

- The new Criticality Safety Evaluation Report (CSER) allowing an additional boat in HC18BS was approved at PFP. The Criticality Prevention Specification (CPS) has been drafted and is in review. Installation of a 234-5Z BTS unit provides the opportunity to accelerate packaging to DOE Standard 3013 criteria and significantly reduces overall radiation exposure to staff.

- Implement ALARA dose reduction measures:

- Robotic (remote surveillance)

- Room 638 cage shielding

- Full scale mock-up vault cubicles

- Contracted with Westinghouse Savannah River Company to provide Outer Can Welder. This will allow review and approval by 3013 Design Authority and ensure final approvals will be expedited.

\section{UPCOMING ACTIVITIES}

- $\quad$ Begin Pu solution stabilization via $\mathrm{Mg}(\mathrm{OH})_{2}$ in the fourth quarter of FY 2000.

- Complete glovebox installation in July 2000.

- Complete ORR and training activities for stabilization activities in room 230-C in September 2000.

- $\quad$ Startup Residues operations in fourth quarter of FY 2000.

- Complete installation and startup of the 234-5Z Bagless Transfer System (BTS) in fourth quarter of FY 2000.

- Begin metal stabilization processing in November 2000.

- Initiate polycube stabilization in first quarter of FY 2001.

\section{Cost Performance $(-\$ 10.2 \mathrm{M})$ :}

\begin{tabular}{|l|c|c|c|}
\hline & BCWP & ACWP & VARIANCE \\
\hline Nuclear Material Stabilization & $\$ 70.1$ & $\$ 80.3$ & $-\$ 10.2$ \\
\hline
\end{tabular}

The \$10.2 million (14 percent) unfavorable cost variance is mostly driven by overruns in Solution Stabilization and in NMS Project Management (PBS RL-TP-12). Increased resources for the $\mathrm{Mg}(\mathrm{OH})_{2}$ glovebox design, procurement and installation have been necessary to maintain the aggressive schedule demands. The cost overruns are somewhat offset by underruns in other areas due to a shortage of staff. 


\section{SChedule Performance (-\$15.2M):}

\begin{tabular}{|l|c|c|c|}
\hline & BCWP & BCWS & VARIANCE \\
\hline Nuclear Material Stabilization & $\$ 70.1$ & $\$ 85.3$ & $\mathbf{- \$ 1 5 . 2}$ \\
\hline
\end{tabular}

The $\$ 15.2$ million (18 percent) unfavorable schedule variance is due to the behind status on Project W-460, the Plutonium Stabilization and Packaging System, capital activities, such as the elimination of trailers and vault modification design. Facility construction modifications have not started as scheduled due to deviations in the definitive design, required changes to the National Environmental Policy Act (NEPA) Supplemental Analysis and approval of the Notice of Construction by the Washington State Department of Health. Residues and solution stabilization activities are also the behind schedule. Solution stabilization construction activities are two months behind schedule, with startup now planned for September 2000. Restart activities for residues are behind schedule and additional NDA equipment necessary for WIPP validation has been ordered. Restart of residue disposition activities (i.e., Pipe-n-Go of ash) is now anticipated in the 4th quarter of FY 2000, versus the planned April 2000 restart. Oxide stabilization activities continue significantly ahead of schedule.

\section{Fy 2000 Cost/Schedule Performance - All Fund Types Cumulative to Date Status - $(\$ 000)$}

\begin{tabular}{|c|c|c|c|c|c|c|c|c|c|c|c|}
\hline \multirow{2}{*}{\multicolumn{2}{|c|}{ By PBS }} & \multicolumn{7}{|c|}{ FYTD } & \multicolumn{2}{|c|}{ 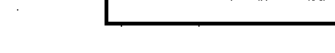 } & \multirow[b]{2}{*}{ EAC } \\
\hline & & BCws & BCWP & ACWP & sv & $\%$ & cv & $\%$ & PEM & FYSF & \\
\hline $\begin{array}{l}\text { WBS } 1.4 .5 \\
\text { PBS TP05 }\end{array}$ & $\begin{array}{l}\text { PFP } \\
\text { Deactivation }\end{array}$ & $\$ 85,336$ & $\$ 70,128$ & $\$ 80,292$ & $\$(15,208)$ & $-18 \%$ & $\$(10,164)$ & $-14 \%$ & $\$ 124,130$ & $\$ 121,908$ & $\$ 127,475$ \\
\hline & Total & $\$ 85,336$ & $\$ 70,128$ & $\$ 80,292$ & $\$(15,208)$ & $-18 \%$ & $\$(10,164)$ & $-14 \%$ & $\$ 124,130$ & $\$ 121,908$ & \$ 127,475 \\
\hline
\end{tabular}

RL-Directed costs (steam) are included in the PEM BCWS. 


\section{Cost/SChedule Performance Indices (MONTHLY AND FYTD)}

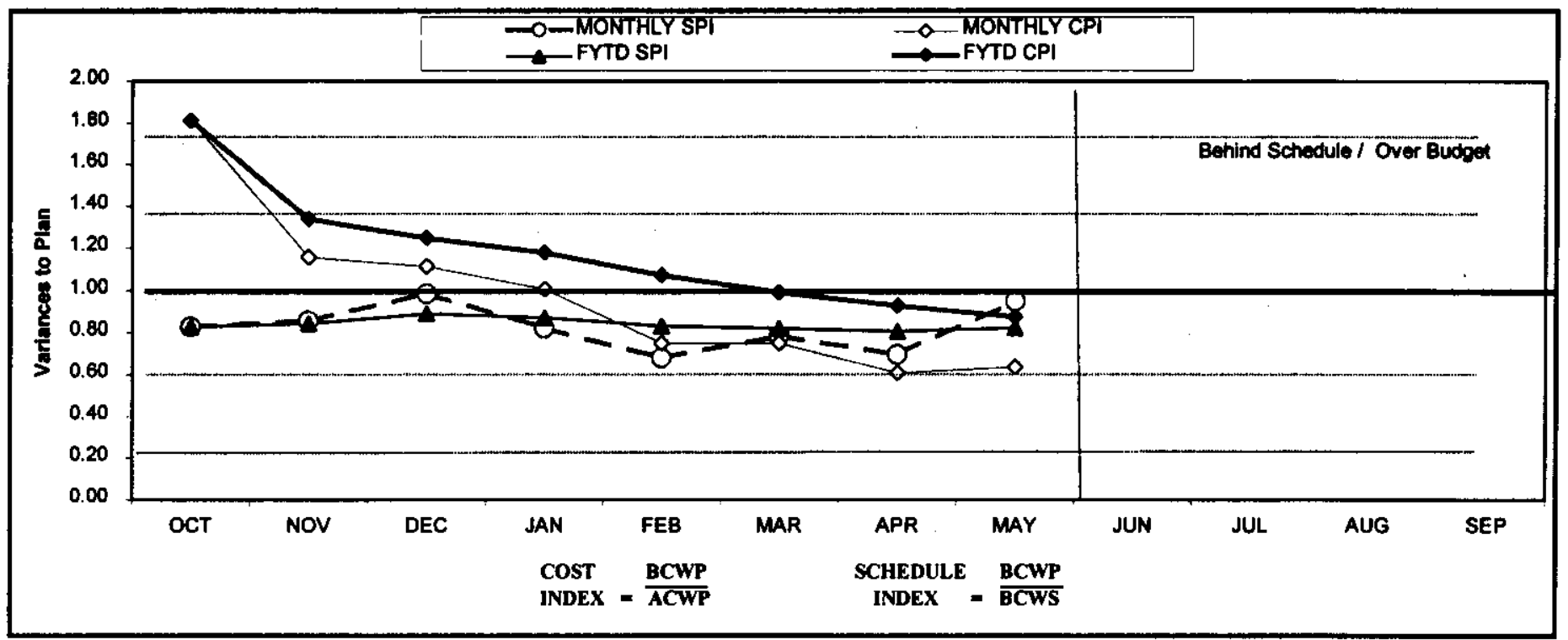

\begin{tabular}{|c|c|c|c|c|c|c|c|c|c|c|c|c|}
\hline FY2000 & OCT & NOV & Dxc & JAT & FEE & MAK & $\mathbf{A P R}$ & MAY & JUN & JUL & AUG & SEP \\
\hline MONIHLYSP & 0.83 & 0.85 & 0.98 & 0.82 & 0.68 & 0.78 & 0.70 & 0.95 & & & & \\
\hline MONIHLYCPI & T.81 & T.16 & T.T & 1.01 & 0.75 & 0.75 & 0.61 & 0.64 & & & & \\
\hline FYTDSPI & 0.83 & 0.84 & 0.89 & 0.87 & 0.83 & 0.82 & 0.81 & 0.82 & & & & \\
\hline FYTDCPI & T.8I & T.34 & $T .25$ & 1.18 & T.07 & 0.99 & 0.93 & 0.87 & & & & \\
\hline पONIHLYBCWS & 57,913 & 312,725 & उ9,999 & 310,540 & 311,128 & 313,401 & 39,632 & 39,999 & 38,755 & 39,170 & गा,ा6ा & 39,707 \\
\hline MONIHLYBCWP & 36,543 & 510,873 & 39,849 & 38,638 & 37,567 & \$TU,480 & 36,704 & 39,474 & & & & \\
\hline MONIHLY ACWP & 53,613 & 39,386 & 38,845 & 38,587 & 310,085 & $313, \% 1$ & 310,988 & 314,826 & & & & \\
\hline FYIDECWS & 37,913 & 320,636 & b0,695 & 31,177 & 352,305 & 365,706 & 375,338 & 385,336 & 394,091 & $\$ 103,262$ & $\$ 114,423$ & 3124,130 \\
\hline FYTDBCWP & 56,543 & \$17, it: & 281,2065 & 355,903 & 343,470 & 553,950 & 360,654 & 370,128 & & & & \\
\hline FYID ACWP & \$\$,6ा3 & S1Lg & & & $2 \ln x$ & 35,477 & $3 \times 55,465$ & 380,292 & & & & \\
\hline
\end{tabular}

\section{COST VARIANCE ANALYSIS: $(-\$ 10.2 \mathrm{M})$}

WBS/PBS

\subsection{3/TP05}

\section{Title}

\section{Stabilization of Nuclear Materials (-\$5.7M)}

Description and Cause: The unfavorable cost variance is due primarily increased plant support needed for procurement and installation of the $\mathrm{Mg}(\mathrm{OH})_{2}$ glovebox and equipment, and other construction activities, and use of subcontract staff augmentation.

Impact: Construction not started on time; cost overruns can hurt overall plant project funding. Corrective Action: Acceleration of schedule for procurement, construction and startup has been implemented.

\subsection{5/TP05 Transition PFP (-\$0.8M)}

Description and Cause: The unfavorable cost variance is the result of increased costs for lab analysis of tank 241-Z-361 samples as well as carryover work scope not yet reflected in the baseline. Laboratory Analysis has shown tank values exceed $50 \mathrm{ppm}$ of Polychlorinated Biphenyl PCBs. Evaluation as to disposition is underway.

Impact: Continuing work scope will result in a cost over run for this activity, savings from elsewhere within the Nuclear Materials Stabilization Project will be required to offset the overrun. 
Corrective Action: Approve and implement baseline change request to reflect FY 1999 carryover work scope. If PCBs are found to exceed allowable limits, a separate change request may be required to incorporate the additional special waste handling requirements into the baseline. Identify cost savings from elsewhere within the NMSP to offset this overrun.

\title{
1.4.5.1.12/TP05 PFP Fee Allocation (-\$.9M)
}

Description and Cause: Unfavorable cost variance due to point adjustment $(-\$ 471 \mathrm{~K})$ in May to adjust for delay in staff hiring ramp-up at the beginning of FY 2000. An increase in the fee accrual rate from $90 \%$ to $100 \%$ also is a contributory factor.

Impact: No impact.

Corrective Action: None required.

\subsubsection{5/TP12}

NMS Project Management/Mentoring (-\$1.9M)

Description and Cause: The change request to realign the TP12 (Transition Project

Management) budget between the Nuclear Material Stabilization Project and the River Corridor Project is still in process; therefore the NMSP budget is understated resulting in a negative cost variance.

Impact: None

Corrective Action: DOE-RL approval. Implementation of change request reflecting the PHMC restructuring.

\section{SCHEDULE VARIANCE ANALYSIS: $(-\$ 15.2 \mathrm{M})$}

\section{WBS/PBS}

\subsection{4/TP05}

\section{Title}

\author{
Disposition of Nuclear Material (-\$10.3M)
}

Description and Cause: The unfavorable schedule variance is primarily due to delays in Line Item Project W-460, Plutonium Stabilization and Packaging System, definitive design and construction. Facility construction modifications have not yet started as scheduled, due to deviations to the Definitive Design, required changes to the NEPA Supplement Analysis and approval of the Notice of Construction (NOC) by the Washington State Department of Health (WSDOH).

Impact: Potential delay in the startup of the Bagless Transfer and Stabilization system in 2736-ZB, which can impact stabilization activities in FY 2001.

Corrective Action: To assist in the recovery, a second BTS unit is being installed in the 234-5Z facility, which will enable BTS unit operation in FY 2000 as originally planned. Project W-460 management and WSDOH staffs are aggressively working to approve the NOC, which will enable construction to begin.

\subsection{3/TP05 Stabilize SNM (-\$4.8M)}

Description and Cause: The unfavorable schedule variance is due primarily to the behind schedule status on residues and solution stabilization activities. Solution stabilization construction activities are two months behind schedule, with startup now planned for September 2000. Also, restart activities for cementation are behind schedule due to the need for additional 
Nondestructive Assay (NDA) equipment necessary for WIPP validation. Restart of cementation of Sand, Slag, and Crucible (SS\&C) material processing is now anticipated in late July 2000, versus the April 2000 restart. Oxide stabilization activities continue significantly ahead of schedule.

Impact: Potential delay in both restart of cementation and startup of $\mathrm{Mg}(\mathrm{OH})_{2}$ precipitation processing for solution stabilization; anticipate schedule recovery by the end of FY2000. Corrective Action: An aggressive recovery plan has been developed for both solution stabilization and cementation activities to commence operations in September and July respectively. Plans are also in place to stabilize solutions and residues exceeding baseline commitments even with a late processing start. NDA equipment has been ordered and NMSP is working with the WM Project to meet the Waste Isolation Pilot Plant (WIPP) certification.

\section{ISSUES}

\section{Technical Issues}

Implementation of supercritical fluid extraction technology for moisture measurements will require installation of a new glovebox in room 235-B.

Impact (s): This installation will require several hundred thousand dollars more than budgeted for procurement and installation and result in several weeks of processing impact during the installation.

Corrective Action: The Baseline Change Request (BCR) has been completed.

Installation in 234-5Z BTS glovebox is scheduled for completion by September 30, 2000.

\section{Solution Stabilization Readiness Assessment has been replaced with an Operations} Readiness Review (ORR).

Impact (s): Impact to schedule. Delay of activities could impact Performance Incentive. Corrective Action: Plan of Action has been submitted to DOE-RL for approval. Draft Master Safety Analysis (MSA) checklist and startup plans have been developed.

Seismic issues related to the material storage cage in room 638.

Impact (s): Higher exposure than normal to vault operators

Corrective Action: Completed recovery plan. Install new seismically qualified racks in room 638 cage. Not currently funded.

Lack of certified shipping containers in the DOE Complex to meet PFP schedules.

Impact(s): Prohibits shipment of nuclear materials that cannot go to either WIPP or

DOT-6M containers (i.e., Pu standards for re-certification, shipment of reactive materials for processing elsewhere, etc.).

Corrective Action: Work with the DOE Complex to certify containers to meet PFP shipping needs (i.e., 9975 container to be re-certified in June 2000, etc.).

Jointly resolve issues associated with precipitation process. Concentration, Density, Filtrate Handling (permitting of 241-Z to handle heavy metals), discards directly to tank farms.

Impact(s): Concentration/density issue may significantly impact the number of containers to be stored under final disposition. The $241-Z$ permitting issue, if not 
resolved, can impact the plant's ability to discard solution waste to tank farms resulting from the $\mathrm{Mg}(\mathrm{OH})_{2}$ precipitation processing of plutonium solutions.

Corrective Action: Concentration/density issue is being worked through laboratory testing at both Pacific Northwest National Laboratory (PNNL) and PFP's Plutonium Process Support Laboratories. Appropriate actions will be taken according to laboratory results. Also, project management has worked with the Tank D-5/D-8 readiness team to ensure that these tanks are ready to support solution stabilization processing startup as scheduled.

Equipment for processing $\mathrm{Pu}$ inside the $\mathrm{Mg}(\mathrm{OH})_{2}$ gloveboxes needs to be defined and approved by Operations before glovebox size can be finalized.

Impact(s): Gloveboxes cannot be ordered until size is finalized.

Corrective Action: Use mockup and daily meetings with Operations to finalize the internal arrangement of the gloveboxes to the point where a size can be determined and the gloveboxes ordered.

Solution Stabilization Readiness Assessment has been replaced with an ORR.

Impact(s): Impact to schedule. Delay of activities could impact Performance Incentive. Corrective Action: Detailed evaluation conducted to identify activities and resources to perform scope of work. Finalizing list of activities for incorporation into project schedule.

Criticality analysis for storage of drums with Pipe Overpack Containers (POCs) at the Central Waste Complex (CWC). (Currently unfunded)

Impact(s): Drums with POCs will not be shipped to the CWC. The Cementation process will begin using a 90-day storage pad until permitted storage is approved by Ecology.

Corrective Action: A statement of work has been written by the Central Waste Complex safety representative for development of a criticality credibility analysis using an analysis similar to that used at Rocky Flats to support POC drum storage at the CWC.

\section{DOE/Regulator/External Issues}

- $\quad$ RCRA Permitting Part A revision for adding ignitability waste code was submitted to Ecology in support of Cementation startup.

- $\quad$ RCRA Permitting in support of Pipe-N-Go:

- A revised Notice of Intent (NOI) to define storage locations at PFP was released for public review

- $\quad$ Revised Part A to provide permitted storage at PFP will be transmitted to Ecology in May 2000

- Update interface agreement between PFP and Waste Management to define requirements and responsibilities to support CWC and Waste Isolation Pilot Plant acceptance of packaged residues.

- PFP request to DOE-RL to contact Westinghouse Savannah River with respect to accelerated delivery of the additional BTS unit. 
- Continue work with Rocky Flats to procure containers (Pipe-n-Go) to support PFP Residue Stabilization without the need for another procurement action.

\section{Baseline Change Requests Currently in Process}

\begin{tabular}{|c|c|c|c|c|c|c|c|c|c|}
\hline $\begin{array}{l}\text { PROJECT } \\
\text { CHANGE } \\
\text { NUMBER }\end{array}$ & $\begin{array}{l}\text { DATE } \\
\text { ORIGIN. }\end{array}$ & BCR TITLE & $\begin{array}{c}\text { FYOO } \\
\text { COST } \\
\text { IMPACT } \\
\text { S0000 }\end{array}$ & SCH & TECH & $\underset{\text { CCB }}{\text { DATE TO }}$ & $\underset{\text { APR'VD }}{\text { CCB }}$ & $\underset{\mathbf{A P R} \text { 'VD }}{\mathbf{R L}}$ & $\begin{array}{l}\text { CURRENT } \\
\text { STATUS }\end{array}$ \\
\hline FSP-2000-001 & 13-Oct-99 & $\begin{array}{l}\text { Delete TRP-99-419, Complete } \\
\text { Install. of Production Scale Vertical } \\
\text { Calciner }\end{array}$ & so & & & & & & Deleted \\
\hline FSP-2000-004 & 23-Nov-99 & $\begin{array}{l}\text { PFP Test Polycube Stabilization via } \\
\text { Muffle Furnace }\end{array}$ & so & $\mathrm{x}$ & $\mathbf{x}$ & 17-Feb-00 & 17-Feb-00 & 28-Mar-00 & RL approved \\
\hline FSP-2000-045 & $30-$ Nov -99 & $\begin{array}{l}\text { Implement PFP Int Proj Mgmt Plan } \\
\text { Addendum I }\end{array}$ & \$o & $\mathbf{x}$ & $\mathbf{x}$ & & & & In work at PFP \\
\hline FSP-2000-043 & 5-May- 00 & $\begin{array}{l}\text { PFP Remote Controlled Video } \\
\text { System }\end{array}$ & so & & & & & & $\begin{array}{l}\text { On hold for } \\
\text { funding }\end{array}$ \\
\hline FSP-2000-049 & 7-Jun-00 & $\begin{array}{l}\text { Revision to NMS Milestone TRP-00 } \\
13\end{array}$ & so & & & & & & \\
\hline FSP-2000-050 & 8-Jun- 00 & $\begin{array}{l}\text { PFP Project W-460 Purchase } \\
\text { (Calorimeter \& Outer Can Welder) }\end{array}$ & so & & & & & & \\
\hline FSP-2000-051 & 8-Jun-00 & $\begin{array}{l}\text { HEPA Filter Vulnerability } \\
\text { Assessment }\end{array}$ & so & & & & & & \\
\hline FSP-2000-053 & 13-Jun-00 & $\begin{array}{l}\text { Accelerated Installation of PFP } \\
\text { Backflow Preventers }\end{array}$ & so & & & & & & \\
\hline FSP-2000-011 & 27-Dec-99 & $\begin{array}{l}\text { Adjusted PFP Cementation } \\
\text { Processing to include Sand, Slag and } \\
\text { Crucible }\end{array}$ & \$o & $\mathbf{x}$ & $\mathbf{x}$ & 14-Jan-00 & 18-Jan-00 & 17 -Feb-00 & Implemented \\
\hline FSP-2000-025 & 10-Mar-00 & PFP Replacement Transformer & $\$ 992$ & $\mathbf{x}$ & & 27-Mar-00 & 27-Mar-00 & Not Req'd & Implemented \\
\hline FSP-2000-029 & 26-Jan-00 & PFP FY2000 Funds Reduction & $(\$ 5,565)$ & $\overline{\mathbf{x}}$ & & 9-Mar-00 & 23-Mar-00 & 16-May-00 & RL approved \\
\hline FSP-2000-032 & 22-Mar-00 & PFP 2nd Bagless Transfer System & $\$ 890$ & $\bar{X}$ & $\overline{\mathbf{X}}$ & 29-Mar-00 & 7-Apr-00 & 16-Jun-00 & Implemented \\
\hline FSP-2000-035 & 3-Apr-00 & PFF Carty-over Workscope & $\$ 620$ & $\overline{\mathbf{X}}$ & $\bar{X}$ & 2-May-00 & 2-May-00 & Not Req'd & Implemented \\
\hline
\end{tabular}

\section{Milestone ACHIEVEMENT}

\begin{tabular}{|c|c|c|c|c|c|c|c|c|}
\hline \multirow[b]{2}{*}{ MILESTONE TYPE } & \multicolumn{4}{|c|}{ FISCAL YEAR-TO-DATE } & \multicolumn{3}{|c|}{ REMAINING SCHEDULED } & \multirow[b]{2}{*}{$\begin{array}{c}\text { TOTAL } \\
\text { FY } \\
2000\end{array}$} \\
\hline & $\begin{array}{c}\text { Completed } \\
\text { Early }\end{array}$ & $\begin{array}{c}\text { Completed } \\
\text { On } \\
\text { Schedule }\end{array}$ & $\begin{array}{c}\text { Completed } \\
\text { Late }\end{array}$ & Overdue & $\begin{array}{c}\text { Forecast } \\
\text { Early }\end{array}$ & $\begin{array}{l}\text { Forecast } \\
\text { On } \\
\text { Schedule }\end{array}$ & $\begin{array}{c}\text { Forecast } \\
\text { Late }\end{array}$ & \\
\hline Enforceable Agreement & 73 & 2 & 0 & & 0 & 70 & 0 & 26 \\
\hline DOE-HQ & 0 & 0 & 0 & 0 & 0 & $\overline{2}$ & 0 & 2 \\
\hline RL & 5 & 5 & 3 & 0 & 0 & $\sqrt{3}$ & 0 & 26 \\
\hline Total Project & $\overline{18}$ & $\overline{7}$ & 3 & 1 & $\overline{0}$ & 25 & $\overline{0}$ & 54 \\
\hline
\end{tabular}


Tri-Party Agreement Milestone M-15-37A (TRP-00-501), "Deliver.Two (2)

Tank Z-241-Z-361 Core Samples to 222-S", due 10/30/99

- $\quad$ Completed 1 month early (9/28/99)

Tri-Party Agreement Milestone (TRP-00-511), "Deliver Two (2)

Tank 241-Z-361 Core Sample Validated Data Packages to EPA", due 5/31/00

- Completed On Schedule

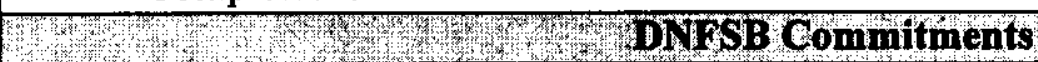
DNFSB Milestone IP-113 (TRP-00-500), "Install 2 LANL
Pyrolysis Units for Stabilization of Polycubes at PFP", due 12/31/99

- A BCR to remove pyrolysis stabilization of polycubes and implement thermal stabilization in its stead has been approved by $\mathrm{RL}$ and implemented into the baseline.

\section{MILESTONE EXCEPTION REPORT}

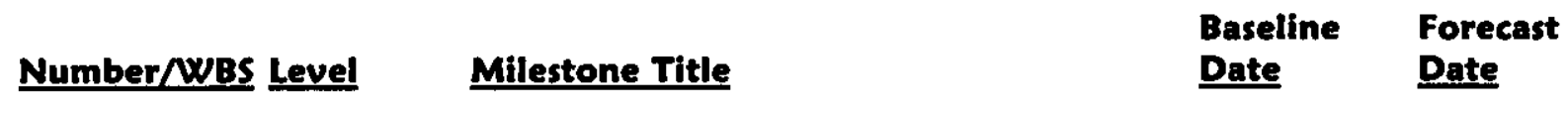

\section{OVerdue - 4}

TRP-00-103 RL

\subsection{6}

Submit Hanford Materials Forecast to

$05 / 15 / 00$

$06 / 02 / 00$

Cause: RL established a later completion date of June 16.

Corrective Action: A BCR has been prepared to change the baseline date to June 16 . The milestone was completed on June 2.

$\begin{array}{llll}\text { TRP-00-504 RL } & \text { Restart Cementation Operations } & 04 / 21 / 00 & \text { FY } 2001\end{array}$

\subsection{5}

Cause: Stabilization processing has been re-sequenced.

Corrective Action: None, as the global stabilization end point will remain the same.

\begin{tabular}{|c|c|}
\hline $\begin{array}{l}\text { TRP-00-500 HQ } \\
1.4 .5\end{array}$ & $\begin{array}{l}\text { Install Two LANL Pyrolysis Units for } \\
\text { Stabilization of Polycubes }\end{array}$ \\
\hline
\end{tabular}

Cause: See DNFSB Commitment above.

Corrective Action: A BCR to remove pyrolysis stabilization of polycubes and implement thermal stabilization in its stead has been approved by RL and implemented into the baseline. However, this is a HQ milestone and cannot be removed from the list.

TRP-00-510 RL Complete Annual Revision to IPMP 05/31/00 07/31/00

\subsection{5}

Cause: Comment resolution has taken longer than anticipated.

Corrective Action: None. 


\section{FY 1999 OVERDUE - 2}

\section{TRP-99-419 RL \\ Complete Installation of Production \\ $09 / 30 / 99$ \\ Proposed \\ 1.4.5 \\ Scale Vertical Calciner \\ Deletion}

Cause: The production scale vertical calciner has been replaced with the Magnesium Hydroxide Precipitation process.

Impact: No impact. This milestone is obsolete.

Corrective Action: Since installation and testing of the production scale vertical calciner is an

EM-65 Management Commitment, the Department of Energy, Richland Office (DOE-RL) change control process cannot remove this milestone.
TRP-99-500 HQ
Complete Installation \& Testing of
09/30/99 Proposed
1.4.5
Production Vertical Calciner
Deletion

Cause: The production scale vertical calciner has been replaced with the Magnesium Hydroxide Precipitation process.

Impact: No impact. This milestone is obsolete.

Corrective Action: Since this milestone is a DOE-HQ milestone and is part of the DOE-HQ 1998 DNFSB Recommendation 94-1 Implementation Plan, the Department of Energy, Richland Office change control process cannot remove this milestone. However, this milestone will be removed upon approval of the revised DOE-HQ DNFSB Recommendation 94-1 Implementation Plan.

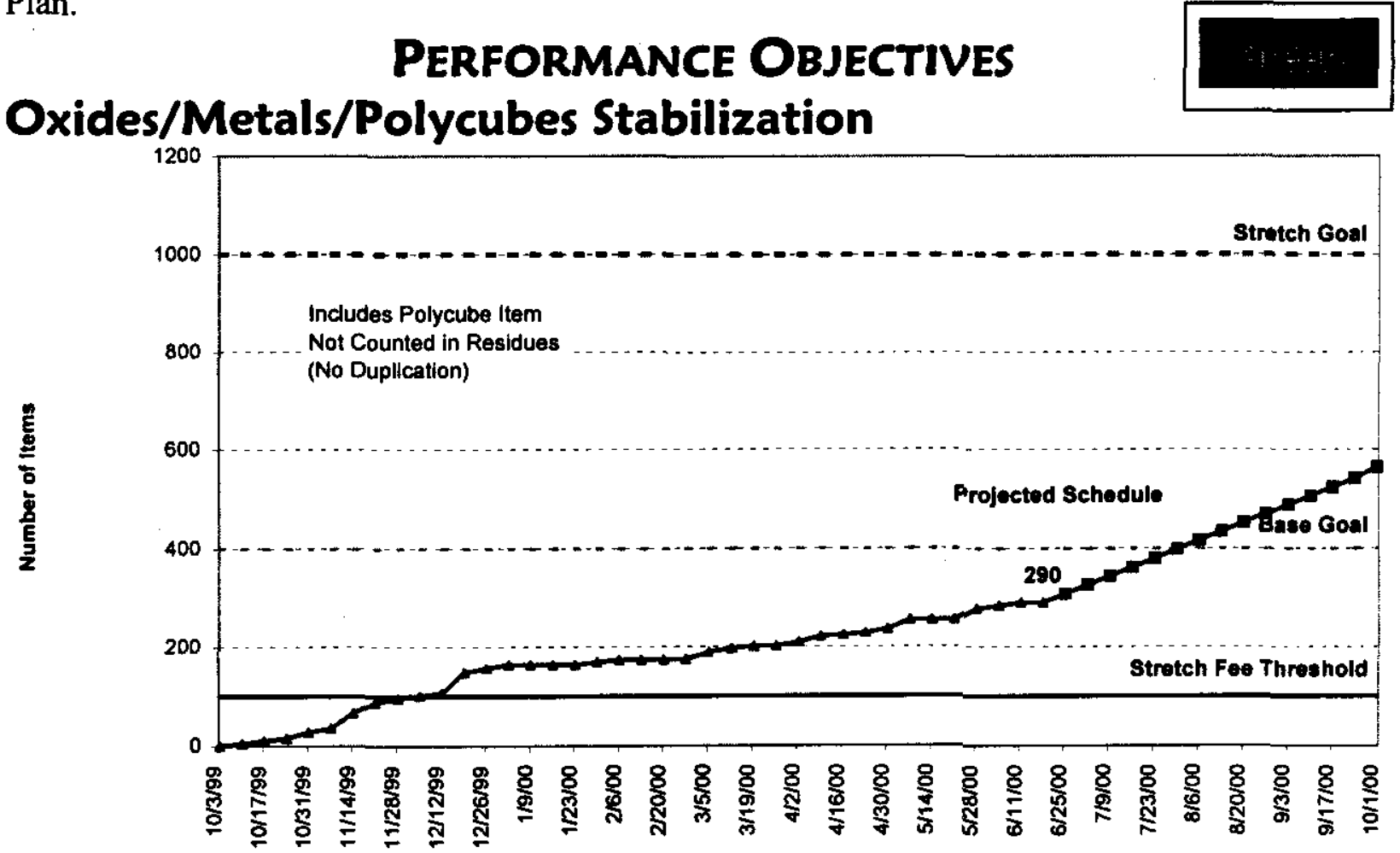

\begin{tabular}{|c|c|c|c|c|c|c|c|c|c|c|c|c|c|c|c|c|c|c|c|c|c|c|c|c|c|c|c|}
\hline & $10 / 3$ & $10 / 17$ & $10 / 31$ & 111/14 & 11120 & $12 / 12$ & $12 / 28$ & 10 & $1 / 23$ & 200 & $2 / 20$ & $3 / 5$ & 3/19 & $4 / 2$ & 40 & $4 / 23$ & $5 / 7$ & $\sqrt[5]{21}$ & $8 / 4$ & $2 / 8$ & $7 / 2$ & $7 / 10$ & $7 / 300$ & $8 / 13$ & a/27i & $\% 10$ & $9 / 24$ \\
\hline Oxdides $\mathrm{s}$ & 1000 & 1000 & 1000 & 1000 & 1000 & 1000 & 1000 & 1000 & 1000 & 1000 & 1000 & 1000 & 1000 & 1000 & 1000 & 10001 & 1000 & 1000 & 1000 & 1000 & $1000: 1$ & 1000 & $1000: 1$ & 10001 & 1000 & 1000 & 1000 \\
\hline Oxdoes Base Goul & 400.0 & 400.0 & 400.0 & 400.0 & 400.0 & 400.0 & 400.0 & 400.0 & 400.0 & 400.0 & 400.0 & 400.0 & 400.0 & 400.0 & 400.0 & 400.0 & $400.0^{\prime}$ & 400.0 & 400.0 & 400.0 & 400.014 & 400.0 & 400.0 & 400.014 & 100.0 & 400.0 & 400.0 \\
\hline Oxdodes Actual & 0 & 10 & 27 & 87 & 85 & 107 & 157 & 164 & 104 & 174 & 174 & 180 & 201 & 200 & 221 & 228 & 255 & 255 & 284 & 290 & & & & & & & \\
\hline Oxtaos Propect & & & & & & & & & & & & & & & & & & & & 290 & 326 & 362 & 398 & 434 & 470 & 508 & 542 \\
\hline Siritch Foe Threshold & 100 & 100 & 100 & 100 & 100 & 100 & 100 & 100 & 400 & 100 & 100 & 100 & 100 & 100 & 100 & 100 & 100 & 100 & 100 & 100 & 100 & 100 & 100 & 100 & 100 & 100 & 100 \\
\hline
\end{tabular}




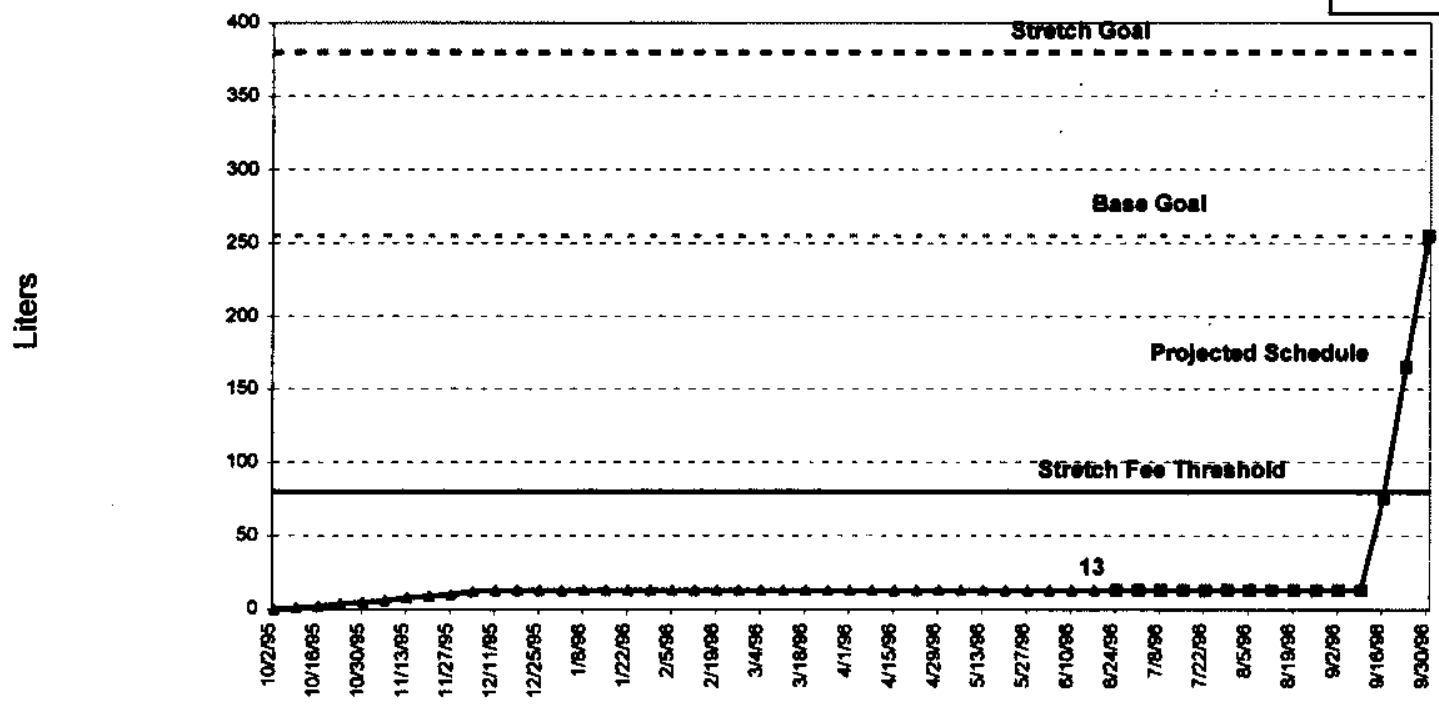

\begin{tabular}{|c|c|c|c|c|c|c|c|c|c|c|c|c|c|c|c|c|c|c|c|c|c|}
\hline & $10 / 2$ & 10/23 & $11 / 8$ & $\mid 11 / 27$ & [12/11 & $1 / 1$ & 1/15 & $2 / 5$ & $2 / 19$ & $3 / 11$ & $3 / 25$ & $4 / 45$ & 429 & $5 / 20$ & $\mathbf{a} / 3$ & 6/24 & $7 / 8$ & 7729 & 8/12 & $9 / 2$ & /18 \\
\hline Solutions Stretch Gos & 380 & 380 & 380 & 380 & 380 & 300 & 380 & 300 & 380 & 380 & 380 & 380 & 380 & 380 & 300 & 300 & 360 & 360 & 380 & 300 & 360 \\
\hline Soluturtons Base Goel & 255.0 & 255.0 & 255.0 & 255.0 & 256.0 & 255.02 & 255.0 & 255.02 & 255.02 & 255.02 & 255.02 & 255.0 & 255.0 & 255.02 & 255.0 & 255.02 & 255.0 & 255.0 & 255.0 & 255.0 & 255.0 \\
\hline Solutions Actual & 0 & 4 & - & 10 & 13 & 13 & 13 & 13 & 13 & 43 & 13 & 13 & 13 & 13 & 13 & & & & & & \\
\hline Solutions Projected Schedule & & & & & & & & & & & & & & & & 13 & 13 & 13 & 13 & 13 & 73.5 \\
\hline Strotch Feo Throshold & 80 & 80 & 80 & 80 & 80 & 80 & 80 & 80 & 80 & 80 & 80 & 80 & 80 & 80 & 80 & 80 & 80 & 80 & 80 & 80 & 80 \\
\hline
\end{tabular}

Aggressively pursuing construction completion in support of stabilization activities.

\section{Residues Stabilization}

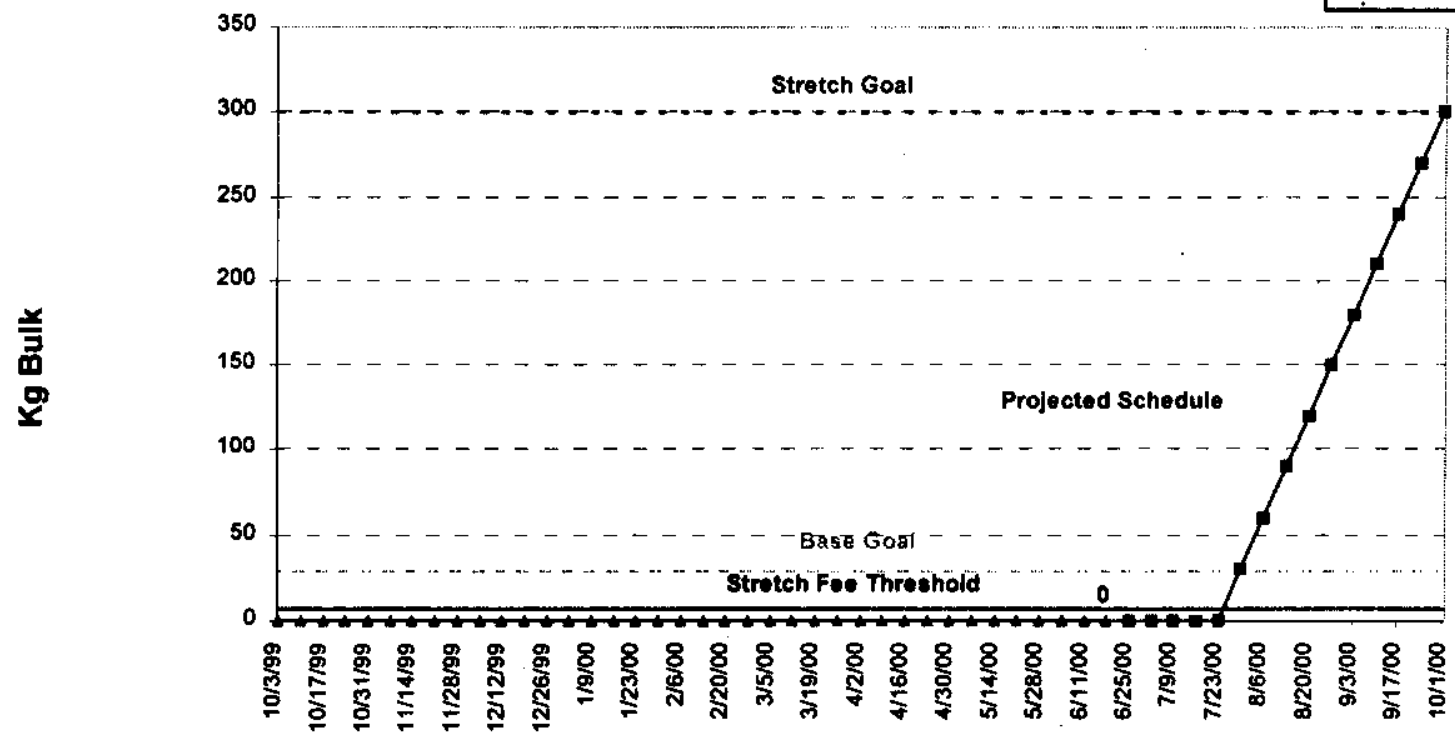

\begin{tabular}{|c|c|c|c|c|c|c|c|c|c|c|c|c|c|c|c|c|c|c|c|c|c|}
\hline & 1013 & 1024 & $11 \pi$ & $11 / 28$ & $\mid 12 / 12$ & $1 / 2$ & $1 / 16$ & $2 / 6$ & 220 & 3/12 & $\mid 3226$ & $|4 / 16|$ & $4 / 30$ & $5 / 21$ & $0 / 4$ & 625 & $7 \%$ & 780 & $8 / 13$ & 83 & : 117 \\
\hline Residuos Strotch Goed & 300 & 300 & 300 & 300 & 300 & 300 & 300 & 300 & 300 & 300 & 300 & 300 & 300 & 300 & 300 & 300 & 300 & 300 & 300 & 300 & 300 \\
\hline Residues Base Goal & 29 & 29 & 28 & 29 & 29 & 29 & 29 & 20 & 29 & 29 & 29 & 29 & 29 & 28 & 29 & 29 & 29 & 29 & 29 & 28 & 28 \\
\hline Residues Actual & 0 & 0 & 0 & 0 & 0 & 0 & 0 & 0 & 0 & 0 & 0 & 0 & 0 & 0 & 0 & & & & & & \\
\hline Residues Projected Scheodule & & & & & & & & & & & & & & & & 01 & $\overline{0}$ & 30 & $90^{\circ}$ & 180 & 240 \\
\hline Suretch Foo Threshold & 7 & 7 & 7 & $\overline{7}$ & 7 & 7 & 7 & 7 & 7 & 7 & 7 & 7 & 7 & 7 & 7 & 7 & 7 & 7 & 7 & 7 & 7 \\
\hline
\end{tabular}

Update baseline schedule for new cementation start-up date and adjust ash schedule for preparatory work. 


\section{KEY INTEGRATION ACTIVITIES}

- Working on interface agreement between PFP and Waste Management to define requirements and responsibilities to support Central Waste Complex (CWC) and WIPP acceptance of packaged residues.

- $\quad$ Continue work with Rocky Flats to procure containers (Pipe-n-Go) to support PFP Residue Stabilization without the need for another procurement action. Work continues with Rocky Flats to reach a joint resolution to PFP stabilization heating process.

- Joint PNNL/Plutonium Process Support Laboratories (PPSL) $\mathrm{Mg}(\mathrm{OH})_{2}$ continues:

- $\quad$ Status meeting with PNNL, PFP \& DOE RL.

- $\quad$ PPSL preparing to conduct scale testing with test set up developed by PNNL.

- Downloaded solutions (1 product receiver (PR) container) in room 227 to support Phase 2 testing by PPSL. 


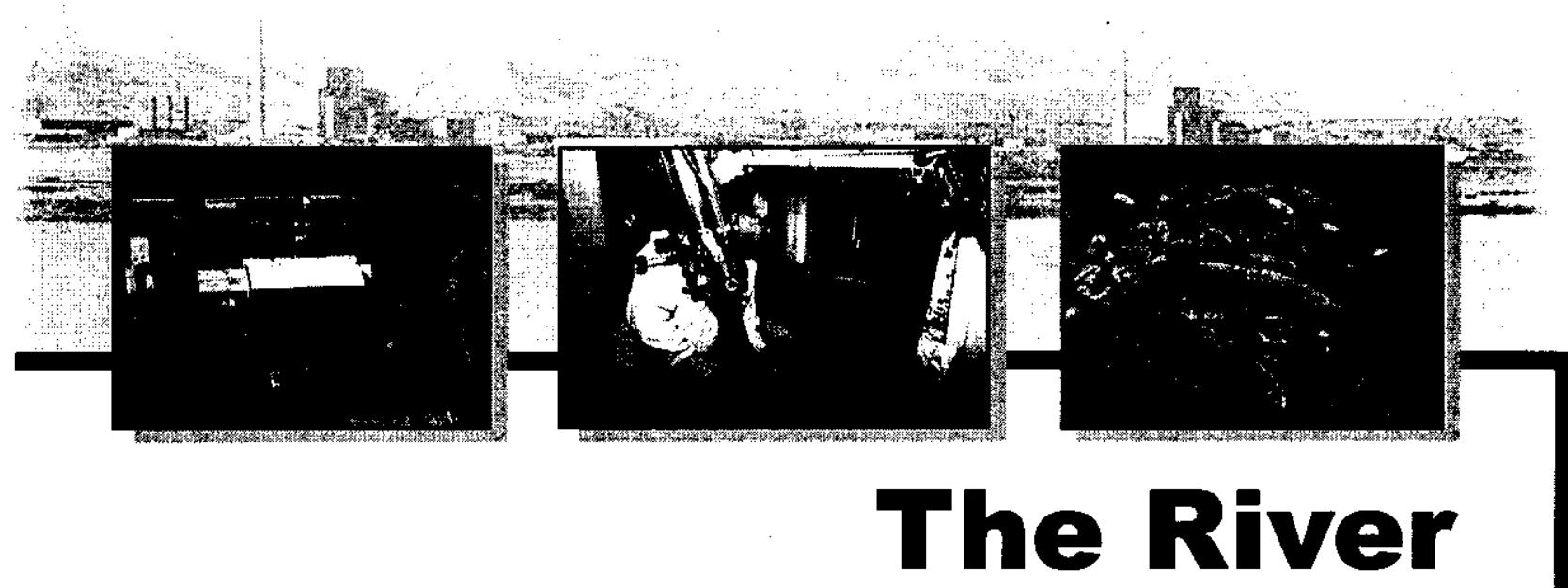

Restoring the river corridor is one of the outcomes Hanford must focus on to move forward with cleanup. The PHMC supports this outcome with activities such as moving the spent nuclear fuel, cleaning up the waste sites, and taking down surplus facilities. Projects supporting this effort are Facility Stabilization (River Corridor), Spent Nuclear Fuel, and Science \& Technology (EM-50) activities. 


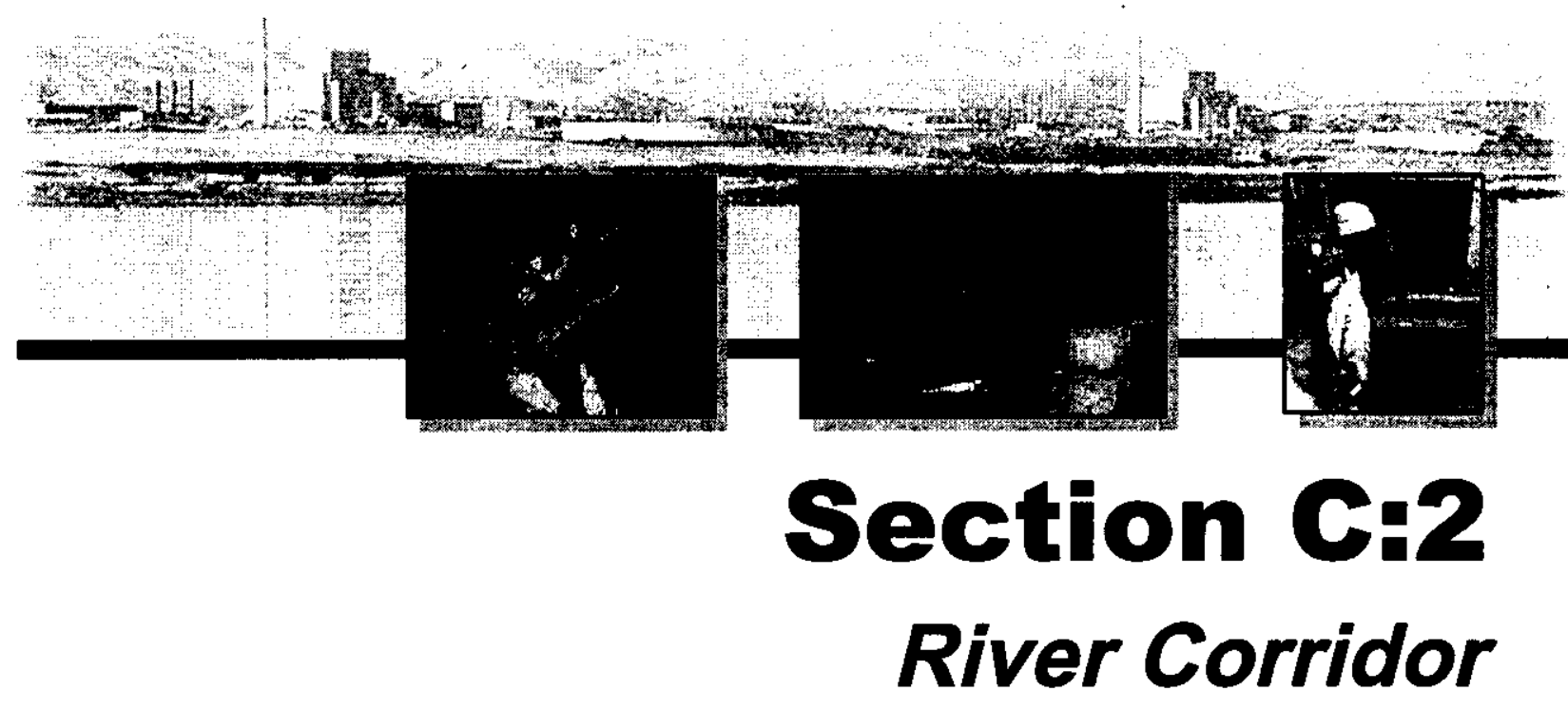

PROJECT MANAGERS

P.M. Knollmeyer, RL (509) 376-7435

N. Boyter, FH (509) 373-3725 


\section{SUMMARY}

The River Corridor Project consists of the following projects: 300 Area Liquid Effluent Facility (LEF) WBS 1.2.3.2, Project Baseline Summary (PBS) WM05; B-Plant, WBS 1.4.1, PBS TP01; 300 Area/Special Nuclear Materials, WBS 1.4.4, PBS TP04; Transition Project Management, WBS 1.4.6, PBS TP12; Accelerated Deactivation, WBS 1.4.8, PBS TP10; 324/327 Facility Transition, WBS 1.4.10, PBS TP08; and Hanford Surplus Facility Program (300 Area Revitalization), WBS 1.4.11, PBS TP14.

PBS WM05 is divided between WBS 1.2.3.1, Liquid Effluents (200 LEF) and WBS 1.2.3.2, 310 TEDF/340 Facility (300 LEF). The 310 TEDF/340 Facility work scope is now included in the River Corridor Project, whereas the Liquid Effluents (200 LEF) work scope has remained in Waste Management. For the purpose of performance analysis, PBS WM05 is reported in its entirety in the Waste Management Project, which has the majority of the work scope and funding incorporated in their baseline.

NOTE: Unless otherwise noted, the Safety, Conduct of Operations, Milestone Achievement, Metrics and Cost/Schedule data contained herein is as of May 31, 2000. All other information is as of June 22, 2000.

Good progress was made toward closeout of the actions required by the B Plant transfer Memorandum of Agreement (MOA). There are a few issues remaining, to include aerosol challenge test of the north filter train and restart of the B Plant exhaust system by July 28, 2000 .

Progress continues toward Accelerated Deactivation of the 327 Facility with the removal of Legacy Waste Container Leg 05 and four concrete lined drums of legacy waste buckets. Additionally, seven Lead Lined Drums were loaded with waste buckets, dry storage samples, fissile inventory and pin tubes. The last seven cans of retrievable non-fissile material and four fissile cans were removed from dry storage. All remaining fissile pieces from D Cell (4.0 grams) and $\mathrm{E}$ Cell ( 4.5 grams) were transferred to $\mathrm{F}$ cell for consolidation.

Twelve grout containers of the planned seventeen have now been shipped to the Low-level Burial Grounds in the 200 Area. Shipment of this waste is critical to meeting TPA milestone M89-02, "Complete Removal of 324 Building Radiochemical Engineering Cell (REC) B Cell Mixed Waste (MW) and Equipment," due November 2000.

The Accelerated Deactivation project is making good progress in planning for the disposition of approximately 1,865 metric tons (MT) of Hanford Unirradiated Uranium. Review of the billet Safety Analysis Report for Packaging has been initiated by DOE-HQ for approval. DOE-RL review of the Environmental Assessment has been completed. If funded and regulatory agreement is received, disposition of the Uranium fuel elements will occur in the last quarter of FY 2000. Concurrently, Phase I activities to prepare uranium billets and UO3 T-hoppers for shipment are continuing.

Fiscal-year-to-date milestone performance (EA, DOE-HQ, and RL) shows that four of five 
milestones ( 80 percent) were completed on or ahead of schedule and one milestone is overdue. The Milestone Achievement details, found following cost and schedule variance analysis, provide further information on all milestone types.

\section{ACCOMPLISHMENTS}

The Dispersible Removal System (DRS) robot has been delivered and tested, and training is complete in support of the $324 \mathrm{~B}$ Cell Cleanout. The new robotic crawling device was designed and fabricated by ROV Technologies of Vernon, VA. The DRS will support removal of dispersible contamination from the 324 B Cell sump, trench and floor.

Shipment of the 324 Building's 12th grout container from the 17-container campaign is now complete. Repackaging of the mixed waste grout containers is $60 \%$ complete.

The 300 Area Liquid Effluent Facility received and processed eleven 33-gallon drums of sodium hydroxide, which results in avoidance of a $\$ 31.6 \mathrm{~K}$ disposal cost. Additionally, eight 55-gallon drums of sulfuric acid were unloaded into the 310 Facility sulfuric acid storage tank. This acid was excess product from the 200 Area Effluent Treatment Facility. Use of the excess acid will eliminate the need for disposal of the product as hazardous waste and result in a total savings of $\$ 108 \mathrm{~K}$.

Legacy Waste Container Leg 05 and four concrete lined drums of legacy waste buckets were shipped from the 327 Building to the Central Waste Complex for storage. Additionally, seven Lead Lined Drums were loaded with waste buckets, dry storage samples, fissile inventory and pin tubes. The last 7 cans of retrievable non-fissile material and four fissile cans were removed from dry storage. All remaining fissile pieces from D Cell (4.0 grams) and E Cell (4.5 grams) were transferred to $\mathrm{F}$ cell for consolidation.

Most activities are complete in support of closeout of the B Plant Memorandum of Agreement. There are a few issues remaining, to include the aerosol challenge test of the north filter train and restart of the B Plant exhaust system by July $28,2000$.

Reviews with the 300 Accelerated Closure Plan (ACP) Board of Directors and an Independent Cost Estimating (ICE) team were held on May 25 and June 12 and 13 respectively. Both reviews were well received and specific feedback was provided. Comments generated by the review are being incorporated into the $300 \mathrm{ACP}$. The plan is on schedule to be transmitted to RL on June $29,2000$.

An Advance Work Authorization for $\$ 295 \mathrm{~K}$ supporting Uranium Disposition was approved. The AWA will fund painting of the T-Hoppers, Criticality Safety Evaluation Report reviews, and initial shipments of T-Hoppers to Portsmouth, Ohio.

The Interim Safety Basis, Interim Operational Safety Requirements, and hazard classification documents for the Fuel Supply Shutdown facility were approved by RL. 


\section{SAFETY}

Significant decreases in Occupational Safety and Health Act (OSHA) recordable case rate and in DOE Safety Cost Index have recently occurred. The project has exceeded 750,000 hours without an OSHA recordable. The project has an overall green rating - stable at excellent rates. 

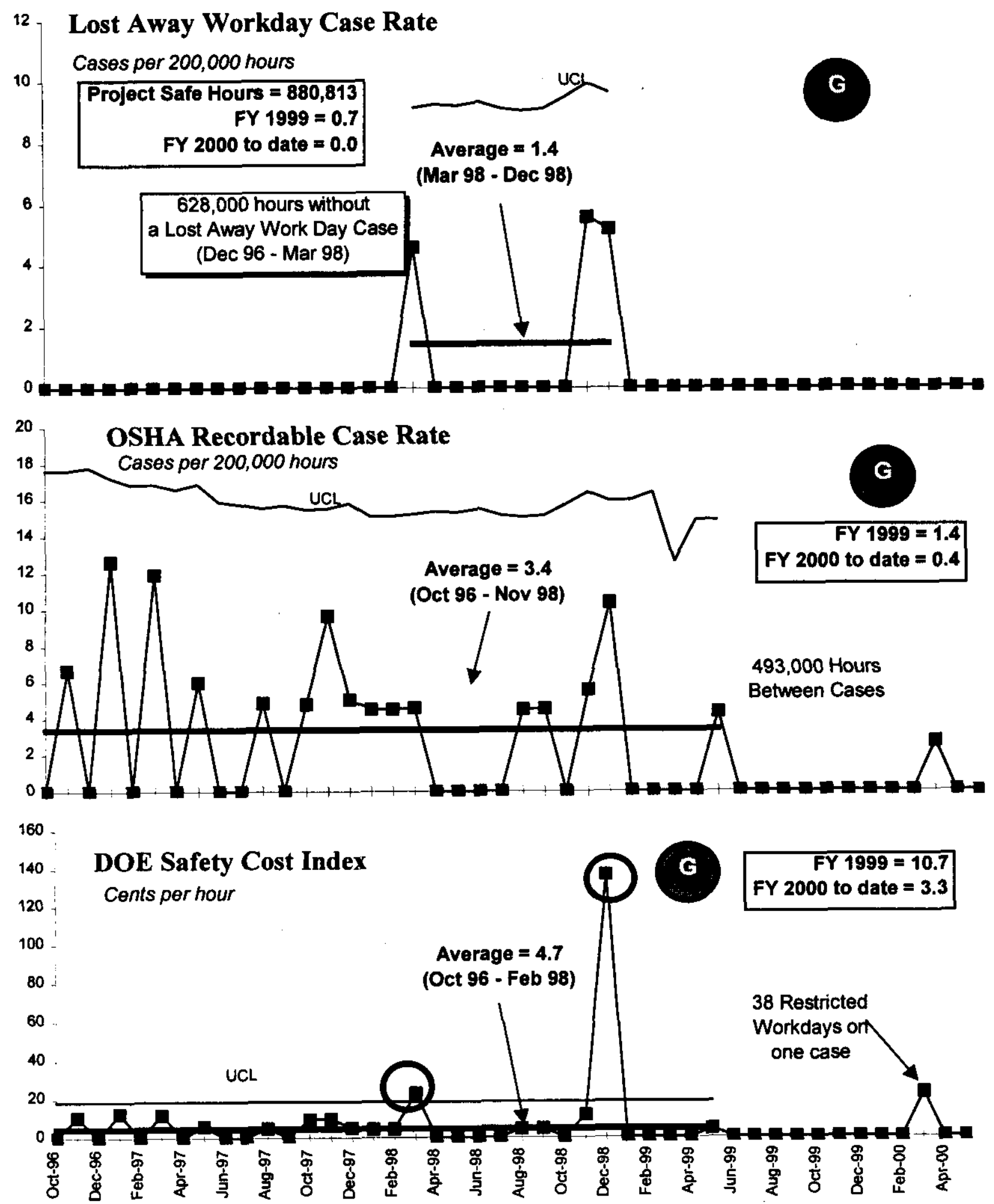


\section{CONDUCT OF OpERATIONS / ISMS STATUS CONDUCT OF OpERATIONS}

EVENTS PER 200,000 HOURS
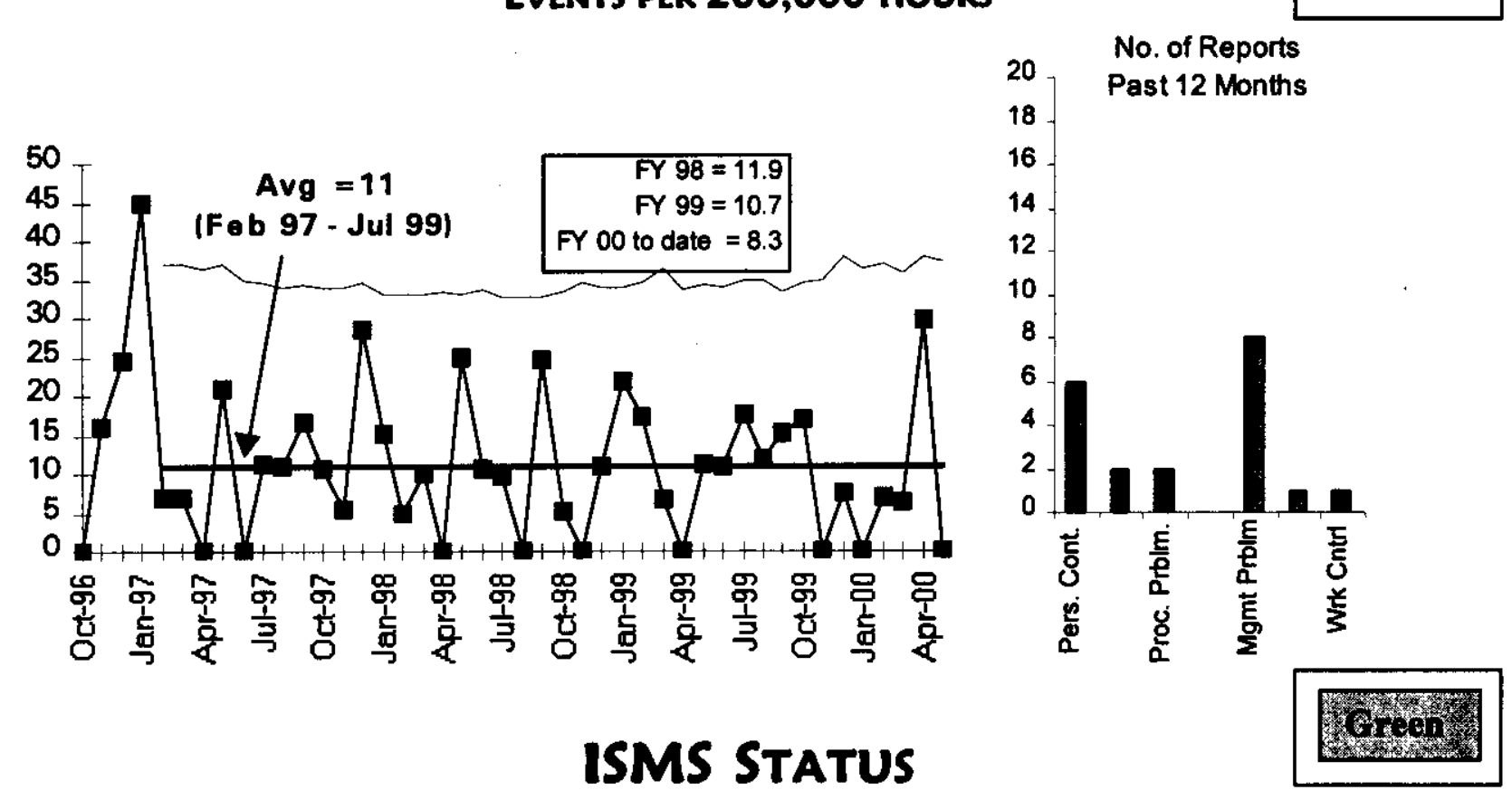

- ISMS Internal Readiness Review (IRR) completed; closure plan in progress

- $\quad$ Phase I Verification successfully completed April 28, 2000

- Declared Readiness for ISMS Phase II Verification May 2, 2000

- ISMS Phase II Verification scheduled for June 21-27, 2000

\section{BREAKTHROUGHS / OPPORTUNITIES FOR IMPROVEMENT}

\section{Breakthroughs}

- Savings Through Alternative Disposition Strategy - Final disposition of Unirridiated Uranium fuel elements to low-level waste burial grounds vs. packaging and transportation to Portsmouth, Ohio for interim storage will save in excess of $\$ 1 \mathrm{M}$ over the current Project Management Plan cost baseline.

\section{Opportunities for Improvement}

- 324 Project Planning / Execution: An emphasis on improved schedule management to ensure that critical path negative float is recovered to positive float continues. Critical path method analysis of baseline schedule has lead to several schedule sequence changes devised to improve baseline performance. As work progresses, the need to re-sequence will continue to be assessed. 
devised to improve baseline performance. As work progresses, the need to re-sequence will continue to be assessed.

- Accelerate 384 Powerhouse Demolition - Revise existing DynCorp request for proposal for 200 Area Powerhouse demolition to include 384 Powerhouse and make it first priority.

\section{UPCOMING ACTIVITIES}

- Integrated Environmental, Safety \& Health Management System (ISMS) Complete verification of Phase II readiness activities by June 2000 .

- 300 Area Accelerated Closure Project Plan - Prepare and issue the 300 Area Accelerated Closure Project Plan, schedule and estimate June 29, 2000.

- B Plant Transfer to ERC - Complete closeout activities by July 28, 2000.

- $\quad 300$ Area Waste Acid Treatment System (WATS) Resource Conservation and Recovery Act (RCRA) Closure Activities - The final report due to $R L$ has been delayed until September 2000 due to the review and comment cycle with Washington Department of Ecology (WDOE). A baseline change request has been submitted to delete the milestone, TRP-99-301, "Submit Final Report on WATS Closure Activities to $R L . "$

- TPA Milestone M-89-02 - Complete Removal of 324 Building Radiochemical Engineering Cell (REC) B Cell Mixed Waste (MW) and Equipment by November 2000.

Cost Performance (\$M):

\begin{tabular}{|l|c|c|c|}
\hline & BCWP & ACWP & VARIANCE \\
\hline River Corridor Project & $\$ 39.6$ & $\$ 37.0$ & $\$ 2.6$ \\
\hline
\end{tabular}

The $\$ 2.6$ million (7.0 percent) favorable cost variance is within the established threshold. Further information at the PBS level can be found in the following Cost Variance Analysis details.

\section{SChedule Performance (\$M):}

\begin{tabular}{|l|c|c|c|}
\hline & BCWP & BCWS & VARIANCE \\
\hline River Corridor Project & $\$ 39.6$ & $\$ 39.1$ & $\$ .5$ \\
\hline
\end{tabular}

The $\$ 0.5$ million (1.0 percent) favorable schedule variance is within the established threshold. Further information at the PBS level can be found in the following Schedule Variance Analysis details. 
Fy 2000 Cost/Schedule Performance - All Fund Types Cumulative to Date STATUS - $(\$ 000)$

\begin{aligned} & \multicolumn{1}{c}{ By PBS } \\ PBS TP01 & B-Plant \\ WBS 1.4.1 & \\ PBS TP04 & 300 Area/ Special Nuclear \\ WBS 1.4.4 & Materials \\ PBS TP12 & Transition Program \\ WBS 1.4.6 & Management \\ PBS TP10 & Accelerated Deactivation \\ WBS 1.4.8 & \\ PBS TP08 & 324/327 Facility Transition \\ WBS 1.4.10 & Hanford Surplus Facility \\ PBS TP14 & Program (300Area \\ WBS 1.4.11 & Revitalization) \\ & Total \end{aligned}

\begin{tabular}{|c|c|c|c|c|c|c|c|c|c|c|c|c|c|c|c|c|c|}
\hline \multicolumn{2}{|c|}{ BCWS } & \multicolumn{2}{|c|}{ BCWP } & \multicolumn{2}{|c|}{ ACWP } & \multicolumn{2}{|c|}{ sv } & \multirow{2}{*}{$\begin{array}{l}\% \\
0 \%\end{array}$} & \multicolumn{2}{|c|}{$\mathrm{CV}$} & \multirow{2}{*}{$\begin{array}{l}\% \\
0 \%\end{array}$} & \multicolumn{2}{|c|}{ PEM } & \multicolumn{2}{|c|}{ FYSF } & \multicolumn{2}{|c|}{ EAC } \\
\hline s & 340 & s & 340 & 5 & 489 & 5 & 0 & & s & (149) & & 5 & 350 & s & 321 & s & 521 \\
\hline s & 1,797 & s & 1,796 & 5 & 1,682 & s & (0) & $0 \%$ & s & 115 & $6 \%$ & s & 2,697 & s & 3,150 & s & 3,150 \\
\hline s & 11,292 & s & 11,254 & S & 9,657 & s & (37) & $0 \%$ & s & 1,597 & $14 \%$ & $\mathbf{s}$ & 16,792 & s & 14,477 & s & 14,477 \\
\hline s & 1,402 & 5 & 1,404 & s & 1,420 & s & 2 & $0 \%$ & s & (15) & $-1 \%$ & s & 2,107 & s & 3,359 & s & 3,359 \\
\hline$s$ & 22,427 & s & 22,820 & 5 & 22,226 & s & 393 & $2 \%$ & s & 594 & $3 \%$ & s & 35,513 & s & 34,846 & s & 34,966 \\
\hline 5 & 1,848 & $\$$ & 1,986 & S & 1,484 & 5 & 138 & $7 \%$ & s & 502 & $25 \%$ & s & 2,862 & s & 2,581 & s & 2,581 \\
\hline s & 39,105 & 5 & 39,601 & $s$ & 36,958 & s & 496 & $1 \%$ & & 2,643 & $7 \%$ & 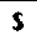 & 60,322 & 5 & 88,934 & S & 59,05 \\
\hline
\end{tabular}

Note: RL-Directed costs (steam and laundry) are included in the PEM BCWS. 310 TEDF/340 Facility performance data is reported under PBS WM05 (Waste Management).

\section{Cost/SChedule Performance Indices (MONTHLY AND FYTD)}

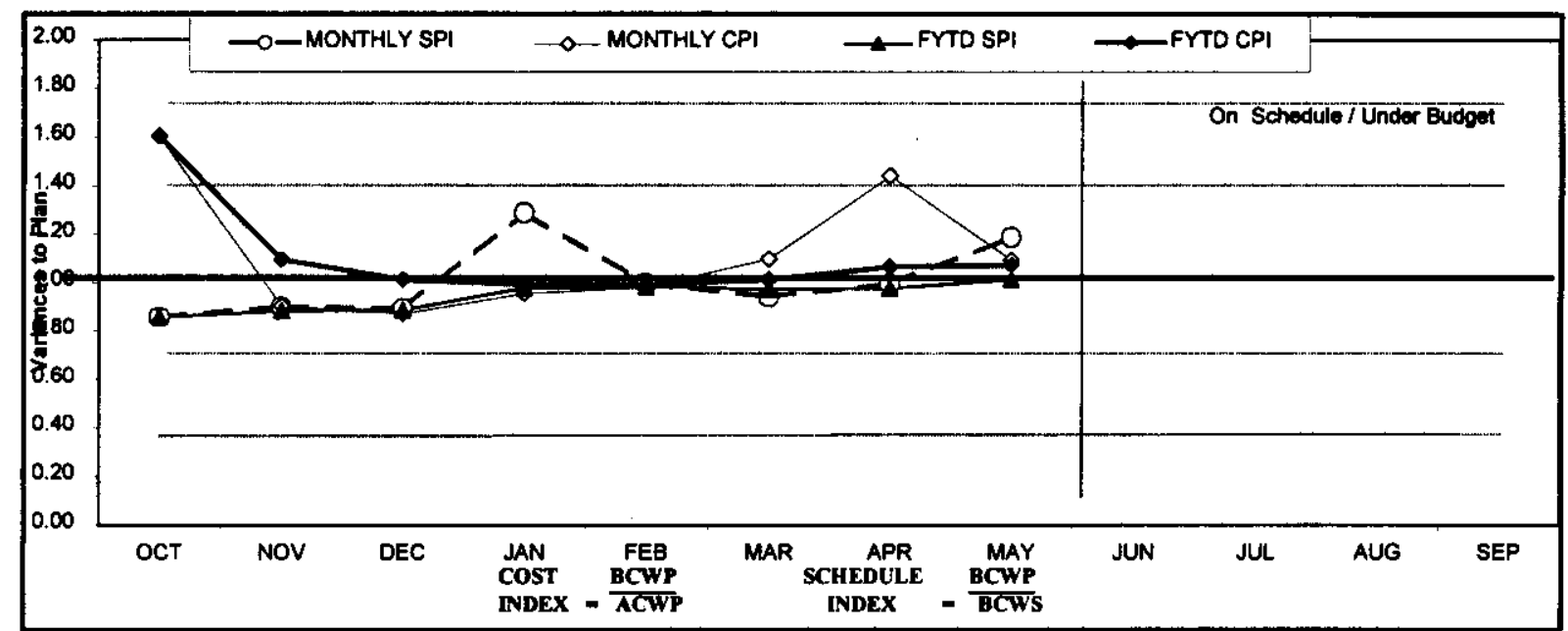

\begin{tabular}{|c|c|c|c|c|c|c|c|c|c|c|c|c|}
\hline FY2U00 & OCT & NOV & DEC & JXN & TES & MAR & APR & MAY & JUN & JUL & AU6 & SEP \\
\hline MONTHICYSP & 0.86 & 0.90 & 0,89 & 1.29 & 1.00 & 0.94 & 0.99 & 1.19 & & & & \\
\hline WONTILYCPI & 1.60 & $0 . \%$ & 0.87 & $0 . \%$ & 0.98 & 1.10 & 1.44 & 1.09 & & & & \\
\hline FYIDSPI & 0.86 & 0.88 & 0.89 & 0.98 & 0.98 & 0.97 & 0.98 & 7.01 & & & & \\
\hline FYIDCPI & 5.60 & I.To & 1.01 & 0.94 & 0.99 & 1.01 & 1.07 & 1.07 & & & & \\
\hline MONTHLYBCWS & 53,649 & 35,138 & 34,089 & 35,855 & 34,290 & 35,980 & 35,433 & 56,651 & 35,166 & 34,704 & 56,150 & 35,197 \\
\hline MONTHLYBCWP & 33,131 & 34,646 & $\$ 3,634$ & 3,973 & 5,270 & 35,635 & 35,398 & 37,894 & & & & \\
\hline MONTHIY ACWP & $\$ 1,954$ & 35,341 & 34,195 & 35,206 & 34,357 & 35,135 & 33,750 & 37,221 & & & & \\
\hline FYTDECWS & 35,649 & 38,807 & $312,8 \%$ & 316,751 & $\$ 21,041$ & 327,021 & 532,454 & 339,105 & 344,27I & 348,974 & 355,125 & 560,322 \\
\hline FYTD BCWP & 35,131 & $37,7 / 7$ & 311,431 & $\$ 16,404$ & 320,674 & 326,309 & 351,707 & $\$ 39,601$ & & & & \\
\hline FYTD ACWP & \$1,954 & $37,0,95$ & SII,290 & $316,4 \%$ & 520,853 & 325,988 & 329,738 & 336,958 & & & & \\
\hline
\end{tabular}




\section{COST VARIANCE ANALYSIS: $(+\$ 2.6 \mathrm{M})$}

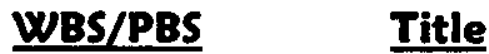

\subsection{1/TP01 B Plant}

Description and Cause: The unfavorable cost variance is the result of a partial implementation of approved BCR FSP-2000-008 in HANDI.

Impact: No impact.

Corrective Action: Implementation of BCR FSP-2000-008 will be completed in June.

\subsection{6/TP12 Transition Project Management}

Description and Cause: The favorable cost variance is primarily due to the Fluor Project Management Team re-structuring which has mapped personnel from the sub-project to other subprojects (i.e. Nuclear Material Stabilization), resulting in underruns in labor and contractor support.

Impact: No impact.

Corrective Action: Although this PBS reflects a substantial cost variance, the funding is less than the scope.

\subsubsection{1/TP14 HSFP 300 Area Revitalization}

Description and Cause: The favorable cost variance is primarily due to lower than planned costs in associated with Accelerated Closure Plan activities.

Impact: No impact.

Corrective Action: Any underruns in funding will be utilized to support super stretch activities and emerging work scope.

All other PBS variances are within established thresholds.

\section{SCHEDUle VARIANCE ANALYSIS: (\$0.5M)}

All PBS variances are within established thresholds.

\section{ISSUES}

\section{Technical Issues}

Nothing to report.

\section{DOE/Regulator/External Issues}

Issue: Approval by DOE-HQ of the Unirradiated Uranium (UU) billet Safety Analysis Report for Packaging (SARP), Revision K, is required by July 15, 2000. Performance Initiatives 
encourage the accelerated disposition of this material; however, review and approval time frames do not support attempts to accelerate shipments.

Impact: Failure to gain approval on or before July 15, 2000 will jeopardize the shipment schedule for the billets thus losing the opportunity to complete the billet transfer in FY 2000. Performance Incentive RC3-SS Uranium Disposition will be impacted by the inability to ship billets in FY 2000.

Corrective Action: DOE-RL is aware of the issue. DOE-HQ has initiated the review and approval process. Approval is expected by July 15, 2000.

\section{baseline Change Requests Currently in Process}

$(\$ 000)$

\begin{tabular}{|c|c|c|c|c|c|c|c|c|c|}
\hline $\begin{array}{l}\text { PROJECT } \\
\text { CHANGE } \\
\text { NUMBER }\end{array}$ & $\begin{array}{l}\text { DATE } \\
\text { ORIGIN. }\end{array}$ & BCR TITLE & $\begin{array}{l}\text { FYOO COST } \\
\text { IMPACT }\end{array}$ & $\mathrm{SCH}$ & TECH & $\begin{array}{l}\text { DATE } \\
\text { TO CCB }\end{array}$ & $\begin{array}{c}\text { CCB } \\
\text { APRVD }\end{array}$ & $\begin{array}{c}\mathbf{R L} \\
\text { APR'VD }\end{array}$ & $\begin{array}{l}\text { CURRENT } \\
\text { STATUS }\end{array}$ \\
\hline 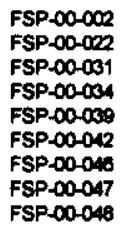 & $\begin{array}{l}11 / 2 / 00 \\
1 / 31 / 00 \\
3 / 22 / 00 \\
3 / 24 / 00 \\
421 / 00 \\
5 / 400 \\
5 / 24 / 00 \\
5 / 2400 \\
6 / 5100\end{array}$ & 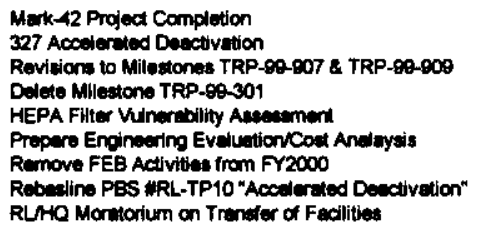 & $\begin{array}{l}\$ 0 \\
\$ 4,573 \\
\$ 0 \\
\$ 0 \\
50 \\
\$ 40 \\
\$ 277 \\
\$ 0 \\
\$ 0\end{array}$ & $\begin{array}{l}x \\
x\end{array}$ & $\begin{array}{l}x \\
x \\
x \\
x\end{array}$ & $\begin{array}{c}0405100 \\
0405100 \\
0405100 \\
0405100 \\
\text { N/A } \\
\text { NA }\end{array}$ & $\begin{array}{c}\text { ON107100 } \\
04 / 1300 \\
\text { ON/1300 } \\
\text { N/A } \\
\text { NA }\end{array}$ & $\begin{array}{l}\text { OS/18mo } \\
05 / 16 N 00 \\
\text { OS/16No0 } \\
\text { N/A } \\
\text { NA } \\
\text { N/A }\end{array}$ & 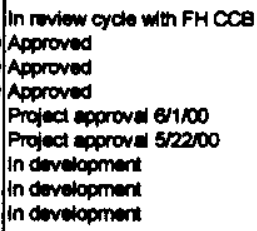 \\
\hline \multicolumn{10}{|c|}{ ADVANCE WORK AUTHOFIZATIONS } \\
\hline AWA & $8 / 1,00$ & 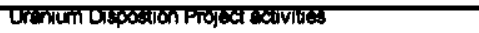 & $3 \times \$ 0$ & & $\mathrm{x}$ & $6 \% 3009$ & $6 \% 50$ & Oaju/hat & 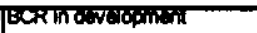 \\
\hline
\end{tabular}

\section{Milestone ACHIEVEMENT}

\begin{tabular}{|c|c|c|c|c|c|c|c|c|}
\hline \multirow[b]{2}{*}{ MILESTONE TYPE } & \multicolumn{4}{|c|}{ FISCAL YEAR-TO-DATE } & \multicolumn{3}{|c|}{ REMAINING SCHEDULED } & \multirow[b]{2}{*}{$\begin{array}{l}\text { TOTAL } \\
\text { FY } 2000\end{array}$} \\
\hline & $\begin{array}{l}\text { Completed } \\
\text { Early }\end{array}$ & $\begin{array}{l}\text { Completed } \\
\text { On } \\
\text { Schedule }\end{array}$ & $\begin{array}{c}\text { Completed } \\
\text { Late }\end{array}$ & Overdue & $\begin{array}{c}\text { Forecast } \\
\text { Early }\end{array}$ & $\begin{array}{c}\text { Forecast } \\
\text { On } \\
\text { Schedule }\end{array}$ & $\begin{array}{c}\text { Forecast } \\
\text { Late }\end{array}$ & \\
\hline Enforceable Agreement & 1 & 0 & 0 & 0 & of & 0 & 0 & \\
\hline ONFSB & 0 & 0 & 0 & 0 & of & 0 & 0 & \\
\hline DOE-HQ & 0 & 0 & 0 & 0 & of & 0 & of & \\
\hline $\mathbf{R L}$ & 2 & 1 & 0 & 7 & of & 0 & of & \\
\hline Total Project & 3 & 1 & 0 & $T$ & of & 0 & 0 & 5 \\
\hline
\end{tabular}




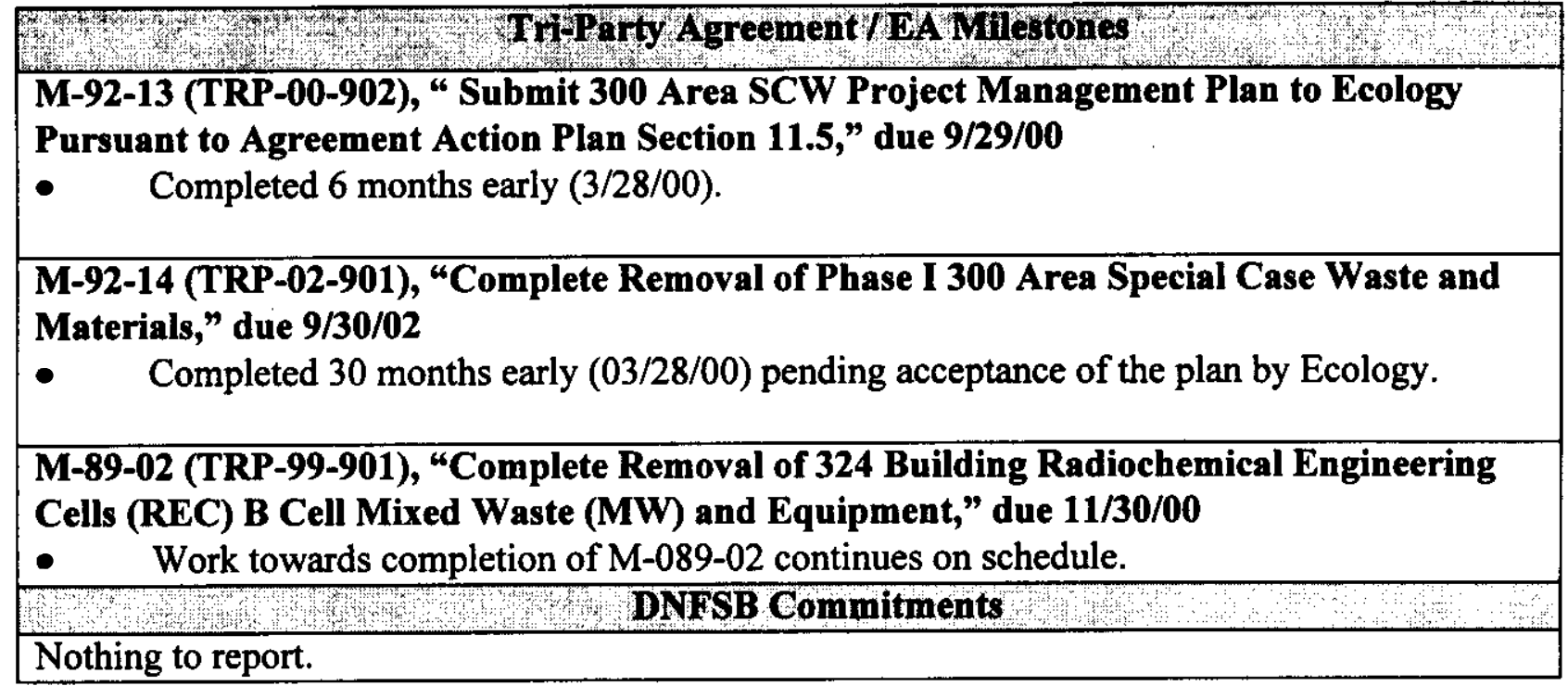

\section{MILESTONE EXCEPTION REPORT}

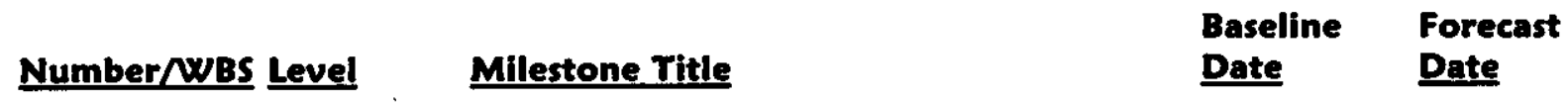

\section{OVerdue - 1}

TRP-99-933 RL Containerize Dispersible Under 2A Rack $\quad 04 / 30 / 00 \quad 07 / 06 / 00$

\subsubsection{0}

Cause: It has been determined it is more efficient to complete dispersible collection once size reduction of miscellaneous items is completed.

Impact: No impact.

Corrective Action: No corrective action is required.

\section{FORECAST LATE - 0}

\section{FY 1999 OVERDUE - 1}

$\begin{array}{llll}\text { TRP-99-800 RL } & \text { End Point Improvement Method } & 06 / 25 / 99 & \begin{array}{l}\text { To Be } \\ \text { Deleted }\end{array}\end{array}$

Cause: Resources necessary to complete this milestone were diverted to other priority work. This milestone represents an enhancement in Facility Stabilization Project's ability to plan deactivation work, but it is not essential.

Impact: No impact. This work scope is independent of the PMBS critical path and does not impact any schedule.

Corrective Action: Deletion of this milestone is included in the BCR which re-baselines TP-10 and is currently in development. 


\section{Performance Objectives}

\begin{tabular}{|c|c|c|}
\hline Outcome & Performance Indicator & Status \\
\hline \multirow{7}{*}{$\begin{array}{l}\text { Restore } \\
\text { the River } \\
\text { Corridor } \\
\text { for } \\
\text { Multiple } \\
\text { Uses }\end{array}$} & $\begin{array}{l}\text { FDH-RC-2 } \\
\text { Accelerate 324/327 } \\
\text { Deactivation. }\end{array}$ & $\begin{array}{l}\text { On track - no issues. Current Life Cycle Schedule Variance .4\% and Life } \\
\text { Cycle Cost Variance } .6 \% \text {. }\end{array}$ \\
\hline & $\begin{array}{l}\text { FDH-RC-2SS } \\
\text { Continue Acceleration of } \\
324 / 327 \text { Deactivation - } \\
\text { Complete } 327 \text { Facility } \\
\text { accelerated deactivation } \\
\text { activities by September } \\
2000 .\end{array}$ & $\begin{array}{l}\text { Issues related to revised Safety Analysis Report for Packaging may } \\
\text { jeopardize this PI. Alternatives have been evaluated, and a contingency } \\
\text { plan results in a } \$ 205 \mathrm{~K} \text { cost increase and a schedule delay of } 4-8 \text { weeks. }\end{array}$ \\
\hline & $\begin{array}{l}\text { FDH-RC-3SS } \\
\text { Disposition Uranium } \\
\text { Complete disposition of } \\
\text { 1865 Metric Tons (MT) } \\
\text { of Hanford Uranium by } \\
\text { September } 2000 .\end{array}$ & $\begin{array}{l}\text { At risk - FH has identified } \$ 295 \mathrm{~K} \text { for continuation of project activities. } \\
\text { There are minimal constraints to accomplish this work; however, funding is } \\
\text { an issue. An alternative strategy has been proposed to RL that supports } \\
\text { completion of the Uranium Disposition. }\end{array}$ \\
\hline & FDH-RC-5SS & On track - No issues. \\
\hline & $\begin{array}{l}\text { Accelerate } 300 \text { Area } \\
\text { Closure Project. }\end{array}$ & \\
\hline & FDH-RC-5SS-2 & $\begin{array}{l}\text { Unrecoverable - No funds identified to support completion of physical } \\
\text { work. Engineering Evaluation/Cost Estimate is in process. }\end{array}$ \\
\hline & $\begin{array}{l}\text { Accelerate Cleanup of } \\
\text { zone } 4 \text { of } 300 \text { Area. }\end{array}$ & \\
\hline Multiple & $\begin{array}{l}\text { Comprehensive } \\
\text { performance }\end{array}$ & All baseline work projected to be complete per PI requirements. \\
\hline
\end{tabular}




\section{KeY INTEGRATION ACTIVITIES}

- Complete National Facility Deactivation Initiative (NFDI) DOE-complex implementation plan.

- $\quad$ The RCP 324 Building B Cell project, along with Spent Nuclear Fuel (SNF), developed an alternative plan for the fuel removal activity. Agreement to use a longer inner canister for the fuel permits greater end shielding and allows manual welding and testing in the Cask Handling Area (CHA), rather than the more expensive, remote effort in B Cell. SNF and RL are reviewing the options study to determine cost savings against the 200 Area Interim Storage life cycle costs. Following the review, a memorandum of agreement will be issued documenting the interface between SNF and RCP.

- The DOE-HQ-funded study of High-Level Vault Tank 105, located in the 324 Building is being conducted by AEA Technologies to demonstrate new technology in the deactivation of high-dose radioactive tanks. The project technical plan, implementation plan, and the draft of the alternatives assessment are complete. Comments have been forwarded to AEA Technologies and have been incorporated into the assessment. The final report will be issued by June 23,2000. A mock-up demonstration of the selected technology is to be performed in August 2000.

- $\quad 300$ Area Accelerated Closure Plan team has been formed with Fluor Hanford, Bechtel Hanford, Inc. and Pacific Northwest National Laboratory participating. The planning effort is on schedule to support a June 29, 2000 transmittal date to RL.

- River Corridor Project (RCP) contributed to a Pacific Northwest National Laboratory (PNNL)-sponsored technical review on deactivation and decommissioning with two senior members from the WAK Facility located in Karlsruhe, Germany on June 8, 2000. As part of a Hanford site tour, RCP provided an overview presentation on the 324 Deactivation Project, followed by a facility tour. A presentation was also given in the deactivation progress and challenges at the Karlsruhe facility.

- In collaboration with Bechtel Hanford, Inc. (BHI), plans are being developed to demonstrate the use of a 3-D GAMMA camera in the 324 and/or 327 buildings in late June.

- $\quad$ RCP participated in a demonstration of wearable computers developed by a German based company called Xybernaut. The Xybernaut systems provide miniaturized, voiceactivated audio/visual for improving field productivity and safety. The systems allow for mobile access to databases of manuals, procedures, drawings, video training, and numerous other applications. 


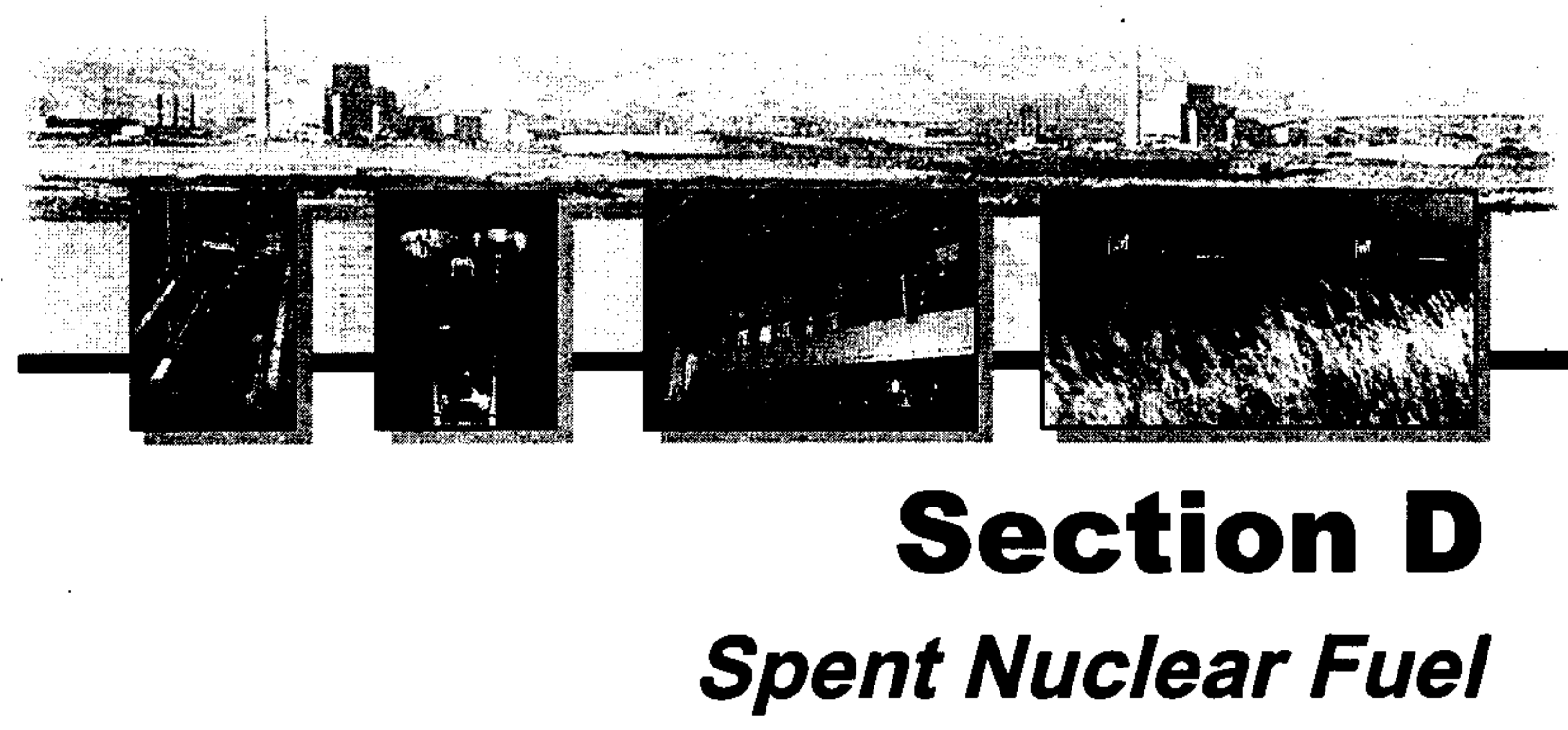

PROJECT MANAGERS

P.G. Loscoe, RL (509) 373-7465

R.G. Jones, $\mathrm{FH}$ (509) $376-1413$ 


\section{SUMMARY}

The Spent Nuclear Fuel (SNF) mission consists of the Spent Nuclear Fuel Project WBS 1.3.1.1 (Project Baseline Summary [PBS] WM01) and the subsequent Canister Storage Building (CSB) Operations Project WBS 1.3.2.1 (PBS WM02), which doesn't start until FY 2004.

NOTE: Unless otherwise noted, the Safety, Conduct of Operations, Milestone Achievement, and Cost/Schedule data contained herein is as of May 31, 2000. All other information is as of June $19,2000$.

The second shipment of six Multi-Canister Overpacks (MCOs) was received from Joseph Oat, Inc. ahead of schedule. An additional receipt of eight MCOs is expected to be delivered to the Hanford Site June 22, 2000, which would bring the total of MCOs received to 18. Fabrication of the MCO baskets continued at the Hanford Site.

Fiscal year-to-date milestone performance (EA, DOE-HQ, and RL) shows that three out of four milestones ( 75 percent) were completed on or ahead of schedule and one milestone was completed late.

The Milestone Achievement details, found following cost and schedule variance analysis, which provides further information on all milestone types.

\section{ACCOMPLISHMENTS}

- Since October 2, 1999 the Project has achieved 1,200,000 safe work hours without a lost time incident.

- An additional six MCOs were delivered to the Hanford Site ahead of schedule.

- $\quad$ Tri-Party Agreement (TPA) Milestone M-034-05-T01, Submit DOE Approved Report Debris to Ecology/EPA, was submitted on May 22, 2000 completing this Milestone ahead of schedule.

- $\quad$ TPA Change Request, M-34-00-01, Spent Nuclear Fuel Project - Sludge Acceleration Strategy, was approved by Ecology and the Environmental Protection Agency on May $23,2000$.

- $\quad 114$ of the 127 assessments needed for the Phase 3 Readiness Assessment have been completed. Of the 622 assessments needed for the Operational Readiness Review, 522 have been submitted to the responsible organizations.

- The first production run of 60 Mark 1A baskets was completed ahead of schedule. 
- $\quad$ Phase Startup Initiative (PSI) Phase I and II testing activities continued. Component tests of the Integrated Water Treatment System (IWTS) and the Fuel Retrieval System (FRS) were completed successfully.

\section{SAFETY}

The project has achieved over 1,200,000 safe work hours. The past eleven of twelve months for the DOE Cost Index and Severity Rate have been below average. Although the SNF Project experienced some safety performance degradations with the start of FY 2000, performance continues to improve. October 1999 had two Restricted Workday Cases, and one Lost Away Workday Case. This was a nearly significant increase (close to but not above the UCL) on the Occupational Safety and Health Act (OSHA) Recordable Case Rate.

The project's safety record is improving in both OSHA recordables and DOE Cost Index. Lostaway overall has had only one case in the past year. 

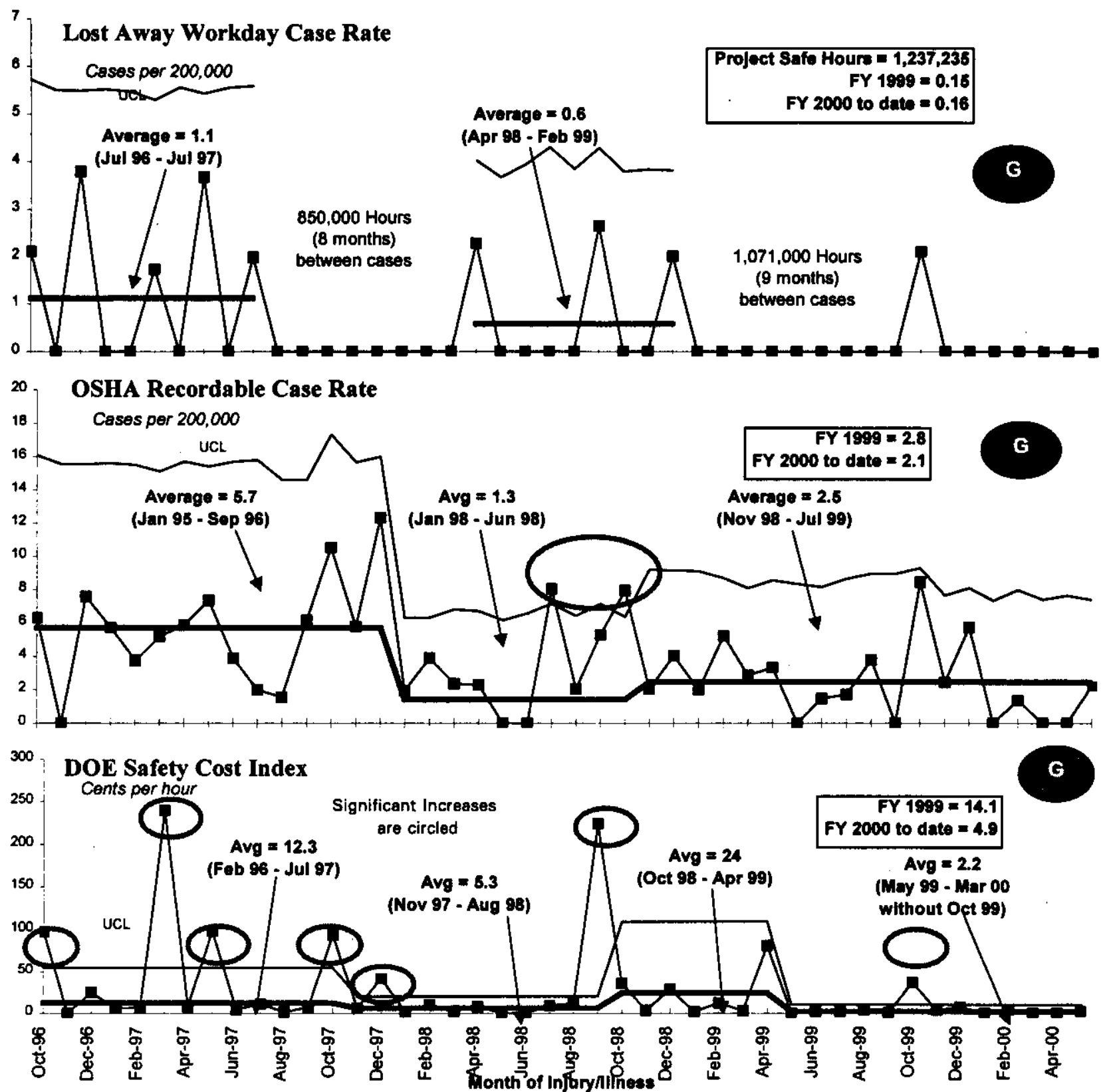


\section{CONDUCT OF OPERATIONS / ISMS STATUS CONDUCT OF OPERATIONS Events per 200,000 hours}

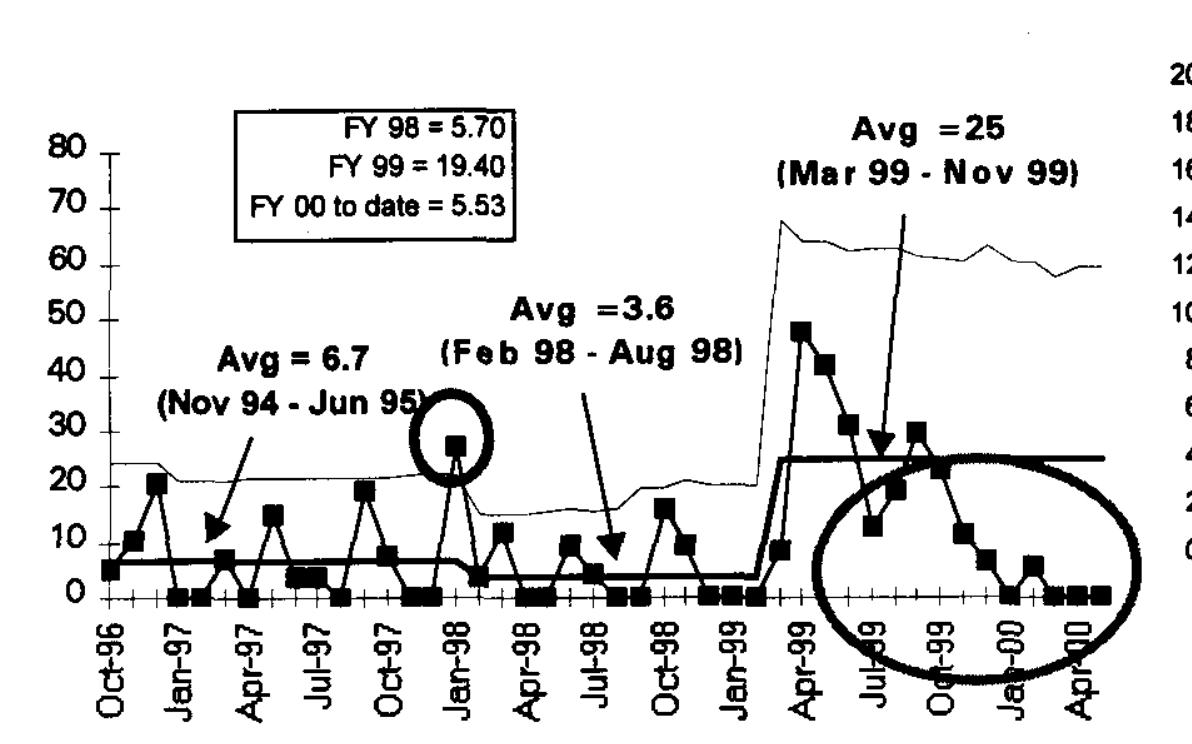

No. of Reports

Past 12 Months

\section{ISMS STATUS}

-

The ISMS Phase I/II verification for the SNF Project was completed on November 19, 1999.

- The Corrective Action Plans for the "Opportunities for Improvement" were developed and transmitted to RL on January 10, 2000.

- The actions required to enable ISMS implementation to be declared March 31, 2000 are now complete. Documentation packages have been transmitted to the Environmental, Safety \& Health organization. Three of the four packages were reviewed as part of the Project Hanford Management Contract (PHMC) Phase I verification. These items are complete. The remaining item needing $R L$ verification deals with Chemical Management Implementation and is scheduled to be verified by June 30, 2000.

\section{BREAKTHROUGHS / OPPORTUNITIES FOR IMPROVEMENT}

\section{Breakthroughs}

- $\quad$ Baseline Change Request SNF-2000-009, which accelerates the completion of sludge removal by one year from August 2005 to August 2004 and reduces total project life cycle cost by $\$ 16$ million, was implemented. 


\section{Opportunities for Improvement}

Phased Startup Initiative (PSI) - Results from the PSI are expected to improve the fuel production rates by approximately one month in FY 2001.

\section{UPCOMING ACTIVITIES}

Cold Vacuum Drying (CVD) Facility Testing - Testing at the CVD Facility continues to remain on the critical path. Completion of testing is scheduled for the end of July 2000.

Cask Loadout System (CLS) Testing — Complete startup testing by mid-July 2000.

Phased Startup Initiative (PSI) - Complete PSI Phases 1 and 2 in order to support start of Phase 3. Complete Phases 3 \& 4 by mid-August 2000.

Storage Projects - Delivery of eight more Multi-Canister Overpacks (MCO) is expected by the end of June.

Fuel Removal Activities - Begin DOE Operations Readiness Review by mid-September 2000. Begin K West Basin fuel removal, drying and storage operations by November 30, 2000.

\section{Cost Performance (\$M):}

\begin{tabular}{|l|c|c|c|}
\hline & BCWP & ACWP & VARIANCE \\
\hline Spent Nuclear Fuel & $\$ 139.8$ & $\$ 144.9$ & $-\$ 5.1$ \\
\hline
\end{tabular}

The unfavorable cost variance of $\$ 5.1$ million (4 percent) is primarily due to Hanford Site assessments higher than baseline and additional facility start up and engineering required as a result of first-of-a-kind equipment issues at $\mathrm{K}$ Basins and the CVD Facility.

\section{SChedule Performance ( $\$ M)$ :}

\begin{tabular}{|l|l|c|c|}
\hline & BCWP & BCWS & VARIANCE \\
\hline Spent Nuclear Fuel & $\$ 139.8$ & $\$ 139.7$ & $\$ 0.1$ \\
\hline
\end{tabular}

The favorable schedule variance of $\$ 0.1$ million ( 0 percent) is within the established thresholds. 


\section{FY 2000 COSt/SChedule Performance - All Fund Types Cumulative to Date Status - $\mathbf{( \$ 0 0 0 )}$}

FYTD

\begin{tabular}{|c|c|c|c|c|c|c|c|c|c|c|c|c|c|c|c|c|c|}
\hline \multicolumn{2}{|c|}{ By Pas } & \multicolumn{2}{|c|}{ BCWs } & \multicolumn{2}{|c|}{ BCWP } & \multicolumn{2}{|c|}{ ACWP } & \multicolumn{2}{|c|}{ sv } & $\%$ & cV & $\%$ & PEM & \multicolumn{2}{|r|}{ FYSF } & \multicolumn{2}{|r|}{ EAC } \\
\hline $\begin{array}{l}\text { BS WMO1 } \\
\text { WBS } 1.3\end{array}$ & $\begin{array}{l}\text { Spent Nuclear } \\
\text { Fuel Project }\end{array}$ & $s$ & 139,694 & s & 139,783 & s & 144,913 & $s$ & 89 & $\infty \% \$$ & $(5,131)$ & $-4 \%$ & 197,222 & $s$ & 201,257 & s & 201,257 \\
\hline & Total & $\mathbf{s}$ & 139,694 & s & 139,783 & s & 144,913 & $\mathbf{S}$ & 89 & $0 \% \$$ & $(5,131)$ & $-4 \%$ & 197,222 & $s$ & 201,257 & 5 & 201,257 \\
\hline
\end{tabular}

\section{Cost/SChedule Performance Indices (MONTHLY AND FYTD)}

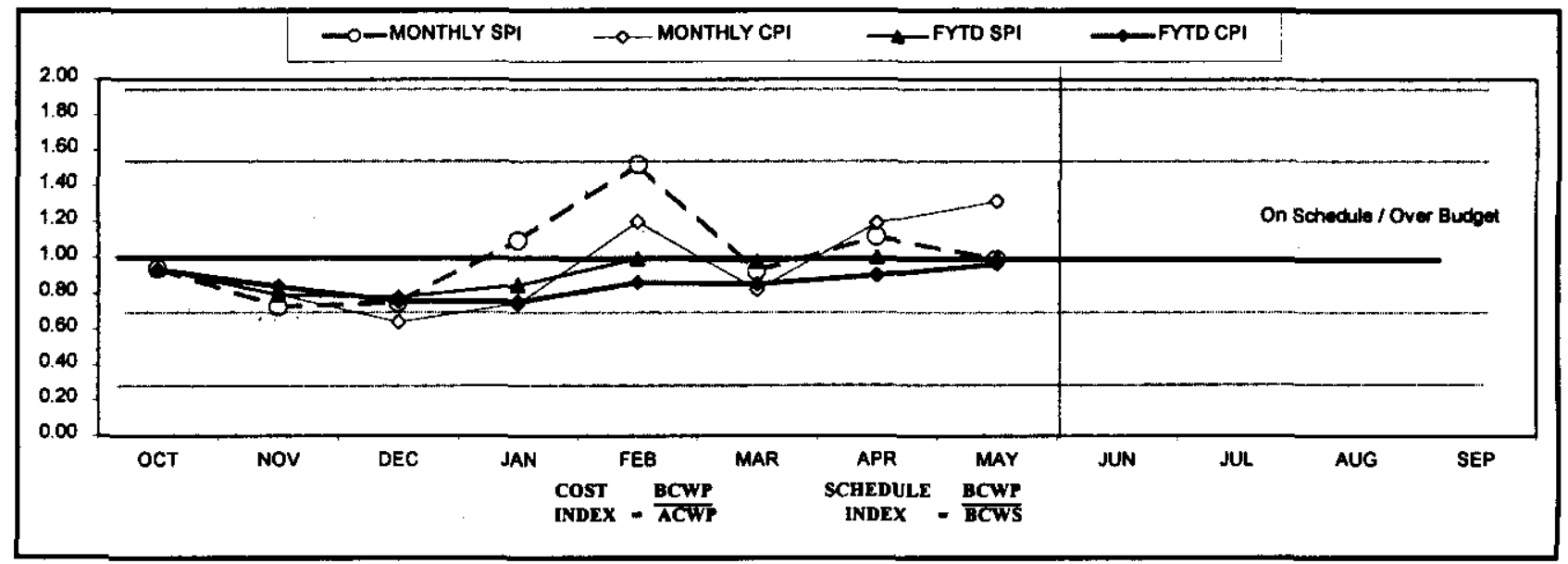

\begin{tabular}{|c|c|c|c|c|c|c|c|c|c|c|c|c|}
\hline FY2010 & OCT & NOV & $\mathbf{D X C}$ & JAN & FU: & MAK & APR & MRY & JUN & JUL & AvE & SEP \\
\hline MONIFICYSYI & 0.94 & 0.73 & 0.75 & 1.09 & 1.52 & 0.92 & 1.12 & 0.99 & & & & \\
\hline MONIRLYCPI & 0.93 & 0.79 & 0.64 & 0.74 & 1.20 & 0.82 & 1.19 & 1.31 & & & & \\
\hline FYTDSPI & 0.94 & 0.79 & 0.78 & 0.85 & 0.99 & 0.98 & T.00 & 1.00 & & & & \\
\hline FYTDCPI & 0.93 & 0.84 & 0.76 & 0.75 & 0.86 & 0.85 & 0.90 & 0.96 & & & & \\
\hline MONIFILY lycWS & 38,574 & 310,205 & 315,68T & 312,081 & 315,753 & 520,085 & 319,582 & 328,73 & 314,268 & $3 \longdiv { 2 , 2 7 6 }$ & 315,776 & 315,206 \\
\hline MONIFLY BSCWP & 38,049 & 313,968 & 311,776 & 313,221 & 325,909 & उ18,5ा1 & 321,838 & 328,517 & & & & \\
\hline MONTHLY ACWP & 38,626 & 317,581 & 318,370 & 317,831 & $\$ 19,906$ & $322,6 \pi$ & 318,286 & 321,703 & & & & \\
\hline FYTDECWS & 58,574 & 327,783 & 343,463 & 335,544 & 377,297 & 391,382 & 5110,963 & 3139.694 & $3153, \% 62$ & 3168,240 & $\$ 182,016$ & 3197,222 \\
\hline FYTDECWP & 38,049 & 522,016 & $\$ 33,786$ & 347,008 & 370,917 & 389,428 & 311,263 & 3139,783 & & & & \\
\hline FYTD ACWF & 58,626 & 326,207 & 34,577 & 362,408 & 382,314 & 3104,925 & 5123,210 & 5144,913 & & & & \\
\hline
\end{tabular}

\section{COST VARIANCE ANALYSIS: ( $\$ 5.1 \mathrm{M})$}

\section{WBS/PBS}

1.3.1/WM01

Description/Cause: The unfavorable cost variance of $\$ 5.1$ million (4 percent) is primarily due to Hanford Site assessments higher than baseline and additional facility start up and engineering required as a result of first-of-a-kind equipment issues at K Basins and the CVD Facility. Impact: The unanticipated site cost impacts, i.e., Corrective Action Management, Hanford Security, and fee allocation, are being compensated with appropriate site actions. In addition, Baseline Change Requests (BCRs) have been developed and reviewed and are on hold pending 
source availability for engineering, testing and administrative support. An \$8 million fiscal year end expense funding shortfall has been identified to $\mathrm{FH}$ and $\mathrm{RL}$ budget staff.

Corrective Action: Approve pending BCRs.

\section{SCHEDUle VARIance ANAlysis: (\$0.1M)}

\section{$\underline{\text { WBS/PBS }}$}

\subsection{1/ WMO1}

Description /Ca

established thresholds.

Impact: None.

Corrective Action: None

\section{Title}

Spent Nuclear Fuel Project

vorable schedule variance of $\$ 0.1 \mathrm{M}(0$ percent $)$ is within the

\section{ISSUES}

There are no technical, DOE, Regulator or external issues identified at this time. However, internal DOE budget reprogramming may be required to remedy SNF's projected FY 2000 expense funding shortage.

\section{Baseline Change Requests Currently in Process}

$(\$ 000)$

\begin{tabular}{|c|c|c|c|c|c|c|c|c|c|}
\hline $\begin{array}{l}\text { PROJECT } \\
\text { CHANGE } \\
\text { NUNBER }\end{array}$ & $\begin{array}{l}\text { DATE } \\
\text { ORIGIN. }\end{array}$ & BCR TITLE & $\begin{array}{l}\text { FYOO COST } \\
\text { IMPACT } \$ 000\end{array}$ & SCH & TECH & $\begin{array}{l}\text { DATE } \\
\text { TO CCB }\end{array}$ & $\begin{array}{c}\text { CCB } \\
\text { APRVO }\end{array}$ & $\stackrel{\mathbf{R L}}{\mathbf{A P R} \mathbf{R}^{\mathbf{V}}}$ & $\begin{array}{l}\text { CURRENT } \\
\text { STATUS }\end{array}$ \\
\hline SNF-2000-001 & $6 / 13 / 00$ & CAM/DTS Cost Alocation & $\$ 1,311$ & $\mathbf{N}$ & $\mathbf{Y}$ & & & & In preparation. \\
\hline SNF-2000-010 & $1 / 31 / 00$ & $\begin{array}{l}\text { SNF Project FY2000 MYWP } \\
\text { Revised Rate Impacts }\end{array}$ & $\$ 2,147$ & $\mathbf{N}$ & $\mathbf{N}$ & $5 / 15 / 00$ & $5 / 15 / 00$ & $6 / 5 / 00$ & $\begin{array}{l}\text { RL CO approved } \\
6 / 5 / 00 .\end{array}$ \\
\hline SNF-2000-014 & $3 / 20 / 00$ & $\begin{array}{l}\text { FY2000 Budget Authority } \\
\text { Increase }\end{array}$ & $\$ 1,300$ & $\mathbf{N}$ & $\mathbf{N}$ & $3 / 28 / 00$ & $4 / 27 / 00$ & $5 / 19 / 00$ & $\begin{array}{l}\text { RL CO approved } \\
5 / 19 / 00 .\end{array}$ \\
\hline SNF-2000-016 & $3 / 24 / 00$ & $\begin{array}{l}\text { Defer Site-Wide SNF Project } \\
\text { Activities to Align with Site- } \\
\text { Wide Prioritization }\end{array}$ & $(\$ 1,300)$ & $\mathbf{Y}$ & $\mathbf{Y}$ & $4 / 27 / 00$ & $4 / 27 / 00$ & $5 / 29 / 00$ & $\begin{array}{l}\text { RL CO approved } \\
5 / 29 / 00 .\end{array}$ \\
\hline SNF-2000-019 & $5 / 9 / 00$ & $\begin{array}{l}\text { Initiative Adding Phased III and } \\
\text { IV to Baseline }\end{array}$ & $\$ 2,500$ & $\mathbf{Y}$ & $\mathbf{Y}$ & & & & In preparation. \\
\hline & & & irt- & HO & ZAT & DNS & & & \\
\hline & & Nothing to report & & & & & & & \\
\hline
\end{tabular}




\section{SPENT NUCLEAR FUELS - WBS 1.3 \\ MILESTONE ACHIEVEMENT}

\begin{tabular}{|c|c|c|c|c|c|c|c|c|}
\hline \multirow[b]{2}{*}{ MILESTONE TYPE } & \multicolumn{4}{|c|}{ FISCAL YEAR-TO-DATE } & \multicolumn{3}{|c|}{ REMAINING SCHEDULED } & \multirow[b]{2}{*}{$\begin{array}{c}\text { TOTAL } \\
\text { FY } \\
2000\end{array}$} \\
\hline & $\begin{array}{c}\text { Completed } \\
\text { Early }\end{array}$ & $\begin{array}{c}\text { Completed } \\
\text { On } \\
\text { Schedule }\end{array}$ & $\begin{array}{c}\text { Completed } \\
\text { Late }\end{array}$ & Overdue & $\begin{array}{c}\text { Forecast } \\
\text { Early }\end{array}$ & $\begin{array}{c}\text { Forecast } \\
\text { On } \\
\text { Schedule }\end{array}$ & $\begin{array}{c}\text { Forecast } \\
\text { Late }\end{array}$ & \\
\hline Enforceable Agreement & 2 & 0 & $\overline{0}$ & 0 & 0 & $\overline{0}$ & 0 & 2 \\
\hline DOE-HQ & 0 & $\overline{0}$ & 0 & $\overline{0}$ & 0 & $\overline{0}$ & 0 & $\overline{0}$ \\
\hline $\mathrm{RL}$ & 1 & 0 & 1 & 0 & 0 & 1 & 0 & 3 \\
\hline Total Project & 3 & 0 & 1 & 0 & 0 & 1 & 0 & 5 \\
\hline
\end{tabular}

Status as of $6 / 19 / 2000$

Tri-Party Agreement / EA Milestones

\begin{tabular}{|l|l|l|}
\hline \multicolumn{1}{|c|}{ Number } & \multicolumn{1}{|c|}{ Milestone Title } & \multicolumn{1}{c|}{ Status } \\
\hline $\begin{array}{l}\text { M-34-14A } \\
\text { (S06-97-009) }\end{array}$ & $\begin{array}{l}\text { "Complete K West Basin Cask } \\
\text { Facility Modules" }\end{array}$ & $\begin{array}{l}\text { Due 2/29/00 - Completed on } \\
\text { schedule. }\end{array}$ \\
\hline $\begin{array}{l}\text { M-34-04 (S01- } \\
\text { 99-124) }\end{array}$ & $\begin{array}{l}\text { "Submit Remedial Design } \\
\text { Report/Remedial Action Work } \\
\text { Plan for the K Basins" }\end{array}$ & $\begin{array}{l}\text { Due 3/31/00 - Completed over 1 } \\
\text { month early (2/10/00). }\end{array}$ \\
\hline $\begin{array}{l}\text { M-34-05 (T01) } \\
\text { "Submit Report on Quantities, } \\
\text { Character, and Management of K } \\
\text { Basins Debris" }\end{array}$ & $\begin{array}{l}\text { Due 5/31/00 - Completed on } \\
\text { Schedule. }\end{array}$ \\
\hline $\begin{array}{l}\text { M-34-16 (S00- } \\
\text { 01-900) }\end{array}$ & $\begin{array}{l}\text { "Initiate removal of K West } \\
\text { Basin Spent Nuclear Fuel" }\end{array}$ & Due 11/30/00 - On schedule. \\
\hline $\begin{array}{l}\text { M-34-06-T01 } \\
\text { "Initiate K West Basin Spent } \\
\text { Nuclear Fuel Canister Cleaning } \\
\text { Operations" }\end{array}$ & Due 12/31/00 - On schedule. \\
\hline
\end{tabular}

\section{DNFSB Commitments}

\begin{tabular}{|l|l|l|}
\hline & Nothing to report. & \\
\hline & & \\
\hline
\end{tabular}

\section{MILESTONE EXCEPTION REPORT}

Nothing to report. 


\section{Performance Objectives}

Readiness for Fuel Movement (RC-1-1.a-I) - Contractor completion of construction and operational testing, Management Self-Assessment (MSA), and Independent Operational Readiness Review (ORR) by September 14, 2000 to begin moving fuel by November 30,2000. Start of fuel movement is currently on track for November 30, 2000.

Phased Startup Initiative (PSI) (RC-1-1.a-II) - Complete PSI Phases 1 and 2 by April 15, 2000. This includes successful Cold Testing of Integrated Water Treatment System (IWTS) \& Fuel Retrieval System (FRS). This activity is behind schedule due to required changes to the IWTS Control System Software. This accelerated non-critical path testing activity continues to allow KW Basin system problems to be uncovered and fixed much earlier that the baseline schedule.

Accelerate Fuel Movement (RC-1SS-1) - Accelerate start of fuel movement by two months. Pre-positioning of fuel processed in PSI Phase III will allow early loading of Multicanister Overpacks (MCOs). Assumes no problems during first fuel movement and no ORR or MSA discrepancies.

Phased Startup Initiative (PSI) (RC-1SS-2) — Complete Phases $3 \& 4$ by August 15, 2000. This includes completion of FRS/IWTS system testing using SNF (real fuel) and Completion of Construction Documentation Phase II

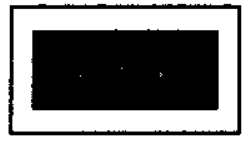
(CCD2). PSI Phases III \& IV are currently being restructured to reflect the delay caused by the IWTS Control System software failure.

\section{KEY INTEGRATION ACTIVITIES}

- $\quad$ Spent nuclear fuel (SNF) final disposition interface activities, including Office of Civilian Radiation Waste Management (OCRWM) Quality Assurance (QA) Program implementation, ongoing with National SNF Program.

- $\quad$ K Basins sludge removal and Shippingport (PA) Pressurized Water Reactor Core 2 SNF removal implementation activities ongoing with Waste Management Project.

- $\quad 324$ Building (B Cell) SNF removal acceptance criteria and conceptual design reviews ongoing with River Corridor Project.

- $\quad$ Neutron Radiography Facility, Training, Research and Isotope Production, General Atomics (TRIGA), and Fast Flux Test Facility (FFTF) SNF relocation planning ongoing with FFTF Project.

- Input provided to Bechtel Hanford, Incorporated (BHI) on recovery actions required if SNF is discovered during upcoming reactor basins deactivation.

- Completed assessment and documentation for the Canister Storage Building's readiness to support the receipt of Immobilized High Level Waste (IHLW) from Occurrence Reporting Program (ORP). 


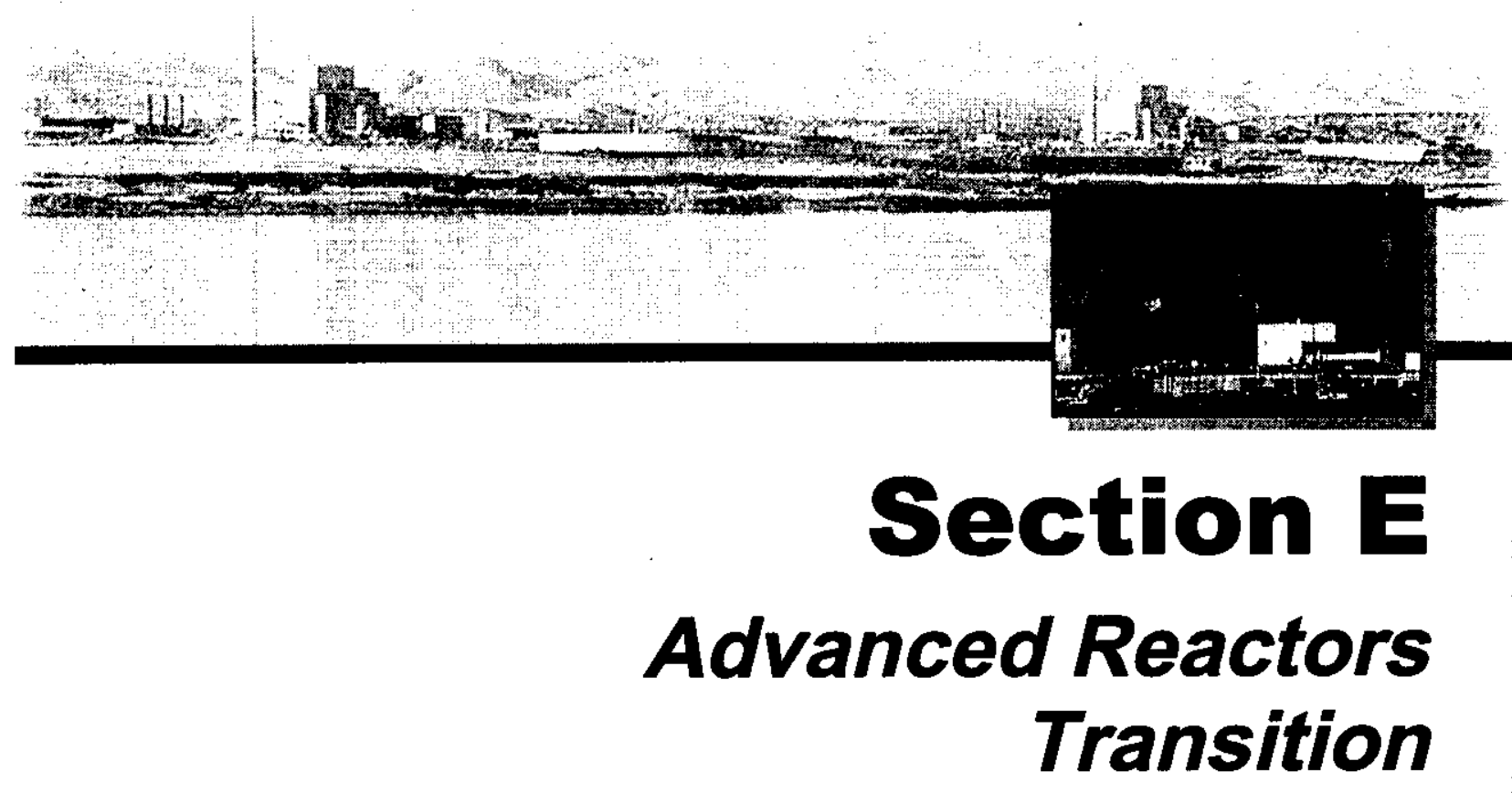

PROJECT MANAGERS

O.A. Farabee, RL (509) 376-8089

D.B. Klos, FH (509) 373-3574 


\section{SUMMARY}

The Advanced Reactors Transition (ART) Program, WBS 1.12.1.1, PBS RL-TP11, consists of the 309 Building and the Nuclear Energy (NE) Legacies activities.

NOTE: Unless otherwise noted, Cost/Schedule data contained herein is as of May 31, 2000. All other information is as of June 16,2000 , unless otherwise noted.

In May the ART mission area technical accomplishments included continued surveillance and maintenance activities on the 309 Building and NE Legacy facilities. Several hundred gallons of high $\mathrm{pH}$ solution produced during the T-Plant tank sodium residue removal operation were trucked to the Treated Effluent Disposal Facility. This action closes out the T-Plant tank residue removal operation. One of the clean tanks will be used in the $\mathrm{NaK}$ loop residue removal task and the other is available for scrap or recycle. Shop and field fabrication is underway for the piping and components required for the cleanup of the $\mathrm{NaK}$ residues in the cold trap cooling system in the 337 Building. These will be connected to the NaK system for draining the small amount of remaining bulk $\mathrm{NaK}$ and then reacting the remaining residue with water vapor-nitrogen. In the 309 Building, deactivation activities included asbestos removal in the lower levels of the containment facility.

Fiscal-year-to-date milestone performance (EA, DOE-HQ, and RL) shows that there are no milestones due.

\section{ACCOMPLISHMENTS}

- $\quad$ Continued surveillance and maintenance activities on 309 Building and NE legacies.

- $\quad$ Closed out the sodium residue removal operation for the T-Plant tank.

- $\quad$ Continued shop and field fabrication for the piping and components required for the cleanup of the $\mathrm{NaK}$ residue in the cold trap cooling system in the 337 Building.

- Continued the 309 Building deactivation progress with cleaning of asbestos in the lower levels of the containment facility.

\section{SAFETY}

Safety data for ART is included in a separate FFTF report. 


\section{CONDUCT OF OPERATIONS / ISMS STATUS CONDUCT OF OPERATIONS}

Conduct of operations data for ART is included in a separate Fast Flux Test Facility (FFTF) report.

\section{ISMS STATUS}

Preparations continued for the ISMS Readiness Assessment Phase II that started on June 26, 2000.

\section{BREAKTHROUGHS / OPPORTUNITIES FOR IMPROVEMENT}

No breakthroughs or opportunities for improvement have been identified at this time.

\section{UPCOMING ACTIVITIES}

- $\quad$ Proceed with cleaning of the sodium potassium $(\mathrm{NaK})$ residuals from the 337B Building cold trap cooling loop.

- Initiate Fuel Transfer Pit cleanout in the 309 Building/PRTR facility.

\section{Cost Performance $(\$ M):$}

\begin{tabular}{|l|c|c|c|}
\hline & BCWP & ACWP & VARIANCE \\
\hline Advanced Reactors Transition & $\$ 1.0$ & $\$ 0.9$ & $+\$ 0.1$ \\
\hline
\end{tabular}

The favorable $\$ 0.1 \mathrm{M}$ (10 percent) cost variance is due to no significant corrective maintenance activities required.

\section{Schedule Performance (\$M):}

\begin{tabular}{|l|c|c|c|}
\hline & BCWP & BCWS & VARIANCE \\
\hline Advanced Reactors Transition & $\$ 1.0$ & $\$ 1.0$ & $\$ 0.0$ \\
\hline
\end{tabular}

The 3 percent schedule variance is insignificant. 


\section{Fy 2000 COSt/SChedule PerformanCe - All Fund Types Cumulative to Date Status - (\$000)}

FYTD

By PBS

PBS TP11 Advanced Reactors

WBS 1.12 Transition

Total

BCWS BCWP ACWP SV $\%$ CV $\%$ PEM FYSF EAC

$\begin{array}{llllllllllll}\text { \$ } 997 & \$ 972 & \$ 875 & \$(24) & -2 \% & \$ 98 & 10 \% & \$ 1,673 & \$ 1,105 & \$ 1,318\end{array}$

$\begin{array}{llllllllllllll}\text { \$ } 997 & \$ 972 & \$ 875 & \$(24) & -2 \% & \$ 98 & 10 \% & \$ 1,673 & \$ 1,105 & \$ 1,318\end{array}$

\section{Cost/Schedule Performance Indices (MONTHLY AND FYTD)}

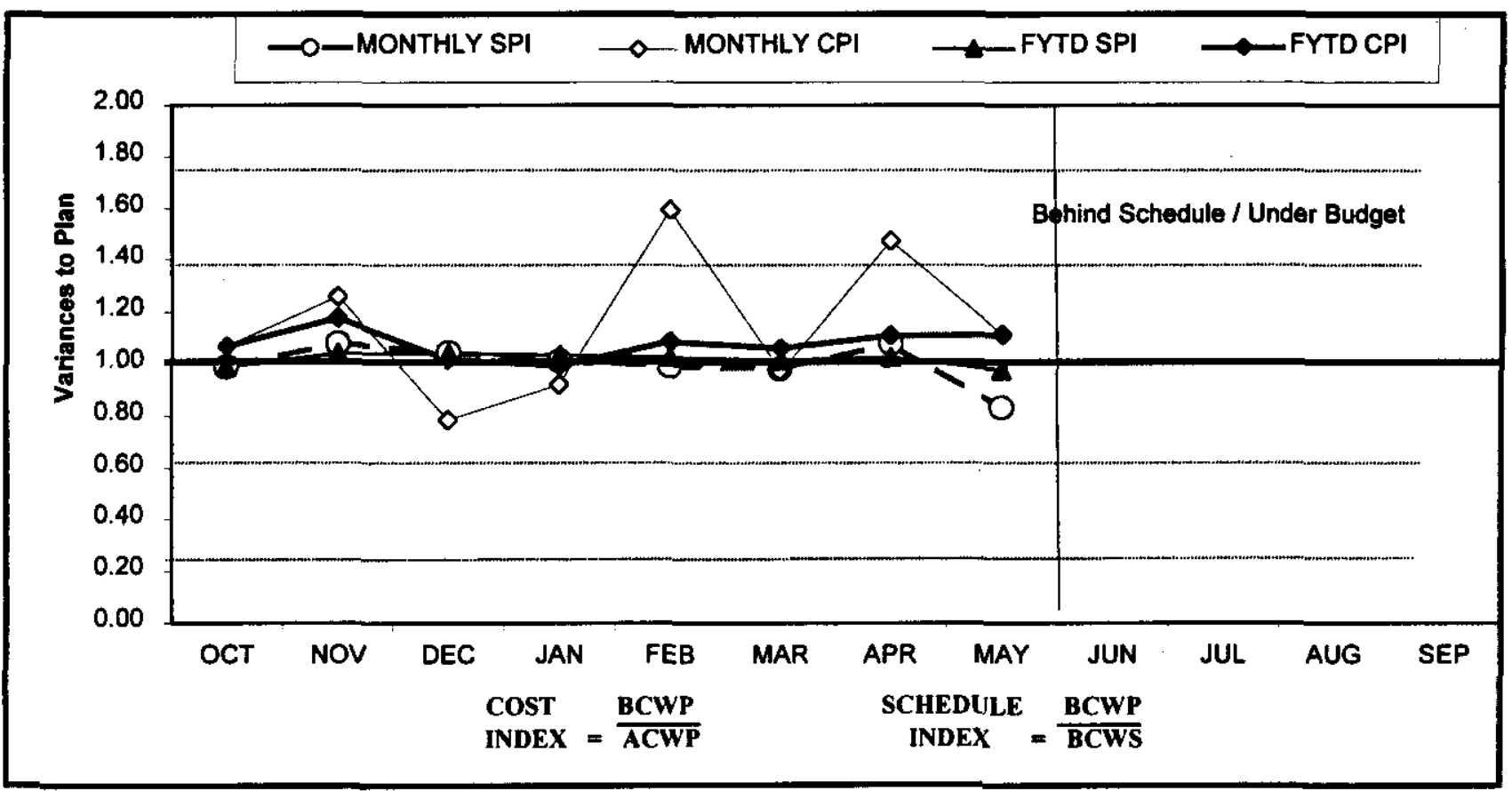

\begin{tabular}{|c|c|c|c|c|c|c|c|c|c|c|c|c|}
\hline FY 2000 & OCT & Nov & DEC & JAN & FEB & MAR & APR & MAY & JUN & JUL & AUG & SEP \\
\hline MONTHLY SPI & 0.99 & 1.08 & 1.03 & 1.01 & 0.99 & 0.98 & 1.08 & 0.83 & & & & \\
\hline MONTHLYCPT & 1.07 & 1.26 & 0.79 & 0.92 & T.59 & 0.97 & T.47 & $T .12$ & & & & \\
\hline FYTISSPI & 0.99 & 1.04 & 1.04 & T.03 & 1.02 & T.01 & 1.02 & 0.98 & & & & \\
\hline FYTDCPI & 1.07 & 1.18 & 1.02 & 0.99 & 1.09 & 1.06 & T.II & $\Pi \Pi$ & & & & \\
\hline MONTHLYBCWS & $\$ 79$ & डा13 & $\mathbf{5 8 8}$ & $\$ 93$ & $\$ 116$ & $\$ 139$ & 5116 & 3254 & $\$ 146$ & $\$ 144$ & 3196 & 3191 \\
\hline MONTHLY BCWP & $\$ 78$ & \$122 & $\$ 92$ & 394 & डा15 & S136 & $\$ 125$ & \$2TI & & & & \\
\hline MONTHLYACWP & $\$ 73$ & 397 & \$ा7 & $\$ 102$ & $\$ 72$ & $\$ 140$ & 385 & \$189 & & & & \\
\hline FYTIJBCWS & $\$ 79$ & $\mathbf{3 1 9 2}$ & $\$ 280$ & $\$ 373$ & 3489 & 5627 & $\$ 743$ & $\$ 997$ & $\$ 1,143$ & $\$ 1,286$ & $\$ 1,483$ & 31,673 \\
\hline FYTDBCWP & 578 & $\$ 200$ & $\$ 292$ & $\$ 386$ & $\$ 501$ & $\$ 637$ & $\$ 761$ & $\$ 972$ & & & & \\
\hline FYTI ACWP & $\$ 73$ & $\$ 170$ & $\$ 287$ & $\$ 389$ & उ46ा & $\$ 601$ & $\$ 686$ & $\$ 875$ & & & & \\
\hline
\end{tabular}




\section{COST VARIANCE ANALYSIS: $(+\$ 0.1 \mathrm{M})$}

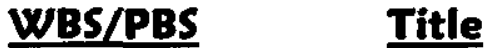

\subsection{2/TP11 Advanced Reactors Transition}

Description and Cause: All surveillance and maintenance (S\&M) resources were level loaded for the year. To date, no significant corrective maintenance activities have been required.

Impact: None.

Corrective Action: None.

\section{SCHEdule VARIANCE ANALYSIS: (\$0.0M)}

\section{WBS/PBS Title}

\subsection{2/TP11 Advanced Reactors Transition}

Description and Cause: None.

Impact: None.

Corrective Action: None.

\section{ISSUES}

There is nothing to report at this time.

\section{Baseline Change Requests Currently in Process}

\begin{tabular}{|l|c|c|c|c|c|c|c|c|c|}
\hline $\begin{array}{c}\text { PROJECT } \\
\text { CHANGE } \\
\text { NUMBER }\end{array}$ & $\begin{array}{c}\text { DATE } \\
\text { ORIGIN. }\end{array}$ & BCR TITLE & $\begin{array}{c}\text { FY00 } \\
\text { COST } \\
\text { IMPACT } \\
\text { SO00 }\end{array}$ & SCH & TECH & $\begin{array}{c}\text { DATE } \\
\text { TO CCB }\end{array}$ & $\begin{array}{c}\text { CCB } \\
\text { APR'VD }\end{array}$ & $\begin{array}{c}\text { RL } \\
\text { APR'VD }\end{array}$ & $\begin{array}{c}\text { CURRENT } \\
\text { STATUS }\end{array}$ \\
\hline & & Nothing to report. & & & & & & & \\
\hline & & & & & & & & \\
\hline
\end{tabular}

\section{Milestone ACHIEVEMENT}

Fiscal-year-to-date milestone performance (EA, DOE-HQ, and RL) shows that there are no milestones due.

\begin{tabular}{|l|}
\hline \\
Nothing to report. \\
\hline \\
\hline Nothing to report. \\
\hline
\end{tabular}




\section{MILESTONE EXCEPTION REPORT}

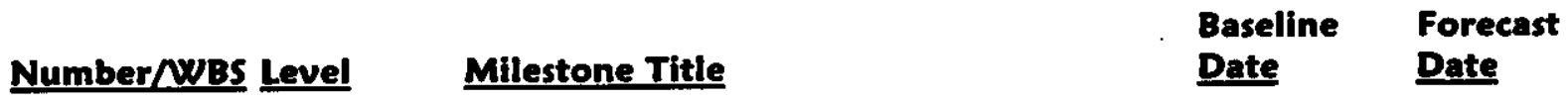

\section{Overdue - 0}

\section{FORECAST LATE - 0}

\section{Performance Objectives}

Nothing to report at this time.

\section{KEY INTEGRATION ACTIVITIES}

Nothing to report at this time. 
PHMC Environmental Management Performance Report - July 2000 Section F- EM-50 Sclence \& Technology Activities

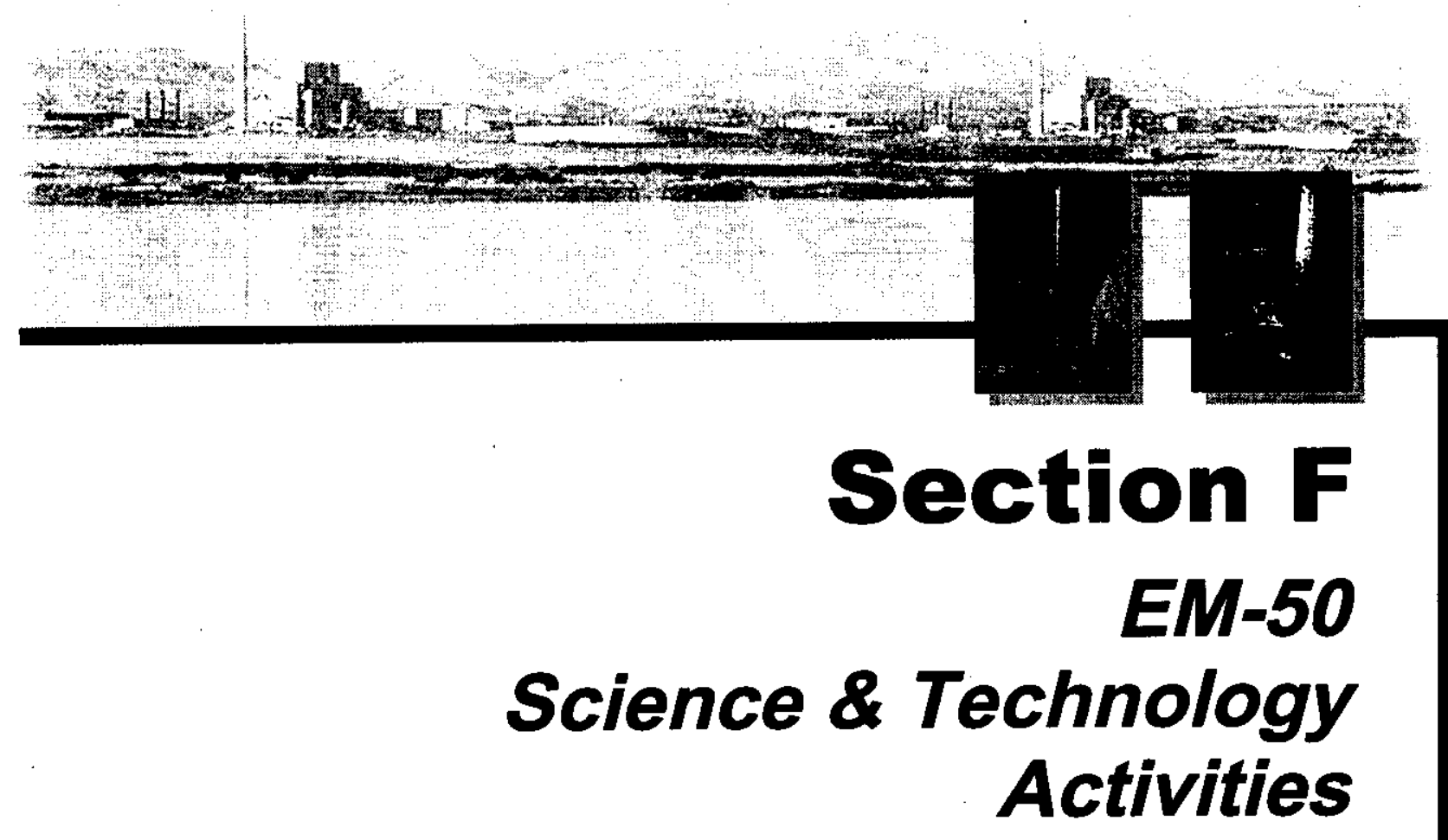




\section{EM-50 Milestone ACHIEVEMENT}

\begin{tabular}{|c|c|c|c|c|c|c|c|c|}
\hline \multirow[b]{2}{*}{ MILESTONE TYPE } & \multicolumn{4}{|c|}{ FISCAL YEAR-TO-DATE } & \multicolumn{3}{|c|}{ REMAINING SCHEDULED } & \multirow[b]{2}{*}{$\begin{array}{c}\text { TOTAL } \\
\text { FY } 2000\end{array}$} \\
\hline & Completed Early & $\begin{array}{c}\text { Completed On } \\
\text { Schedule }\end{array}$ & $\begin{array}{l}\text { Completed } \\
\text { Late }\end{array}$ & Overdue & $\begin{array}{c}\text { Forecast } \\
\text { Early }\end{array}$ & \begin{tabular}{|c|} 
Forecast \\
On \\
Schedule
\end{tabular} & $\begin{array}{c}\text { Forecast } \\
\text { Late }\end{array}$ & \\
\hline Enforceable Agreement & 0 & $\overline{0}$ & $\overline{0}$ & 0 & 0 & 0 & 0 & $\overline{0}$ \\
\hline DOE-HQ & of & 0 & 0 & 0 & of & $\pi$ & 0 & $T$ \\
\hline $\mathbf{R L}$ & of & 0 & $T$ & 2 & of & t & 0 & 4 \\
\hline Total Project & 0 & 0 & $\overline{1}$ & 2 & 0 & 2 & 0 & 5 \\
\hline
\end{tabular}

\section{EM-50 EXCEPTIONS}

$\begin{array}{lll}\text { Number Level Milestone Title } & \text { BAsEuNe } & \text { ForeCAST } \\ & \text { Date } & \text { Date }\end{array}$

OVERDUE - 2

49MW21/C-2 RL Produce Report Mapping the Matrix Space 11/15/99 Proposed 2.1.1 (AMT) in Hanford Waste Boxes

Deletion

Cause: Activities at WRAP were focused on preparing shipments to WIPP.

Impact: None.

Corrective Action: Funding for this TTP was returned to the Mixed Waste Focus Area. This task is cancelled.

49MW21/B-4 RL Issue Software Test Reports 12/01/99 Proposed
2.1.1 (AMT)
in Hanford Waste Boxes
Deletion

Cause: Activities at WRAP were focused on preparing shipments to WIPP.

Impact: None.

Corrective Action: Funding for this TTP was returned to the Mixed Waste Focus Area. This task is cancelled. 


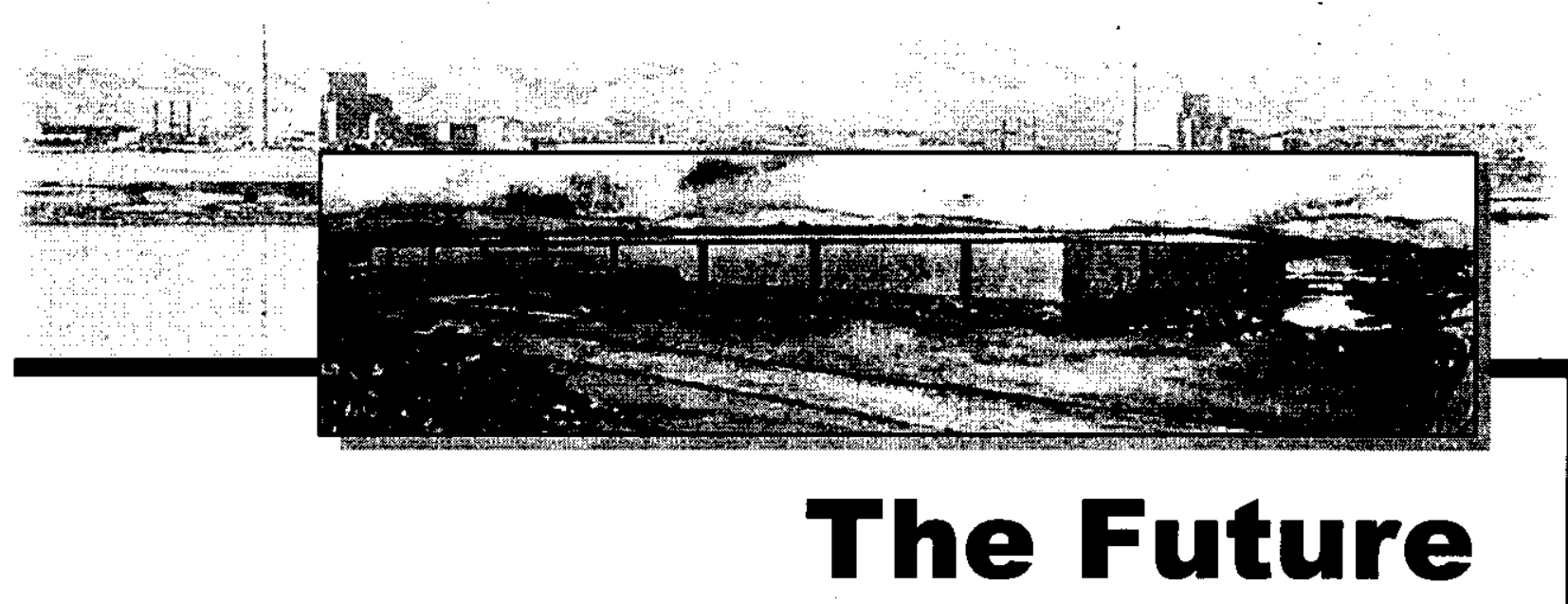

Hanford cleanup activities develop assets - people, experience, land, buildings, research and training facilities - that can have a positive affect on our future. They can help solve national and global problems in food

production, global warming, pollution and nuclear non-proliferation. The prime contractors and subcontractors at Hanford are implementing economic development initiatives aimed at weaning the Tri-Cities from

dependence on federal cleanup dollars. These initiatives are being supported with grants and by freeing up valuable site resources for use by the private sector. Examples of these initiatives are a new industrial building to attract new businesses to the area, job-creation efforts, and providing technical assistance to entrepreneurs. The Volpentest HAMMER

Training and Education Center is included in this outcome. HAMMER provides training for the Hanford Site cleanup mission and the DOE complex. The Center also augments economic diversification by creating a state-of-the-art regional training industry for students from across the nation and around the world. 


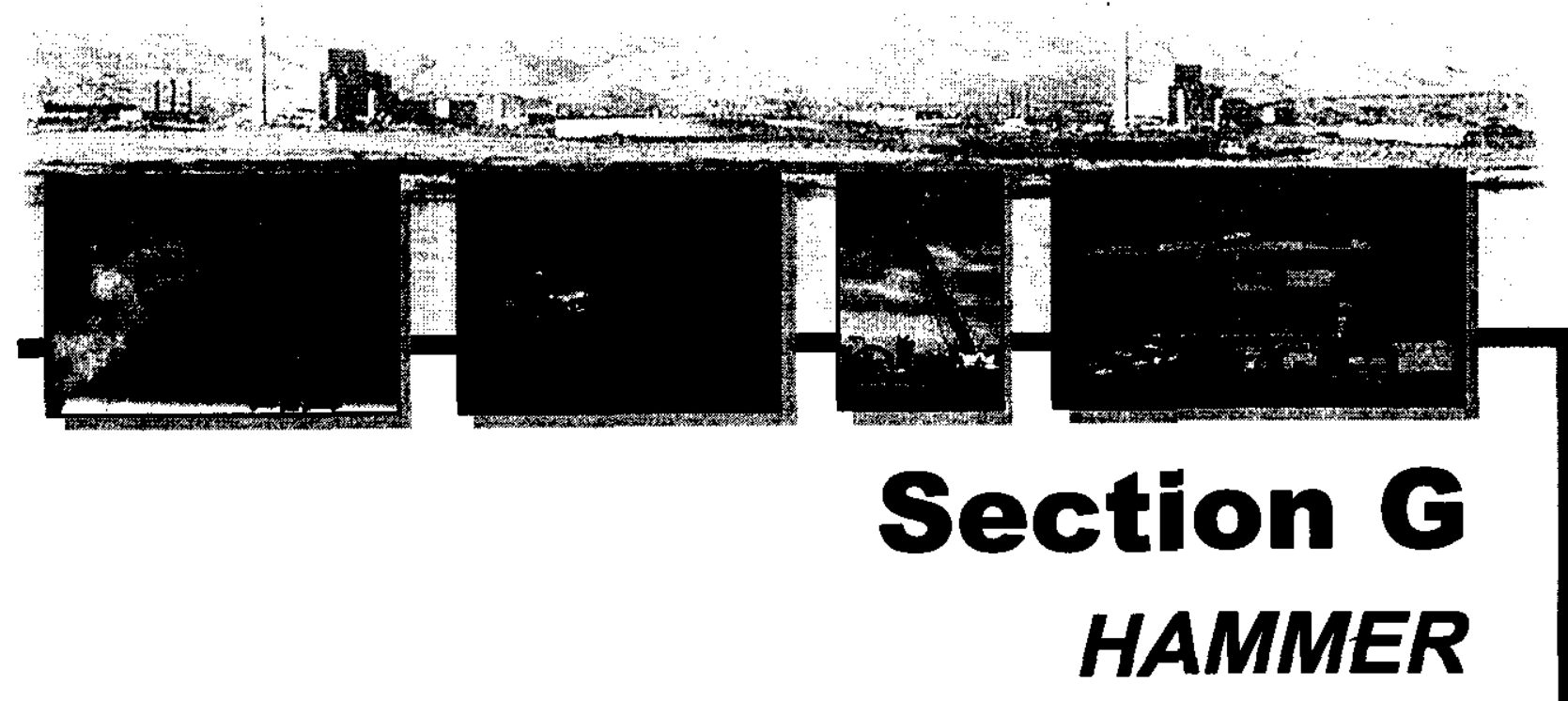

PROJECT MANAGERS

J.E. Ollero, RL (509) 376-3825

K.A. McGinnis, $\mathrm{FH}$

(509) 376-9403 


\section{SUMMARY}

The Hazardous Materials Management and Emergency Response (HAMMER) mission area consists of the HAMMER project, WBS 1.9.1.1, Project Baseline Summary (PBS) HM01.

NOTE: Unless otherwise noted, the Safety, Conduct of Operations, Milestone Achievement, and Cost/Schedule data contained herein is as of the end of May 2000. All other information is as of June 21, 2000.

Volpentest HAMMER's first priority is to deliver hands-on training to the Hanford workforce. During May one hundred seventy-one classes were conducted at the Volpentest HAMMER facility, for a total of 2,846 Hanford site student days. Highest attended health and safety classes included Hazardous Waste Operations, Respiratory Protection, Radiation Worker II Requalification, Basic Medic First Aid and Hanford Fire Department fire training. Overall satisfaction, rated on a scale of 1 to 5 based on level one evaluations, for the month of May: Course Content 4.46, Instructor(s) 4.59, and Facility 4.48.

A total of seven Hanford site Emergency Preparedness (EP) training courses were presented during May with a total of 167 students receiving training. EP classes presented included the Hanford Incident Command System, Building Emergency Director, Building Warden initial training. Two special EP training classes were presented to Bechtel Hanford Incorporated (BHI) personnel on May 10. These two Fluor Hanford courses, Hanford Incident Command System Initial and Building Emergency Director Initial training, were modified to incorporate BHI specific information before being presented to $\mathrm{BHI}$ personnel.

An Incident Command System (ICS) template has been developed and distributed to facility emergency preparedness organizations. This template was developed to provide guidance on how to incorporate an equivalent ICS overview into facility Emergency Response Organization (ERO) training, rather than sending ERO support personnel to the Hanford ICS training course. This template is not intended to be a direct replacement for the Hanford ICS course, but rather a foundation of ICS information upon which a facility or job specific ICS overview will be built.

A Federal Bureau of Investigation (FBI) tabletop drill dry-run was practiced May 24th and the actual FBI drill entitled, "Silent Thunder" was presented at the Volpentest HAMMER Training and Education Center on May 25th. This tabletop drill included FBI, Department of Energy (DOE), DOE contractors, Project Hanford Management Contractor (PHMC) employees and state and local agencies. The drill allowed for roles and responsibilities to be defined during an emergency which would include the FBI, such as the Weapons of Mass Destruction scenario utilized in this drill.

Non-DOE customers utilizing the Volpentest HAMMER facility for training activities, via the established HAMMER User Agreement process, included Energy Northwest, US Army Corp of Engineers, WA State Department of Transportation (DOT), PNNL, City of Richland Police Department, US Marine Corp. - Kennewick Office, and the Criminal Justice Training Commission. These training activities generated approximately $\$ 11,000$ of revenue for 
HAMMER. Generating revenue is included in the FY 2000 MultiYear Work Plan (MYWP) workscope activities for HAMMER, and will assist in reducing costs to DOE of providing site training.

Fiscal-year-to-date milestone performance (EA, DOE-HQ and RL) shows that one milestone (100 percent) was completed late.

\section{ACCOMPLISHMENTS}

- $\quad$ Trained 2,846 Hanford site student days at HAMMER.

- $\quad$ Presented seven Emergency Preparedness training courses.

- Developed ICS template for facility emergency preparedness organizations.

- Seven non-DOE customers utilized the Volpentest HAMMER facility for training activities.

HAMMER currently has no status to report in the areas of ISMS Status, Breakthroughs and Opportunities for Improvement.

\section{UPCOMING ACTIVITIES}

- $\quad$ The Fire Operations Product Line will be developing programs that employ HAMMER props to train individuals who must meet new technical rescue standards.

- The Fire Operations Product Line is working with the U.S. Forest Service to establish training plans for fire fighters that rappel from helicopters. The rappelling course may involve construction of a new prop that could be used for other types of training - SWAT responders and military customers, for instance.

- An International Customs class will be conducted in September 2000.

- A Global Positioning System equipment training course has been scheduled for August 2000.

- An Archeological Resources Protection Act Incident Investigation class has been scheduled for October 2000.

- Aerial robotics competition. 


\section{Cost Performance $(\$ M):$}

\begin{tabular}{|l|c|c|c|}
\hline & BCWP & ACWP & VARIANCE \\
\hline HAMMER & $\$ 3.7$ & $\$ 3.6$ & $\$ 0.1$ \\
\hline
\end{tabular}

The favorable cost variance of $\$ 0.1 \mathrm{M}$ ( 3 percent) is within established thresholds.

\section{SChedule Performance (\$M):}

\begin{tabular}{|l|c|c|c|}
\hline & BCWP & BCWS & VARIANCE \\
\hline HAMMER & $\$ 3.7$ & $\$ 4.0$ & $-\$ 0.2^{*}$ \\
\hline
\end{tabular}

*Rounding

The unfavorable schedule variance of $\$ 0.2 \mathrm{M}$ (6 percent) is within established thresholds.

\section{FY 2000 COSt/SChedule Performance - All Fund TyPes Cumulative to Date Status - $(\$ 000)$}

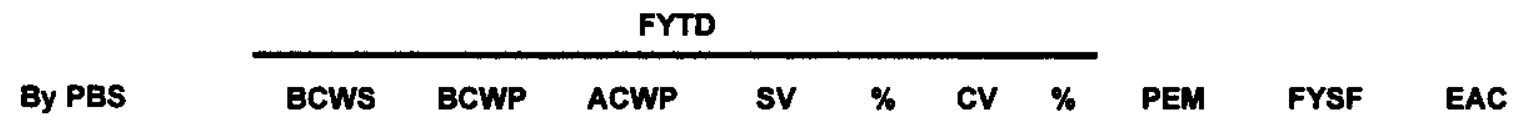

PBS HM01

WBS 1.9.1

Hammer $\begin{array}{llllllllllll}\$ 3,961 & \$ 3,719 & \$ 3,622 & \$(242) & -6 \% & \$ 98 & 3 \% & \$ 5,906 & \$ 5 & 5,892 & \$ 55,892\end{array}$

$\begin{array}{llllllllllllll}\text { Total } & \$ 3,961 & \$ 3,719 & \$ 3,622 & \$(242) & -6 \% & \$ 98 & 3 \% & \$ 5,906 & \$ 5,892 & \$ 5,892\end{array}$ 


\section{Cost/SChedule PerformanCe INDICES (MONTHLY 2000 AND FYTD)}

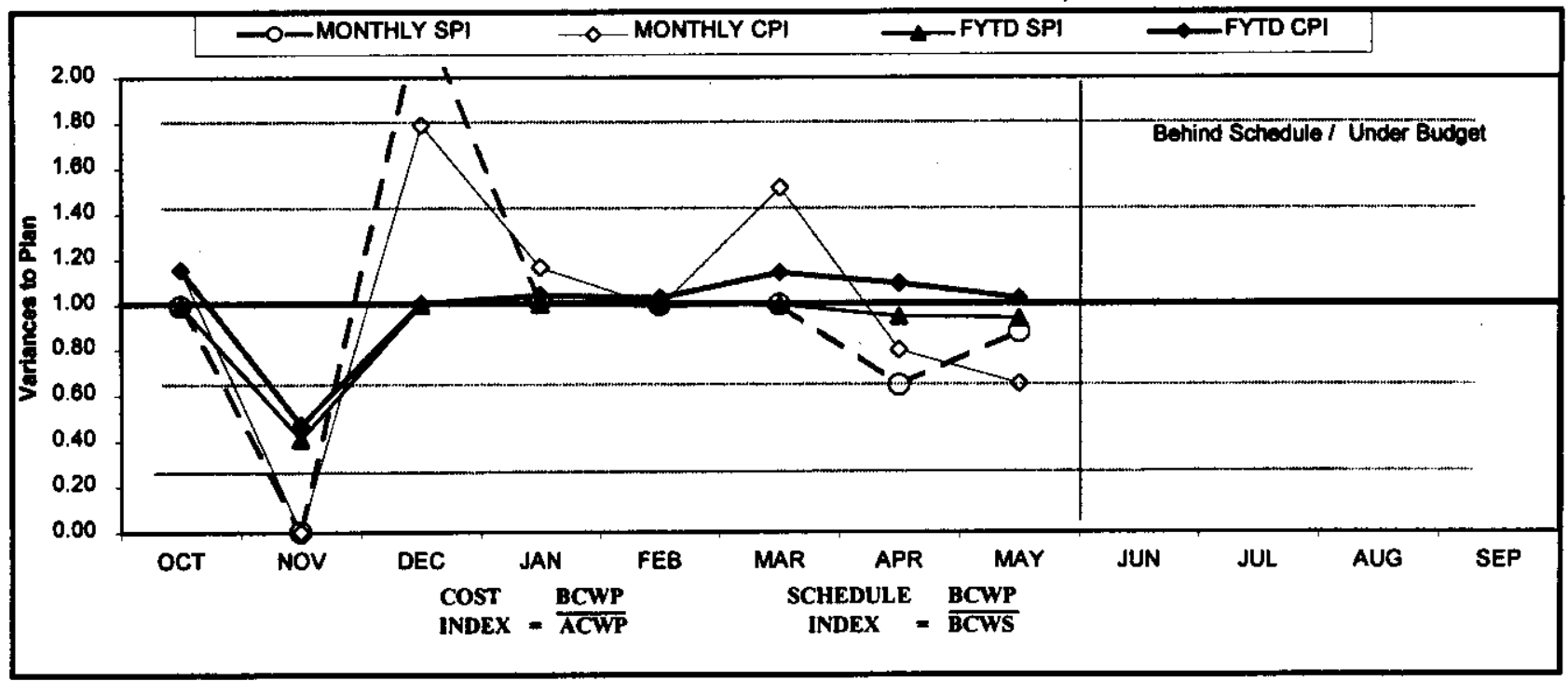

\begin{tabular}{|c|c|c|c|c|c|c|c|c|c|c|c|c|}
\hline PrY2000 & OCT & NOV & DEC & JAIN & FEB & MAR & APK & MAY & JUN & JUL & AUG & SEP \\
\hline MONTRIYYSPI & 0.99 & 0.00 & 2.28 & 1.01 & 1.00 & 1.00 & 0.64 & 0.88 & & & & \\
\hline MONTHLYCP & T.16 & 0.00 & 1.79 & T.16 & 0.99 & 1.51 & 0.80 & 0.65 & & & & \\
\hline FYTDSPI & 0.99 & 0.41 & 1.00 & 1.00 & 1.00 & 1.00 & 0.95 & 0.94 & & & & \\
\hline FYIDCPI & 7.16 & 0.47 & T.OT & 1.04 & 1.03 & T.14 & 1.09 & T.03 & & & & \\
\hline MONTRLYBCWS & 352 & 307 & 396 & 418 & $440^{\circ}$ & प्रा4 & 341 & 393 & 425 & 425 & 359 & 336 \\
\hline MONIHLYBCWP & 350 & - & 904 & 422 & 438 & 913 & 347 & 345 & & & & \\
\hline MONIFLY ACWP & 303 & 439 & 505 & 363 & 443 & 603 & 435 & 531 & & & & \\
\hline FYTDBCWS & 352 & 859 & 1,255 & T,673 & 2,113 & 3,027 & 3,568 & $3, \% 1$ & 4,386 & 4,810 & 5,369 & 5,906 \\
\hline FYTD BCWP & 350 & 350 & $\mathrm{T,254}$ & 1,676 & 2,114 & 3,027 & 3,375 & 3,719 & & & & \\
\hline FYTDACWP & 5303 & 5742 & $T, 247$ & 7,610 & 2,053 & 2,656 & 3,091 & 3,622 & & & & \\
\hline
\end{tabular}

\section{COST VARIANCE ANALYSIS: $(\$ 0.1 \mathrm{M})$}

\section{WBS/PBS TITLE}

\subsubsection{1/HMO1 HAMMER}

Description and Cause: The variance is within thresholds.

Impact: None

Corrective Action: None

\section{SCHEDULE VARIANCE ANALYSIS: $(-\$ 0.2 M)$}

\section{WBS TITLE}

\subsubsection{1/HMO1 HAMMER}

Description and Cause: The variance is within thresholds.

Impact: None.

Corrective Action: None. 


\section{ISSUES}

Nothing to report at this time.

\section{Baseline Change Requests Currently in Process $(\$ 000)$}

\begin{tabular}{|c|c|c|c|c|c|c|c|c|c|}
\hline $\begin{array}{c}\text { PROJECT } \\
\text { CHANGE } \\
\text { NUMBER }\end{array}$ & $\begin{array}{c}\text { DATE } \\
\text { ORIGIN. }\end{array}$ & \multicolumn{2}{|c|}{$\begin{array}{c}\text { FY00 } \\
\text { COST } \\
\text { IMPACT } \\
\text { S000 }\end{array}$} & SCH TITLE & TECH & $\begin{array}{c}\text { DATE } \\
\text { TO CCB }\end{array}$ & $\begin{array}{c}\text { CCB } \\
\text { APR'VD }\end{array}$ & $\begin{array}{c}\text { RL } \\
\text { APR'VD }\end{array}$ & $\begin{array}{c}\text { CURRENT } \\
\text { STATUS }\end{array}$ \\
\hline HMR-2000-002 & $4 / 12 / 00$ & Adjust FY 2000 MYWP Baseline & $(\$ 300)$ & $\mathrm{N}$ & $\mathrm{Y}$ & $4 / 24 / 00$ & $5 / 12 / 00$ & N/A & APProved \\
\hline \multicolumn{7}{|c|}{ ADVANCE WORK AUTHORIZATIONS } \\
\hline
\end{tabular}

\section{MILESTONE ACHIEVEMENT}

\begin{tabular}{|c|c|c|c|c|c|c|c|c|}
\hline \multirow[b]{2}{*}{ MLLESTONE TYPE } & \multicolumn{4}{|c|}{ FISCAL YEAR-TO-DATE } & \multicolumn{3}{|c|}{ REMAINING SCHEDULED } & \multirow[b]{2}{*}{$\begin{array}{l}\text { TOTAL } \\
\text { FY } 2000\end{array}$} \\
\hline & $\begin{array}{c}\text { Completed } \\
\text { Early }\end{array}$ & $\begin{array}{c}\text { Completed } \\
\text { On Schedule }\end{array}$ & $\begin{array}{c}\text { Completed } \\
\text { Late }\end{array}$ & Overdue & $\begin{array}{l}\text { Forecast } \\
\text { Early }\end{array}$ & $\begin{array}{c}\text { Forecast On } \\
\text { Schedule }\end{array}$ & $\begin{array}{l}\text { Forecast } \\
\text { Late }\end{array}$ & \\
\hline Enforceabie Agreement; & 0 & of & 0 & 0 & 0 & 0 & 0 & 0 \\
\hline DOE-HQ & 0 & 0 & 0 & 0 & 0 & 0 & 0 & \\
\hline RL & 0 & 0 & 1 & 0 & 0 & 4 & 0 & \\
\hline Total Project & 0 & 0 & 1 & $\overline{0}$ & $\overline{0}$ & 4 & 0 & \\
\hline
\end{tabular}

\section{Tri-Party Agreement / EA Milestones}

Nothing to report.

\section{DNFSB Commitments}

Nothing to report.

\section{MILESTONE EXCEPTION REPORT}

$\begin{array}{lll}\text { Number/WBS Level Milestone Title } & \begin{array}{l}\text { Baseline } \\ \text { Date }\end{array} & \begin{array}{l}\text { Forecast } \\ \text { Date }\end{array}\end{array}$

\section{OVerdue $\sim 0$}

Forecast LATE - 0 


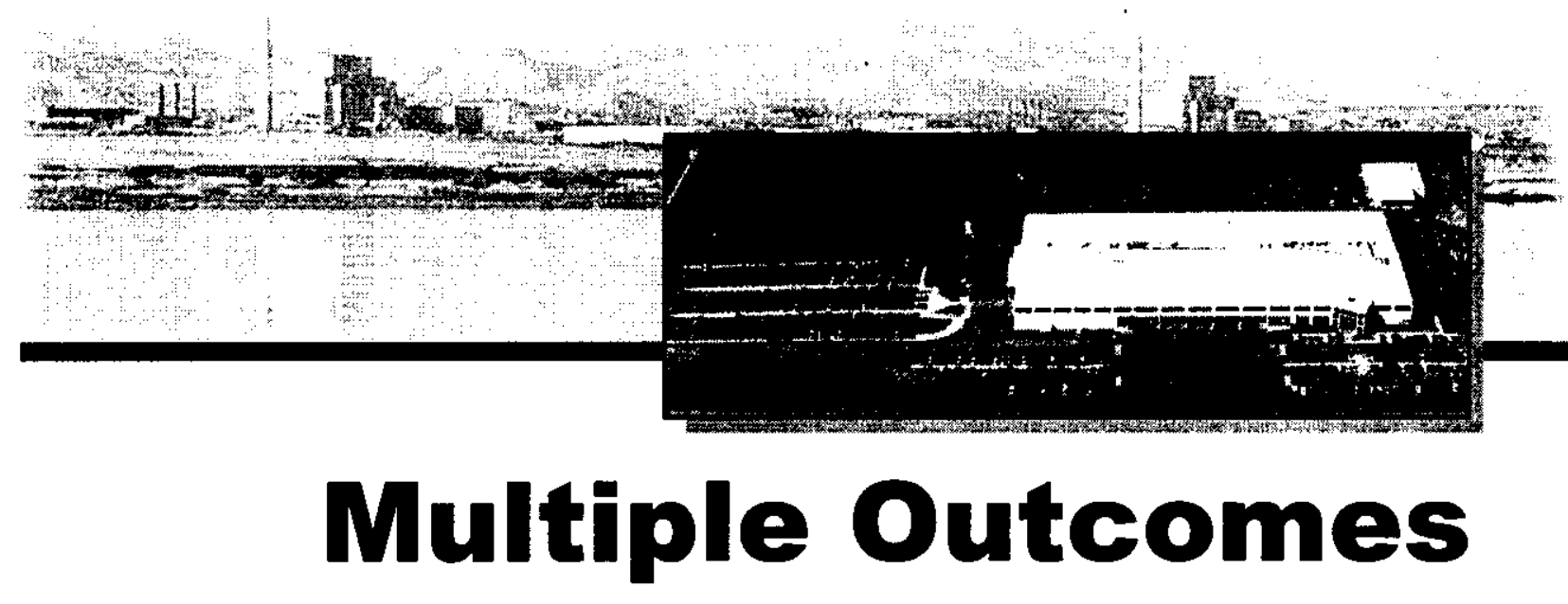

Projects that bridge more than one outcome are included here. These projects include Landlord, Support, and National Programs. Further descriptions are included in each section. 


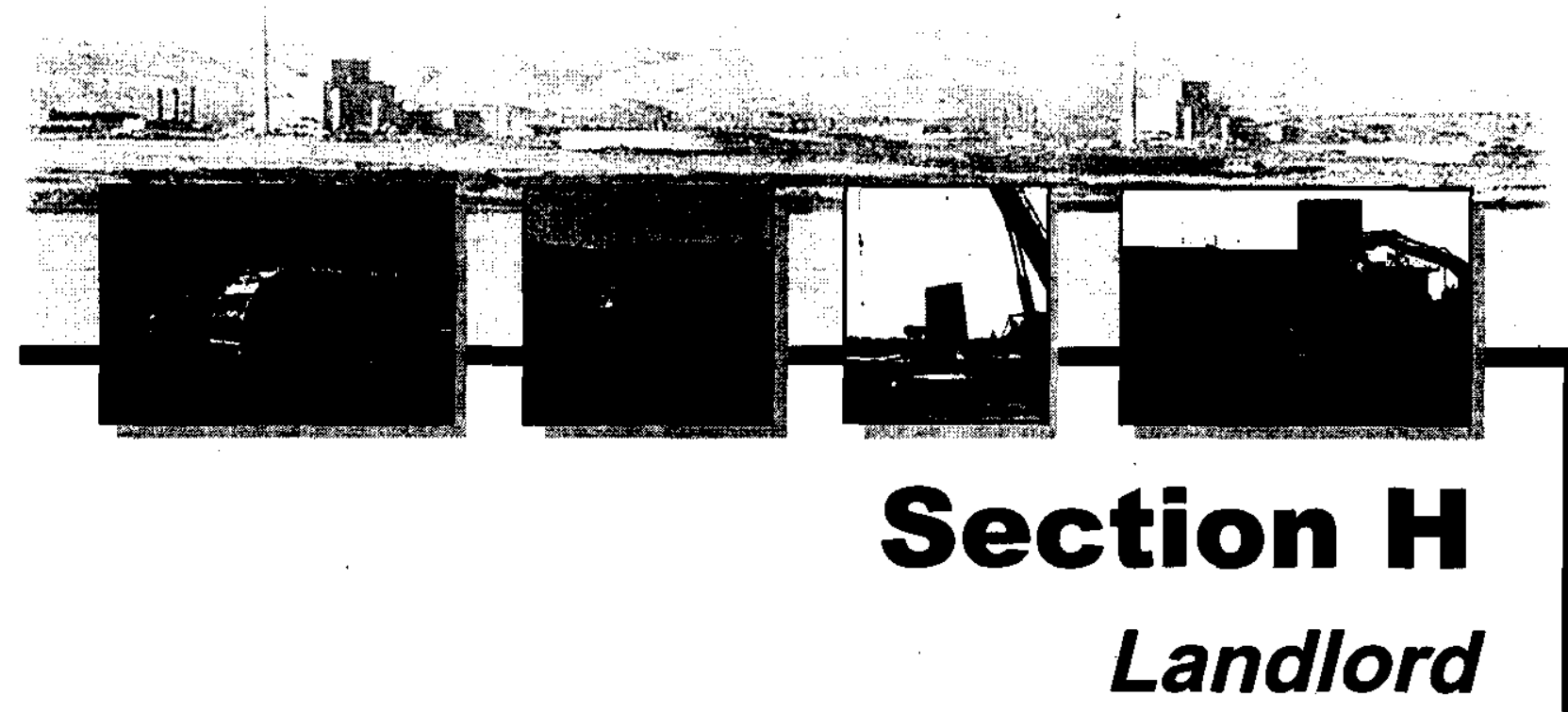

PROJECT MANAGERS

S.H. Wisness, RL (509) 373-9337

D.S. Kelly, FH (509) 376-7334 


\section{SUMMARY}

The Landlord mission area consists of the Landlord Project, WBS 1.5.1, Project Baseline Summary (PBS) RL-TP13.

NOTE: Unless otherwise noted, the Safety, Conduct of Operations, Milestone Achievement, and Cost/Schedule data contained herein is as of May 31, 2000. All other information is as of June $19,2000$.

Equipment Dispositioning Project activities include the disposition of one Well Car and one Flat Car in addition to surveillance and maintenance of the $212 \mathrm{R}$ rail siding where the majority of the regulated legacy rail cars are staged for future disposition. $\mathrm{RL}$ concurred with the recycling plan for the Well Car on May 17, which supports shipment to the offsite recycle vendor in late June. The Well Car disposition is approximately two months ahead of the scheduled completion (RL Milestone LLP-00-450). The disposition of up to six regulated flat cars (three Burlington Northern and three PX Cars) are being prepared for transfer to Tri-Cities Asset Reinvestment Company (TARC) to be reused by outside agencies. The final TARC agreement was signed by RL on May 16 and removal of the decking on the BN Flat Cars to allow "free release" started on May 25. The disposition of one flat car will be completed as scheduled by September 29. The stretch goal to prepare the additional five flat cars for reuse in FY 2000 is in jeopardy due to funding issues and timing with the TARC Agent to accept and process these rail cars.

Project L-312 “2101M, MO-235, \& Associated Buildings Storm Drainage Resolution” resolves storm drainage problems around facilities in 200 East and West Areas. This project includes the installation of catch basins, dry wells, grading, and paving around various facilities to properly drain stormwater away from the facilities. The fixed price construction contract was awarded on May 8. Work on the four sites in 200 East Area was initiated on June 8 and should be completed by July 10. The completion of construction is on schedule for August 4 (RL Milestone LLP-00435) and project closeout is planned by September 29.

Baseline Change Request (BCR) LPM-2000-005 was approved by RL on May 25. This BCR deleted RL Milestone LLP-00-420, "Transmit Finalized Comprehensive Land Use Plan (CLUP) to FH and RL by September 29, 2000". In turn, the work planned in FY 2001 to develop the CLUP supportive documents will be completed in FY 2000. RL received the draft CLUP implementing directives and associated procedures in September 1999, but support of a coordinated review in FY 2000 was not possible. These changes are consistent with the CLUP Environmental Impact Statement (EIS) Record of Decision to complete the implementing directive, procedures, and supporting documents by November 2, 2001 .

BCR LPM-2000-006 has been initiated to defer the Preliminary Engineering and Definitive Design preparation for Project L-327, "Export Water System Pumps Replacement" to fund the re-roofing of the 1163 Building Warehouse as directed by RL.

Fiscal-year-to-date milestone performance (EA, DOE-HQ, Field Office, and RL) shows one milestone $(100 \%)$ has been completed ahead of schedule. 


\section{ACCOMPLISHMENTS}

Completed RL Milestone LLP-00-425, "Complete Definitive Design for Project L-310, Replace Distribution Water Line to 200 West" two days ahead of the scheduled due date of May 26, 2000. Construction for this project is scheduled in FY 2001 and it replaces the existing 24-inch Export Water Line (EWL) between the 2901Y Valve House and the 200W Water Reservoir (approximately 2.5 miles long). The existing line is over 50 years old, has experienced several leaks in the past five years, and is the sole EWL to the 200 Area Water Treatment Plant.

The Landlord Project final Project Priority List (PPL) for FY 2001, 2002, and 2003 was completed on May 9 and was finalized on May 30. Overall this activity supports the FH budget deliverables for FY 2000. The annual update of the Multi-Year Work Plan (MYWP) will be initiated in June to support the completion of RL Milestone LLP-00-401, "Complete Bridge BCR in Support of MYWP Update by August 25, 2000".

\section{SAFETY}

FY 1999 performance was stable for case rates, but was very unstable in terms of severity (days away and restricted). FY 2000 is stable. 

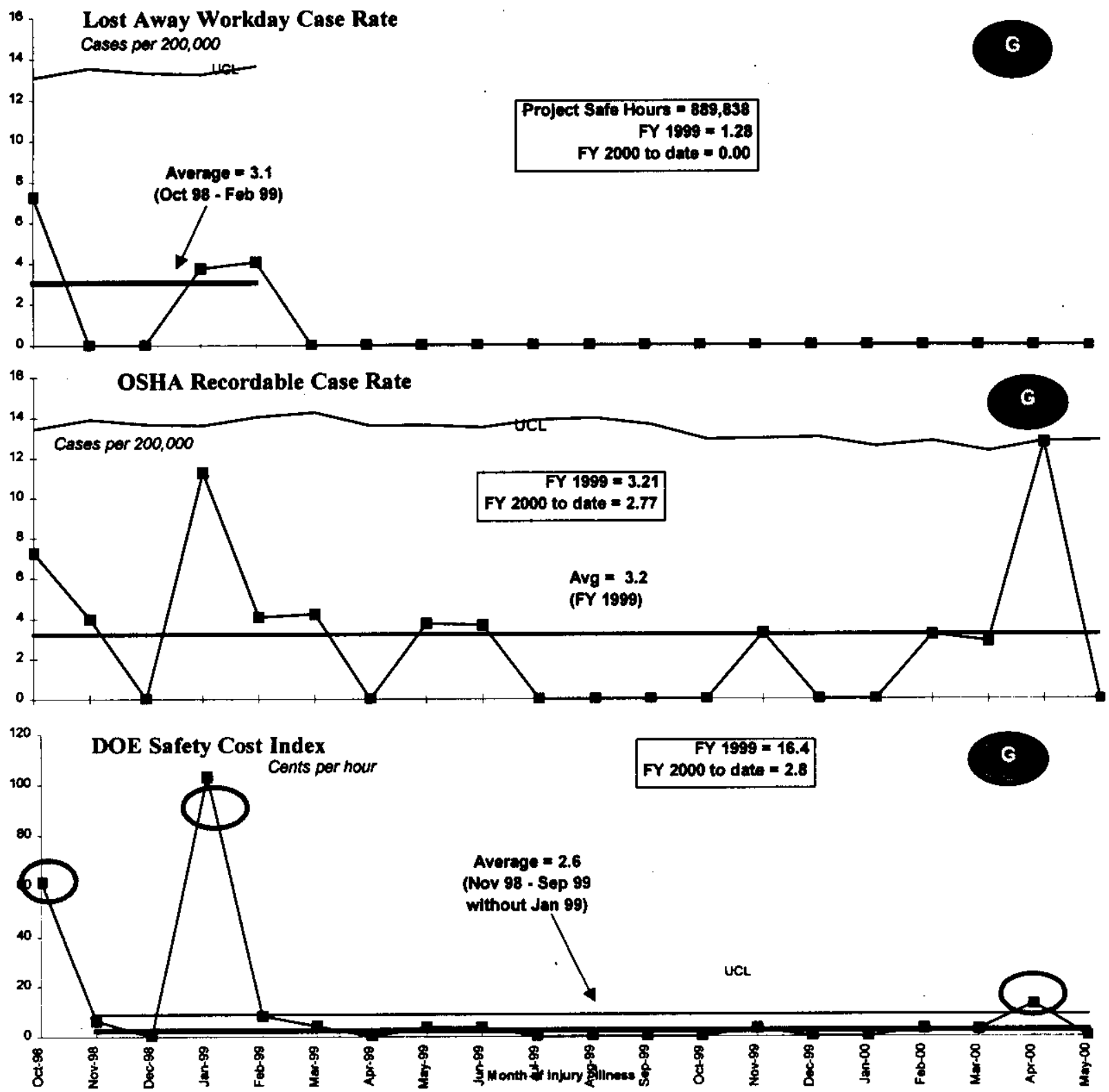


\section{ISMS STATUS}

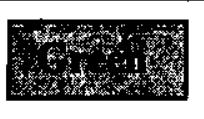

NOTE: The Infrastructure program includes the Landlord Project and the indirect Infrastructure. Both of these areas are covered under one ISMS program, therefore the ISMS activities described below are for the entire Infrastructure program, which includes Landlord.

- Continue to resolve the 16 concerns identified in DynCorp's ISMS Verification report. All 16 items are on schedule to be completed by July 1, 2000.

- Voluntary Protection Program (VPP) application for status has been submitted to DOE and the evaluation is tentatively scheduled for the middle of July.

\section{BREAKTHROUGHS / OPPORTUNITIES FOR IMPROVEMENT}

\section{Breakthroughs}

- Nothing to report at this time.

\section{Opportunities for Improvement}

- Nothing to report at this time.

\section{UPCOMING ACTIVITIES}

- Complete Project L-292, Emergency Preparedness Control Station (EPCS). This project retrofits the $100 \mathrm{~K} / \mathrm{D}$ Sirens to the new control system and changes the frequency for all the outdoor Site sirens so they can be controlled from a central point. Overall the project is 70 percent complete with four of the five sirens installed to date. The final siren will be installed by June 30th and system checkout and testing will be in July. Construction and system testing are planned to complete in July 2000.

- Complete Project L-312, “2101M, MO-235, and Associated Buildings Storm Drainage Resolution". Completion of construction is currently three weeks ahead of the scheduled completion date of August 4th (RL Milestone LLP-00-435).

\section{Cost Performance (\$M):}

\begin{tabular}{|l|c|c|c|}
\hline & BCWP & ACWP & VARIANCE \\
\hline Landlord & $\$ 7.4 \mathrm{M}$ & $\$ 5.4 \mathrm{M}$ & $\$ 2.0$ \\
\hline
\end{tabular}

The $\$ 2.0 \mathrm{M}$ (27 percent) favorable cost variance is mainly attributed to the auction of six cranes for which a credit was received. Further information at the PBS level can be found in the following Cost Variance Analysis details. 


\section{Schedule Performance (\$M):}

\begin{tabular}{|l|c|c|c|}
\hline & BCWP & BCWS & VARIANCE \\
\hline Landlord & $\$ 7.4 \mathrm{M}$ & $\$ 8.0 \mathrm{M}$ & $-\$ 0.7 \mathrm{M}^{*}$ \\
\hline
\end{tabular}

The \$0.7M (8 percent) unfavorable schedule variance is mainly attributed to Project L-297, Equipment Disposition Project, which is behind schedule due to a strategy change for dispositioning flat cars in achieving free release. The discovery of potential contamination of the lead shielding in the cask car was found resulting in a schedule delay.

\section{FY 2000 Cost/SChedule Performance - All Fund Types Cumulative to Date Status - $(\$ 000)$}

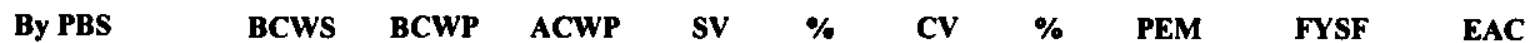

$\begin{array}{llllllllllllllllllll}\text { PBS TP13 } & \text { Landlord } & S & 8,047 & S & 7,385 & \$ & 5,395 & \$ & (662) & -8 \% & \$ & 1,990 & 27 \% & \$ & 14,109 & \text { S } & 12,165 & \$ & 13,944\end{array}$

$\begin{array}{llllllllllllllllllll}\text { Total } & \$ & 8,047 & \$ & 7,385 & \$ & 5,395 & \text { S } & (662) & -8 \% & \$ & 1,990 & 27 \% & \text { S } & 14,109 & \$ & 12,165 & \text { S } & 13,944\end{array}$

Note: Landlord EAC includes carryover funding of $\$ 1,646 \mathrm{~K}$ for committed GPP's.

\section{Cost/Schedule Performance Indices (MONTHLY AND FYTD)}

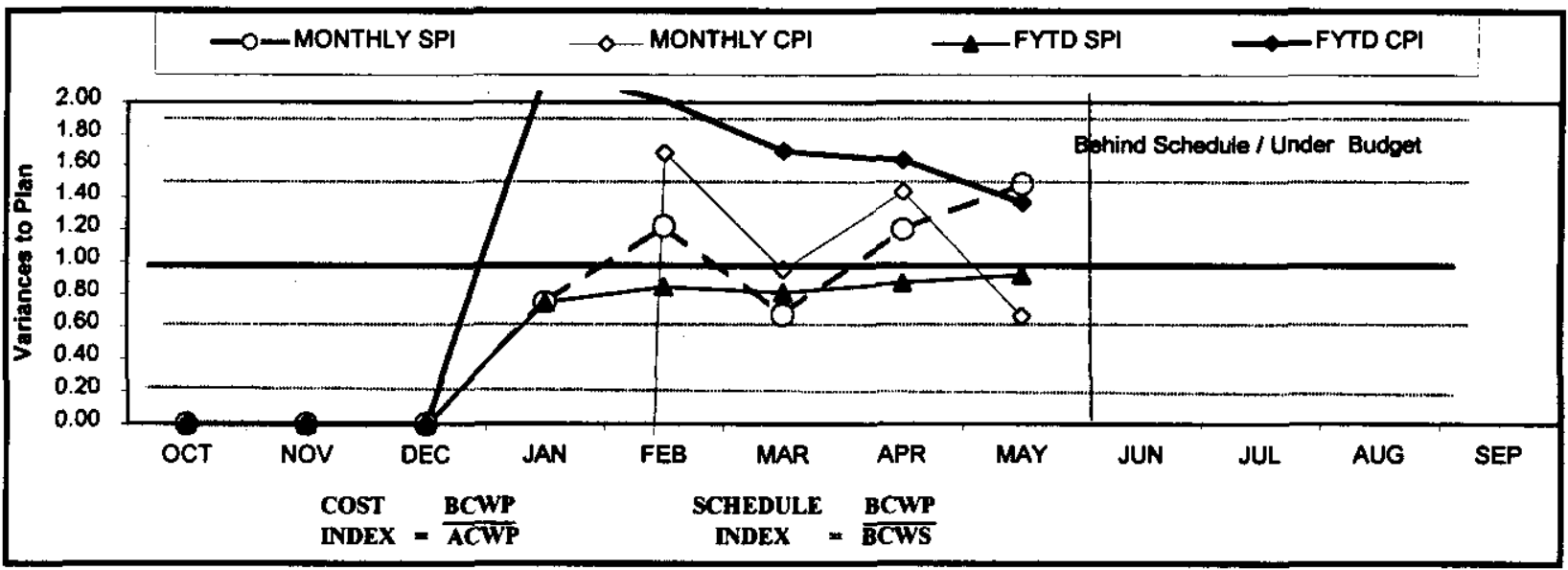

\begin{tabular}{|c|c|c|c|c|c|c|c|c|c|c|c|c|}
\hline FY 200 & OCT & NOV & DEEC & JAN & F2: & MAR & APK & MAY & JUN & JUL & AUG & SEP \\
\hline MONIFICYSPI & 0.00 & 0.00 & 0.00 & 0.75 & 1.22 & 0.67 & 1.20 & 1.48 & & & & \\
\hline MONTHLYCPT & 0.00 & 0.00 & 0.00 & -9.23 & 7.68 & 0.95 & 1.43 & 0.66 & & & & \\
\hline FYTDSPI & 0.00 & 0.00 & 0.00 & 0.75 & 0.84 & 0.81 & 0,87 & 0.92 & & & & \\
\hline MONTPLY BCWS & 30 & so & 30 & 53,994 & $\$ 1,016$ & \$1,269 & $\$ 1, \pi 5$ & $\$ 653$ & 3974 & $\$ 1,385$ & 31,774 & $\$ 1,930$ \\
\hline MONTHILYECWP & 30 & 30 & 30 & \$2,98! & $\$ 1,243$ & $\$ 854$ & $\$ 1,339$ & 3968 & & & & \\
\hline MONTHLY ACWP & (\$197) & $\$ 943$ & $\$ 767$ & (\$153) & $\$ 741$ & $\$ 899$ & $\$ 934$ & $\$ 1,464$ & & & & \\
\hline FYTDBCWS & $\$ 0$ & 50 & 30 & $\$ 3,994$ & $\$ 5,010$ & 56,279 & $\$ 7,394$ & $\$ 8,047$ & $39,020^{\circ}$ & 310,405 & \$T2, 180 & $\$ 14,109$ \\
\hline FYTDBCWP & 30 & So & 30 & 52,981 & $\mathbf{5 4 , 2 2 4}$ & 35,078 & $\$ 6.417$ & $\$ 7,385$ & & & & \\
\hline FYTD ACWP & (\$197) & $\$ 746$ & \$1,513 & 51,358 & $\$ 2,099$ & $\$ 2,998$ & $\$ 3,932$ & $\$ 5,395$ & & & & \\
\hline
\end{tabular}




\section{COSt VARIANCE ANALYsis: $\quad(+\$ 2.0 M)$}

\section{WBS/PBS}

\subsection{1/TP-13}

\section{Description/C} in of six cranes in which a credit was received. Procurement of one new crane will be received next year (long lead procurement). In addition, the Municipal Planning Process and the Infrastructure Plan (IP) are under-running because they are behind schedule. Efforts to hire a subcontractor in lieu of using internal labor to complete the IP are underway. Demolition cost for building 609C for Project L-270, Emergency Services Renovation was not as high as planned. Workscope for this project is being completed on a fixed price contract and construction cost will be higher than planned, reducing the cost variance.

Impact: No impact to overall project and/or final cost.

Corrective Action: A requisition has been entered into Passport to procure the new crane, which replaces the six sold at auction. A BCR is in process that defers workscope and also reprograms line item funding on completed projects.

\section{SCHEDUle VARIANCE ANALYSIS: (-\$0.7M)}

\section{$\underline{\text { WBS/PBS }} \quad$ Title}

\subsection{1/TP13 Landlord}

Description /Cause: The $\$ 0.7 \mathrm{M}(8$ percent) unfavorable schedule variance mainly attributed to Project L-297, Equipment Disposition Project, which is behind schedule due to a strategy change for dispositioning flat cars in achieving free release and the discovery of potential contamination of the lead shielding in the casks car was found resulting in a schedule delay. Also, the Municipal Planning Process and the Infrastructure Plan are behind schedule due to priorities related to completion of the Comprehensive Land Use Plan. Construction to install a new system to replace chlorinating system at the 200 West Area Water Treatment Plant was originally planned as a fixed price contract. A Plant Forces Work Review deemed the work to be plant forces, resulting in a schedule variance. Definitive Design has been completed and procurement contracts started for materials.

Impact: No impact to overall project schedule.

Corrective Action: None.

\section{ISSUES}

There are no technical, DOE, Regulator or external issues identified at this time. 
Baseline Change Reguests Currently in Process $(\$ 000)$

\begin{tabular}{|c|c|c|c|c|c|c|c|c|c|}
\hline $\begin{array}{l}\text { PROJECT } \\
\text { CHANGE } \\
\text { NUMBER }\end{array}$ & $\begin{array}{c}\text { DATE } \\
\text { ORIGIN. }\end{array}$ & BCR TITLE & $\begin{array}{c}\text { FY00 } \\
\text { COST } \\
\text { IMPACT } \\
\text { S000 }\end{array}$ & SCH & TECH & $\underset{\text { CCB }}{\text { DATE TO }}$ & $\begin{array}{c}\text { CCB } \\
\text { APR'VD }\end{array}$ & $\begin{array}{c}\mathbf{R L} \\
\mathbf{A P R} \mathbf{R}^{\prime} \mathbf{D}\end{array}$ & $\begin{array}{l}\text { CURRENT } \\
\text { STATUS }\end{array}$ \\
\hline LPM-00-001 & $11 / 3 / 99$ & $\begin{array}{l}\text { MYWP Baseline Modification } \\
\text { (Bridge BCR FY00, 01, 02) }\end{array}$ & $\$ 4,642$ & $\mathrm{X}$ & $\mathbf{X}$ & $1 / 11 / 00$ & $1 / 14 / 00$ & $1 / 27 / 00$ & $\begin{array}{l}\text { Approved by } \\
R L\end{array}$ \\
\hline LPM-00-003 & $12 / 8 / 99$ & Document FY99 Carryover Funds & $\$ 1,793$ & & $\mathbf{x}$ & $12 / 13 / 00$ & $1 / 3 / 00$ & $1 / 3 / 00$ & $\begin{array}{l}\text { Approved by } \\
\text { RL }\end{array}$ \\
\hline LPM-00-005 & $3 / 23 / 00$ & $\begin{array}{l}\text { Document Rate Increase, Funding } \\
\text { Reductions, and Impacts to } \\
\text { Milestones }\end{array}$ & $s<318>$ & $\mathbf{X}$ & $\mathbf{x}$ & $4 / 13 / 00$ & $4 / 27 / 00$ & $5 / 25 / 00$ & $\begin{array}{l}\text { Approved by } \\
\mathrm{RL}\end{array}$ \\
\hline LPM-00-006 & $5 / 30 / 00$ & $\begin{array}{l}\text { Added Scope for } 1163 \text { Re-roof, } \\
\text { Defere Definitive Design for L- } \\
\text { 327, Delete Milestone LLP-00-465 }\end{array}$ & $\$ 180$ & $\mathbf{x}$ & $\mathrm{x}$ & $6 / 8 / 00$ & $6 / 8 / 00$ & & $\begin{array}{l}\text { Approved by } \\
\text { FH CCB and } \\
\text { Submitted to } \\
\text { RL } 6 / 12 / 00\end{array}$ \\
\hline \multicolumn{10}{|c|}{ ADVANCE WORK AUTHORIZATIONS } \\
\hline & & N/A & & & & & & & \\
\hline
\end{tabular}

\section{MILESTONE ACHIEVEMENT}

\begin{tabular}{|r|r|r|r|r|r|r|r|r|}
\hline \multirow{2}{*}{ MI LES TONE TYPE } & \multicolumn{2}{|c|}{ FISCAL YEAR-TO-DATE } & \multicolumn{3}{c|}{ REMAINING SCHEDULED } & \\
\cline { 2 - 8 } & $\begin{array}{r}\text { Completed } \\
\text { Early }\end{array}$ & $\begin{array}{c}\text { Completed } \\
\text { On Schedule }\end{array}$ & $\begin{array}{c}\text { Completed } \\
\text { Late }\end{array}$ & Overdue & $\begin{array}{c}\text { Forecast } \\
\text { Early }\end{array}$ & $\begin{array}{c}\text { Forecast } \\
\text { On } \\
\text { Schedule }\end{array}$ & $\begin{array}{c}\text { Forecast } \\
\text { Late }\end{array}$ & $\begin{array}{c}\text { TOTAL } \\
\text { FY 2000 }\end{array}$ \\
\hline Enforceable Agreement & 0 & 0 & 0 & 0 & 0 & 0 & 0 & 0 \\
\hline DOE-HQ & 0 & 0 & 0 & 0 & 0 & 0 & 0 & 0 \\
\hline RL & 1 & 0 & 0 & 0 & 0 & 9 & 0 & 10 \\
\hline Total Project & 1 & 0 & 0 & 0 & 0 & 9 & 0 & 10 \\
\hline
\end{tabular}

\section{Tri-Party Agreement / EA Millestones}

Nothing to report.

DNFSB Commitments

Nothing to report.

\section{MILESTONE EXCEPTION REPORT}

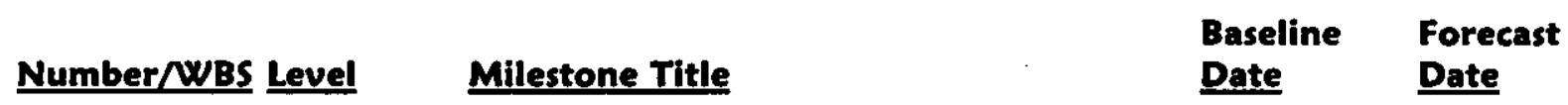

\section{OVerdue - 0}

FORECAST LATE - 0 


\section{Performance Objectives}

The items listed below are not Performance Incentives. They are performance goals (i.e., milestones and goals between $\mathrm{FH}$ and the subcontractor).

\begin{tabular}{|c|c|c|}
\hline Outcome & Performance Goals & Status \\
\hline \multirow{6}{*}{$\begin{array}{l}\text { Restore the River } \\
\text { Corridor for } \\
\text { Multiple Uses } \\
\text { \& } \\
\text { Transition the } \\
\text { Central Plateau }\end{array}$} & $\begin{array}{l}\text { Replace } 1,500 \text { Feet of } 2 \text {-inch Sanitary } \\
\text { Water Line from } 272 \mathrm{AW} \text { Building } \\
\text { Along Canton Ave. in } 200 \text { East }\end{array}$ & $\begin{array}{l}\text { Definitive Design was completed on April } 18 \text {, ten days } \\
\text { ahead of schedule. The current status supports construction } \\
\text { completion on schedule by September } 29,2000 \text {. }\end{array}$ \\
\hline & $\begin{array}{l}\text { Provide Vegetation and Animal } \\
\text { Control to Reduce/Minimize the } \\
\text { Spread of Contamination }\end{array}$ & $\begin{array}{l}\text { Project has treated 3,000 acres of residual and non-selective } \\
\text { type spraying across the Site this fiscal year to date and } \\
\text { cleared tumbleweeds at } 16 \text { sites. Continue to monitor } 699 \\
\text { rodent bait stations and } 48 \text { termite and ant control stations. }\end{array}$ \\
\hline & $\begin{array}{l}\text { Disposition } 38 \text { Abandoned Legacy } \\
\text { Non-Radioactive Waste Sites }\end{array}$ & $\begin{array}{l}\text { Fieldwork to clean up the small site near T-Tank Farms in } \\
200 \mathrm{~W} \text { was completed. Cutting off the contaminated portion } \\
\text { of scrap metal minimized radioactive waste from the project. } \\
\text { The clean material can be recycled. It is hoped that the } \\
\text { actions taken will preclude entry of the site into the Waste } \\
\text { Information Data System (WIDS) database or will enable it } \\
\text { to be entered as rejected since no further actions are } \\
\text { necessary. }\end{array}$ \\
\hline & $\begin{array}{l}\text { Complete Installation of } 100 \mathrm{~K} / \mathrm{D} \\
\text { Emergency Notification Sirens which } \\
\text { will Complete the Total Integration of } \\
\text { All Outside Sirens }\end{array}$ & $\begin{array}{l}\text { Overall the project is } 70 \text { percent complete with four of the } \\
\text { five sirens installed to date. The final siren will be installed } \\
\text { by June } 30 \text { th and system checkout and testing will be in } \\
\text { July. Construction and system testing are planned to } \\
\text { complete in July } 2000 \text {. }\end{array}$ \\
\hline & $\begin{array}{l}\text { Complete Emergency Services } \\
\text { Renovation of the } 200 \text { Area Fire } \\
\text { Station }\end{array}$ & $\begin{array}{l}\text { Electricians isolated all electrical wires to the electrical } \\
\text { panels in } 609 \mathrm{~A} \text { and as a further safety precaution a total } \\
\text { electrical outage was taken on May } 31 \text { to remove the last } \\
\text { portion of the west wall of } 609 \mathrm{~A} \text {. Therefore, all demolition } \\
\text { within } 609 \mathrm{~A} \text { to support the setting of the new building } \\
\text { columns is complete. During review of the electrical } \\
\text { submittal, it was discovered the electrical transformers were } \\
\text { undersized for the planned loads and required a design } \\
\text { change to correct the error. The design change was } \\
\text { approved on May } 30 \text { and transmitted to Thompson } \\
\text { Mechanical to prepare a contract change estimate. }\end{array}$ \\
\hline & $\begin{array}{l}\text { Shutdown Approx. } 20 \text { Vacant Office } \\
\text { Facilities - Deactivate } 25 \text { Vacant } \\
\text { Facilities }\end{array}$ & $\begin{array}{l}15 \text { of the planned } 20 \text { facilities have been shutdown for the } \\
\text { fiscal year and } 22 \text { of the planned } 25 \text { facilities have been } \\
\text { deactivated. Project remains on schedule. }\end{array}$ \\
\hline $\begin{array}{l}\text { Put Assets to } \\
\text { Work for the } \\
\text { Future }\end{array}$ & $\begin{array}{l}\text { Disposition One Well Car and One } \\
\text { Flat Car - Surveillance and } \\
\text { Maintenance of Legacy Rail Cars at } \\
\text { 212R Awaiting Disposition }\end{array}$ & $\begin{array}{l}\text { RL concurred with the recycling plan for the Well Car on } \\
\text { May } 17 \text {, which supports shipment to the offsite recycle } \\
\text { vendor in late June. The final TARC agreement was signed } \\
\text { by RL on May } 16 \text { and removal of the decking on the BN } \\
\text { Flat Cars to allow "free release" started on May } 25 \text {. The } \\
\text { disposition of one flat car will be completed as scheduled by } \\
\text { September } 29 \text {. The stretch goal to prepare the additional } \\
\text { five flat cars for reuse in FY } 2000 \text { is in jeopardy due to } \\
\text { funding issues and timing with the TARC Agent to accept } \\
\text { and process these rail cars. }\end{array}$ \\
\hline
\end{tabular}




\section{KEY INTEGRATION ACTIVITIES}

Continue to support RL on the following activities to plan and manage land and resources for the Hanford Site:

- Establishing a Hanford Site Planning Advisory Board made up of cooperating agencies and Tribal representatives to support implementation of the Comprehensive Land Use Plan (CLUP).

- Developing Area and Resource Management Plans (e.g., Landlord Infrastructure Master Plan) to support implementation of the CLUP.

- Assisting DOE in identifying mandatory requirements functions, interfaces and relationships for successful long-range planning and management of Site land and resources.

- Developing DOE Management System Descriptions for land use.

- Coordinating reviews and approvals for the use of land on Site.

- Developing and administering Real Estate documents (e.g., licenses, leases, easements, and permits). 


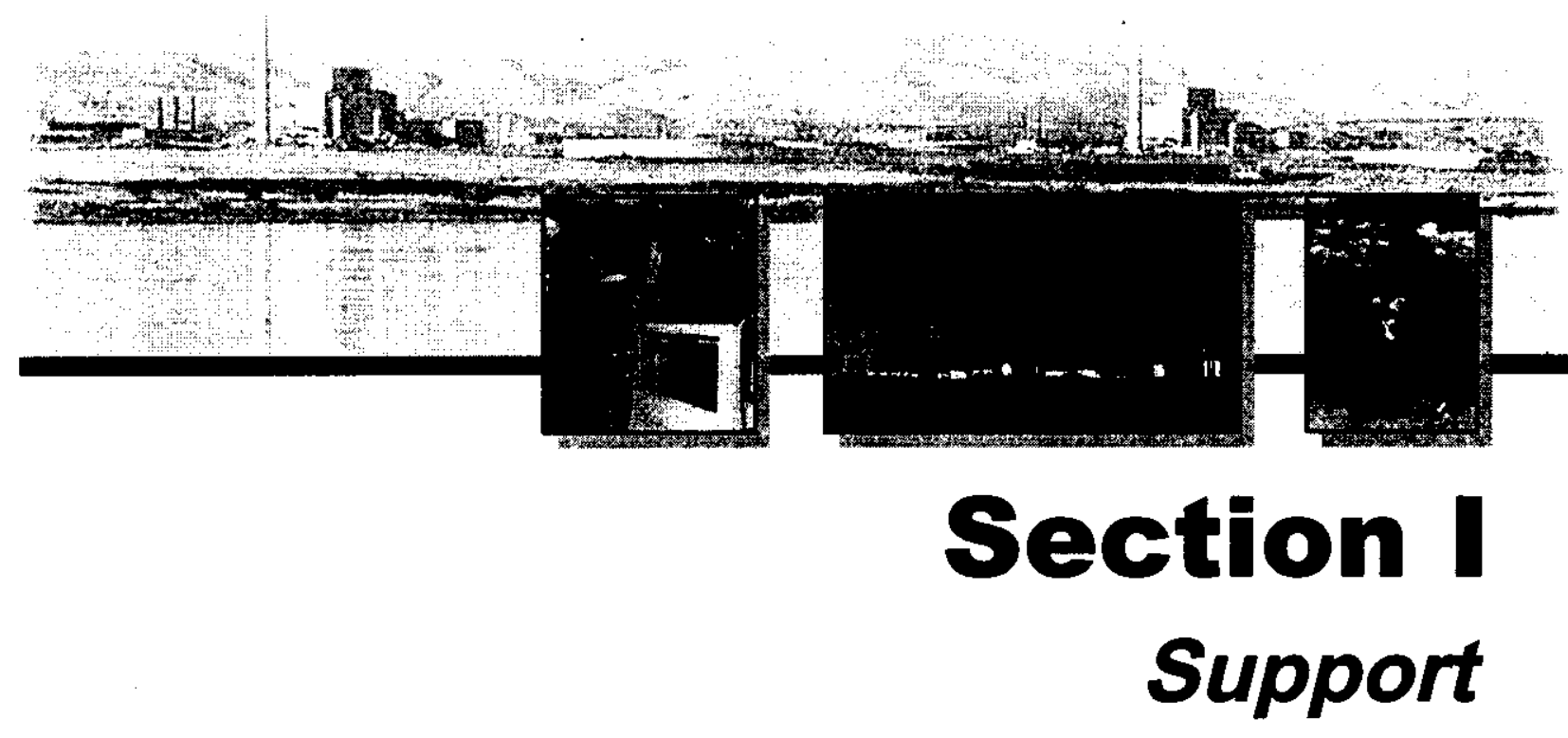

PROJECT MANAGERS

SP\&I W.W. Ballard, RL (509) 376-6657 G.J. McCleary, FH (509) 372-8385

SSE W.W. Ballard, RL (509) 376-6657

M.L. Grygiel, FH (509) 372-2983

ECP S.H. Wisness, RL (509) 373-9337

J.W. Hales, FH $\quad$ (509) 376-4069

PSRP S.H. Wisness, RL (509) 373-9337 R.L. Dirkes, PNNL (509) 376-8177 


\section{SUMMARY}

Mission Support, Project Baseline Summary (PBS) OT01, consists of four sub-projects:

- $\quad$ Planning and Integration [Work Breakdown]

- $\quad$ Structure (WBS 1.8.2.1)]

- $\quad$ Systems Engineering (WBS 1.8.2.2)

- $\quad$ Environmental Compliance (WBS 1.8.2.3)

The Environmental Compliance Program is composed of two elements. These two elements were stand-alone programs known as the Hanford Environmental Management Program (HEMP) and the Effluent and Environmental Monitoring Program (EEM) prior to FY99. Although there is a single program, these elements retain their identity on the Integrated Priority List as two separate Units of Analysis.

- $\quad$ Public Safety and Resource Protection (WBS 1.8.2.4)

In addition, Richland Directed Activities, PBS OT04, is included in this section. It consists of general site requirements such as:

- $\quad$ Resource Conservation and Recovery Act [RCRA] Mixed Waste Fee (management fee)

- Department of Health (DOH) Oversight (air monitoring)

- Downwinder Litigation

- $\quad$ Permits/site support [State of Washington (air emissions program)]

- $\quad$ Emergency Preparedness Grants

- State of Oregon Hanford Oversight

- $\quad$ Payment in Lieu of Taxes

- Hanford Advisory Board/Miscellaneous Grants (Hanford Openness Panel)

- Uranium Mass Balance Project (Paducah)

- National Security Analysis (formerly declassification of documents)

- $\quad$ Other minor financial assistance grants and contracts.

NOTE: Unless otherwise noted, the Safety, Conduct of Operations, Milestone Achievement, and Cost/Schedule data contained herein is as of May 31, 2000. All other information is as of June $17,2000$.

Fiscal-year-to-date milestone performance (EA, DOE-HQ, and RL) shows that 25 of 29 milestones ( 87 percent) were completed on or ahead of schedule, 3 milestone (10 percent) was completed late and 1 milestone ( 3 percent) is overdue. The Milestone Achievement details, found following cost and schedule variance analysis, provide further information on all milestone types. 


\section{Site Planning and Integration (SP\&I)}

Resource Loaded Summary Schedule - Development of the Resource Loaded Summary Schedule was completed for delivery as scheduled on May 11, 2000. It contains summaries of all work for FH, BHI, and PNNL, as well as ties to ORP and off-site deliverables. The intent is to use this schedule to validate "what if" scope scenarios developed by a joint RL/Prime Contractor Schedule Options Team.

Follow-up meetings have been held with the Mission Planning Division to discuss the schedule updating cycle, and associated products required for the annual work plan update. The next task, planned for early July, is utilizing the schedule product tool in working with the Schedule Options Team on workscope change scenarios.

CMM Update Allows Project Baseline Control - Updates to the Central Milestone Module (CMM) now link the system to the Baseline Change Control (BCC) Module and allow field project control personnel to add/delete/modify milestones based on approved Baseline Change Requests (BCR). Prior to this update, all changes to milestones had to be executed by SP\&I staff. These updates are significant because implementation of baseline changes in CMM were not always concurrent with corresponding project schedule and cost baseline implementation(s); greater accuracy in the future is now anticipated.

Project Baseline Updates Implemented - Updates of project baselines were implemented into project cost baselines in May based upon approval of BCRs. These changes were based on the impacts of company overhead rate and organizational changes associated with the PHMC restructure, as well as the loss of base caused by the removal of the Lockheed Martin Hanford Company (LMHC) contract. The overall PHMC project impact of these actions was approximately five million dollars. Implementation of approved baseline changes associated with these actions was critical to providing accurate performance data in support of fiscal year spend forecasts, and performance incentives.

Integrated Priority List (IPL) Activities — The Integrated Priority List (IPL) module continues to be upgraded to provide additional functionality for the users and owners of the system. Modifications are targeted to produce additional report and sort capabilities, and align the system to better support the development of the FY 2003 budget request. System modification requirements have been developed to allow the prioritization of the units of analysis (UAs) to be more efficient, and extract selectable report crosscuts that will more fully meet future requests.

IPARS/HANDI/PERF Systems Documentation - In response to SP\&I's request, Lockheed Martin System Integration (LMSI) completed and delivered system design documentation for HANDI, PERF (the performance module), and three of the five Integrated Planning and Reporting System (IPARS) modules (Project Baseline Summary [PBS], Central Milestone Module [CMM], and the Project Execution Reporting Module [PERM]). This documentation gives a thorough reference of each application's use and function, provides a 
baseline description for future modifications, and satisfies the requirement of HNF-PRO-2778, IRM Application Software System Life Cycle Standards.

SAS Move to DOE-HQ Security Office - The Safeguard and Security (SAS) move to the DOE-HQ Security Office (SO) is continuing without official resolution as to whether the budget will be controlled by DOE-HQ Environmental Management (EM) or the SO. SP\&I assisted with the preparation and review of nine draft Field Work Proposals (requesting SAS funding for FY 2002) submitted to RL by Protection Technology Hanford.

DOE-HQ Pricing Exercise Support - SP\&I provided RL and the Projects support in completing a DOE-HQ mandated pricing and project validation exercise during the latter part of May. This year's exercise differed from prior efforts in that the pricing validation and associated programmatic reviews were conducted concurrently. There were several unanticipated logistical challenges involved and as a result, SP\&I will be making recommendations to make the process more efficient.

\section{Draft Fluor Hanford "Prospectus" for Future Planning Developed -} Utilizing the Integrated Planning Accountability, and Budget System (IPABS) Project Baseline Summary (PBS) data, SP\&I has created a draft future planning document to address EM only and EM/non-EM FH work for FY 2001 and FY 2002, based on potential budget allocations. It includes several pie charts and addresses FH's FY 2001 and FY 2002 by organization. The purpose of this "prospectus" is for use as a communication tool by FH senior management to illustrate prospective Fluor Hanford's activities (by organization) depending on the budgets allocated.

Performance Management Meetings - Three performance management meetings were scheduled for May to address "The River," "The Central Plateau," and "The FFTF" respectively. All were cancelled as requested due to schedule conflicts. However, the data materials prepared for each of these meetings were distributed to all attendees as planned. June's performance management meetings are planned as scheduled. [Editor's Update: Notification has been received that the meeting addressing "The Central Plateau," scheduled for June 29, 2000, will be cancelled, again due to schedule conflicts. The associated data materials will be prepared nonetheless, and distributed as usual.]

Business Management Oversight Process (BMOP) Status - SP\&I issued a call letter to the FH functional managers on May 8, 2000, requesting they identify documentation that addresses and demonstrates fulfillment of the BMOP criteria. To date, one functional area (Information Management) has met this request. Meetings with FH BMOP points of contact to address and clarify the requirements of the call letter are to be scheduled for June.

\section{SYSTEMS ENGINEERING AND INTEGRATION (SEI)}

Technical Baseline Products - Systems Engineering and Integration is supporting in the development of the Hanford Outcome Plan. Development activities include a situation analysis and providing current baseline data from the HSTD. 
SE\&I continue to support in the Schedule Options Study. SE\&I is supporting the effort to integrate the 100 Area strategy, the 300 Area strategy, base operations analysis, infrastructure strategy and the 200 Area strategy.

Management Systems Solutions - FH Systems Engineering and Integration is supporting the Requirements Initiative Integration Team. Interviews have been held with three functional areas (Project Controls, Training and Performance Assurance) and with the Nuclear Material Stabilization Project. Several potential areas for savings were identified and will be analyzed further during the next few months.

SEAI Infrastructure - Significant efforts associated with the startup of the new software platform [System Level Automation Tool for Engineers (SLATE)] for the Integrated Requirements Management System and the HSTD continued this month. Activities include attendance at SLATE comprehensive training, development of a HSTD test database with functional hierarchy, physical architecture, PBS and allocation of functions to PBS. Staff is working with SLATE consultants to resolve migration issues.

\section{Environmental Complance Program (ECP)}

RCRA Permit Revision and Implementation - The Environmental Compliance Program (ECP) continued coordination and support for preparation of an Appeal of the Modification E proposed Permit modifications. An updated briefing on status and path forward was prepared for senior management. In addition, Environmental Compliance coordinated sitewide input for the RCRA Permit Class 1 modifications for the quarter ending July 10, 2000 which was provided for the finalized modification package for the 14-day DOE/Contractor review.

Ecology approval to remove Dangerous Waste Training Plans (DWTP) was obtained from the RCRA Part B Permit Application. A Training Outline was put in it's place.

Air Compliance - ECP functioned as the Point-of-Contact for FH with the Washington State Department of Health's (WDOH) Olympia and Richland offices, regarding the Washington State Radioactive Air Emissions Program. Assistance in communications with WDOH and facilities/projects including PFP, WSCF Laboratory, and T Plant continued regarding compliance questions, strategies, and permitting associated with radioactive air emission compliance.

Also, work continued to proceed with the Lead Action Coordinator (LAC) for the Environmental COE, addressing the compliance orders associated with the 244-AR Vault Notice of Violation issued to ORP on March 15. The function of LAC is to determine how the compliance orders could potentially impact $\mathrm{FH}$ facilities.

The Environmental Compliance Program assisted PFP with regulatory analysis and arrangement of an immediate meeting with WDOH to document allowance of immediate preliminary work associated with the Pipe-n-Go process for $\mathrm{Pu}$ material repackaging. These actions were necessary to avoid work schedule impacts associated with the repackaging.

Regulatory analysis/review for Spent Nuclear Fuel Project was provided for the clean air compliance strategy regarding the heating, ventilation and air conditioning (HVAC) system at 
the Canister Storage Building. Also provided was review/revision support to FH Project Support \& Occurrence Reporting regarding the WDOH notification requirements specified in HNF-PRO453, Spill and Release Reporting.

Coordination for contractor participation in Ecology's Air technical assistance program was provided. This action was conducted at the request of the DOE. The Environmental Compliance Program also coordinated contractor input to and attendance at a New Source Review - Clean Air Act workshop, sponsored by the Washington State Department of Ecology on May 25, 2000.

\section{Inspections/Assessments}

The Environmental Compliance Program coordinated/supported regulatory agency inspections including follow-up information for:

- WDOH Inspection /Tour of T-Plant review of K-Basin Sludge work

- WDOH EPA Level II inspection of the 296-B-1 Stack at B-Plant

- Ecology RCRA Inspection of 340 and 331 Facility

- Ecology RCRA Inspection of WRAP

Completed the following internal environmental assessment activities:

- Performed Compliance Assessment of PFP

- Completed and issued Chemical Management Program assessment report for WRAP.

- Completed scheduled 600 Area Inspections (Rail Spills)

- Performed required RCRA Permit annual Inspection of 200 East Area.

Crosscutting Compliance/lssue - ECP coordinated and performed review of changes to WAC 173-303, Dangerous Waste Regulations to determine Hanford Site impacts. A letter was transmitted concerning a recommended change to the Hanford Emergency Management Plan, DOE/RL-94-02 concerning criteria for "implementation of the contingency plan."

ECP supported the resolution of numerous "walk-in" compliance issue requests for the Nuclear Material Stabilization Project, River Corridor Project, and Site Infrastructure Project.

A Compliance Review of WESF Ecology Inspection closeout and a review of the Notice-ofCompliance letter were conducted.

Spill and Release Reporting - The Environmental Compliance Program provided reporting coordination for sixteen (16) non-reportable releases of a hazardous substance and /or a petroleum product released to the environment. All of these releases were cleaned up and disposed of per state and federal requirements. There were no reportable events, with a release to the environment and one (1) reportable code non-compliance events that were reported directly to the off site regulatory agency(s) by the FH Environmental Spill Point Of Contact.

Chemical Management- Progress continued on developing subcontractor requirements for chemicals used onsite, defining the Chemical receiving/distribution process, development of 
quality level inspection requirements for P-Card Purchase of chemicals, creation of a Chemical Management Web Page, and uploading of existing facility chemical inventories into the Chemical Management System.

An effort is underway to remove all excess chemicals from the Waste Management Project facilities and applying this process to the other Fluor Hanford facilities.

NEPA - Reviews were accomplished on two draft DOE National Environmental Policy Act (NEPA) related guidance documents: Guidance on "Incorporating Environmental Justice Considerations into the Department of Energy's National Environmental Policy Act Process;" and "Analyzing Accidents in DOE NEPA Documents."

Management and Administrative Support - The Environment \& Regulation Web site continues to expand. Updates of meeting agendas and minutes continue each month. Future items are slowly being developed and posted on the site.

Preparation began of a new Inspection Protocol Document to address all regulatory agency inspections at the Hanford Site.

ECP staff attended the Quality Assurance Task Force for the Pacific Northwest meeting hosted by the State of Washington Department of Health in Richland on May 23. Topics included laboratory proficiency testing/QA programs, environmental surveillance, tritium in Hanford milk samples, and 1999 and 2000 sample analysis inter-comparisons. The results of last year's annual inter-comparison program were provided. This includes all the laboratories (usually 9-11) that analyze the environmental samples.

A workshop was held on May 25, 2000 to restructure the 2001 ECP Cost Accounts and Activities. New Basis of Estimates (BOE) documents will be prepared to reflect the new structure which provide the basis for the FY-2001 ECP MYWP.

\section{Public Safety and Resource Protection (PSRP)}

The PS\&RPP Projects were all conducted in accordance with the scope, milestones, and budget defined in the FY 2000 PS\&RPP (PBS \# RL-OT01) Multi-Year Work Plan during May.

\section{ACCOMPLISHMENTS}

\section{Site Planning and Integration (SP\&I)}

- The deliverable, Second Quarter PHMC Status report was completed on May 10, 2000.

- The deliverable, Monthly EMPR was delivered to RL on June 14, 2000

- The deliverable, Support the IRB Corporate Forum Presentation was completed on May 22, 2000.

- The deliverable, Mid Year 1.8.2.1. Progress Status with RL was held on May 18, 2000.

\section{System Engineering and Integration (SEI)}

None to report. 


\section{Environmental Compliance Program (ECP)}

- Milestone ECP-00-307, "Submit DOE Order 435.1 Implementation Plan", was completed on schedule on May 15, 2000.

- Milestone ECP-00-410, "The Portable/Temporary Radioactive Air Emissions Units (PTRAEU) and HEPA Vacuum Units (HVU) Annual Report", was completed and submitted on June 14, 2000. Transmittal of this report by RL to the Washington Department of Health will satisfy requirements contained in the approved radioactive air notices of construction that cover PTRAEU and HVU activities on the Hanford site. This milestone was completed one day early.

- Milestone ECP-00-803, "Annual Radionuclide Air Emissions Report" was issued on schedule on June 15, 2000.

- Hanford Site prime contractors completed certification of the Air Operating Permit Application Supplement on June 15, 2000. Fluor Hanford certified for information pertaining to its air emission activities, as well as for its consolidation of air emission information for the other Hanford primes. RL is planning to submit the RL certified supplement to the State of Washington, Department of Ecology (Ecology) by the end of June.

\section{Public Safety and Resource Protection (PSRP)}

- Surface Environmental Surveillance Project (SESP) staff participated in and helped stage the Washington Department of Health Quality Assurance Task Force (QATF) Meeting for Spring 2000 held on May 10 in Richland. SESP staff made two presentations: 1) Elevated Tritium in Downwind Cow's Milk, and 2) Review of 1999 QATF Intercomparison.

- PS\&RPP staff were recognized for their efforts during the elk relocation conducted in March 2000, with Outstanding Performance Awards. The PS\&RPP provided radiological and sample collection support, resources to support the helicopter round-up activity, and Site institutional knowledge relative to elk behavior during the cooperative relocation effort that included the U.S. Fish and Wildlife Service, Washington Department of Fish and Wildlife, and U.S. Department of Energy. Recognized were Brett Tiller, Ernest Antonio, Rhett Zufelt, and bargaining unit staff Eddie Radford, Larry Belt (retired) and Wade Sheets.

- The White Bluffs Road Survey was completed during the reporting period. This historic road, which was almost certainly an older Indian trail, is listed on the National Register of Historic Places.

- PNNL Key milestone RLOT016003, "Complete Blanket Ecological Compliance Reviews for Five Key Hanford Locations" was completed May 15, on schedule.

\section{ISMS STATUS}

Submitted deficiency evaluation closure documentation for Environmental Services ISMS SelfAssessment, completed a safety inspection of work areas, and completed an "Issue Management" self-assessment 


\section{BREAKTHROUGHS / OPPORTUNITIES FOR IMPROVEMENT}

Nothing to report at this time.

\section{ÚPCOMING ACTIVITIES}

- Milestone ECP-00-504: "Annual PCB Document Log - June." is due on June 22, 2000

- Milestone ECP-00-502: "ECRA Section 313 Toxic Chemical Release Inventory" is due on June 23, 2000

- Milestone ECP-00-413, "Second PTREAU Assessment Report to RL", is due June 30, 2000.

- Milestone ECP-00-305, "RCRA Permit Class 1 Modification Quarter 4", is due July 3, 2000.

- Milestone ECP-00-405, "Provide RL with Air/Water Permitting Schedule", is due July 5, 2000.

- Milestone ECP-00-507, "Annual LDR Report (M-26-01)", is due July 21, 2000.

- The PS\&RP Program will complete the 1999 Site Environmental Report (FO Milestone RLOT013003) in September 2000.

\section{Cost Performance (M):}

\begin{tabular}{|l|c|c|c|}
\hline & BCWP & ACWP & VARIANCE \\
\hline Mission Support 1.8 & $\$ 21.2$ & $\$ 24.6$ & $-\$ 3.3$ \\
\hline
\end{tabular}

The $\$ 3.3$ million (16 percent) unfavorable cost variance is due to several factors. Further information at the PBS level can be found in the following Cost Variance Analysis details.

\section{Schedule Performance (M):}

\begin{tabular}{|l|c|c|c|}
\hline & BCWP & BCWS & VARIANCE \\
\hline Mission Support 1.8 & $\$ 21.2$ & $\$ 25.6$ & $-\$ 4.3$ \\
\hline
\end{tabular}

The $\$ 4.4$ million (17 percent) unfavorable schedule variance is due to several factors. Further information at the PBS level can be found in the following Schedule Variance Analysis details. 
FY 2000 COSt/SCHEDUle PerformanCe - All Fund TYPes Cumulative to Date Status - (\$000)

By PBs

\begin{tabular}{llllllll}
\hline BCWS BCWP ACWP SV & $\%$ & CV & $\%$ & PEM FYSF EAC
\end{tabular}

PBS OT04

RL Directed

S 9,681 \& 6,387 \& 9,690 \& $(3,294)-34.0 \%$ \& $(3,303)-51.72 \%$ \& 22,053 S 22,053 \$ 22,053

WBS I.8.I Support

PBS OT01 Mission

WBS 1.8 .2

Support MYPs

Total

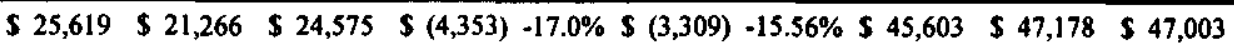

\section{Cost/SChedule Performance Indices (MONTHLY AND FYTD)}

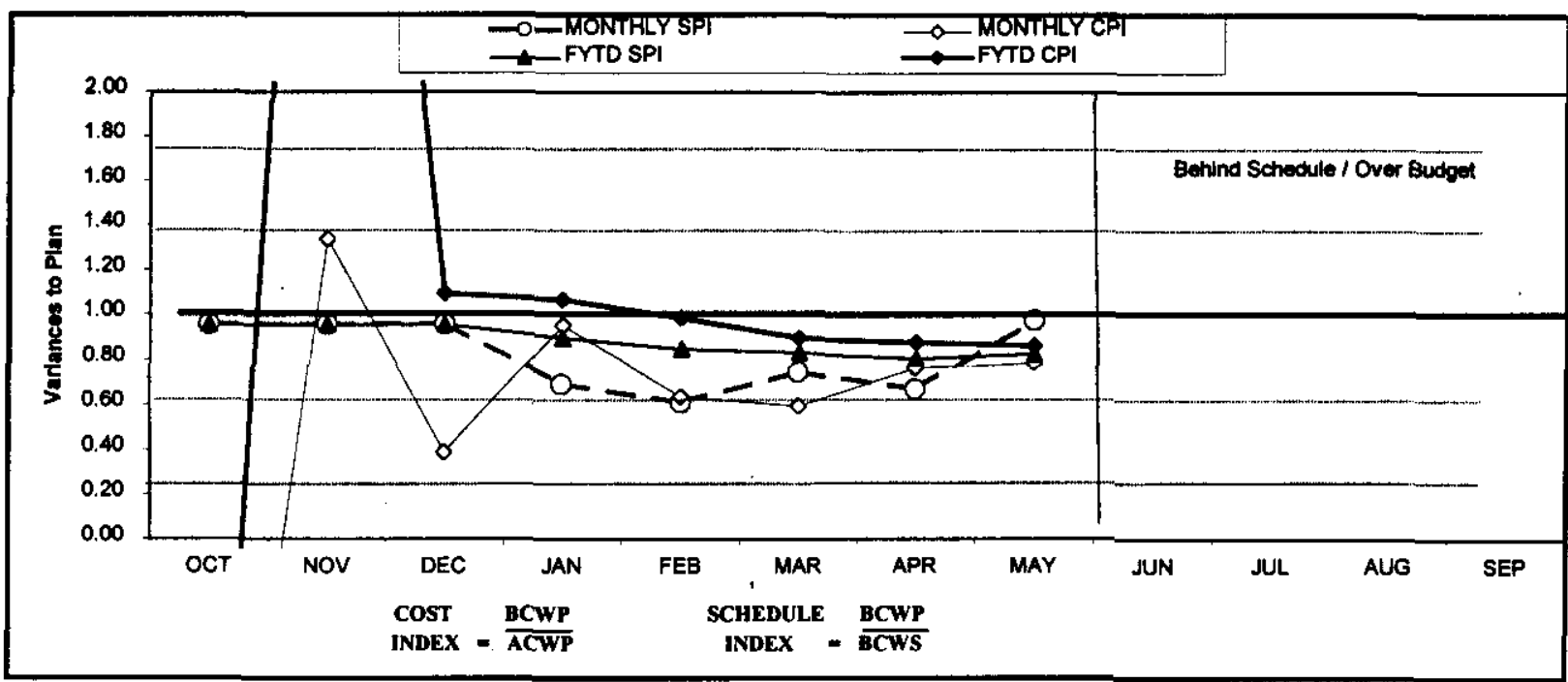

\begin{tabular}{|c|c|c|c|c|c|c|c|c|c|c|c|c|}
\hline FY 2UW & OrT & NOV & DEC & JAN & FE: & MAR & APR & MAY & JUN & JUL & AUG & SEP \\
\hline MONTHLYSPI & $0 \%$ & $0 . \%$ & 0.96 & 0.69 & 0.61 & 0.74 & 0.67 & 0.98 & & & & \\
\hline MONIHLYCPI & -2.27 & T.34 & 0.39 & 0.95 & 0.63 & 0.39 & 0.76 & 0.79 & & & & \\
\hline FYIDSPI & $0 . \%$ & 0.96 & $0 . \%$ & 0.90 & 0.85 & 0.83 & 0.81 & 0.83 & & & & \\
\hline FYIDCPI & -2.27 & 5,83 & 1.09 & T.07 & 0.98 & 0.90 & 0.88 & 0.87 & & & & \\
\hline MONTHLYBCWS & $\mathbf{3 3 , 4 9 3}$ & 33,716 & 33,221 & 33,080 & 32,758 & 33,180 & 33,009 & 53,I81 & $\mathbf{5 2 , 7 8 2}$ & \$S,534 & 35,832 & $\$ 5,836$ \\
\hline MONTHIYYCWP & 33,359 & 53,552 & 33,087 & 52,126 & $\$ 1,666$ & 52,366 & 32,008 & 53,121 & & & & \\
\hline MONTHLY ACWP & $(31,473)$ & $\mathbf{5 2 , 6 5 5}$ & 37,957 & 32,232 & 32,630 & 33,995 & $\mathbf{3 2 , 6 5 8}$ & 35,961 & & & & \\
\hline FYTDECWS & 33,493 & 57,209 & 510,430 & ST3,STO & \$16,248 & \$19,428 & $\mathbf{3 2 2 , 4 3 7}$ & 525,619 & 528,400 & 533,934 & 359,766 & 45,603 \\
\hline FYTDBCWP & $\$ 3,339$ & 56,891 & 39,978 & 312,104 & $\$ 13,770$ & 516,136 & 318,145 & 521,266 & & & & \\
\hline FYIDACWP & (S1,473) & 31,182 & 39,119 & \$11,351 & \$13,981 & 317,976 & 320,613 & 524,575 & & & & \\
\hline
\end{tabular}

\section{COST VARIANCE ANALYSIS: $(-\$ 3.3 \mathrm{M})$}

\section{WBS/PBS}

\subsection{1/OT04}

Description/Cause: The $\$ 3.3$ million (52 percent) unfavorable cost variance is due to payments in lieu of taxes to Benton, Franklin and Grant Counties are not due to be paid until September / October time frame.

Impact: No impact. 
Corrective Action: No corrective action required.

\subsection{2/OT01}

Mission Support

Description/Cause: There is no cost variance to report.

Impact: 'No impact.

Corrective Action: No corrective action required.

\section{SCHEdUle VARIANCE ANALYSIS: (-\$4.4 M)}

\subsection{1/OT04 \\ RL Directed Support}

Description/Cause: The $\$ 3.3$ million (34 percent) unfavorable schedule variance is due to payments in lieu of taxes to Benton, Franklin and Grant Counties are not due to be paid until September/October time frame.

Impact: No impact.

Corrective Action: No corrective action required.

\subsection{2/OT01 Mission Support}

Description/Cause: The $\$ 1.1$ million (7 percent) unfavorable schedule variance is within acceptable reporting thresholds.

Impact: No impact.

Corrective Action: No corrective action required.

\section{Technical Issues}

\section{ISSUES}

Issue: Baseline Updating Guidance (BUG) has not yet been received from Mission Planning Division. There are many outstanding issues still to be reconciled before $\mathrm{FH}$ can proceed with providing Multi-Year Work Plan (MYWP) guidance to the FH Projects.

Impact: As guidance is delayed, Projects and support functions will be forced into an overtime situation and production of a less than desired product for the FY 2001 site baseline.

Corrective Action/Status: A draft BUG was issued on May 26, 2000; however SP\&I has been notified that a re-write of the BUG document has occurred. As of this writing, it is anticipated that $\mathrm{FH}$ will receive final guidance by June 15,2000 .

Issue: Update of project baselines for the impacts of company overhead rate and organizational changes associated with the PHMC restructure (including the ORP split) have not been made pending project submission and RL approval of Baseline Change Requests (BCRs). The overall PHMC project impact of these actions is projected at $\$ 5 \mathrm{M}$. Projects are not implementing subsequently approved baseline changes pending implementation of restructured budget rate libraries, resulting in outdated performance baselines. Implementation of approved baseline changes associated with these actions is critical to providing accurate performance data in support of fiscal year spend forecasts, and performance incentives. 
Impact: None

Corrective Action/Status: Updates of project baselines for the impacts of company overhead rate and organizational changes associated with the PHMC restructure, as well as the loss of base caused by the removal of the $\mathrm{LMHC}$ contract, were implemented into project cost baselines in May, based upon RL approval of Baseline Change Requests (BCRs). The overall PHMC project impact of these actions was approximately $\$ 5 \mathrm{M}$. Implementation of approved baseline changes associated with these actions was critical to providing accurate performance data in support of fiscal year spend forecasts, and performance incentives.

\section{DOE/Regulator/External Issues}

Issue: The Washington Department of Health issued a draft letter dated May 17, 2000 in which clarifications were made specifically to potential locations for the Maximum Exposed Individual (MEI). Now excluded from consideration are public highways and the Columbia River shoreline. Energy Northwest's WNP-2, LIGO, and publicly accessible facilities in the 300 Area remain as valid locations. Unmentioned in the letter are needed details on MEI dose modeling parameters such as length of occupancy (e.g., 2,000 hours versus 8,760 hours a year) and sources of food stuffs consumed. Those parameters have a significant impact on calculated doses.

Impact: The undefined parameters have a significant impact on calculated doses for the MEI.

Corrective Action/Status: Environmental Services staff continue to negotiate with WDOH staff to clarify their definition of the parameters for MEI determination. 
Baseline Change Requests Currently in Process

(\$000)

\begin{tabular}{|c|c|c|c|c|c|c|c|c|c|}
\hline $\begin{array}{l}\text { PRONECT } \\
\text { CHANGE } \\
\text { NUMRTR }\end{array}$ & $\begin{array}{c}\text { DATE } \\
\text { ORIGIN }\end{array}$ & BCRTILE & $\begin{array}{c}\text { FYO0 } \\
\text { OOST } \\
\text { IMPACT } \\
\text { SON0 }\end{array}$ & SCH & TECH & $\begin{array}{c}\text { DATE TO } \\
\text { OCB }\end{array}$ & $\begin{array}{c}\text { CCB } \\
\text { APR'VD }\end{array}$ & Re APRVD & $\begin{array}{c}\text { CURRENT } \\
\text { STATUS }\end{array}$ \\
\hline SPI-2000-001 & $107 / 99$ & $\begin{array}{c}\text { Addition of Paths to Closure Range } \\
\text { Estimate }\end{array}$ & $\$ 67$ & & & & & & Approved \\
\hline SPI-2000-002 & $10 / 22 / 99$ & FY 1999 Carryover Soope & $\$ 248$ & $\mathbf{X}$ & $\mathrm{X}$ & $2 / 3 / 00$ & $2 / 3 / 00$ & & In Progress \\
\hline SPI-2000-003 & $11 / 5 / 99$ & \begin{tabular}{|l} 
Baseline Modifications to Support Fiscal \\
Year 2000 Mutti-Year Work Plan Update
\end{tabular} & $(\$ 923)$ & & & $3 / 23 / 00$ & $3 / 23 / 00$ & $5 / 14 / 00$ & Approved \\
\hline SPI-2000-006 & $2 / 17 / 00$ & $\begin{array}{l}\text { Modeling Tool \& IPL Module Scope } \\
\text { Additions FY } 2000\end{array}$ & $\$ 117$ & $\mathrm{X}$ & $\mathrm{X}$ & $2 / 17 / 00$ & $2 / 17 / 00$ & $5 / 4 / 00$ & Approved \\
\hline SPI-2000-007 & $4 / 28 / 00$ & $\begin{array}{l}\text { 10\% Rectuction to FY } 20001.8 .2 .1 \\
\text { Baseline }\end{array}$ & $\$ 675$ & & $\mathrm{x}$ & & & & Draft \\
\hline PSR-2000-001 & $1 / 25 / 00$ & $\begin{array}{l}\text { Alignment of Budget/Scope to Funding } \\
\text { Allocation and Incorporation of FY } 1999 \\
\text { Carry Over } \\
\text { Holding }\end{array}$ & $\$ 193$ & $\mathrm{x}$ & & & & $5 / 4 / 00$ & Approved \\
\hline $\begin{array}{l}\text { SSE-2000-001 } \\
\text { SSE-2000-002 }\end{array}$ & $\begin{array}{r}10 / 699 \\
10 / 18 / 99\end{array}$ & $\begin{array}{l}\text { FY } 2000 \text { Bridge Change Request } \\
\text { FY } 99 \text { Carryover }\end{array}$ & (\$88) & & & $11 / 1099$ & $11 / 10999$ & $1 / 26 / 00$ & $\begin{array}{l}\text { Approved } \\
\text { RWOA-F }\end{array}$ \\
\hline SSE-2000-003 & $1 / 31 / 00$ & Repricing Impacts to Baseline & & & & & & & Draft \\
\hline ECP-2000-001 & $11 / 15 / 00$ & $\begin{array}{l}\text { Correctional/Alignment of ECP } \\
\text { Milestones }\end{array}$ & & & & $11 / 30 / 99$ & $11 / 3099$ & $1 / 26 / 00$ & Approved \\
\hline ECP-2000-002 & $12 / 7 / 99$ & $\begin{array}{l}\text { Remove Project W-420 from } \\
\text { Environmental Compliance Program }\end{array}$ & $(\$ 1,380)$ & & & $1 / 5 / 00$ & $1 / 6 / 00$ & $2 / 11 / 00$ & Approved \\
\hline ECP-2000-003 & $12 / 15 / 00$ & \begin{tabular}{|l|} 
Utilization of ECP FY - 99 Uncosted \\
Carryover
\end{tabular} & $\$ 449$ & & & & & & Draft \\
\hline ECP-2000-004 & $2 / 15 / 00$ & $\begin{array}{l}\text { Adjust Baseline to Fina' FY } 2000 \text { Funding } \\
\text { Allocations and Change ECP-00-410 } \\
\text { Milestone Date }\end{array}$ & $\$ 161$ & & & $4 / 7 / 00$ & $4 / 7 / 00$ & $5 / 10 / 00$ & Approved \\
\hline & $4 / 18 / 00$ & $\begin{array}{l}\text { Change Due Date for ECP Milestone } \\
\text { ECP-00-704 }\end{array}$ & & & & $5 / 4 / 00$ & $5 / 4 / 00$ & $5 / 25 / 00$ & Approved \\
\hline ECP-2000-006 & $5 / 2 / 00$ & Rebuild Automated Bar Coding of Air & $\$ 193$ & $\mathrm{X}$ & & & & & Draft \\
\hline ECP-2000-007 & $5 / 15 / 00$ & $\begin{array}{l}\text { Change Level and Type of Environmental } \\
\text { Compliance Program(ECP) Milestones }\end{array}$ & & & & $5 / 31 / 00$ & & & In Progress \\
\hline \multicolumn{10}{|c|}{ ADVANCE WORK AUTHORZZATIONS } \\
\hline & & Nothing to report. & & & & & & & \\
\hline
\end{tabular}




\section{Milestone ACHIEVEMENT}

\begin{tabular}{|c|c|c|c|c|c|c|c|c|}
\hline \multirow[b]{2}{*}{ MILESTONE TYPE } & \multicolumn{4}{|c|}{ FISCAL YEAR-TO-DATE } & \multicolumn{3}{|c|}{ REMAINING SCHEDULED } & \multirow[b]{2}{*}{$\begin{array}{c}\text { TOTAL } \\
\text { FY } \\
2000\end{array}$} \\
\hline & $\begin{array}{c}\text { Completed } \\
\text { Early }\end{array}$ & $\begin{array}{c}\text { Completed } \\
\text { On } \\
\text { Schedule }\end{array}$ & $\begin{array}{c}\text { Completed } \\
\text { Late }\end{array}$ & Overdue & $\begin{array}{c}\text { Forecast } \\
\text { Early }\end{array}$ & $\begin{array}{c}\text { Forecast } \\
\text { On } \\
\text { Schedule }\end{array}$ & $\begin{array}{c}\text { Forecast } \\
\text { Late }\end{array}$ & \\
\hline Enforceablo Agreement & 13 & 2 & 0 & 1 & 0 & 10 & of & 26 \\
\hline DOE-HQ & 0 & of & 0 & 0 & 0 & 2 & 0 & 2 \\
\hline $\mathbf{R L}$ & 5 & 5 & 3 & 0 & 0 & 73 & of & 26 \\
\hline Total Project & 18 & 7 & 3 & 1 & $\overline{0}$ & 25 & 0 & 54 \\
\hline
\end{tabular}

\begin{tabular}{|c|c|c|c|}
\hline \multicolumn{4}{|c|}{ Tri-Party / greement / EA Milestones } \\
\hline Number & $\begin{array}{ll}\text { Milestone Title } \\
\end{array}$ & Baseline Date & $\begin{array}{c}\text { Actual } \\
\text { Completion } \\
\text { Date/Status }\end{array}$ \\
\hline ECP-00-302 & $\begin{array}{l}\text { RCRA Permit Class } 1 \text { Mod Notification Quarter } 1 \\
\text { (For Year 2000-2046) }\end{array}$ & $10 / 01 / 1999$ & $09 / 30 / 1999$ \\
\hline ECP-00-702 & $\begin{array}{l}\text { RCRA RPTS/DOCS Closure/Post Closure Cost Est. } \\
\text { to RL }\end{array}$ & $10 / 22 / 1999$ & $10 / 06 / 1999$ \\
\hline ECP-00-901 & Issue Quarterly NESHAP Status RPT to RL for EPA & $10 / 22 / 1999$ & $10 / 20 / 1999$ \\
\hline EPC-00-306 & $\begin{array}{l}\text { Annual Asbestos Notification of Intent (For Year } \\
\qquad \begin{array}{c}2000-2046) \\
\end{array}\end{array}$ & $12 / 31 / 1999$ & $12 / 14 / 1998$ \\
\hline ECP-00-303 & $\begin{array}{l}\text { RCRA Permit Class } 1 \text { Mod Notification Quarter } 2 \\
\text { (For FY 2000-2046) }\end{array}$ & $01 / 01 / 2000$ & $12 / 16 / 1999$ \\
\hline ECP-00-902 & Issue Quarterly NESHAP Status RPT to RL for EPA & $01 / 28 / 2000$ & $01 / 17 / 1999$ \\
\hline ECP-00-410 & $\begin{array}{l}\text { Annual PTRAEU Report to DOE-RL (For FY 2000- } \\
\text { 2046) }\end{array}$ & $02 / 01 / 2000$ & Overdue \\
\hline ECP-00-701 & Annual Noncompliance Report to RL & $02 / 17 / 2000$ & $02 / 09 / 2000$ \\
\hline ECP-00-503 & $\begin{array}{l}1999 \text { Hanford Site Annual Dangerous Waste Report } \\
\text { (FY 2000-2046) }\end{array}$ & $02 / 22 / 2000$ & $02 / 22 / 2000$ \\
\hline ECP-00-501 & Tier II Emergency \& Hazardous Chemical Inventory & $02 / 23 / 2000$ & $02 / 23 / 2000$ \\
\hline ECP-00-003 & $\begin{array}{c}\text { Biennial Assess. Of Info. \& Data Access Needs } \\
\text { EPA/ECO }(2000-2046)\end{array}$ & $03 / 31 / 2000$ & $03 / 06 / 2000$ \\
\hline ECP-00-801 & Transmit EIS/ODIS Data to INEEL (FY 2000-2046) & $04 / 01 / 2000$ & $04 / 01 / 2000$ \\
\hline ECP-00-802 & $\begin{array}{l}\text { Issue Annual Non-Radioactive Airborne Emissions } \\
\text { Report (FY 2000-2046) }\end{array}$ & $04 / 01 / 2000$ & $04 / 01 / 2000$ \\
\hline ECP-00-304 & $\begin{array}{l}\text { RCRA Permit Class I Mod Notification Quarter } 3 \\
\text { (For FY 2000-2046) }\end{array}$ & $04 / 02 / 2000$ & $04 / 02 / 2000$ \\
\hline ECP-00-904 & $\begin{array}{l}\text { Issue Quarterly NESHAP Status Report To RL for } \\
\text { EPA }\end{array}$ & $04 / 21 / 2000$ & $04 / 21 / 2000$ \\
\hline ECP-00-803 & $\begin{array}{l}\text { Issue Annual Radionuclide Air Emissions Report } \\
\text { (For FY 2000-2046) }\end{array}$ & $06 / 15 / 2000$ & $06 / 14 / 2000$ \\
\hline ECP-00-502 & $\begin{array}{l}\text { EPCRA Section 313 Toxic Chemical Release } \\
\text { Inventory }\end{array}$ & $06 / 23 / 2000$ & \\
\hline ECP-00-504 & Annual PCB Document $\log -$ June & $06 / 23 / 2000$ & \\
\hline ECP-00-305 & $\begin{array}{l}\text { RCRA Permit Class I Mod Notification Quarter } 4 \\
\text { (For FY 2000-2046) }\end{array}$ & $07 / 02 / 2000$ & \\
\hline ЕСР-00-505 & PCB Annual Report - July & $07 / 07 / 2000$ & \\
\hline ECP-00-507 & Annual LDR Report (M-26-01) & $07 / 21 / 2000$ & \\
\hline
\end{tabular}




\begin{tabular}{|c|c|c|c|}
\hline ECP-00-906 & Issue Quarterly NESHAP Status Report to RL for & $07 / 28 / 2000$ & \\
EPA & $\begin{array}{c}\text { FA Pipe Mapping and Marking (For } \\
\text { FCY-00-703 2000-2046) }\end{array}$ & $09 / 21 / 2000$ & \\
\hline ECP-00-301 & $\begin{array}{c}\text { Coordinate RCRCA General Facility Inspections (For FY 2000- } \\
\text { 2046) }\end{array}$ & $09 / 30 / 2000$ & \\
\hline & DNFSB Commitments & & \\
\hline & Nothing to report. & & \\
\hline
\end{tabular}

\section{MILESTONE EXCEPTION REPORT}

\section{Number/WBS Level \\ OVerdue - 1}

Milestone Title

Baseline

Date

Forecast

ECP-2000-410 EA

1.8.2.3.4
Annual Portable/Temporary Radioactive $\quad 02 / 01 / 00 \quad 06 / 15 / 00$

Air Emissions Units (PTRAEU) and HEPA

Vacuum (HVU) Report to RL

Air and Water Services

Cause: The February 1, 2000 milestone due date does not reflect the due date specified in the Technical Workscope Description for this activity. The June 15, 2000 due date for this milestone in the Technical Workscope Description is the correct due date.

Impact: No impact.

Corrective Action: This milestone was completed on June 14, 2000.

\section{Performance Objectives}

Nothing to report at this time.

\section{KEY INTEGRATION ACTIVITIES}

The Environmental Compliance Program performed review and recommendations for PFP of Facility Evaluation Board (FEB) environmental findings.

Specific components of the PS\&RP Program are identified as a critical core project within the Groundwater/Vadose Zone Integration Project. As such, key activities relevant to both programs were integrated into FY 2001 detailed work plans as appropriate. 


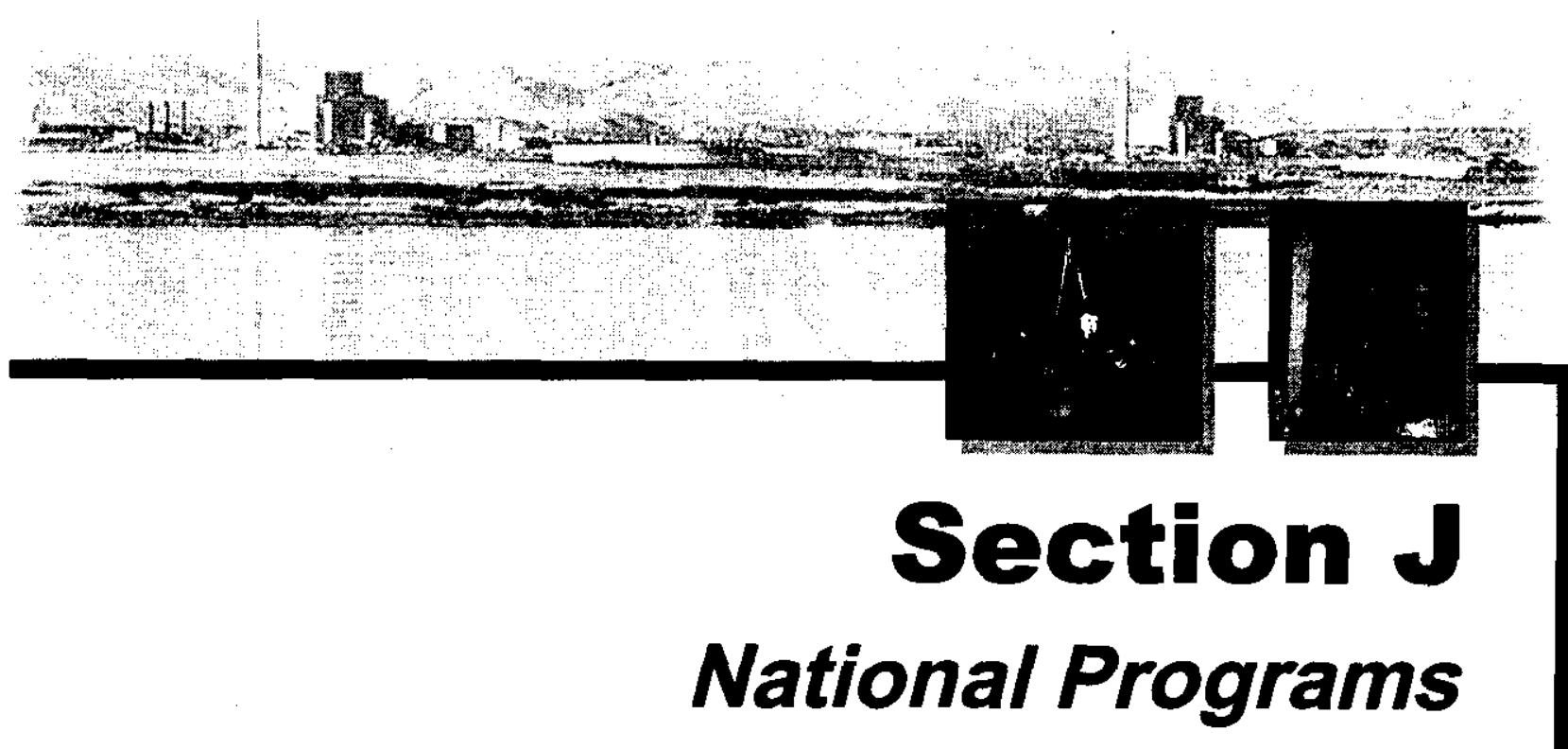




\section{Introduction to National Programs}

DOE EM is responsible for a variety of National Programs. DOE-HQ typically provides operations policy and programmatic guidance to one or more field office that serve as lead for individual programs. FH currently supports the following National Programs: Transportation and Packaging (PBS OT02) and Pollution Prevention and Waste Minimization (PBS WM07).

Transportation and Packaging provides full-service transportation and packaging capabilities. Packaging services for radioactive and hazardous cargo is provided, including regulatory safetybasis documentation, certification, and licensing. Packaging plans and logistical studies for major shipping campaigns are also provided, as well as approved training courses in transportation safety and waste management. Transportation and traffic logistics management, engineering and operational support to offsite customers, carrier selection and evaluation, automated transportation management systems used by the U.S. Department of Energy (DOE) complex and commercial vendors, and international transport of hazardous and radioactive packages are other services provided.

Pollution Prevention and Waste Minimization (P2/WMin) coordinates the development and implementation of a Hanford Site P2/WMin Program to comply with Federal, state, and DOE directives. The program's purpose is to achieve Site objectives through effective and efficient methodologies tailored to generator activities and operations.

\section{ACCOMPLISHMENTS}

- $\quad$ Preparations have been initiated to prepare the "Draft Hanford Site FY 2001 Strategy for Meeting the Secretary of Energy's FY 2005 P2/WMin Goals." 


\section{FY 2000 Cost/SChedule Performance - All Fund Types Cumulative to Date Status - $(\$ 000)$}

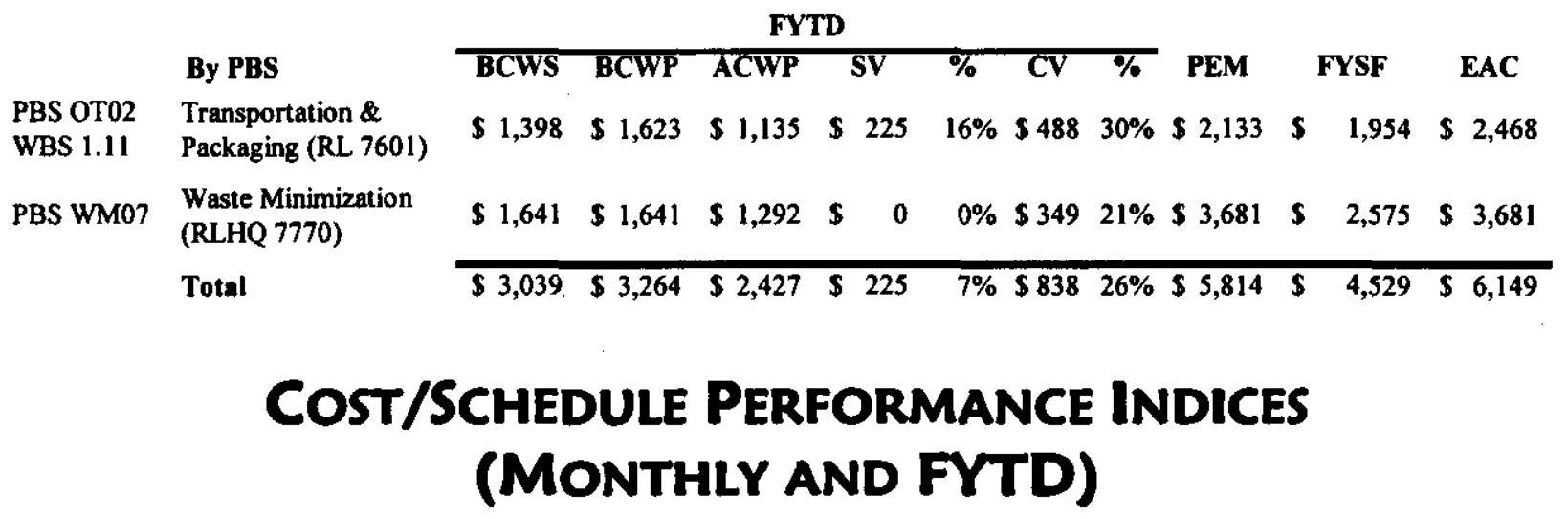

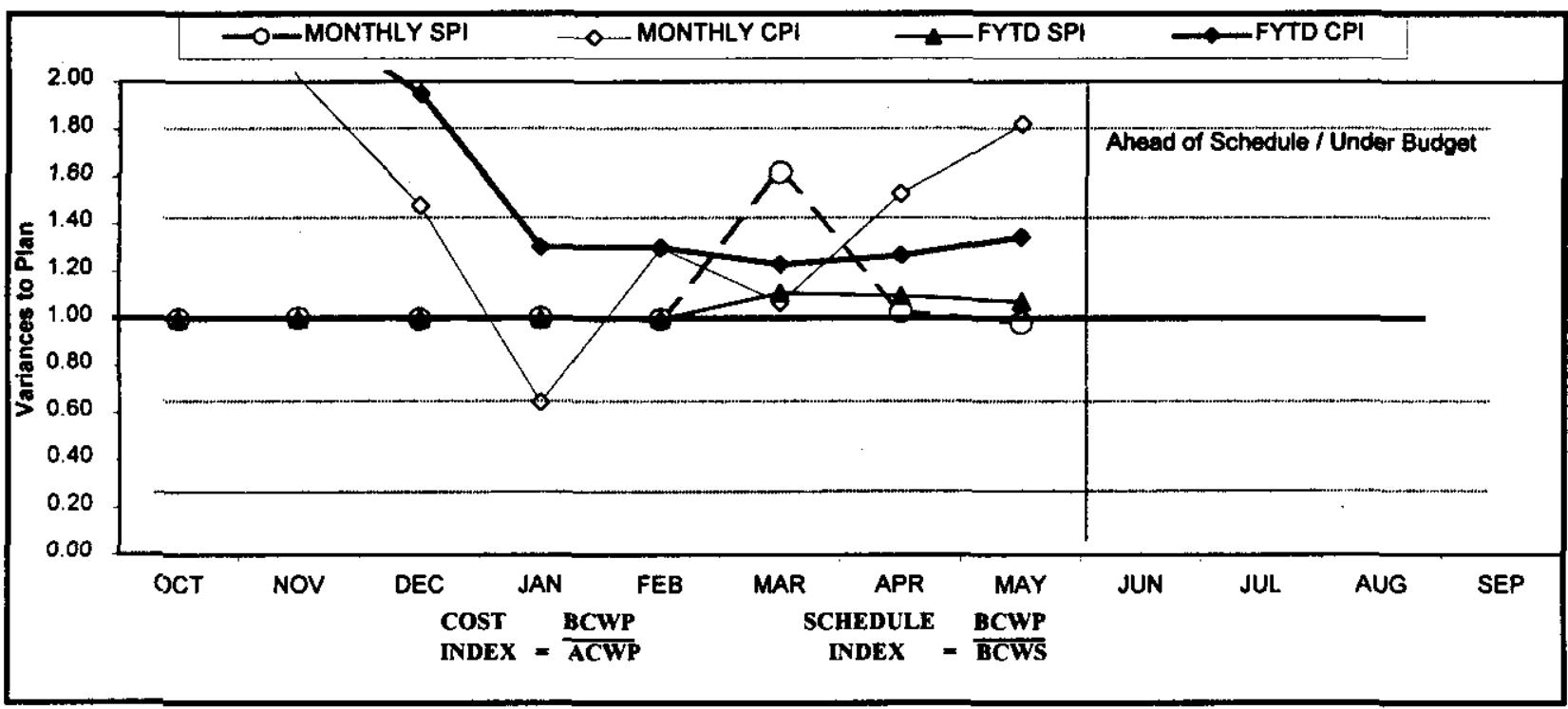

\begin{tabular}{|c|c|c|c|c|c|c|c|c|c|c|c|c|}
\hline FY 2000 & OCT & NOV & DEC & JAN & FEB & MAR & APR & MAY & JUN & JUL & AUG & SEP \\
\hline MONTHLY SPI & 1.00 & 1.00 & 1.00 & 7.00 & 1.00 & 1.62 & 1.03 & 0.98 & & & & \\
\hline MONTRILYCPT & 2.81 & 2.0 & 1.48 & 0.65 & 1.30 & 1.07 & 1.53 & 7.82 & & & & \\
\hline FYTDSPI & 7.00 & T.O & 1.00 & 7.00 & 1.00 & T.TI & 1.70 & 1.07 & & & & \\
\hline FYTDCPI & 2.81 & 2.3 & T.95 & 1.30 & 1.30 & $T .23$ & T.27 & T.35 & & & & \\
\hline MONTALYBCWS & 304 & 383 & 328 & 329 & 324 & 361 & 398 & 6ा1 & 346 & 546 & 658 & 7,025 \\
\hline MONIALY BCWP & 5305 & 384 & 328 & 330 & 324 & 385 & 409 & 601 & & & & \\
\hline MONTFILY ACWP & 5108 & 191 & 222 & 312 & 249 & 347 & 268 & 330 & & & & \\
\hline FYTDBCWS & 304 & $\$ 687$ & 1,015 & $\$ 7,345$ & 5 1,669 & 2,030 & 2,428 & 3,039 & 53,586 & $\$ 4,132$ & 54,789 & 3,814 \\
\hline FYTDBCWP & 303 & 687 & 1,015 & 7,345 & 51,669 & 2,254 & 2,663 & 3,264 & & & & \\
\hline YTIDACWP & 708 & 299 & 521 & 7,033 & 1,282 & 1,829 & 2,096 & 2,427 & & & & \\
\hline
\end{tabular}




\section{Cost VARIANCE ANalysis: $(+\$ 0.8 \mathrm{M})$}

\section{WBS/PBS $\quad$ Title}

1.11.1/OT02 Transportation and Packaging

Description and Cause: The $\$ 488 \mathrm{~K}$ ( 30 percent) favorable cost variance is due to no MCEP evaluations being done because of a major change in the MCEP. When the revision is complete, MCEP field audits will resume which will increase both travel and labor costs. Additionally, the ATMS/ETAS integration project will not be started until FY2001, at the request of the NTP customer.

Impact: None.

Corrective Action: MCEP spending curve will increase in the later half of the year.

1.11.2/WM07 Pollution Prevention/Waste Minimization

Description and Cause: The $\$ 349 \mathrm{~K}$ (21 percent) favorable cost variance is due to staffing shortfalls in first half of year.

Impact: None

Corrective Action: Under-runs will be utilized to offset funding shortfall in Fiscal Year 2001.

\section{SCHEDUle VARIANCE ANALYSIS: $(+\$ 0.2 \mathrm{M})$}

\section{$\underline{\text { WBS/PBS }} \quad \underline{\text { Title }}$}

1.11.1/OT02 Transportation and Packaging

Description and Cause: The $\$ 225 \mathrm{~K}$ ( 16 percent) favorable schedule variance is due to program efficiencies.

Impact: None.

Corrective Action: None. 


\section{Richland Operations Office Environmental Restoration \\ Environmental Management Performance Report}

\section{July 2000}

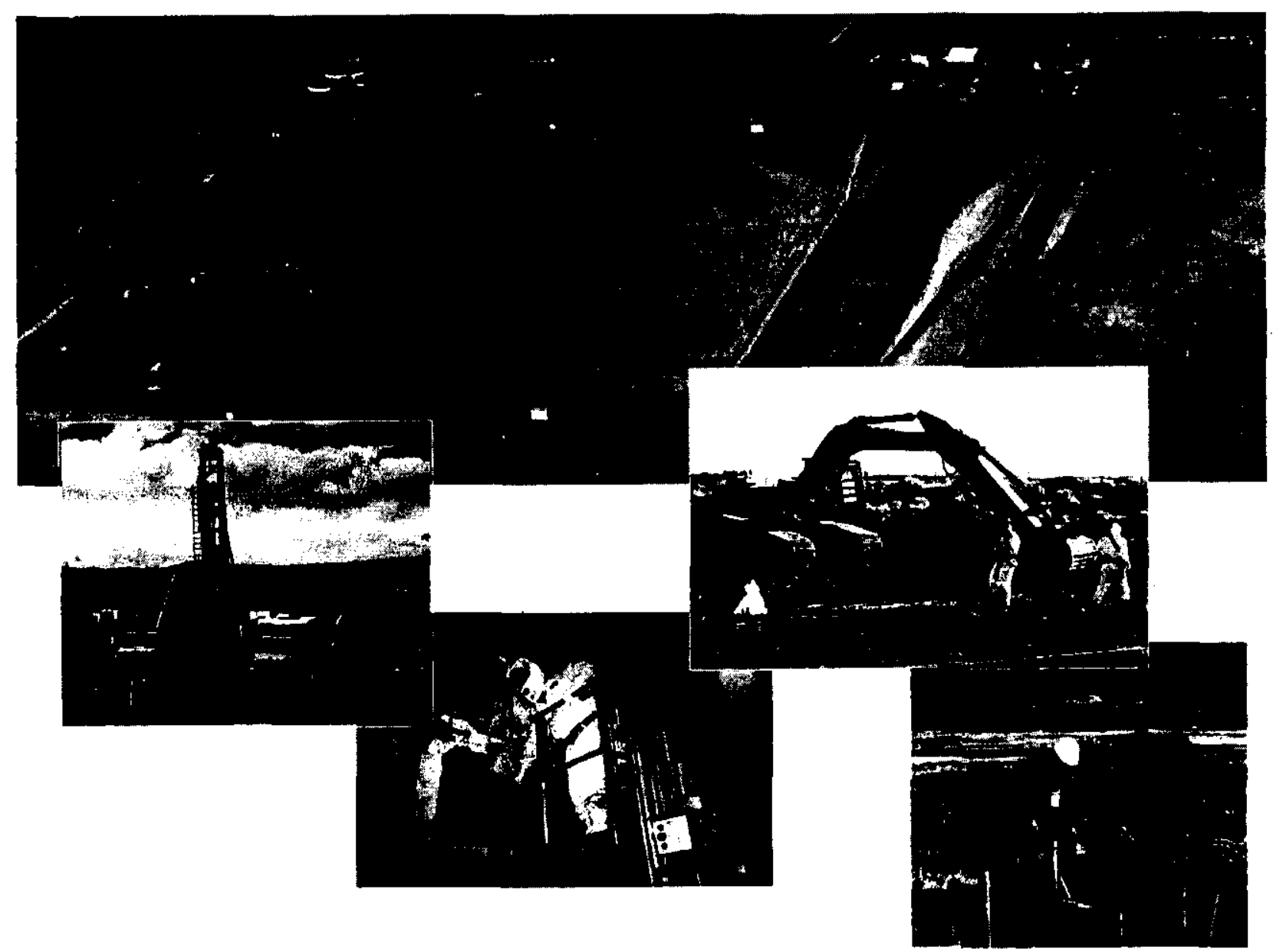

Focused on Progress...

Focused on Outcomes!

Department of Energy Richland Operations Office
Bechtel Hanford, Inc. Environmental Restoration Contractor 


\section{ENVIRONMENTAL RESTORATION PERFORMANCE REPORT ENVIRONMENTAL RESTORATION \\ JULY 2000 \\ TABLE OF CONTENTS}

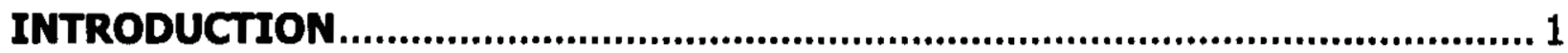

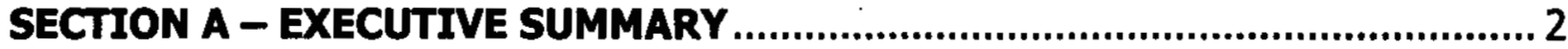

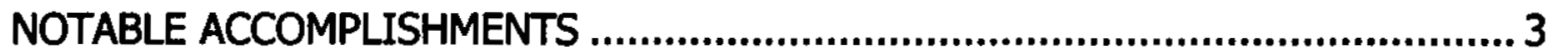

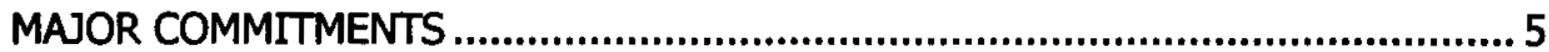

SAFETY/ISMS/CONDUCT OF OPERATIONS ...................................................6

REGULATORY/EXTERNAL/DOE-RL \& HQ ISSUES AND REQUESTS ..................... 10

TOTAL COST/SCHEDULE OVERVIEW........................................................ 11

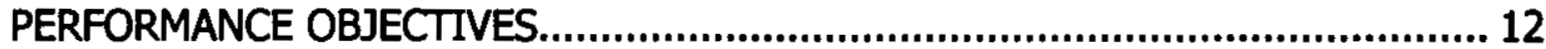

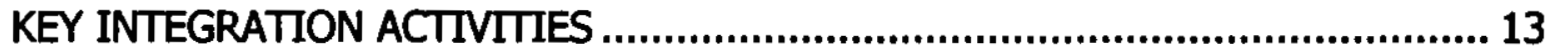

UPCOMING PLANNED KEY EVENTS .............................................................. 13

SECTION B - RESTORING THE RIVER CORRIDOR PROJECT SUMMARIES..... 14

REMEDIAL ACTION AND WASTE DISPOSAL PROJECT .................................. 15

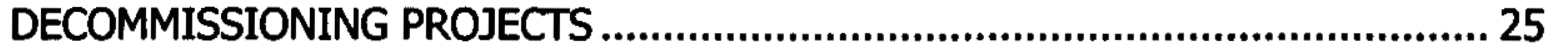

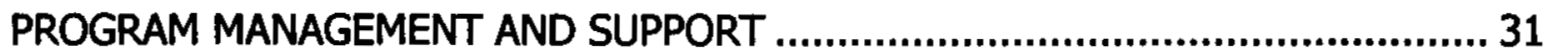

\section{SECTION C - TRANSITIONING THE CENTRAL PLATEAU PROJECT} SUMMARIES

GROUNDWATER/VADOSE ZONE INTEGRATION PROJECT .................................. 37

SURVEILLANCE/MAINTENANCE AND TRANSITION PROJECTS............................ 46 


\section{ENVIRONMENTAL RESTORATION PERFORMANCE REPORT ENVIRONMENTAL RESTORATION \\ JULY 2000}

\section{INTRODUCTION}

The monthly Environmental Restoration (ER) Environmental Management Performance Report consists of three sections: Section A - Executive Summary, Section B - Restoring the River Corridor Project Summaries, and Section C - Transitioning the Central Plateau Project Summaries. All cost, schedule, milestone commitments, performance measures, and safety data is current as of May 31. Accomplishments, Issues and Integration items are current as of June 22, unless otherwise noted.

Section A - Executive Summary. This section provides an executive level summary of Bechtel Hanford, Inc.'s (BHI) performance information for the current reporting month and is intended to bring to Management's attention that information considered to be most noteworthy. The Executive Summary begins with a description of notable accomplishments that are considered to have made the greatest contribution toward safe, timely, and cost-effective cleanup. Major commitments are summarized that encompass Hanford Federal Facility Agreement and Consent Order (Tri-Party Agreement) milestones and FY00 Management Commitment milestones. Safety statistics are also included. Issues that require management and/or regulator attention and resolution status are addressed. Fiscal year-to-date ERC Project cost and schedule variance analysis is summarized. The Key Integration Activities section highlights site activities that cross contractor boundaries and demonstrates the shared value of working as a team to accomplish the work. The Executive Summary ends with a listing of major upcoming planned key events within a 90-day period.

Section B - Restoring the River Corridor. This section contains more detailed monthly activity information and performance status for the three projects within the 'Restoring the River Corridor' outcome. These three projects consist of the Remedial Action and Waste Disposal Project, Decommissioning Projects, and the Program Management and Support (PM\&S) Project.

Section C - Transitioning the Central Plateau. This section contains more detailed monthly activity information and performance status for the two projects within the 'Transitioning the Central Plateau' outcome. These two projects consist of the Groundwater/Vadose Zone (GW/VZ) Integration Project and the Surveillance/Maintenance and Transition (SM\&T) Projects.

Information in this report is identified with a green, yellow, or red text box used as an indicator of the overall status. Green indicates work or issue resolution is satisfactory and generally meets or exceeds requirements; yellow indicates that significant improvement is required; and red indicates unsatisfactory conditions requiring immediate corrective actions. 


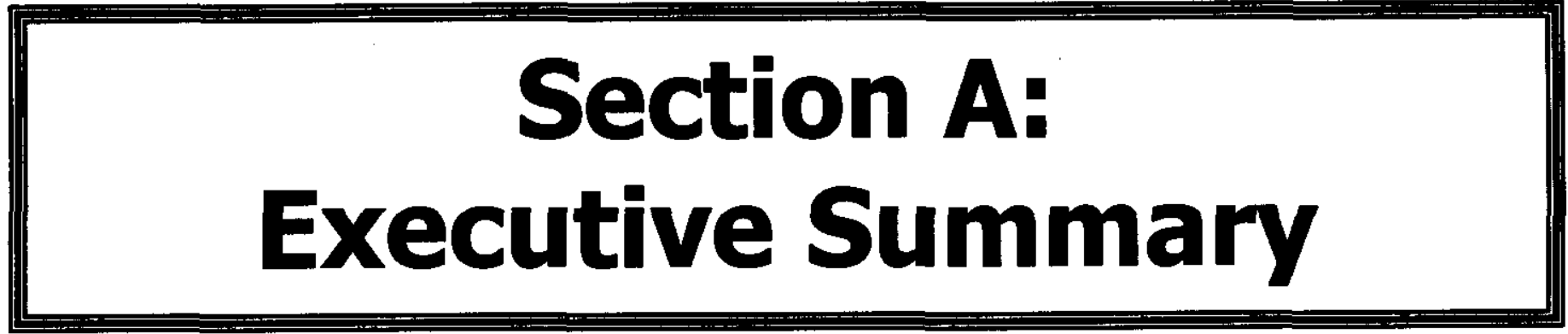




\section{ENVIRONMENTAL RESTORATION PERFORMANCE REPORT ENVIRONMENTAL RESTORATION \\ JULY 2000}

\section{SECTION A - EXECUTIVE SUMMARY}

Financial / Performance Measures data as of month-end May.

All other data as of June 22, 2000 (unless otherwise noted).

\section{NOTABLE ACCOMPLTSHMENTS:}

\section{Alver Corridor:}

On MaY 11, the ERDF transportation organization completed 4 million safe miles of waste hauling without an accident. This major milestone encompasses all remediation work since the first waste shipment was transported to ERDF in 1996.

A Request for Proposal (RFP) for the 100 B/C pipeline remediation is being prepared and is scheduled for completion by August. Subcontractor selection will be completed early in fr 2001.

Excavation of the waste sites and pipelines in the $100 \mathrm{D}$ and $100 \mathrm{H}$ Areas is nearing completion. The backfil subcontractor has begun mobilizing equipment in the 1000 Area.

The remediation subcontractor started mobilization activities in the 100 NArea. Soil remediation at $100 \mathrm{~N}$ Area is on schedule to begin in July to meet the requirements of the Hanford Site RCRA permit.

The Proposed Plan for the 100 Area Burial Grounds Interim Remedial Action, Rev. 1, was transmitted to RL on May 17. The 30-day public comment period was from May 22 through June 20, with a public meeting held in Hood River, Oregon on June 14.

The remaining FY 2000 excavation/remediation activities at the 300 Area 300-FF-1 Operable Unit are nearing completion. Demobilization activities are scheduled for completion by midJuty.

Engineering and planning for the FReactor Fuel Storage Basin (FSB) are underway. A Memorandum of Understanding (MOU) was prepared with Fluor Hanford (FH) to obtain assistance in the event fuel fragments are found during the FReactor FSB deanout.

At the $D$ and $H$ Reactors, room-by-room walkdowns and estimates in accessible areas were completed. The Waste Management Plan for both $D$ and H Reactors was also approved.

Cleanup and decontamination of the process hood Hoor was completed in the 233-5 Plutonium Concentration Facility during May. A total of 51 polyjars (0.5 liter in size) of loose material was collected.

Results from the FY 1999 Procurement DOE Complex Balanced Score Card (BSC) indicate that Bechtel Hanford, InC. (BHI) shared the highest score in the DOE complex in 4 of the 11 categories tracked by DOE. This is the second year in a row that BHI received the highest score in four categories, and this repeats prior high performance in the "Customer Satisfaction" and "Information Availability" categories. This is especially significant since the number of major DOE facility contractors participating in the BSC process has almost doubled, and now indudes almost all of the major DOE complex contractors. For all of the remaining categories in which BHI participated, ERC's score was significantly above the DOE complex average.

The ER Project was recagnized by the Secretary of Energy with a Certificate of Appreciation for contributions to DOE's mission to prevent pollution in operations, processes, and programs. 


\section{ENVIRONMENTAL RESTORATION PERFORMANCE REPORT ENVIRONMENTAL RESTORATION \\ JULY 2000}

\section{NOTABLE ACCOMPLISHMENTS:}

\section{Contral Plateau:}

The Groundwater/ Vadose (GWNZ) Integration Project conducted project briefings for HQ management and members of Senator Wyden's staff in Washington D.C. The expert panel meeting was also conducted in May.

The Semi-Annual GroundwaterNadose Zone Report to Congress was completed on May 31. Completion of this report satisfied a Fr 2000 management commitment milestone.

The Science and Tectinology (S\&T) Raadmap Rev. 1 was completed. This revision to the document incorporated revisions to Inventory, Vadose Zone, Groundwater, and River technical elements. The Risk element in the WMA S-SX field investigation report was also added.

Draft A of the System Assessment Capability (SAC) Rev. O, Assessment Description, Requirements, Software Design and Test Plan was completed, and is being reviewed by RL.

The design for the In SitU REDOX Manipulation (ISRM) evaporation pond was completed, and the construction bid package was issued for bid.

All five groundwater pump and treat systems continued removing contaminants from the groundwater. All operated above cumulative planned avallability through May.

Legacy waste removal was completed at both the KE and KW Reactors in May. The legacy waste removal scope was verified to be satisfactorily completed by $R L$ field inspection of the work sites and review of work packages and shipping documents.

Legacy waste removal was initiated at H Reactor in May.

Nineteen of the planned 26 cells have been accessed at the U Plant (221-U Building) canyon facility in FY 2000 in support of the Canyon Disposition Initiative (CDI).

Training was completed on the Brokk coring machine. This equipment will take concrete core samples inside the CDI access cells, and will be remotely operated by the canyon cane.

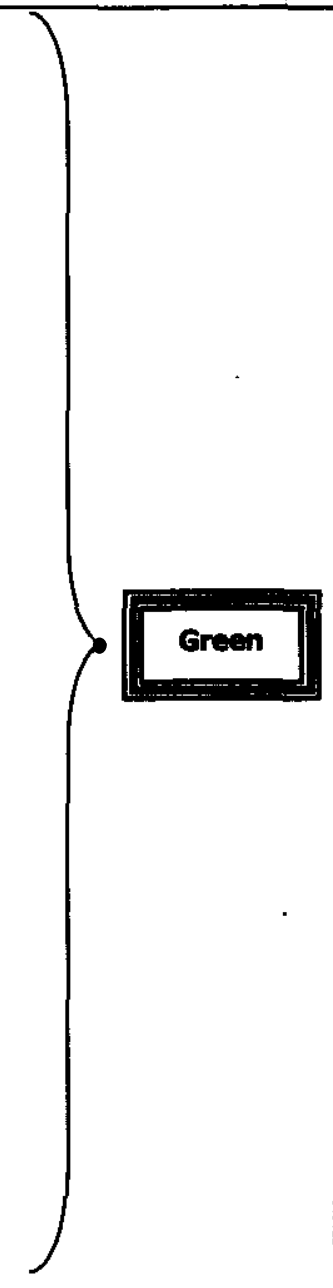




\section{ENVIRONMENTAL RESTORATION PERFORMANCE REPORT ENVIRONMENTAL RESTORATION \\ JULY 2000}

\section{MASOR COMMITMENTS:}

Tri-Party Agreement Millestones:

Twe/ve Tri-Party Agreement milestones have been completed through May, all ahead of schedule.

\begin{tabular}{|l|c|}
\hline Total Tri-Party Agreement Milestones Due in Froo & 16 \\
\hline Total Planned Through May & 12 \\
\hline Total Completed Through May & 12 \\
\hline
\end{tabular}

\begin{tabular}{|l|c|}
\hline Remaining Tri-Party Agreement Mllestones to be Completed in Froo & 4 \\
\hline Forecast Ahead of Schedule & 1 \\
\hline Forecast On Schedule & 3 \\
\hline Unrecoverable & 0 \\
\hline
\end{tabular}

Froo Management Comm/tment Mllestones:

Transmit Update of the Vadose Zone Science and Technology Roadmap (PBS VZ01) due April 30.

Status: Complete. Draft was transmitted to RL on April 28.

Install Wells and Initiate Injection of the Barrier for Phase I of the In Situ REDOX Groundwater Remediation (PBS EROB) due September 30.

Status: Forecasted for completion by September 30. (16-well installation completed on April 24.)

Complete the Semi-Annual GroundwaterN Nadose Zone Report (December 1999 - March 2000) (PBS V201) due May 31.

Status: Complete. Final document was transmitted to RL on May 31.

EM Corporate Performance Measures:

\begin{tabular}{|l|c|c|c|c|c|}
\hline & $\begin{array}{c}\text { DWP } \\
\text { FY00 }\end{array}$ & $\begin{array}{c}\text { FY00 Mgmt } \\
\text { Commitments }\end{array}$ & $\begin{array}{c}\text { Current } \\
\text { Baseline }\end{array}$ & $\begin{array}{c}\text { Forecast } \\
\text { for FY00 }\end{array}$ & $\begin{array}{c}\text { Completed } \\
\text { YTD }\end{array}$ \\
\hline $\begin{array}{l}\text { Waste Site } \\
\text { Assessments }\end{array}$ & 121 & 167 & 168 & 168 & 168 \\
\hline $\begin{array}{l}\text { Waste Ste } \\
\text { Closnups }\end{array}$ & 24 & 41 & 40 & 40 & 16 \\
\hline $\begin{array}{l}\text { Technology } \\
\text { Deployments }\end{array}$ & 0 & 4 & 4 & 4 & 1 \\
\hline
\end{tabular}




\section{ENVIRONMENTAL RESTORATION PERFORMANCE REPORT ENVIRONMENTAL RESTORATION \\ JULY 2000}

\section{SAFETY/ISMS/CONDUCT OF OPERATIONS (Total ER Contract): Cows-autting Information}

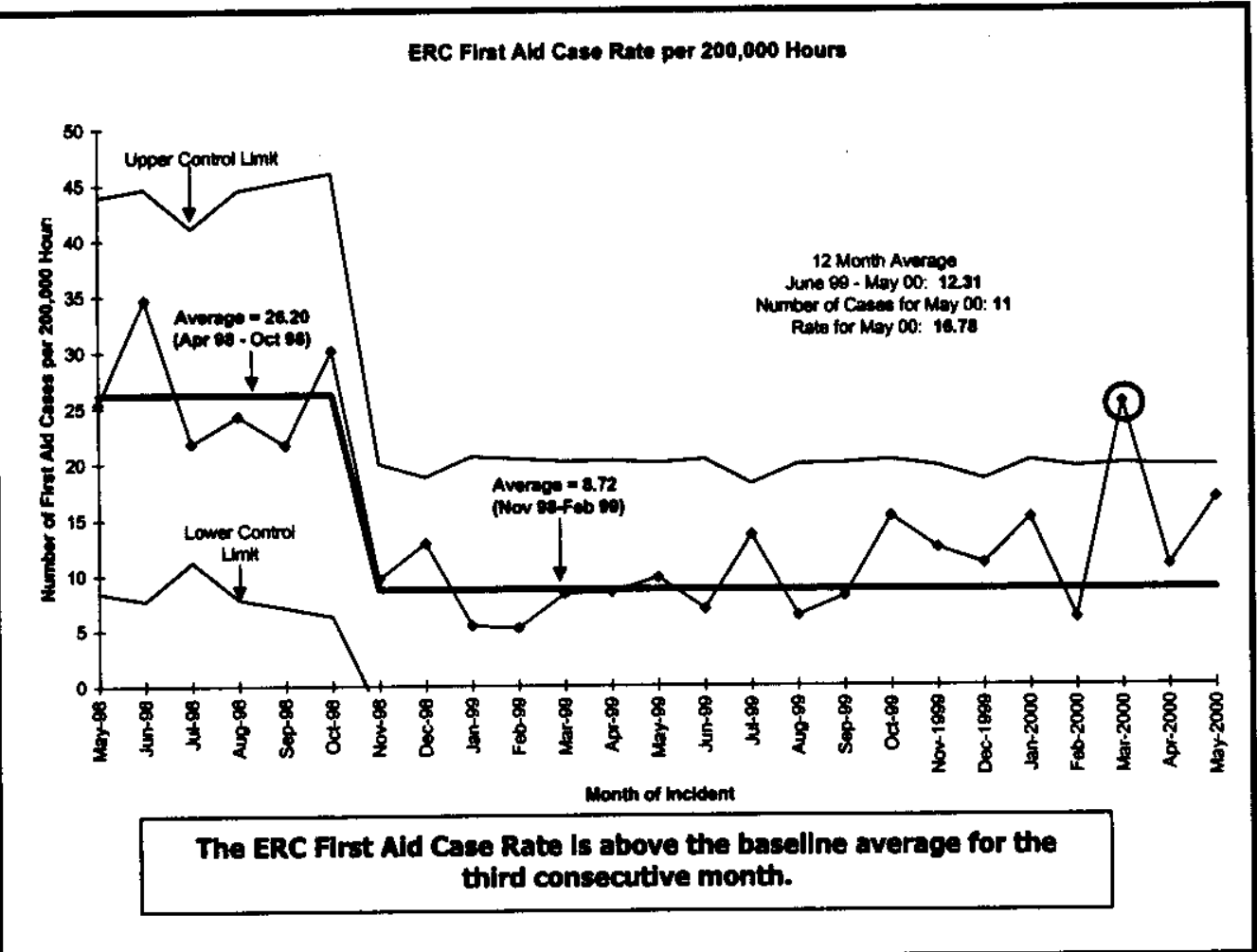

ERC Rocordable Case Rato/200,000 Hours

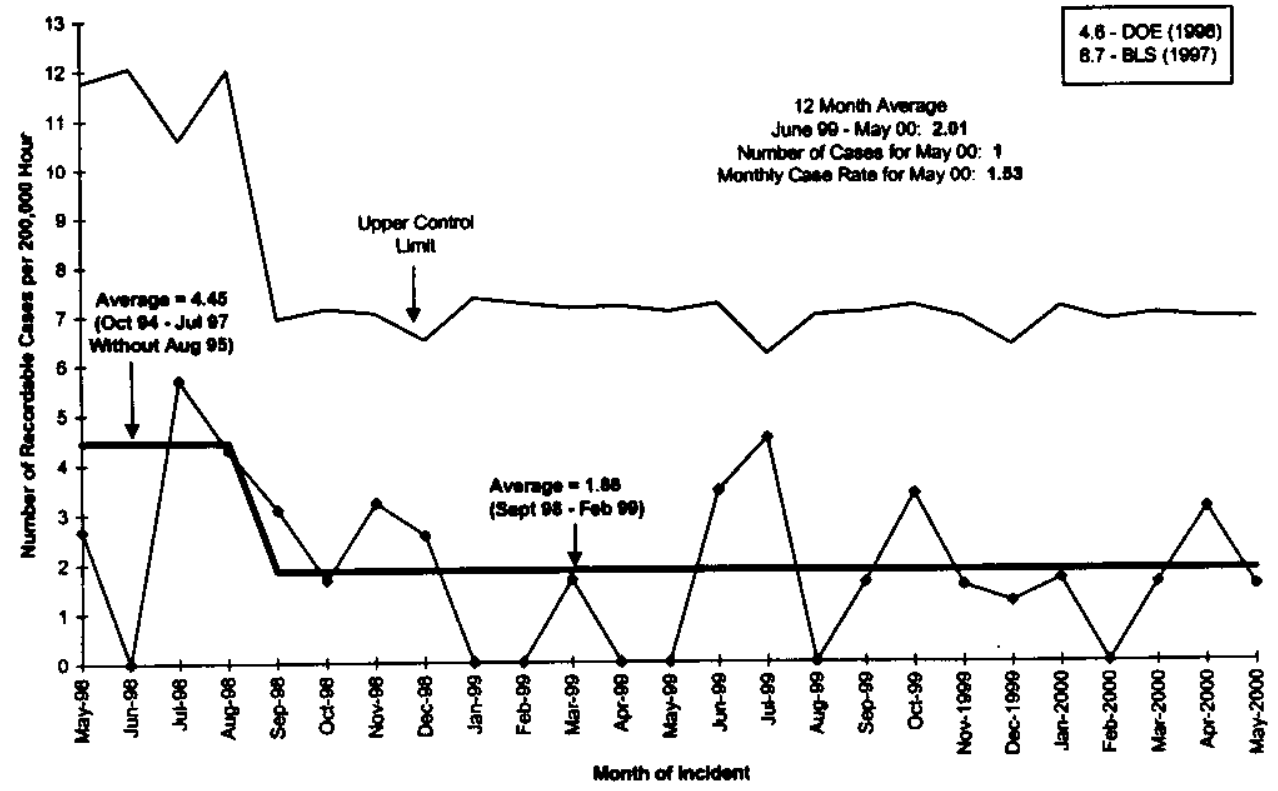

The ERC Recordable Case Rate for May Is again below the basellne average. Data has been stable since September 1998. 


\section{ENVIRONMENTAL RESTORATION PERFORMANCE REPORT ENVIRONMENTAL RESTORATION \\ JULY 2000}

\section{SAFETY/ISMS/CONDUCT OF OPERATIONS (Total ER Contract) continued: Cross-auting Information}

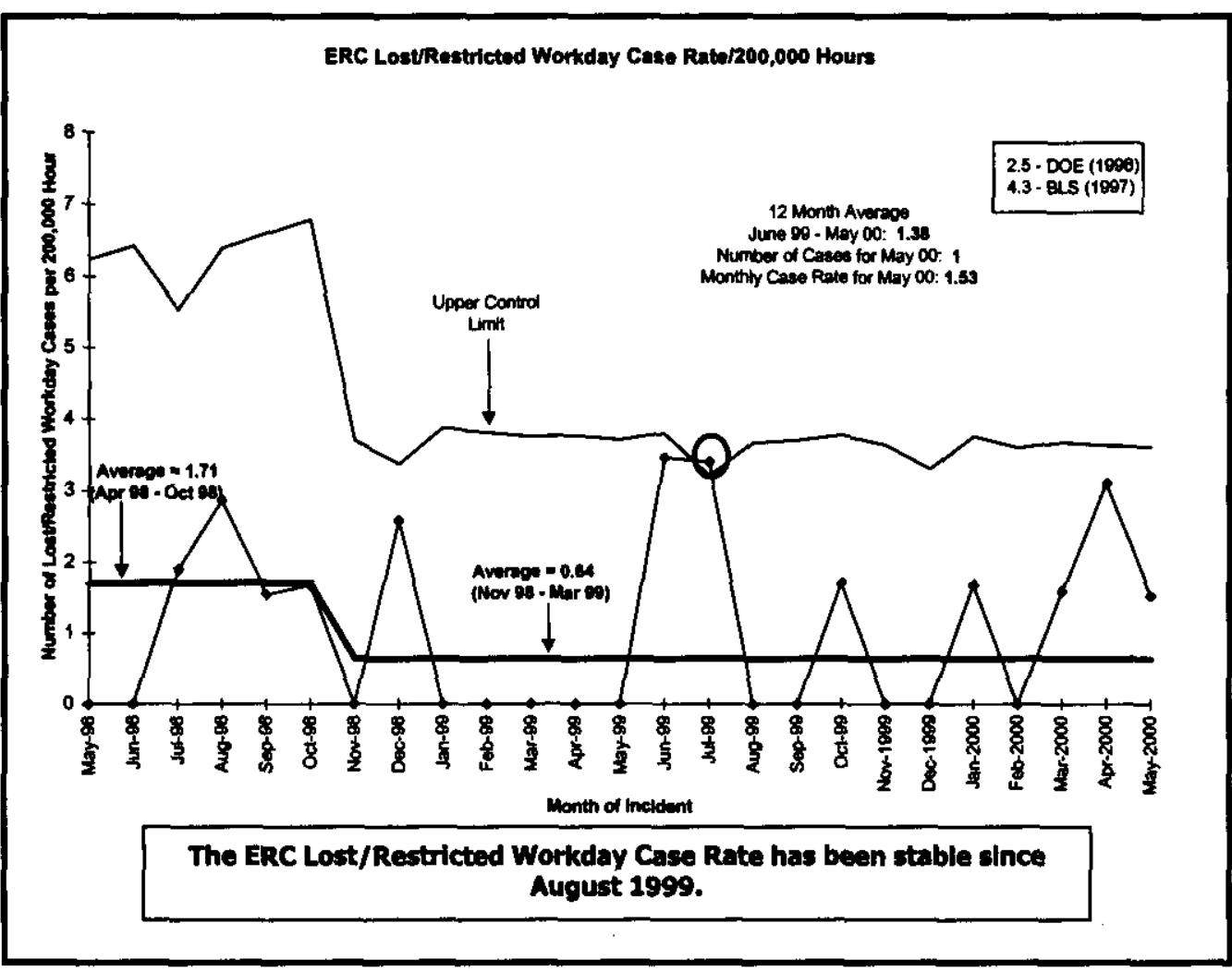

\begin{tabular}{|c|c|c|c|}
\hline \multirow[t]{2}{*}{ Sofoty: } & \multicolumn{3}{|c|}{ 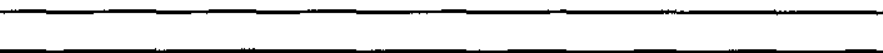 } \\
\hline & YTD & $\begin{array}{l}\text { Current } \\
\text { Month } \\
\text { (May) }\end{array}$ & Current Month Comments \\
\hline Flost $A$ No & 73 & 11 & $\begin{array}{l}\text { (1) puncture, (3) sprains/strains, (3) } \\
\text { contusions, (2) lacerations, (1) bite/sting, } \\
\text { (1) bum }\end{array}$ \\
\hline Restricted Workday Case & 5 & 1 & (1) sore left elbow* \\
\hline Last Workday Case & 1 & 0 & $N / A$ \\
\hline OSHA Recordable & 9 & 1 & $\begin{array}{l}\text { (1) sore left elbow (*same incident as } \\
\text { above) }\end{array}$ \\
\hline
\end{tabular}




\section{ENVIRONMENTAL RESTORATION PERFORMANCE REPORT ENVIRONMENTAL RESTORATION

\author{
JULY 2000
}

SAFETY/ISMS/CONDUCT OF OPERATIONS (Total ER Contract) continued: Cross-autting Information

ISMS:

DOE EM Performance Agreement: Develop and implement Integrated Safety Management (ISM) - September 30, 2000

Status:

- Since last month, the ERC has received validation for both Phase I and Phase II of ISMS.

- The action plan transmitted to Keith Klein is still on schedule for completion by the end of the fiscal year.

- In addition, the ERC Team made a presentation in which an overview of our ISMS Implementation Strategy was given to the following RL personnel: Harry Boston, Beth Bilson, Shiv Seth (representing Pete Knollmeyer), and Doug Shoop.

- The integration of the ISMS program into the Environment, Safety, and Health Handbook has been initiated. This handbook will be issued to all ERC emplovees this summer.

- The BHI Baard of Directors was debriefed on the ISMS Implementation Status and the path forward for ISMS.

- The Detalled Work Plan (DWP) for FY 2001 is currently under development. ISMS Program responsibility will be transitioned to the QS\&H Department Manager for the next fiscal year. 


\section{ENVIRONMENTAL RESTORATION PERFORMANCE REPORT ENVIRONMENTAL RESTORATION \\ JULY 2000}

\section{SAFETY/TSMS/CONDUCT OF OPERATIONS (Total ER Contract) continued: Crass-autting Information}

\section{conduct of Ops:}

ERC-CATS (Corrective Action Tracking System) Trend Data 6/1/99 through 5/31/00

\begin{tabular}{|c|c|c|c|c|c|c|c|c|c|c|c|c|}
\hline & thon & Jaten & Angen & $\operatorname{sen}-\infty$ & Octen & Noven & Decte & $\tan 0$ & Fob 00 & Mer $\infty$ & Apen $\overline{0}$ & Now \\
\hline Lock \& Ter & 0 & 0 & 0 & 0 & 0 & 0 & 0 & 0 & 0 & 0 & 2 & 0 \\
\hline 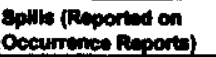 & 0 & 0 & 1 & 0 & 0 & 0 & 0 & 0 & 0 & 0 & 0 & 0 \\
\hline Procecenen Voldetions & $i$ & 1 & 1 & 1 & 1 & 2 & 6 & 3 & 1 & 0 & 1 & 0 \\
\hline 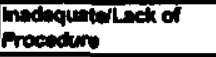 & 4 & 0 & 0 & 1 & 1 & 1 & 2 & 1 & 3 & 2 & 0 & 0 \\
\hline Monserement Prowleme & 4 & 1 & 1 & 1 & 1 & 2 & 0 & 1 & 2 & 2 & 3 & 1 \\
\hline
\end{tabular}

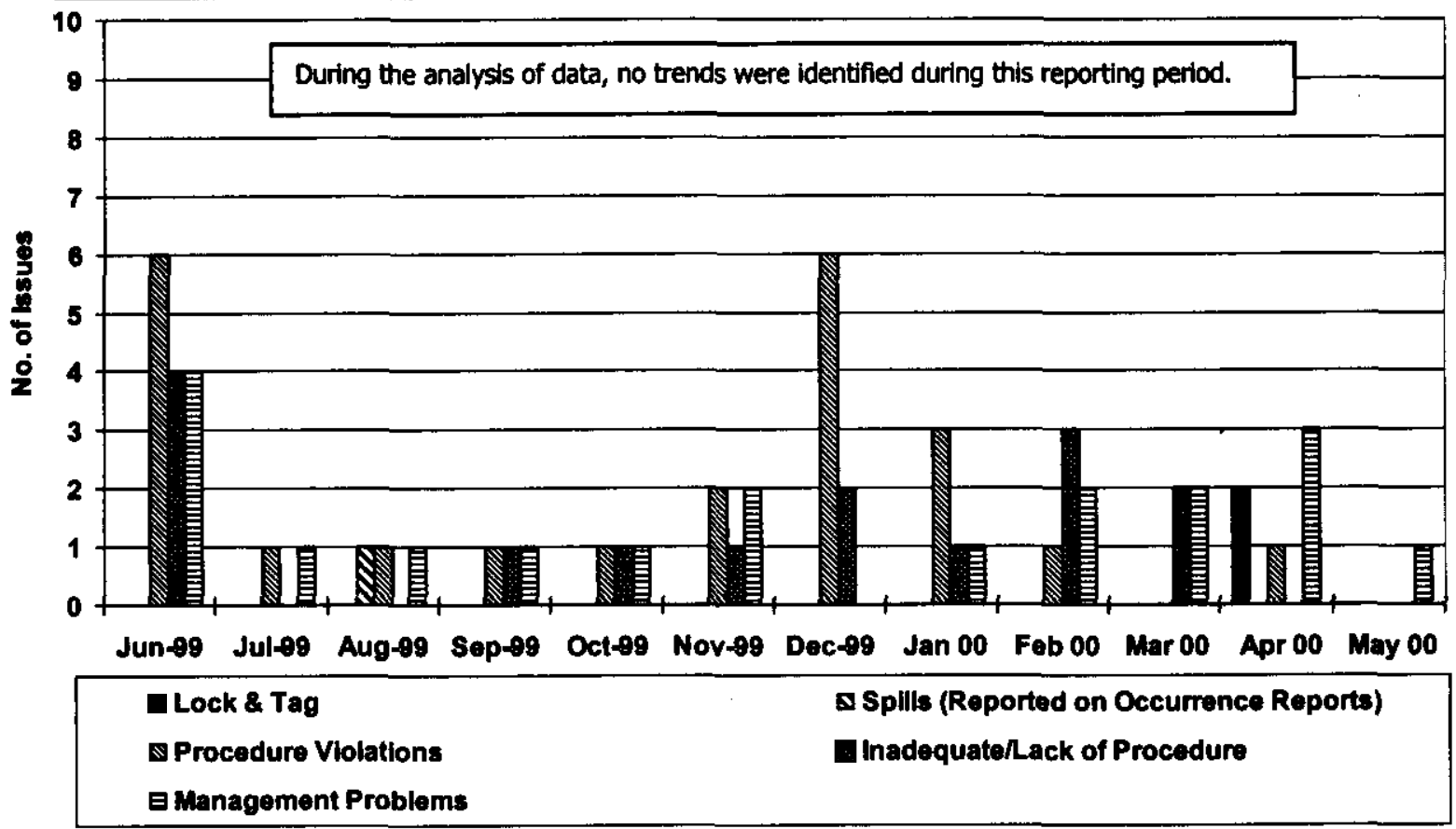

Each potential trend is evaluated for impact on the project, and then given the appropriate level of attention based on a graded approach.

\section{Mav Conduct of Ons Trever:}

\section{Management Problem:}

Condition Description: (a) The Emergency Action Plan (EAP) for the 271.U <90-day Hazardous Waste Storage Units was not updated in accordance with Washington Administrative Code (WAC) 303-350-5. The emergency equipment list posted for the spill kit identified spill equipment that was not reflected in the EAP. (b) BHI-SH-03, Vol. 1 does not reflect the need to immediately amend EAPs per the above requirement. (c) The personnel responsible for the 271-U and 1330-N <90-day Hazardous Waste Storage Units were not aware of the requirement to "immediately amend" the EAPS whenever the emergency equipment for the storage units change.

Corrective Action Plan: (a) The EAP has since been changed (March 9). This procedure was changed to reflect this requirement. (b) Revised BHI-SH-03, Vol. 1 to reflect the need to immediately amend EAPs in accordance with WAC 303-350-5. (c) Project personinel involved with the storage of waste will read and understand the revised requirements of $B H I-S H-O 3$, Vol. 3 Section 8.0, Rev. 2, along with Revision Order A. 


\section{ENVIRONMENTAL RESTORATION PERFORMANCE REPORT ENVIRONMENTAL RESTORATION JULY 2000}

\section{BREAKTHROUGHS/OPPORTUNIIIES FOR IMPROVEMENT: COSS-aitting Information}

None identified at this time.

REGULATORY/EXTERNAL/DOE-RL \& HQ ISSUES AND REQUESTS: Cass-auting Intormation

Site-Wide Senionthy (SWG): Current BHI/THI manual staffing totals 271 personnel. Approximately 225 position openings will become available within the (Fluor Hanford) FH organization during FY 2000. Currently, 49 BHI/THI personnel have applied for transfer through the Labor Assets Management Program (LAMP) process. Continued loss of personnel will result in additional costs and potential impacts to critical work path activities.

Status: Lamping of ERC personnel has begun. For the months of January through May, 25 personnel have transferred to FH. A site-wide strategy is required to maintain trained and critical resources on ER work. Lamping of personnel has resulted in additional costs associated with the training of new personne/ without compensation from the receiving organization.

Radiologlcal Control Tectiniclan (RCT) and Industrial Hygiene Technlian (IHI) Lamplng: 36\% tumover in RCTs and $50 \%$ tumover for IHTs during the last 20 months (collectively the THI HAMTC tumover for LAMPS is 37.5\%)

Impreas:

(1) It costs $~ \$ 20 K$ each to recruit RCTs from the outside and train them (this does not include the costs to projects for delays and overtime required to support the work operations due to RCT shortages).

(2) This high tumover rate impacts BHI's ability to assure continuity in compliance.

Stotus:

(1) BHI has initiated discusssions with PHMC to attempt promoting a site-wide solution to the RCT shortage problem. The RCT shortage is a nation-wide problem. BHI would like to promote resurrecting the Columbia Basin College two-year academic program for RCTs.

(2) BHI Labor Relations and THI are in the process of developing incentives to reduce the number of RCTs from Lamping to another contractor.

IMPORTANT INTEGRATION ACTIVITIES: Cross-autting Information

None identified at this time. 


\section{ENVIRONMENTAL RESTORATION PERFORMANCE REPORT ENVIRONMENTAL RESTORATION \\ JULY 2000}

TOTAL COST/SCHEDULE OVERVIEW (Total ER Contract): cross-autting Information

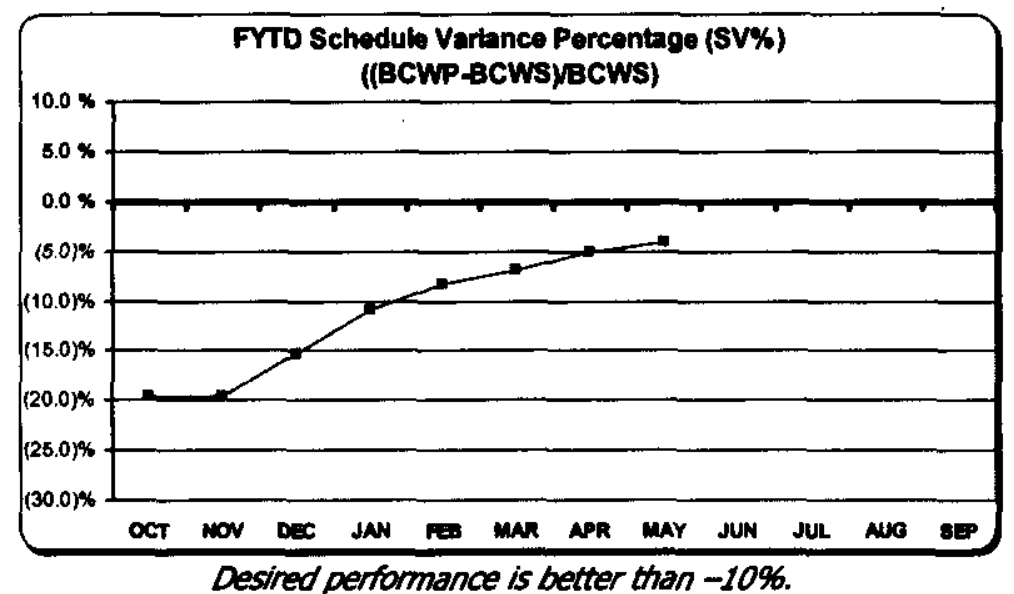

\begin{tabular}{|c|c|c|c|c|c|c|c|c|c|c|c|c|}
\hline & OCI & NOV & DEC & SAN & FL & MAR & $\overline{A P R}$ & $\overline{m a y}$ & उण्य & JUL & RUG & $\xi=$ \\
\hline $\begin{array}{l}\text { DWP } \\
\text { DWP (acesure }\end{array}$ & $\begin{array}{l}11,612 \\
11,612\end{array}$ & $\begin{array}{l}10,506 \\
22,118\end{array}$ & $\begin{array}{l}10,211 \\
32,330\end{array}$ & $\begin{array}{l}12,760 \\
45,090\end{array}$ & $\begin{array}{l}10,155 \\
55,245\end{array}$ & $\begin{array}{l}10,793 \\
66,037\end{array}$ & $\begin{array}{l}12,259 \\
78,296\end{array}$ & $\begin{array}{l}10,599 \\
88,895\end{array}$ & $\begin{array}{l}10,197 \\
99,092\end{array}$ & $\begin{array}{r}12,369 \\
111,491 \\
\end{array}$ & $\begin{array}{r}10,820 \\
122,301 \\
\end{array}$ & $\begin{array}{r}12,798 \\
135,100\end{array}$ \\
\hline $\begin{array}{l}\text { ECWS } \\
\text { BCWP }\end{array}$ & $\begin{array}{l}14,556 \\
11,711\end{array}$ & $\begin{array}{l}8,508 \\
6,838 \\
\end{array}$ & $\begin{array}{l}12,269 \\
11,396\end{array}$ & $\begin{array}{l}15,102 \\
15,035\end{array}$ & $\begin{array}{l}13,068 \\
13,339\end{array}$ & $\begin{array}{l}\text { ERIOD } \\
13,45 \\
13,352\end{array}$ & $\begin{array}{l}15,190 \\
15,797\end{array}$ & $\begin{array}{l}12,158 \\
12,550\end{array}$ & 12,028 & 14,392 & 11,524 & 15,5 \\
\hline $\begin{array}{l}\text { ECWS } \\
\text { BcW } \\
\text { sy } \\
\text { syen }\end{array}$ & $\begin{array}{c}14,558 \\
11,711 \\
(2,847 \\
-19.6 \%\end{array}$ & $\begin{array}{l}23,066 \\
18,550 \\
(4,516) \\
-19.6 \%\end{array}$ & $\begin{array}{c}35,354 \\
29,946 \\
(5,408) \\
-15.3 \%\end{array}$ & $\begin{array}{l}50,456 \\
44,981 \\
(5,475) \\
-10,9 \%\end{array}$ & $\begin{array}{r}C A 1 Y[A \\
63,524 \\
58,320 \\
(5,204) \\
8.2 \%\end{array}$ & $\begin{array}{r}\text { TO DA } \\
76,969 \\
71,672 \\
(5,297) \\
6,9 \%\end{array}$ & $\begin{array}{r}92,159 \\
87,469 \\
(4,690) \\
-5.1 \%\end{array}$ & $\begin{array}{r}104,317 \\
10,0019 \\
(4,298) \\
4,1 \%\end{array}$ & 116,345 & 130,737 & 142,262 & 157,8 \\
\hline
\end{tabular}

For variance explanation by PBS, see Project Status Section of each project.

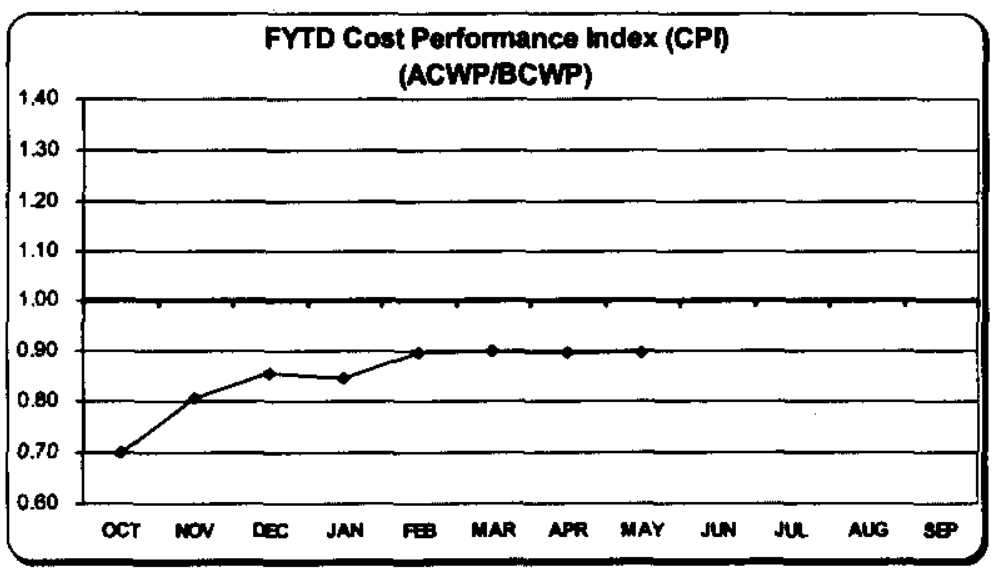

Desired performance is 1.0 or less.

\begin{tabular}{|c|c|c|c|c|c|c|c|c|c|c|c|c|c|}
\hline & OCT & mov & $D C$ & JNA & का & man & $M P$ & MAY & JuN & JuL & AUE & 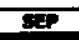 & TCURYY OVLA \\
\hline $\begin{array}{l}\text { ACWP } \\
\text { BCWP }\end{array}$ & $\begin{array}{r}8,190 \\
11,711\end{array}$ & $\begin{array}{l}6,786 \\
6,838\end{array}$ & $\begin{array}{l}10,729 \\
11,396\end{array}$ & $\begin{array}{l}12,465 \\
15,035\end{array}$ & $\begin{array}{l}14,171 \\
13,338\end{array}$ & $\begin{array}{r}12,199 \\
13,352\end{array}$ & $\begin{array}{l}14,037 \\
15,797\end{array}$ & $\begin{array}{l}11,240 \\
12,550\end{array}$ & & & & & \\
\hline $\begin{array}{l}\text { ACWP } \\
\text { CCWP } \\
c \mathbf{P} \\
C \mathrm{PI}\end{array}$ & $\begin{array}{r}8,190 \\
11,711 \\
3,521 \\
0,70\end{array}$ & $\begin{array}{r}14,976 \\
18,550 \\
3,574 \\
0.81\end{array}$ & $\begin{array}{r}25,705 \\
29,946 \\
4,240 \\
0.86\end{array}$ & $\begin{array}{r}\text { TO DAT } \\
38,170 \\
4,981 \\
6,811 \\
0.85\end{array}$ & $\begin{array}{r}52,341 \\
58,320 \\
5,978 \\
0.90\end{array}$ & $\begin{array}{r}64,540 \\
7,672 \\
7,131 \\
0,90\end{array}$ & $\begin{array}{r}78,577 \\
87,469 \\
8,892 \\
0.90\end{array}$ & $\begin{array}{r}89,818 \\
100,019 \\
10,201 \\
0.90\end{array}$ & 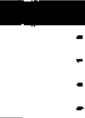 & & & 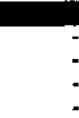 & \\
\hline 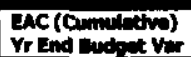 & $\begin{array}{l}8,190 \\
1,967\end{array}$ & $\begin{array}{r}14,976 \\
3,638\end{array}$ & $\begin{array}{r}25,705 \\
4,793\end{array}$ & $\begin{array}{r}38,170 \\
5,074\end{array}$ & $\begin{array}{r}52,341 \\
5,521\end{array}$ & $\begin{array}{r}64,540 \\
5,482\end{array}$ & $\begin{array}{r}78,577 \\
6,206\end{array}$ & $\begin{array}{r}89,818 \\
7,693\end{array}$ & 104,998 & 121,404 & 133,554 & 148,021 & $\begin{array}{r}150,149 \\
2,128\end{array}$ \\
\hline
\end{tabular}

For variance explanation by PBS, see Project Status Section of each project. 


\section{ENVIRONMENTAL RESTORATION PERFORMANCE REPORT ENVIRONMENTAL RESTORATION \\ JULY 2000}

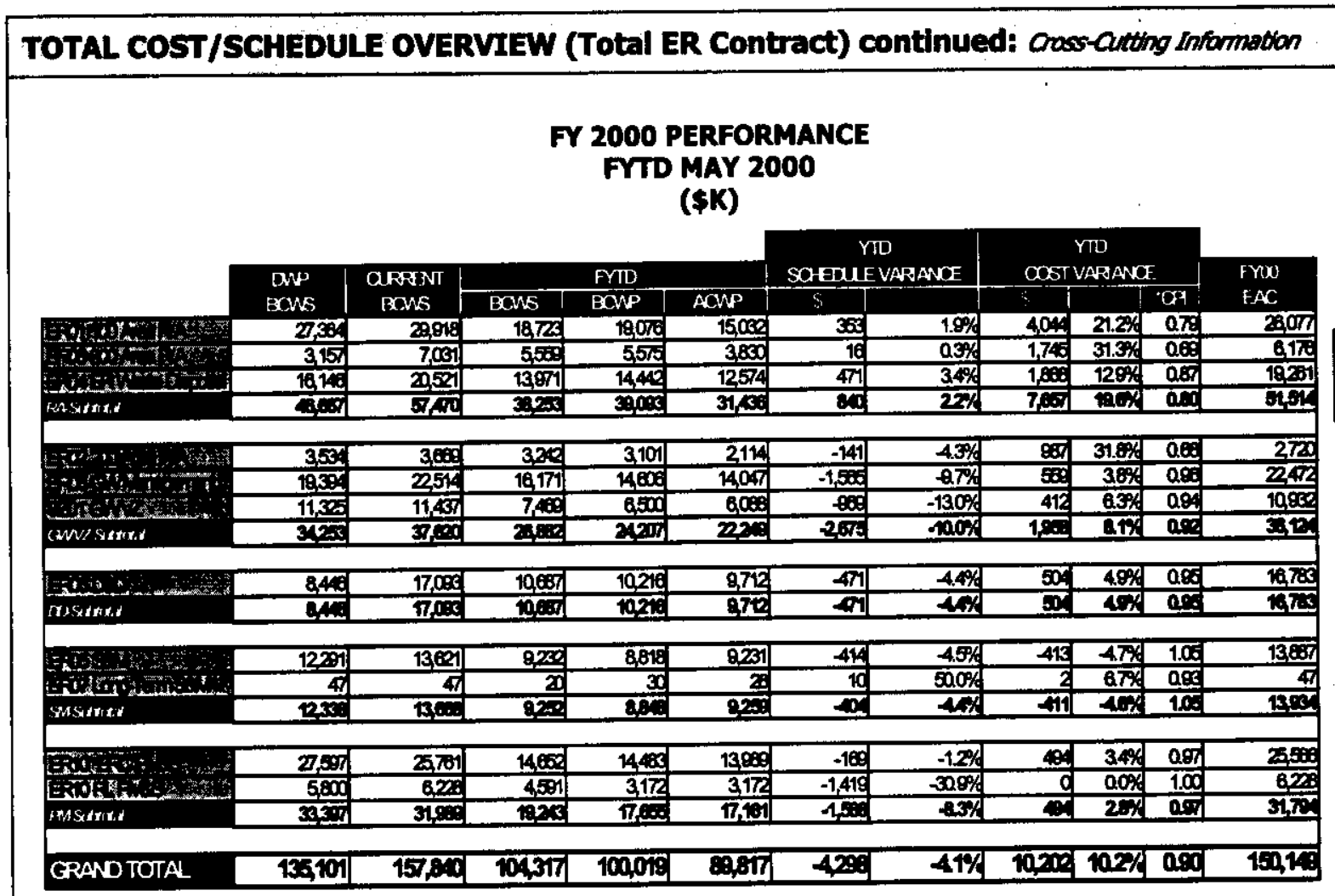

${ }^{*} C P I=A C W P / B C W P$

\section{cost/schedule shturs}

Cast Vartance

At the end of May, the ER Project had performed \$100.0M worth of work, at a cost of \$89.8M. This accounts for a favorable cost variance of $\$ 10.2 \mathrm{M}(10.2 \%)$. The positive cost variance is attributed to DR subcontract savings due to asbestos abatement changes and sampling efficiencies, site excavation/backfill savings, FR savings in site prep and staff reductions, borehole drilling and test pit trenching costs less than planned (due to efficiencies), earty completion of ISRM drilling, and FY 1999 year-end accrual reversals.

\section{Schedule Variance}

The ER Project is \$4.3M (-4.1\%) behind schedule for May. The negative schedule variance is attributed to delayed GW/NZ Integration Project S\&T activities, Subpanel meeting dates, and formation of characterization core team; delayed groundwater well maintenance (resin regeneration) and monitoring; 233-S Facility roof duct removal, sampling, and analysis; weather delays in herbicide application; procurement for S\&M Authorization Basis Development contract deferred due to change in implementation strategy (three contractors rather than one); and late billings for site-wide assessments.

\section{PERFORMANCE OBJECTIVES: COAs-auting Information}

River Comidor Initiatuve (Complete remediation of 60 sq. miles, including Hanford townsite): Initiative is currently identified as a Superstretch item, with an approximate value of \$5. OM. HIgh vislbillty public access opportumities; also a Superstretch item (bike trail, raad to $B$ Reactor, and boat ramp at Hanford townsite). Feasibility plan completed; evaluating options. 


\section{ENVIRONMENTAL RESTORATION PERFORMANCE REPORT ENVIRONMENTAL RESTORATION \\ JULY 2000}

KEY INTEGRATION ACTIVIIES:
300 Ares Acceleration: BHI supported FH in the development of an accelerated closure
plan.
Status: The BHI involvement is nearing the end. The Task Order ends on July 1.
BHI has provided the technical volumes for D\&D and Remedial Action. These
tectnical volumes indude scope, schedule, cost, and the methodology of the
estimating. BHI is assisting in the final write-up of the FH deliverable to RL. FH
completed an Independent Cost Evaluation (ICE) of the technical volumes and
positive comments were provided.
Spont Nudaar Fuel (SWF): Draft waste shipping and receiving plans (WSRPs) were prepared
in support of the upcoming K Basin waste shipments to ERDF expected in June.
UPCOMING PLANNED EVENTS:
Tri-Party Agreement Milestone M-93-05, Issue B Reactor Phase II Feasibility Study Engineering
Design Report for Public Comment, due June 30.
Tri-Party Agreement Milestone M-13-23, Submit 200-TW-1 Workplan, due August 31.
Tri-Party Agreement Milestone M-13-24, Submit 200-TW-2 Workplan, due August 31.
Tri-Party Agreement Milestone M-16-13A, Initiate Remedial Action in the 100-FR-1 Operable
Unit, due September 29.




\section{Richland Operations Office Environmental Restoration \\ Environmental Management Performance Report}

\section{Section B - River Corridor Informzilio lz}

July 2000

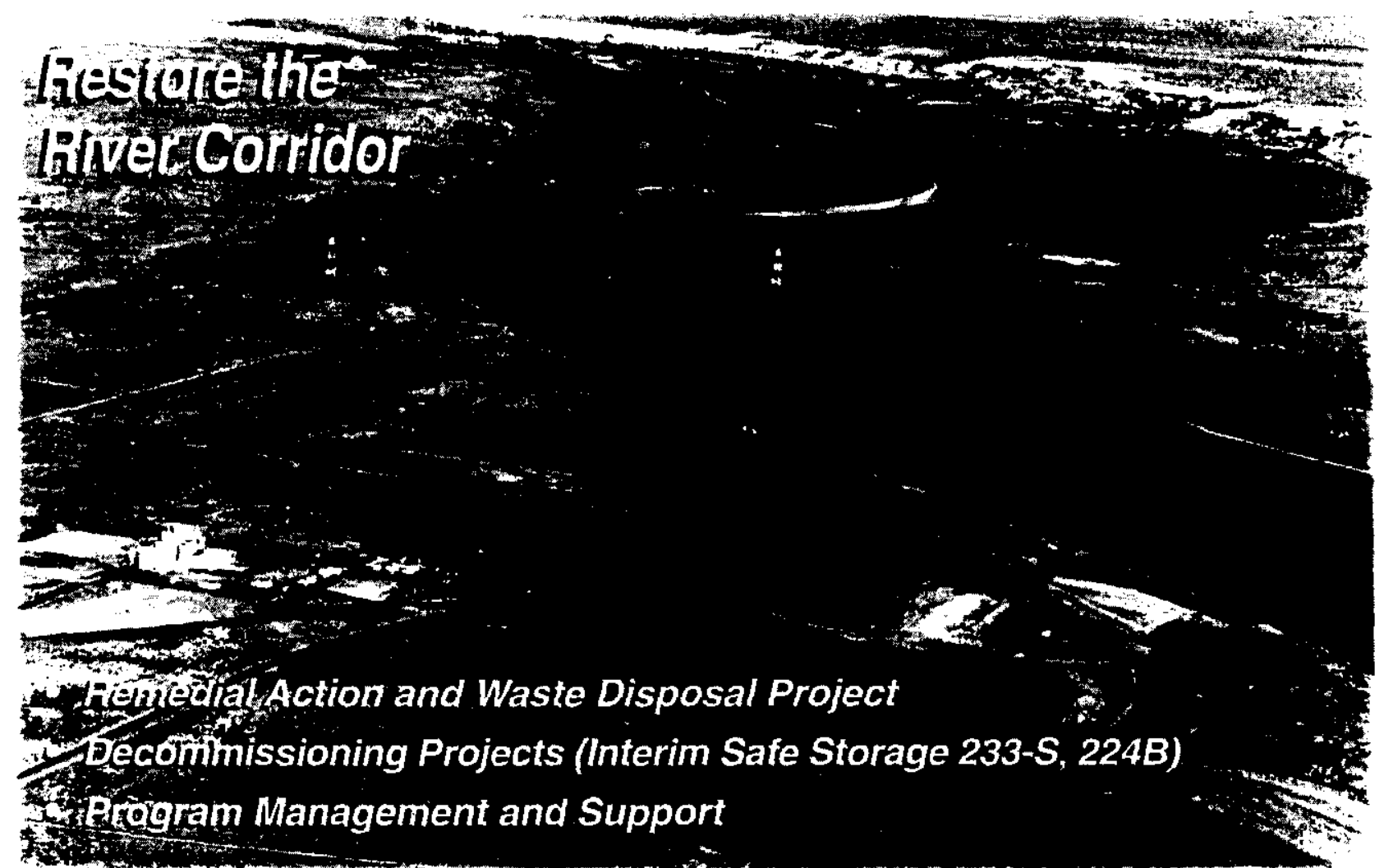

\section{Focused on Progress... \\ Focused on Outcomes!}

Department of Energy

Richland Operations Office
Bechtel Hanford, Inc.

Environmental Restoration Contractor 


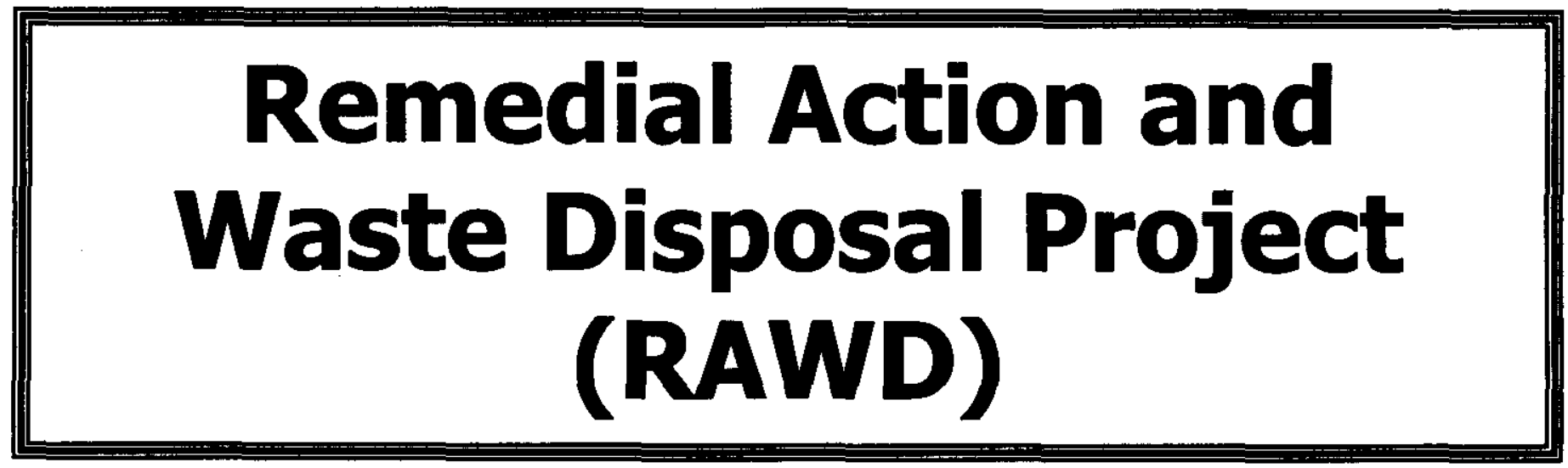




\title{
ENVIRONMENTAL MANAGEMENT PERFORMANCE REPORT ENVIRONMENTAL RESTORATION \\ JULY 2000
}

\section{SECTION B - RESTORING THE RIVER CORRIDOR}

\author{
Financial / Performance Measures data as of month-end May. \\ All other data as of June 22, 2000 (unless otherwise noted). \\ Remedial Action \& Waste Disposal Project (RAWD):
}

\section{ACCOMPLTSHMENTSA RAWD}

ERDF Transportation and Operations: On May 11, the ERDF transportation organization completed 4 million safe miles of waste hauling without an accident. This major milestone encompasses all remediation work since the first waste shipment was transported to ERDF in 1996.

During May, shipments totaling 55,540 metric tons (61,223 tons) of contaminated waste were transported to the ERDF. 415,913 metric tons $(458,468$ tons) have been received in $F Y 2000$ (6\% more than planned). To date, 2,142,890 metric tons (2,362,144 tons) of material have been received and placed in the disposal facility (1\% more than planned).

100 B/CArea Remedlation: $A$ baseline change proposal (BCP) requesting funding to finalize a procurement package for remediation of B/C pipelines was approved on May 16. An RFP is scheduled to be ready by August with procurement and subcontractor selection to be completed earty in Fr 2001. A start date for remedial action will be determined during the FY 2001 detailed work plan process.

100 D Ara Remediation: Excavation of the waste sites and pipelines in the 100 D Area is nearing completion. Shearing of the 1.5- and 1.7-meter (60-and 66-inch) diameter steel pipe was completed, and the reduced sections were sent to ERDF for disposal. Asbestos abatement of pipe joints was completed, and only miscellaneous deanup remains. Cutting of pipe with handheld torches was completed. Cleanup of pipe trenches progressed in preparation for analytical sampling. Concrete breaking was also completed.

The backfill subcontractor began mobilizing equipment at the site. Backfill of the 116-DR-1 and 2 trenches is scheduled to be completed the end of June. Approval to backfill the east/west portion of the north pipelines was received from the regulators on May 2. This approval also released all the stockpiled materials, associated with Group 2 (DR Area high priority), for use as backfill.

100 F Area Remedlation. Final grading for the 100 F Area queue, frisking tent, equipment laydown, and support areas was completed. Hauling of crushed rock began.

$100 \mathrm{H}$ Area Remediation: The baseline excavation of 116-H-17 Trench Overflow, 116-H-2 Disposal Trench, and 100-H-5 S/udge Bunial Pit were completed. All baseline excavations, except for the 100-H-24 Substation, are complete in the $100 \mathrm{H}$ Area. Two large plumes in the 116-H-1 Disposal Trench and 116-H-7 Retention Basin (BCPS were approved) will extend the schedule to August. The last section of 0.5-meter diameter (20-inch) steel pipe was removed and sent for disposal. Drilling of the deep vadose characterization borehole was also completed.

Lead contamination was detected in soil samples collected from the 1607-H-2 septic tank waste site in concentrations ranging from $8.2 \mathrm{mg} / \mathrm{kg}$ to $48.5 \mathrm{mg} / \mathrm{kg}$. These concentrations meet the Remedial Action Goal (RAG) for direct exposure (353 mg/kg). However, the soil RAGs for lead protection of groundwater and the Columbia River are at Hanford Site background levels $(10.2 \mathrm{mg} / \mathrm{kg})$. In the case of the $1607-\mathrm{H}-2$ site, with the present lead concentrations, the site fails the groundwater and river protection criteria. A test pit was dug and vertical profile samples were taken to quantify the depth of the elevated lead concentrations. 


\section{ENVIRONMENTAL MANAGEMENT PERFORMANCE REPORT ENVIRONMENTAL RESTORATION \\ JULY 2000}

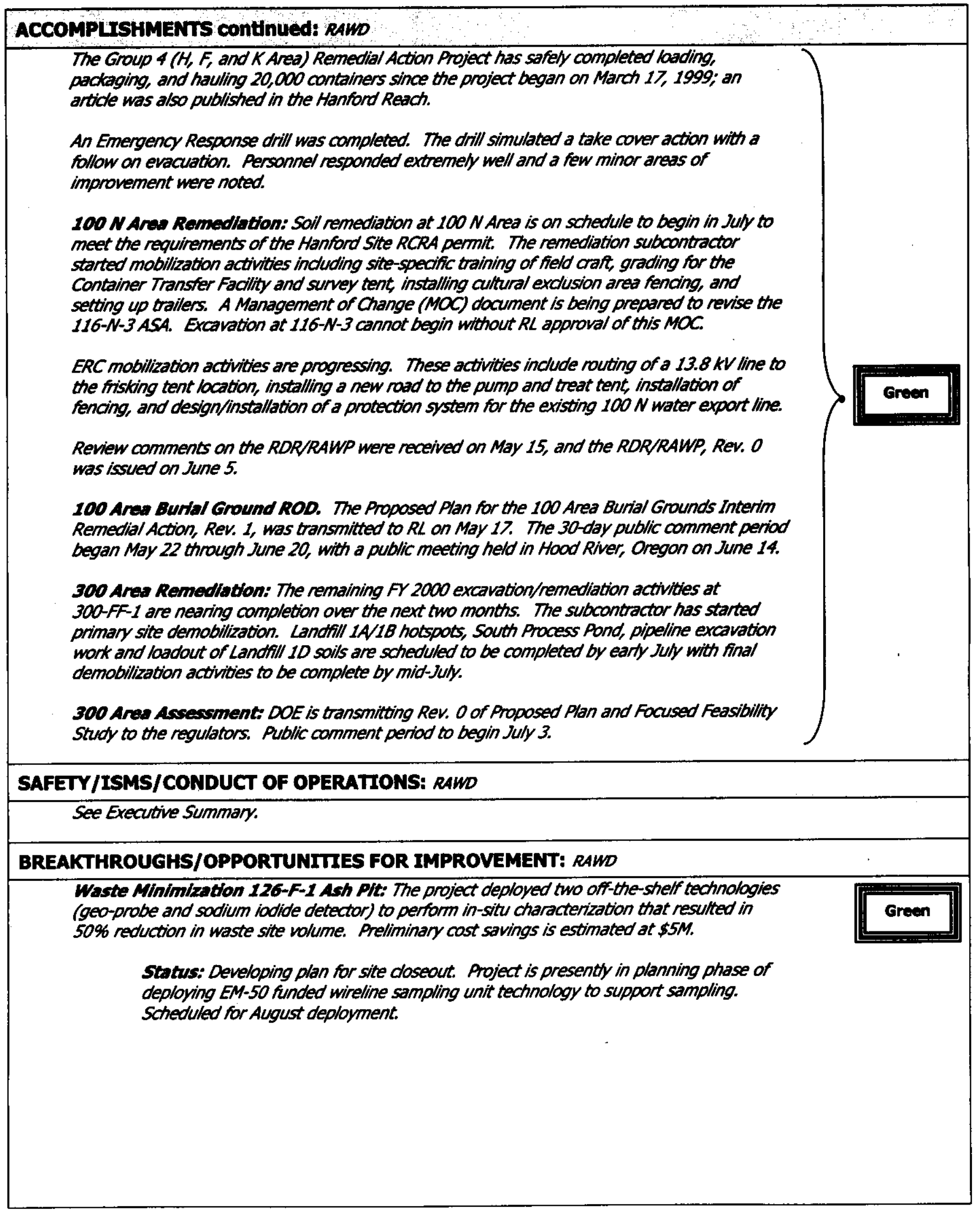




\section{ENVIRONMENTAL MANAGEMENT PERFORMANCE REPORT ENVIRONMENTAL RESTORATION \\ JULY 2000}

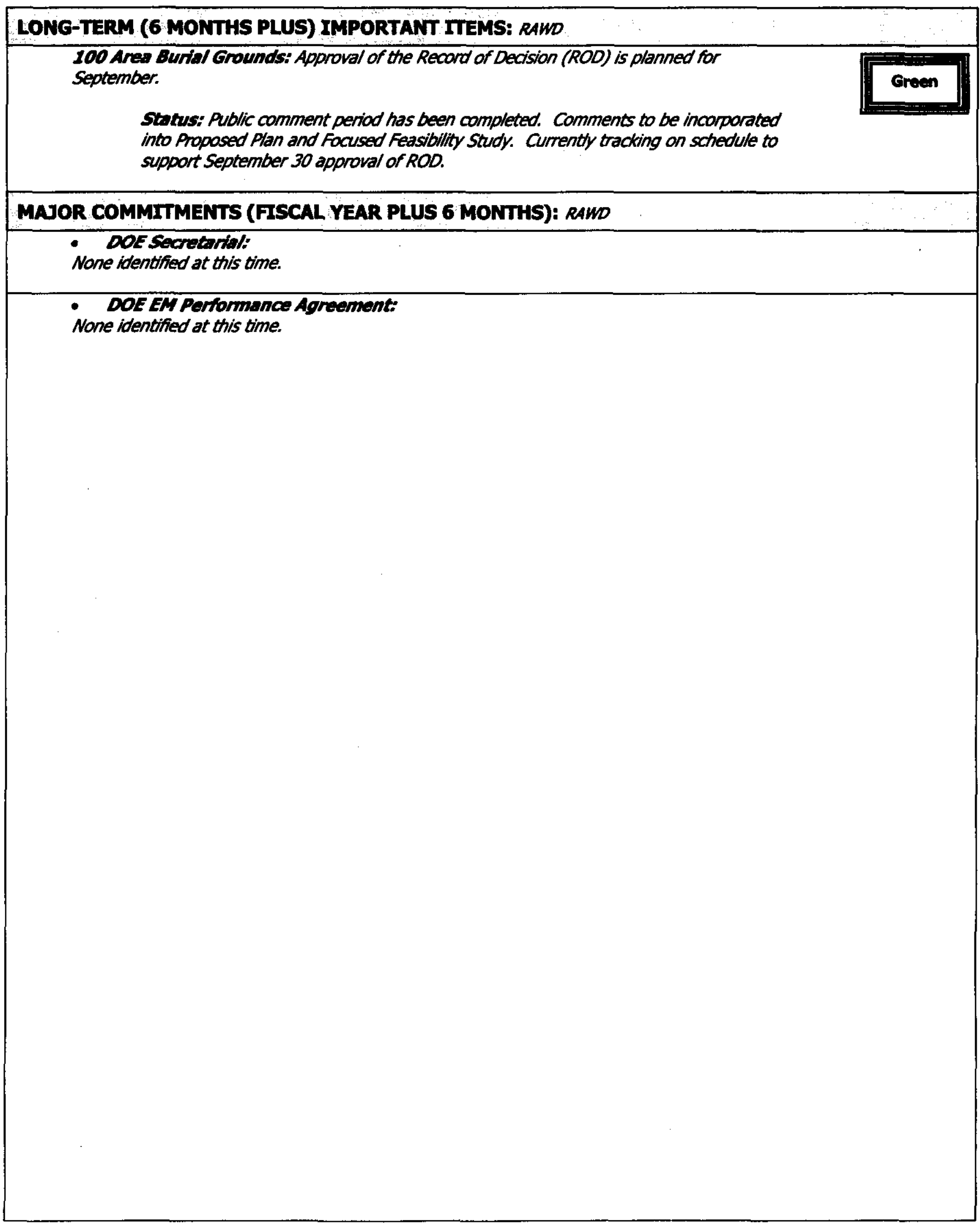




\section{ENVIRONMENTAL MANAGEMENT PERFORMANCE REPORT ENVIRONMENTAL RESTORATION \\ JULY 2000}

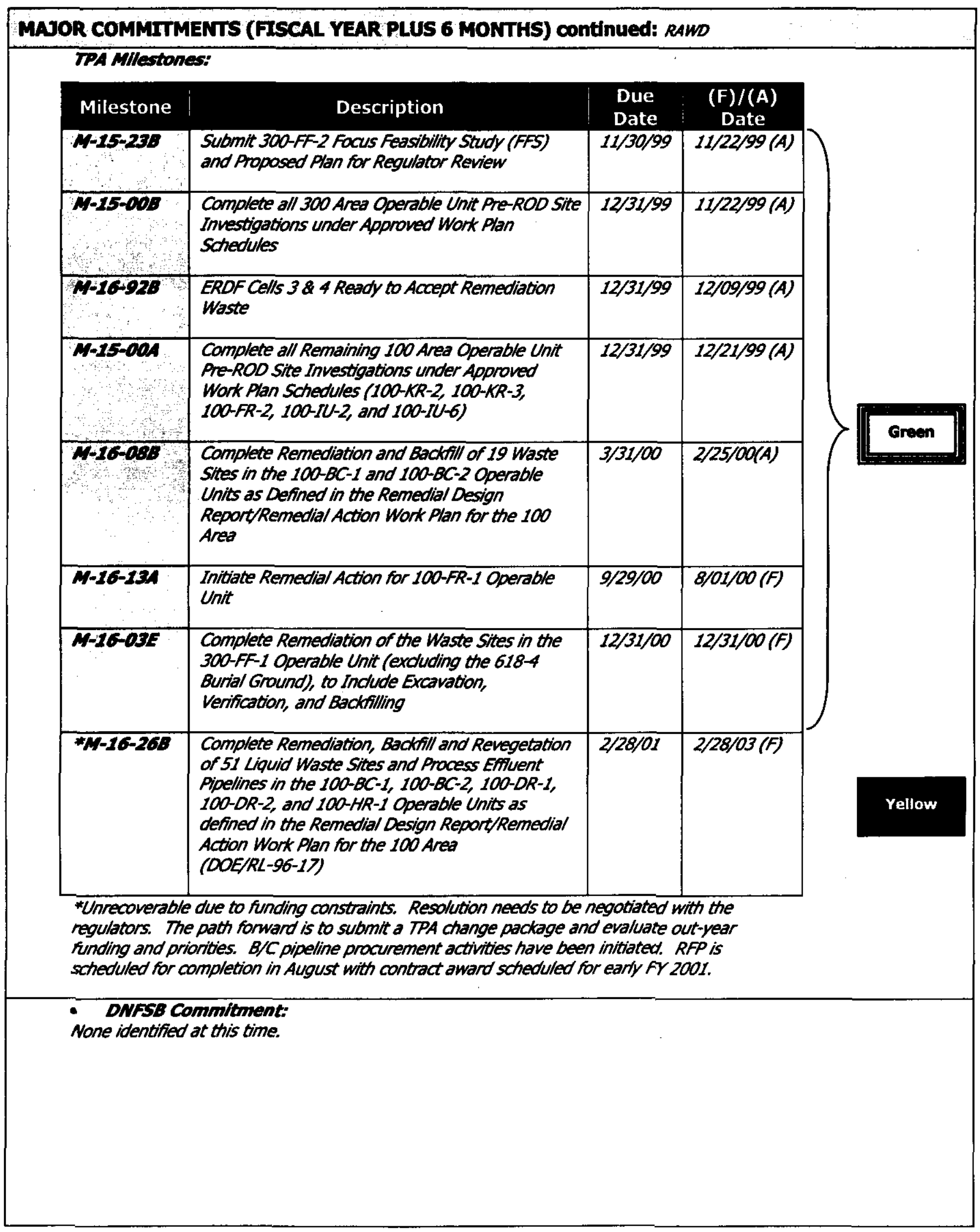




\section{ENVIRONMENTAL MANAGEMENT PERFORMANCE REPORT ENVIRONMENTAL RESTORATION \\ JULY 2000}

\section{PERFORMANCE OBJECTIVESI RAWD}

\begin{tabular}{|l|l|l|}
\hline \multicolumn{1}{|c|}{ Outcome } & Performance Indicator & \multicolumn{1}{|c|}{ Status } \\
\hline $\begin{array}{l}\text { Restors the R/ver } \\
\text { Corridor for Mulpho Uses }\end{array}$ & $\begin{array}{l}\text { 100/300 Area waste } \\
\text { excavation, disposa/ and } \\
\text { backfill/regrade. }\end{array}$ & $\begin{array}{l}\text { Baseline work is projected to } \\
\text { be completed per PI } \\
\text { requirements. }\end{array}$ \\
\hline
\end{tabular}

PERFORMANCE MEASURES: RAWD - (Rher and PAgteau)

\begin{tabular}{|c|c|c|c|c|c|}
\hline & $\begin{array}{l}\text { DWP } \\
\text { FYO0 }\end{array}$ & $\begin{array}{l}\text { FY00 Mgmt } \\
\text { Commitments }\end{array}$ & $\begin{array}{l}\text { Current Baseline } \\
\text { (Incl. Baseline } \\
\text { Changes) }\end{array}$ & $\begin{array}{l}\text { Forecast } \\
\text { For } \\
\text { FY00 }\end{array}$ & $\begin{array}{l}\text { Completed } \\
\text { YTD }\end{array}$ \\
\hline Waste stives & 24 & $41^{b}$ & 40 & 40 & 16 \\
\hline $\begin{array}{l}100 \text { Area } \\
\text { Buntol Ground } \\
\text { Asceovingentas }\end{array}$ & 0 & 46 & 47 & 47 & $47^{\circ}$ \\
\hline $\begin{array}{l}\text { 300-FF-2 } \\
\text { Ascesosmonts }\end{array}$ & 119 & 119 & 119 & 119 & $119^{\circ}$ \\
\hline $\begin{array}{l}\text { Other } \\
\text { Acseasments }\end{array}$ & 2 & 2 & 2 & 2 & 2 \\
\hline Tons & $389 K$ & $N / A$ & $631 K$ & $631 K$ & $458 K$ \\
\hline
\end{tabular}

Proposed Plan, Draft A submittal.

- Although soil remediation quantities have increased, the number of sites has been adjusted through baseline change control to allow for plume growth. 


\section{ENVIRONMENTAL MANAGEMENT PERFORMANCE REPORT ENVIRONMENTAL RESTORATION \\ JULY 2000}

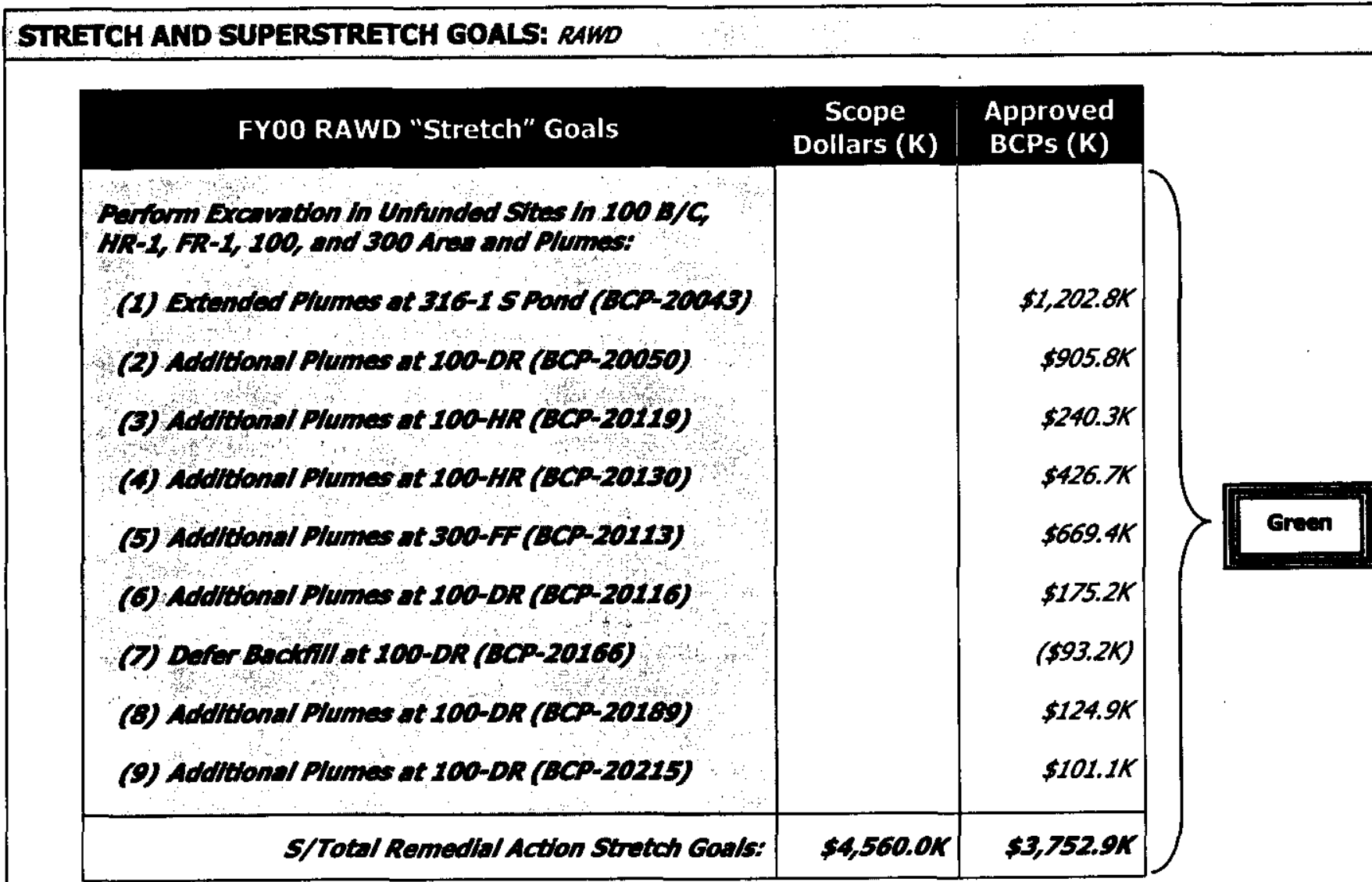

\begin{tabular}{|c|c|c|}
\hline FYOO RAWD "Superstretch" Goals & $\begin{array}{c}\text { Scope } \\
\text { Dollars (K) }\end{array}$ & $\begin{array}{l}\text { Approved } \\
\text { BCPs (K) }\end{array}$ \\
\hline $\begin{array}{l}\text { Complete Remediation of Co Sq. Mt. of Hanford Site: } \\
\text { (1) Complete Remediation of Hantord Townstis }\end{array}$ & $\$ 755.0 K$ & $\$ 0.0 \%$ \\
\hline $\begin{array}{l}\text { (2) Complete Remediation of JA Jones Ptt } \# 1 \text { and } \\
600-23(300-F F-2)\end{array}$ & $\$ 1,500.0 K$ & $\$ 0.0 K$ \\
\hline (3) Other Remedial Actions & $\$ 1,395.0 K$ & $\$ 0.0 K$ \\
\hline S/Total Remedial Action Superstretch Gasls: & $\$ 3,650.0 \mathrm{~K}$ & $\$ 0.0 K$ \\
\hline
\end{tabular}

*Status. Plan and estimate developed, current work efforts focusing on stretch activities at this time. 


\section{ENVIRONMENTAL MANAGEMENT PERFORMANCE REPORT ENVIRONMENTAL RESTORATION \\ JULY 2000}

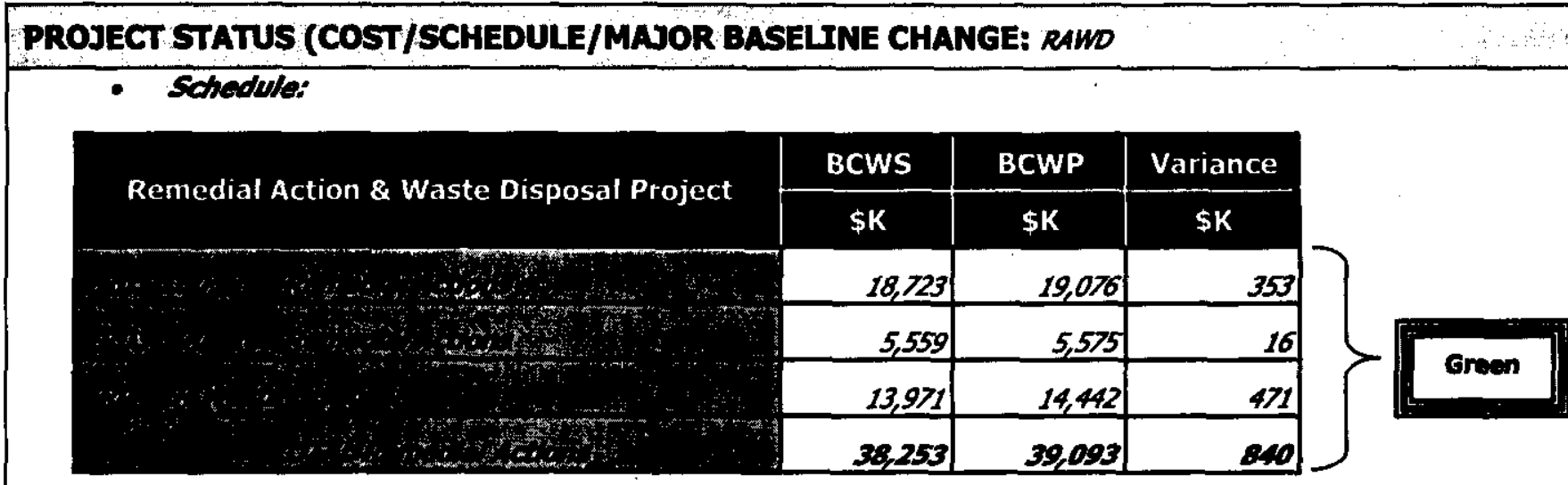

PRS-RRO1 - 100 Ane RemedidAction

Schedule Veriance $=+\$ 3534 ;+1.996$ [Last Month: $+\$ 503 ;+3.1 \%$ ]

Cunse: Ahead of schedule on 100-DR-1 pipeline excavation, 100-HR excavations, and NR-1 crib remediation design and site prep.

Rasolution: None required.

PBS-ERO3 - 300 Ares Remedial Action

Schedule Variance $=+\$ 16 \% ;+0.396$ [Last Month; $+\$ 292 K ;+5.9 \%$ ]

Cause: Excavation of Landfill $1 B$ is ahead of schedule; expect early completion.

Resolutton: None required; will complete ahead of schedule based on tonnage quantities.

PBS-EROS - Environmental Restoration Waste Dispasal

Schedule Variance $=+\$ 471 ;+3.4 \%$ [Last Month: $+\$ 264 K ;+2.2 \%$ ]

Cause: Ahead of schedule primarily due to 100-HR excavations and 300 Area excavations being ahead of schedule.

Resolution: None required.

\section{- Casto}

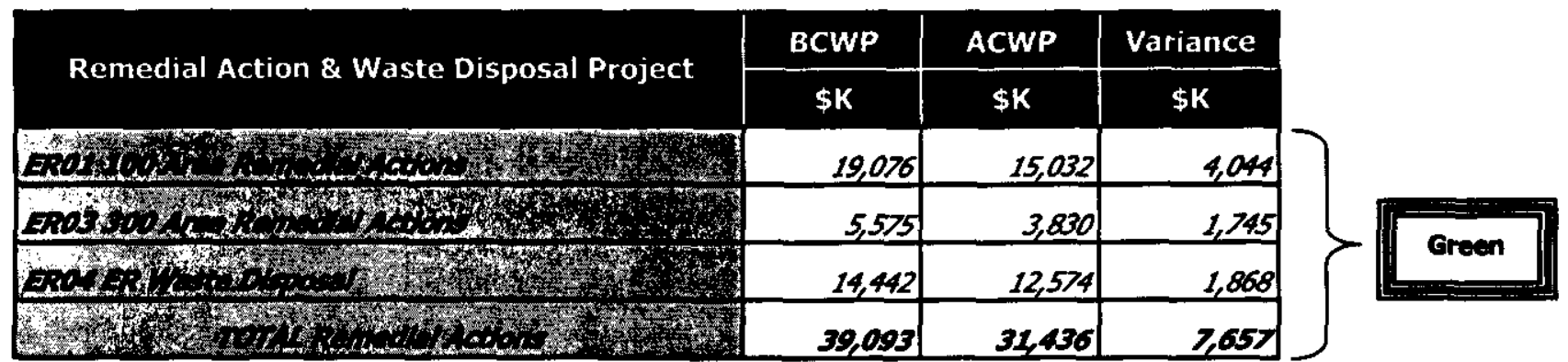

PRG-FRO1 - 100 Ares Remedtol Action

Cost Variance $=+\$ 4044 K ;+21.2 \%$ [Last Month: $+\$ 3441 K ;+20.4 \%$ ]

Causea Savings in DR-1 subcontract casts due to improving asbestos abatement process and fewer samples required; FR savings in site prep and staff reductions by re-allocating forces between $F \& H$ areas; labor savings on B/C backfill activities; waste minimization and drilling savings at HR near-river excavation sites. 


\section{ENVIRONMENTAL MANAGEMENT PERFORMANCE REPORT ENVIRONMENTAL RESTORATION \\ JULY 2000}

\section{PROJECT STATUS (COST/SCHEDULE/MAJOR BASELINE CHANGE CONHINUEd: RAWD}

Resolution: Savings will be used to perform other remediation work.

PRS-EROB - 300 Ares Remedtol Action

Cost Variance $=+\$ 1715 K_{;}+31.3 \%$ [Last Month: $+\$ 1837 \% ;+35.1 \%$ ]

Couse: Management and administrattive cost efficiencies at Landfills $1 A / 1 B$, and Fr 1999 accual reversal in South Process Pond remediation.

Resolution: Savings will be used to perform other remediation work.

PAS-ERO4 - Environmental Reatorablon Waste Disposal

Cost Variance $=\left[+\$ 1868 K_{;}+12.996\right]$ [Last Month: $\left.+\$ 1555 K_{i}+12.4 \%\right]$

Cause: ERDF cover design and construction doseout completed with fewer resources than planned; FY 1999 over accual.

Resolution: Savings will be used to perform other remediation work.

\section{REGULATORY ISSUES: RAWD}

300-FF-2: Work is ongoing to prepare decision documents for the public review period scheduled for July. Ecology has issues with the preliminary remediation goals (PRGS) being developed for 300-FF-2. EPA, who supports the PRGs, will be addressing issues with Ecology with support from RL.

Status: EPA and Ecology are in agreement on PRGs. Public comment scheduled to begin July 2.

M-16-26B: M-16-26B, Complete Remediation, Backfill, and Revegetation of 51 Liquid Waste Sites and Process Effuent Pipelines at $B / C, D R$, and $H R$, by February 28, 2001, will be missed due to lack of funding for 100 Area B/C pipelines and arsenic issue at $100 \mathrm{H}$.

Status: A resolution is required to be negotiated with the regulators. The path forward is to submit a TPA change package to the regulators for review and evaluate outyear funding and priorities. An RFP is scheduled to be ready by August with procurement and subcontractor selection to be completed early in FY 2001. A start date for remedial action will be determined during the Fr 2001 detailed work plan process.

M-16-26C: M-16-26C, Complete Remediation and Backfill of 10 Liquid Waste Sites and Process Effuent Pipelines in the 100-HR-1 Operable Unit, by May 31, 2001, will be missed due to unanticipated elevated arsenic levels encountered duning confirmation sampling and verification activities (lead arsenate pesticides were used on pre-Hanford agricutural areas).

Status: After completing additional arsenic sampling throughout the 100 Areas, Ecology has agreed to use the Washington state background value of $20 \mathrm{mg} / \mathrm{kg}$ for arsenic. A BCP was approved that addresses the scope change. A TPA change package will be initiated. 
ENVIRONMENTAL MANAGEMENT PERFORMANCE REPORT

ENVIRONMENTAL RESTORATION

JULY 2000

DOE-RLA HQ ISSUES/REQUESTS (not covered elsewhere): RAWD

None identfied at this time.

INTECRATION ACTMITIES: RAWD

CRDF: In support of Hantord Site partnering, draft waste shipping and receiving plans (WSRPs) have been prepared for the two initial waste streams expected from the Spent

Nudear Fuel (SNF) Project's K Basin dean out work. Initial delivery of waste from the SNF is tangeted for June 26. 


\section{ENVIRONMENTAL MANAGEMENT PERFORMANCE REPORT}

ENVIRONMENTAL RESTORATION

JULY 2000

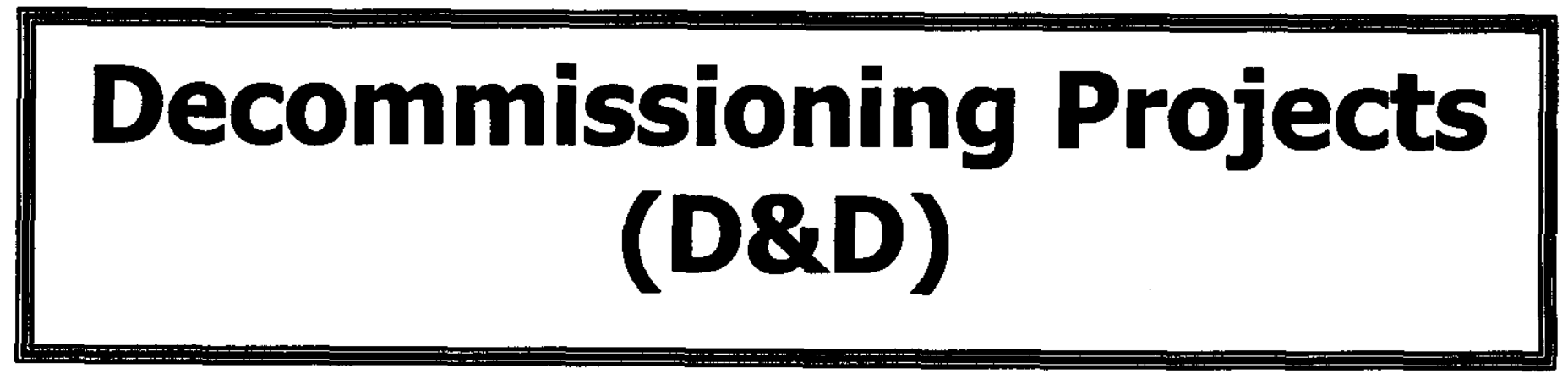




\title{
ENVIRONMENTAL MANAGEMENT PERFORMANCE REPORT ENVIRONMENTAL RESTORATION \\ JULY 2000
}

\section{SECTION B - RESTORING THE RIVER CORRIDOR}

\author{
Financial / Performance Measures data as of month-end May. \\ All other data as of June 22, 2000 (unless otherwise noted). \\ Decommissioning Projects (D\&D)
}

ACCOMPLISHMENTS: DQD

Fand DR Reactor ISS: The F and DR Removal Action Work Plan (RAWP) was revised to incorporate the $F$ Reactor five/ storage disposttion plan and air monitoring plan. The RAWP was forwarded to the regulators on May 4. F Reactor backfilling was initiated in the below-grade gas recirculation tunnel and plenum demolition areas in late May. Authorization for demolition of the F Reactor Fuel Storage Basin (FSB) was approved in April. Engineering and planning are underway, but are approximately two meeks behind schedule due to late start of activities. Full schedule recovery is expected. The water removal plan and the fiel transter plan are both nearing completion. A Memorandum of Understanding (MOU) was prepared with Fluor Hanford (FH) to obtain assistance in the event fuel fragments are found during the F Reactor FSB deanout.

At the DR Reactor, demolition and laadout was completed for the below-grade exhaust plenum and south gas recinculation tunnels. Concrete pourback forming was completed in the belowgrade valve pit, accumulator trench, and north gas tunnel area. Pourback forming is progressing in the south gas recirculation tunnel. Concrete pouring is scheduled for late June. A meeting was held with the regulators on May 17 to resolve the issue of higher than expected levels of carbon -14 , chromium +6 , and polychlorinated biphenyls in the DR FSB concrete. Agreement was reached that the contaminant concentrations were low enough and sufficiently immobile to allow the FSB foor slab to remain in place. Water removal and demolition preparation activities were completed in the transfer bay and FSB. Demolition of these two areas began on May 31.

$D$ and $H$ Reactor 1Ss: Room-by-room walkdowns and estimates in accessible areas were completed for both $D$ and H Reactors. The Waste Management Plan for the $D$ and H Reactors was approved. Task instructions and radiological work permits were completed in preparation for the biological cleanup of both reactors scheduled in June. Work progressed on the H Reactor Auditable Safety Analysis (ASA) document.

B Reactor: The draft B Reactor Safe Storage Phase II Feasibility Study is nearing completion. Additional engineering support was obtained to assist with the rough order of magnitude estimates for hazard identification that was outside the original scope. The additional hazand identification was requested by the regulators.

300 Area Acceleration Clasure Project: Decontemination and decommissioning (D\&D) quantity takeoffs, walkdowns, and estimates were completed in May. Draft sections of the a\&D Technical Volume were also completed.

233-5 Plutonium Concentration Facillty Decommissioning Project: Substantial work continued to be accomplished at the highly contaminated 233-S P/utonium Concentration Facility Decommissioning Project, including the following activities:

- Completed dry cleanup and gross decontamination of the process hood floor, and collected a total of 51 polyjars ( 0.5 liter in size) of loose material.

- Removed eight first-floor channel iron pieces from the process hood east face, and two fourth-foor PMMA panels from the process hood front face. 


\section{ENVIRONMENTAL MANAGEMENT PERFORMANCE REPORT ENVIRONMENTAL RESTORATION

\author{
JULY 2000
}

\begin{tabular}{|c|c|}
\hline ACCOMPLISHMENTS continued: DQD & \\
\hline $\begin{array}{l}\text { - Completed core drilling of the third } 30.5 \text {-centimeter (12-inch) ventilation hole on the south } \\
\text { wall of the loadout hood room. Installed two exhausters to support localized exhaust. } \\
\text { - Completed de-energized electrical verifications, conduit cutting, selected equipment } \\
\text { removal, and mockup training in preparation for selected grating removal. } \\
\text { - Shipped } 28 \text { meters (92 feet) of supply duct to ERDF. }\end{array}$ & Green \\
\hline SAFETY/ISMS/CONDUCT OF OPERATIONS: DQD & \\
\hline $\begin{array}{l}\text { Contamination detected under manufactured beft loops of Powered Air Purrifying Respirators } \\
\text { (PAPR). } \\
\text { Stutuss The immediate actions for PAPR beft loop contamination problems that } \\
\text { onginated at 233-S was to allow workers to use the manufactured belt loops or create } \\
\text { a temporary belt loop out of duct tape. Radiological Control personnel now } \\
\text { disassemble the manufacturer's belt loops for survey to ensure there is no } \\
\text { contamination in this previously inaccessible area. Corrective actions have not vet } \\
\text { been determined. BHI is currently performing a formal root cause analysis (RCA) on } \\
\text { the issues of contaminated PAPR units and procedure non-compliance. Upon } \\
\text { completion, the conclusions will be distributed to organizations that would have } \\
\text { responsibility for determining the best corrective action. }\end{array}$ & Yellow \\
\hline
\end{tabular}

\section{BREAKTHROUGHS/OPPORTUNITIES FOR IMPROVEMENT: OSD}

None identified at this time.

\section{LONG-TERM (6 MONTHS PLUS) IMPORTANT ITEMS: DSD}

None identified at this time.

MAJOR COMMITMENTS (FISCAL YEAR PLUS 6 MONTHS): DQD

- DOE Secretantal:

None identified at this time.

- DOE EM Performance Agreement:

2248: Complete draft Engineering evaluation/cost analysis (EE/CA) and submit to regulators -

July 2000. Complete draft SAP and submit to regulators - September 2000.

Status: Assessment activities in $224 B$ in support of decommissioning have ceased. A

$B C P$ to close out the remainder of the $224 B$ activities in FY 2000 has been approved.

- TPA Millestones:

\begin{tabular}{|l|l|l|l|}
\hline Milestone & \multicolumn{1}{|c|}{ Description } & Due Date & $\begin{array}{c}\text { (F)/(A) } \\
\text { Date }\end{array}$ \\
\hline M-93-05 & $\begin{array}{l}\text { Issue B Reactor Phase II Feasibility Study } \\
\text { Engineering Design Report for Public Comment }\end{array}$ & $6 / 30 / 00$ & $6 / 30 / 00$ (F) \\
\hline
\end{tabular}

(5) MAJOR COMMITMENTS (FISCAL YEAR PLUS 6 MONTHS) continued: D\&D

- DNFSB Commitment:

None identified at this time. 


\section{ENVIRONMENTAL MANAGEMENT PERFORMANCE REPORT ENVIRONMENTAL RESTORATION \\ JULY 2000}

\begin{tabular}{|c|c|c|c|}
\hline \multicolumn{4}{|c|}{ PERFORMANCE OBJECTIVES: DSD } \\
\hline Outcome & Performance Indicator & Status & \\
\hline $\begin{array}{l}\text { Rostore the R/ver } \\
\text { Connldor for Multplo uses }\end{array}$ & $\begin{array}{l}\text { Reactor ISS and preparation of } \\
\text { facilities for decommissioning. }\end{array}$ & $\begin{array}{l}\text { Baseline reactor ISS work } \\
\text { is projected to be } \\
\text { completed per PI } \\
\text { requirements. }\end{array}$ & \\
\hline \multirow{2}{*}{ 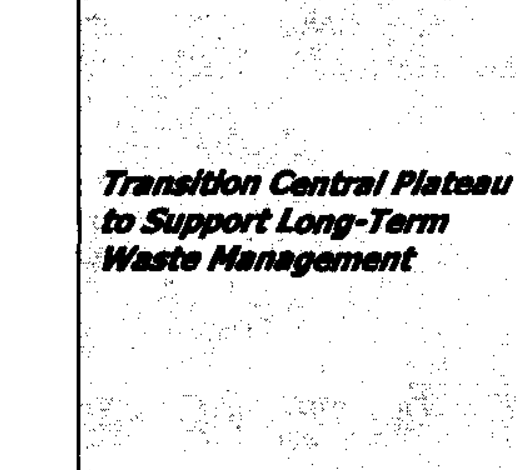 } & $\begin{array}{l}\text { Maintain facilities until D\&D } \\
\text { (233-S). }\end{array}$ & $\begin{array}{l}\text { Fr } 2000 \text { work resequenced } \\
\text { via BCP-20141, approved } \\
\text { March } 14,2000 \text {. New } \\
\text { pertormance indicators } \\
\text { drafted and submitted for } \\
\text { approval. }\end{array}$ & Green \\
\hline & $\begin{array}{l}\text { Maintain facilities until D\&D } \\
\text { (224B). }\end{array}$ & $\begin{array}{l}\text { BCP-20224 has been } \\
\text { approved and } \\
\text { recommends deletion of } \\
\text { the performance measure. }\end{array}$ & \\
\hline
\end{tabular}

\section{PERFORMANCE MEASURES: DRD}

\begin{tabular}{|l|c|c|c|c|c|}
\hline & $\begin{array}{c}\text { DWP } \\
\text { FY00 }\end{array}$ & $\begin{array}{c}\text { FY00 Mgmt. } \\
\text { Commitments }\end{array}$ & $\begin{array}{c}\text { Current Baseline } \\
\text { (Incl. Baseline } \\
\text { Changes) }\end{array}$ & $\begin{array}{c}\text { Forecast } \\
\text { For } \\
\text { FY00 }\end{array}$ & $\begin{array}{c}\text { Completed } \\
\text { YTD }\end{array}$ \\
\hline Facllitios & 0 & 0 & $4^{b}$ & $4^{b}$ & $3^{c}$ \\
\hline
\end{tabular}

${ }^{b} 116-D, 116-D R, 119-D R$ and $108-F$

C 116-D, 116-DR, 119-DR (108-F Final Report scheduled for 9/00)

\section{STRETCH AND SUPERSTRETCH GOALS: DSD}

\begin{tabular}{|c|c|c|c|}
\hline FYOO D\&D "Superstretch" Goals & $\begin{array}{c}\text { Scope Dollars } \\
\text { (K) }\end{array}$ & $\begin{array}{l}\text { Approved } \\
\text { BCPs (K) }\end{array}$ & \\
\hline $\begin{array}{l}\text { Continue F Raactor Interim Sife Storage (ISSS) } \\
\text { (BCP-20151) }\end{array}$ & $\$ 2,000.0 K$ & $\$ 1,490.8 K$ & \\
\hline $\begin{array}{l}\text { *Publlc Acaess to Manford Townsite and B } \\
\text { Rasctor }\end{array}$ & $\$ 750.0 K$ & $\$ 0.0 K$ & Green \\
\hline S/Total DSD Superstretch Gos/s: & $\$ 2,750.0 \mathrm{~K}$ & $\$ 1,490.8 K$ & \\
\hline
\end{tabular}

*Status: Requires funding support outside of ER to execute Superstretch. 


\section{ENVIRONMENTAL MANAGEMENT PERFORMANCE REPORT ENVIRONMENTAL RESTORATION \\ JULY 2000}

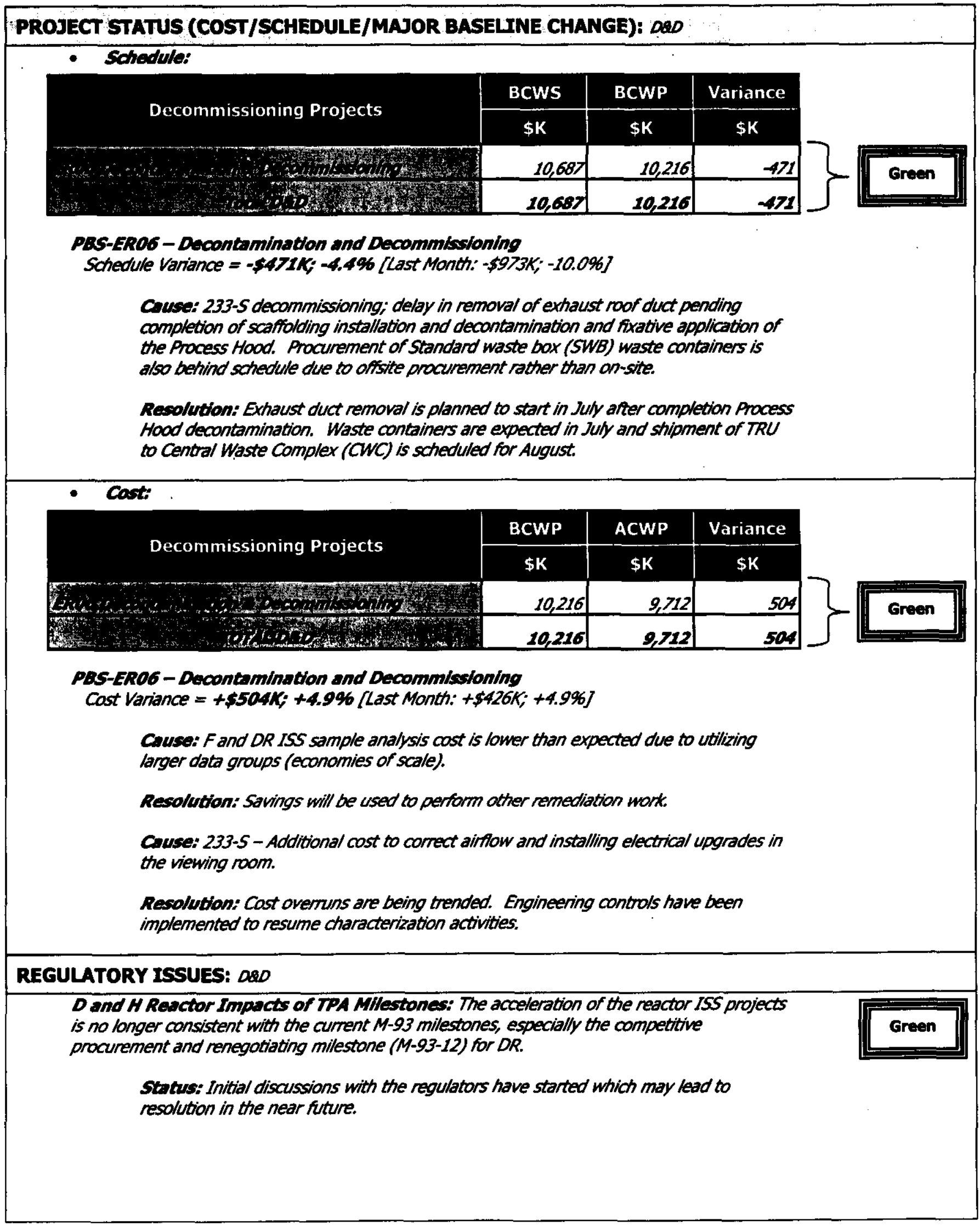




\title{
ENVIRONMENTAL MANAGEMENT PERFORMANCE REPORT ENVIRONMENTAL RESTORATION \\ JULY 2000
}

\section{REGULATORY ISSUES continued: $\triangle 2 D$}

DR Ranctor Fuel Storage Besin (FSEB): Analytic results for the DR Reactor FSB indicate a potential concem with chromium +6 , carbon -14 , and polychlorinated biphenyl levels in the concrete floor of the basin.

Status: EPA and Ecology have agreed that the remaining concentrations are acceptable and protective of the environment, and the basin need only be removed to the minus 15-feet level per the oniginal plan.

$D$ and $H$ Reactor Engineening Evaluation/Cast Analysis (EE/CA): The D and H Reactor EE/CA schedule required regulator reviews to be completed by April 19 to meet established Detalled Work Plan (DWP) goals. The EE/CA was completed in March.

Status: EPA stated that it wants to address the TPA reactor milestones before approving an action memorandum for $D$ and $H$ Reactors. EPA indicated that the cost for two reactors exceeded the cost threshold, and therefore would require review by the EPA Remedy Review Board. In order to expedite review and not exceed the cost criteria, a separate EE/CA for each reactor will be transmitted to $R L$ and the regulators on June 15. ER will continue to work with EPA and Ecology to ensure an action memorandum can be issued by the end of FY 2000.

Demolition Equipment: Demolition equipment (trackhoe excavators and shuttle truck) breakdowns continue to cause demolition schedule delays.

Stutus: Mechanics continue to repair the equipment as quickly as possible. Impact sheets are being completed to track the delays. Problems/impacts were presented to RMT. Field support developed an equipment priority list and was directed to prepare a procurement plan for a new excavator.

EXTERNAL ISSUES (1.e. HAB, Congress, etc.): DSD None identified at this time.

DOE-RL \& HQ ISSUES/REQUESTS (not covered elsewhere): 080 None identified at this time.

\section{INTEGRATION ACTMVITES: DSD}

\author{
None identified at this time.
}




\section{Program Management and Support (PM\&S)}




\title{
ENVIRONMENTAL MANAGEMENT PERFORMANCE REPORT ENVIRONMENTAL RESTORATION \\ JULY 2000
}

\section{SECTION B - RESTORING THE RIVER CORRIDOR}

\author{
Financial / Performance Measures data as of month-end May. \\ All other data as of June 22, 2000 (unless otherwise noted). \\ Program Management \& Support (PM\&S)
}

ACCOMPLTSHMENTS: AMES

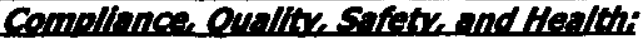

Compllance and Quallty Programs: A report was completed that will be used in an independent assessment of the corrective action plan submitted to EPA and Ecology in response to a Notice of Violation. The independent assessment was initiated by BHI management to verify that the corrective action plan had been implemented.

Five opportunities for improvement and 28 concerns from the RL Integrated Safety Management Survey Verification Report were entered into the ERC Corrective Action Tracking System.

Safoty and Hawlth: A series of briefings were presented to ERC Projects personnel concerning the timeliness of event notifications to line management. Event information did not reach line management soon enough to make timely response decisions in several recent events. The briefings were conducted at two locations in 200 West and one location at $100 \mathrm{~N}$ and 1000 Areas, and induded response drivers, responsibilities, and consequences.

\section{Proorrm and Peoiect syoporti}

Publication \& Graphics (P\&CS): Two meetings were held at $3350 \mathrm{GWW}$ to host an RLsponsored Site Services Review Team that consisted of representatives from RL, FH, HEHF, PNNL, and BHI. The purpose of the meetings was to provide the team with information on BHI processes for providing support services in the areas of records management, printing, duplicating, photographic services, and graphic design. A tour of a local vendor's offsite duplicating facility was included as one part of these meetings.

Procurement and Property Management: The FY 1999 Procurement DOE-Complex Balanced Score Card (BSC) results indicated that BHI received the highest score (tied) in the DOE complex in four of the eleven categories tracked by DOE. The four categories were Customer Satisfaction, Effective Internal Controls, Employee Alignment, and Information Avaliability. This is the second year in a row that BHI received the highest score in four categories and includes a repeat performance in the "Customer Satisfaction" and "Information Avallability" categories. This is especially significant since the number of major DOE facility contractors participating in the BSC process has almost doubled and now includes almost all of the major DOE complex contractors. In addition, for all of the remaining categories that $B H I$ participated in, BHI's score was significantly above the DOE complex average.

\section{Encineserine \& Technologi:}

Technology Applications: The Technology Applications group hosted a visit by the National Research Council Committee on Deactivation and Decommissioning Research Needs. The committee toured the Hanford Site and attended presentations on D\&D Projects.

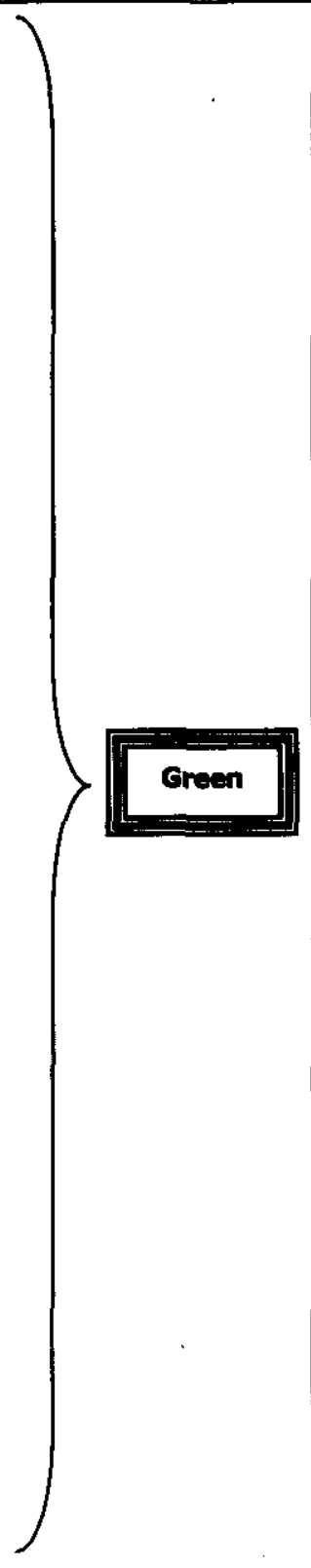




\section{ENVIRONMENTAL MANAGEMENT PERFORMANCE REPORT ENVIRONMENTAL RESTORATION JULY 2000}

\section{ACCOMPLISHMENTS continued: PMAS}

Environmental Technologles: A review was completed of the first quarter environmental sample disposition records. 934 samples were collected with no chronic or systematic problems associated with the sampling and analysis services identified.

45 miscellaneous radiologically posted areas were added into the Waste Information Data Systems (WDS) as new waste sites, and a walkdown of the remaining 1100 Area sites was performed with EPA and RL, whereby six sites were approved as "rejected".

In May, an implementation plan was developed for ensuring compliance with the new DOE Order 435.1. The ER plan was also incorporated into the Hanford site-wide implementation plan.

ER was recognized by the Secretary of Energy with a Certificate of Appreciation for contributions to DOE's mission to prevent pollution in operations, processes, and programs.

Automution Tochnology: Effectively responded to VBS. Loveletter.A (Lovebug) computer virus attack. The vinus was immediately discovered at 6:30 a.m. on May 4 and all e-mail senvices were stutdown. Throughout the day, Automation Technology worked diligently to update the ERC vinus protection software and vins definition files. All file servers were scanned and e-mail service was restored by 7:30 p.m. All other BLAN services were available throughout the day.

Established connectivity to the online Materia/ Safety Data Sheet (MSDS) between the Bectite/ Local Area Network and the Hanford Local Area Network. Real-time access to this data will reduce the time it takes to process shipping documents pertaining to chemicals.

\section{Plonninge Controlst}

Starf/Baseline: Several documents and worksheets were created in support of the FY 20012003 DWP development. Items induded the P3/Parade guidance document, shells containing resource rates, and cost estimating worksheets. The FY 2001-2003 DWP Development Process Guidance document was also issued.

The ERC FY 2000 Mid-Year Review Report was completed. A presentation was made to Hanford RL management and HQ personne/ on May 8-9.

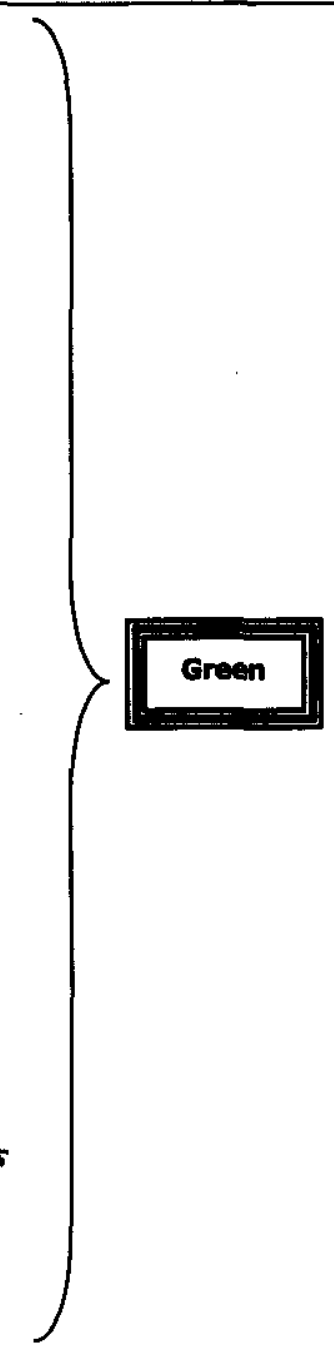

\section{SAFETY/ISMS/CONDUCT OF OPERATIONS: PMBS}

See Executive Summary.

BREAKTHROUGHS/OPPORTUNITIES FOR IMPROVMENT: PMBS

None identified at this time.

LONG-TERM (6 MONTHS PLUS) IMPORTANT ITEMS: PMBS

None identified at this time.

\section{MAJOR COMMITMENTS (FISCAL YEAR PLUS 6 MONTHS): PMBS}

- (5A) DOE Secretorial:

None identified at this time.

- (5B) DOE EM Performance Agreement:

None identified at this time. 


\section{ENVIRONMENTAL MANAGEMENT PERFORMANCE REPORT ENVIRONMENTAL RESTORATION \\ JULY 2000}

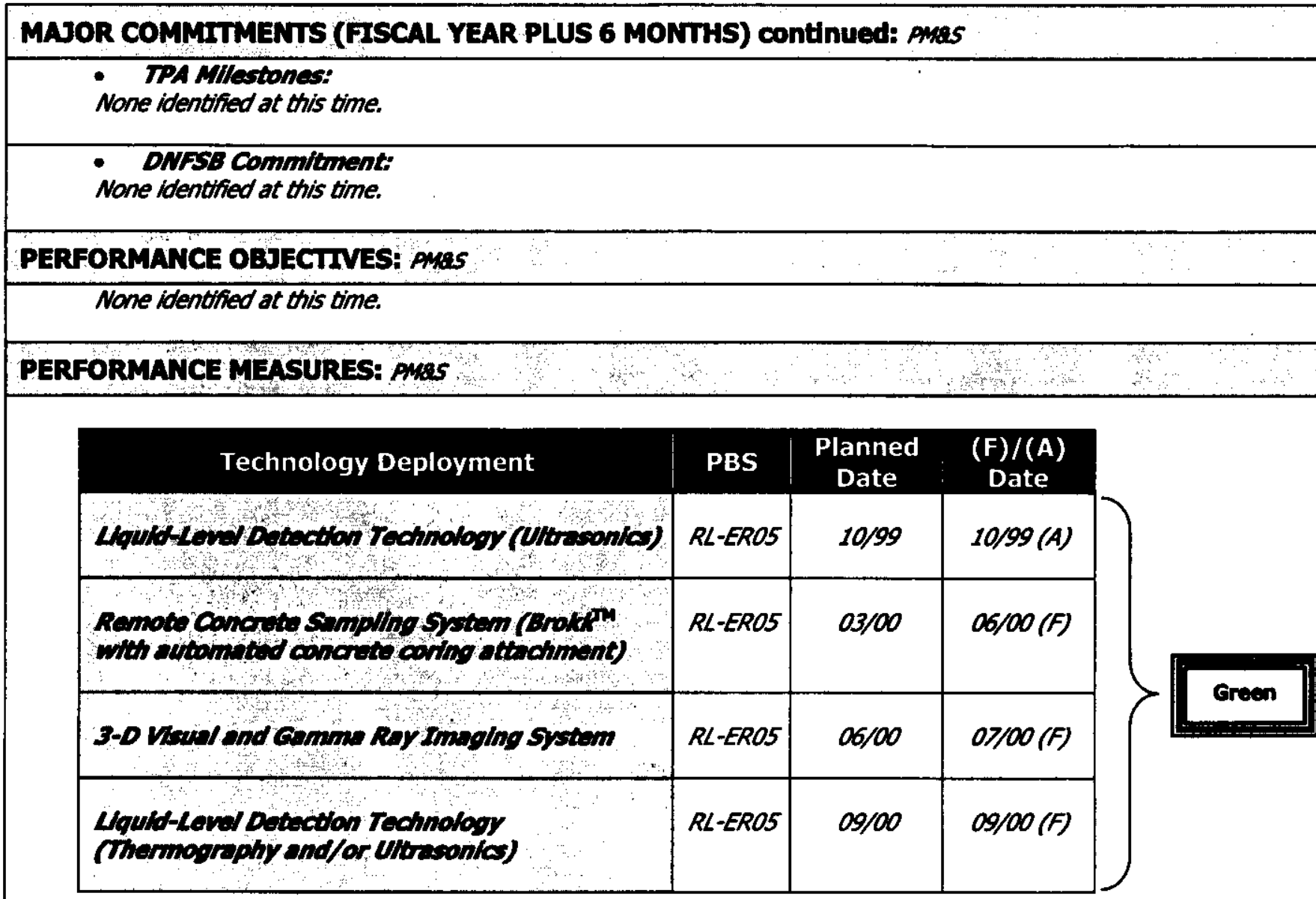

\section{STRETCH AND SUPERSTRETCH GOALS: PMBS}

None identified at this time.

\section{PROJECT STATUS (COST/SCHEDULE/MAJOR BASELINE CHANGE): PMRS}

\section{- Schodulet}

\begin{tabular}{|c|c|c|c|c|}
\hline \multirow{2}{*}{ Program Management \& Support } & BCWS & BCWP & Variance & \\
\hline & $\$ K$ & $\$ K$ & $\$ K$ & \\
\hline 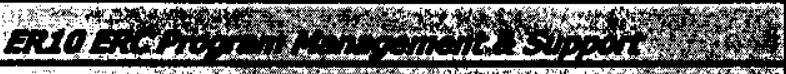 & 14,652 & 14,483 & -169 & \\
\hline 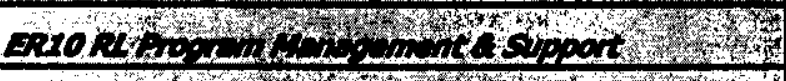 & 4,591 & 3,172 & $-1,419$ & Green \\
\hline 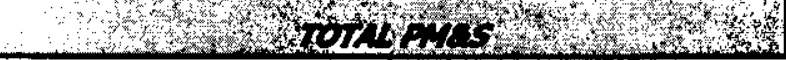 & 19,243 & 17,655 & $-1,580$ & \\
\hline
\end{tabular}

PBS-ER10 - Program Management and Support

Schedule Variance $=-\$ 1588 K ;-8.3 \%$ [Last Month: $-\$ 1294 K ;-7.7 \%$ ]

Causer Late billing on site-wide assessments.

Resolution: RL is discussing billing/timing with other site contractors. 


\section{ENVIRONMENTAL MANAGEMENT PERFORMANCE REPORT ENVIRONMENTAL RESTORATION \\ JULY 2000}

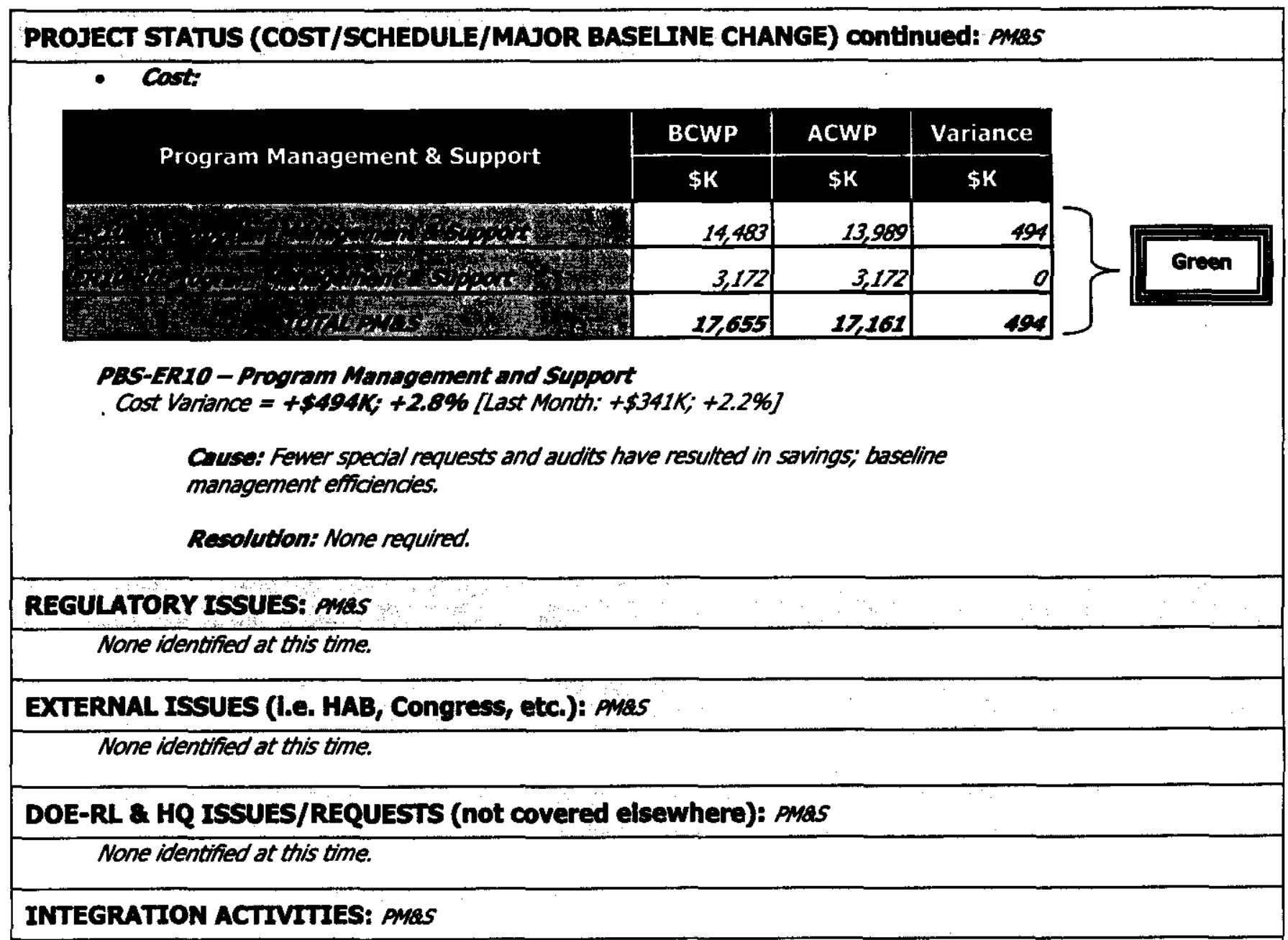

None identified at this time. 


\section{Richland Operations Office Environmental Restoration \\ Environmental Management Performance Report}

\section{Section C - Central Plateau Infohinctioll}

July 2000

Transition the Central Plateau

- Groundwater / Vadose Zone Integration Project

- Surveillance / Maintenance \& Transition Projects

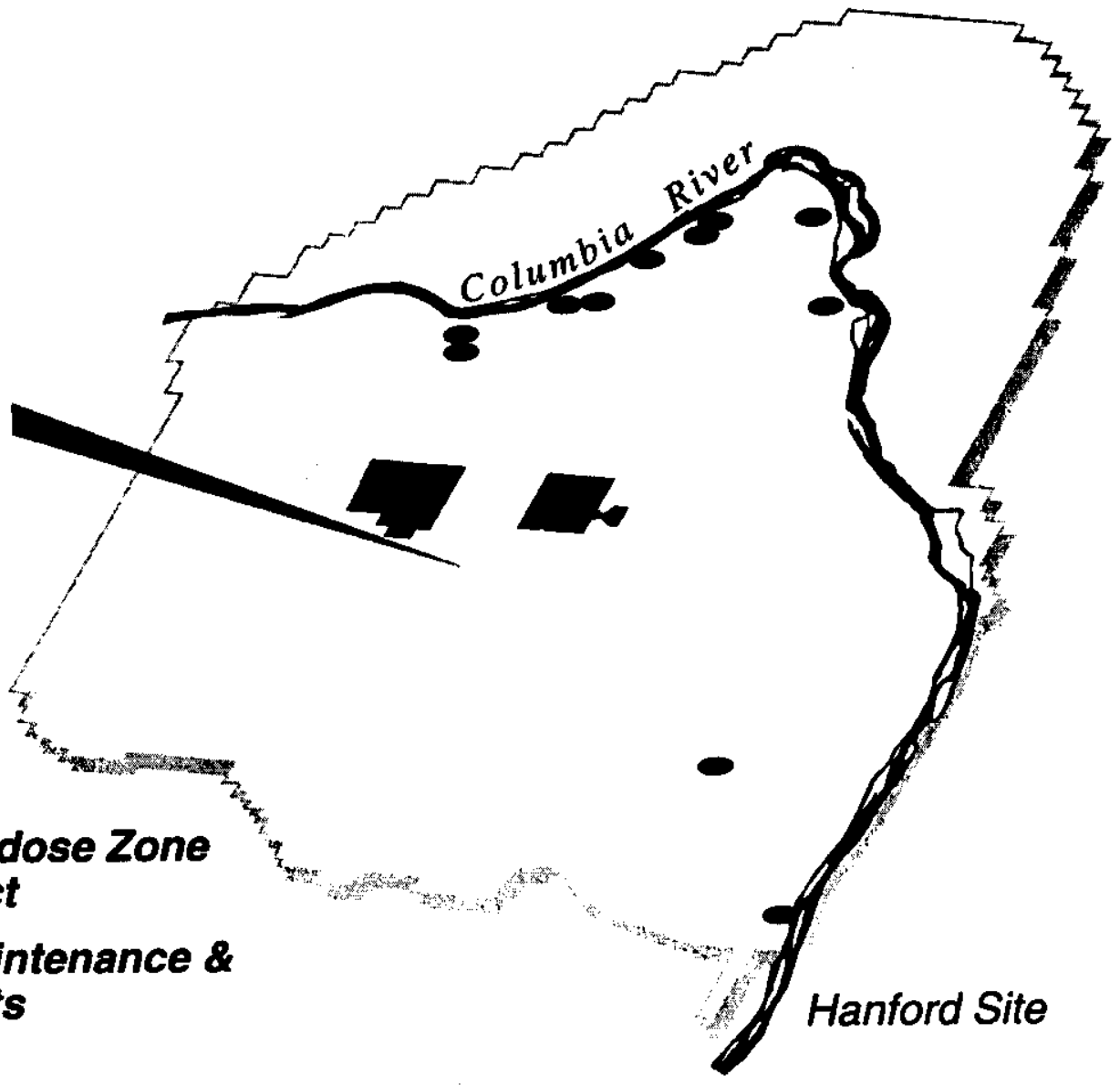

Focused on Progress...

Focused on Outcomes! 


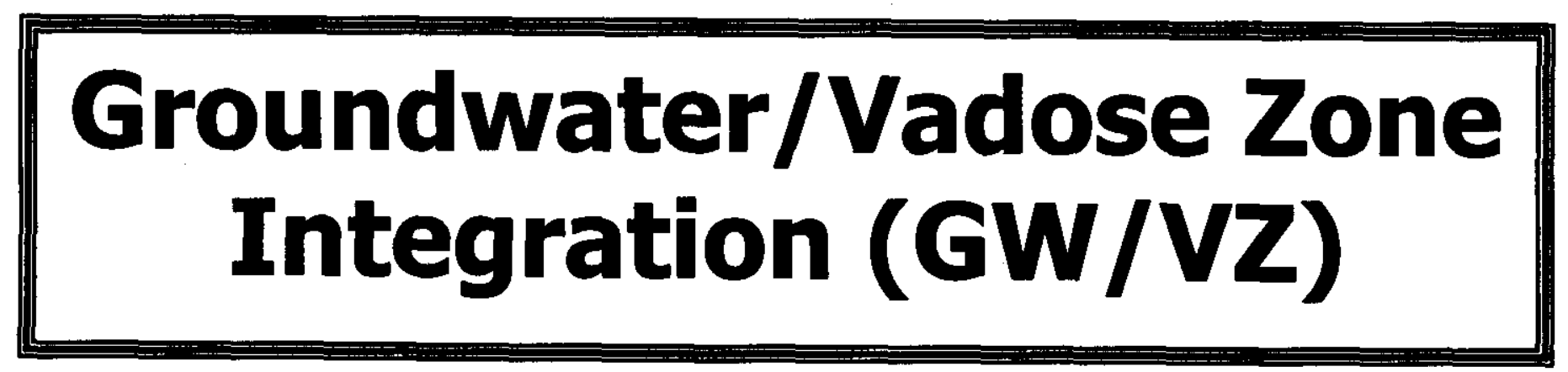




\title{
SECTION C - TRANSITIONING THE CENTRAL PLATEAU
}

\author{
Financial / Performance Measures data as of month-end May. \\ All other data as of June 22, 2000 (unless otherwise noted). \\ Groundwater/Vadose Zone Integration (GW/VZ):
}

ACCOMPLITSHMENTS: OWNZ

GWVR Imtearation Proileat:

General Project Activitlas: Project briefings were conducted for HQ management and members of Senator Wyden's staff in Washington D.C. The expert panel meeting was conducted in May. The Idaho National Engineering and Environmental Laboratory's (INEEL) complex-wide Roadmapping workshop was also attended.

Public Involvement: The Semi-Annual Groundwater/Nadose Zone Report to Congress was completed on May 31. Completion of this report satisfied a FY 2000 management commitment milestone. Meetings were held with the Nez Perce Tribe and the regulators to discuss Fr 2001-2003 Detalled Work Plan (DWP) assumptions and the SAC.

Sclence and Tectmology: The S\&T Raadmap Rev. 1 was completed. This revision to the document incorporated revisions to Inventory, Vadose Zone, Groundwater, River technical elements, and added the Risk element in the WMA S-SX field investigation report. Additionally, the field test site was prepared for the Vadose Zone Transport Field Study, induding installation of monitoring equipment.

System Assessment Capablilty: Draft A of the SAC Rev. 0, Assessment Description, Requirements, Software Design and Test Plan was completed. RL is reviewing the document.

\section{Goundwater Management:}

In SItu REDOX Manipulation Project: The design for the ISRM evaporation pond waS completed, and the construction bid package was issued for bid. The Remedial Design Report/Removal Action Work Plan (RDR/RAWP) was issued to RL and Ecology for review and concurrence.

Long-Term Groundwater Monitoring: Preparations were made for kick-off workshops in the planning of future RCRA monitoring wells. To date, discussions have focused on proposed Liquid Effuent Retention Facility (LERF) monitoring afternatives. A statistical appraach for the 300 Area Process Trenches RCRA monitoring was addressed in a letter to Ecology in response to comments received.

Tritium Investigation: Draft A of the Data Quality Objective Report was finalized for regulator review. This report will provide the basis for the Phase II Tritium Investigation scope.

\section{Ane:Araciment:}

Review comments were received from the regulators for the 200-CW-5 U Pond/Z Ditches Cooling Water Waste Group RI/FS Work Plan.

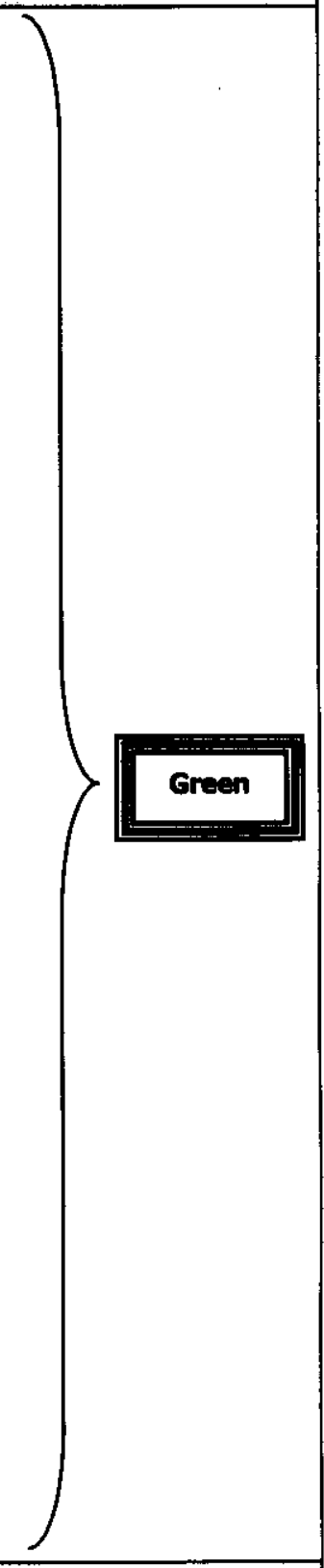

SAFETY/ISMS/CONDUCT OF OPERATIONS: GWNZ

See Executive Summary. 


\title{
ENVIRONMENTAL MANAGEMENT PERFORMANCE REPORT ENVIRONMENTAL RESTORATION \\ JULY 2000
}

\author{
BREAKTHROUGHS/OPPORTUNITIES FOR IMPROVEMENT: GWNZ \\ None identified at this time.

\section{LONG-TERM (6 MONTHS PLUS) IMPORTANT ITEMS: GWNZ} \\ None identified at this time.

\section{MAJOR COMMITMENTS (FISCAL YEAR PLUS 6 MONTHS): GWNZ} \\ - DOE Secrotarlali \\ Transmit Update of the Vadose Zone Science and Tectinology Roadmap (PBS VZO1) due April \\ 30.
}

Status: Complete. Draft was transmitted to RL on April 28.

Install Wells and Initiate Injection of the Barrier for Phase I of the In Situ REDOX Groundwater Remediation (PBS EROB) due September 30.

Status: Forecasted for completion by September 30. (16-well installation was completed on April 24).

- Ecology has stated their concurrence with the activities described in the Revision 0, Remedial Design Report / Remedial Action Work Plan (DOE/RL-99-51, Rev. 0, May 2000).

- The evaporation pond contract was awarded in early June. The contractor will be mobilizing mid-June to construct the evaporation pond used for well extraction waste management activities.

- Well injections are forecasted to begin sometime in July, to be completed in September.

Complete the Semi-Annual Groundwater/Nadose Zone Report (December 1999 - March 2000) (PBS VZO1) due May 31.

Status: Complete. Final document was transmitted to RL on May 31.

- DOE EM Performance Agroement:

None identified at this time. 


\section{ENVIRONMENTAL MANAGEMENT PERFORMANCE REPORT ENVIRONMENTAL RESTORATION \\ JULY 2000}

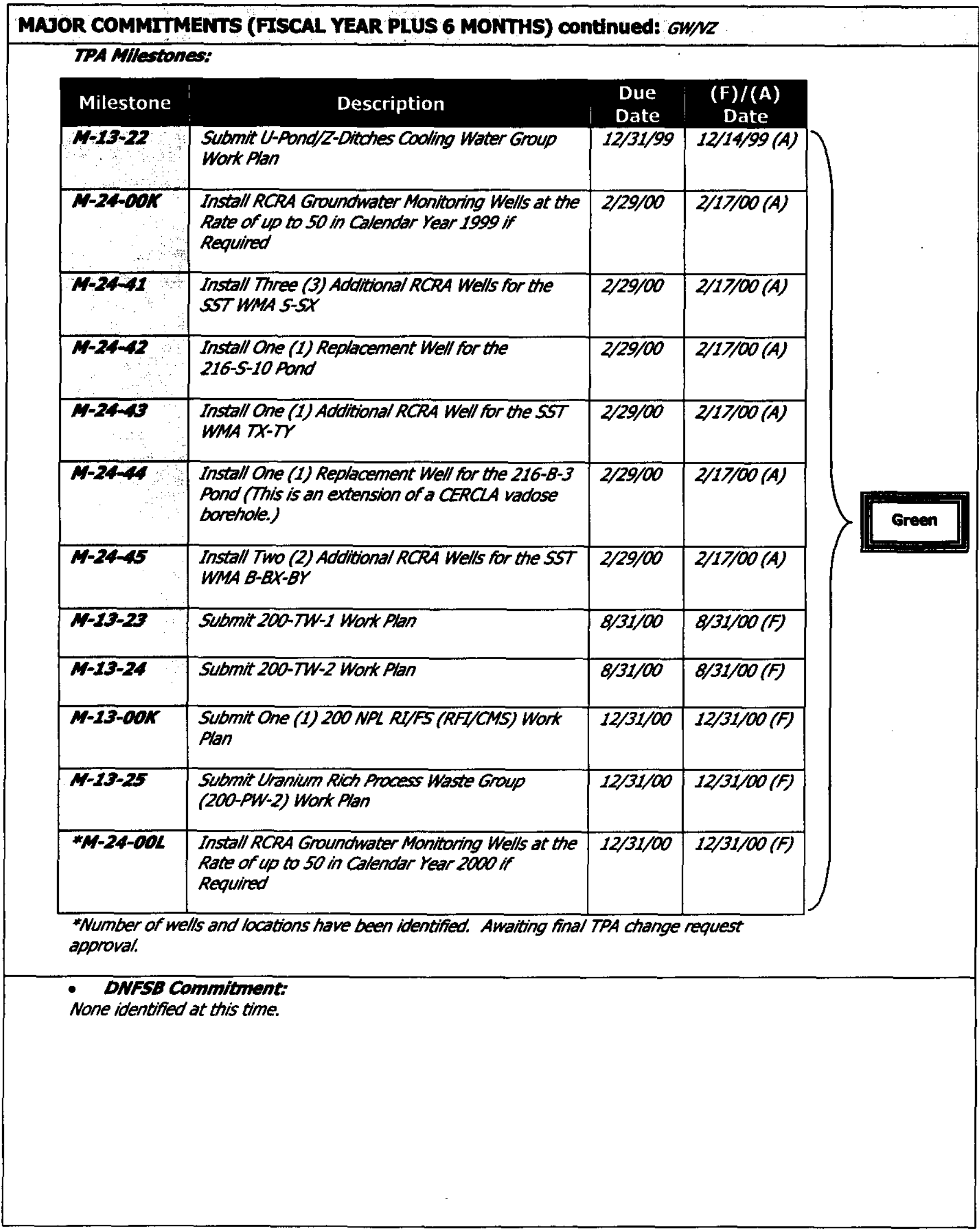




\section{ENVIRONMENTAL MANAGEMENT PERFORMANCE REPORT ENVIRONMENTAL RESTORATION \\ JULY 2000}

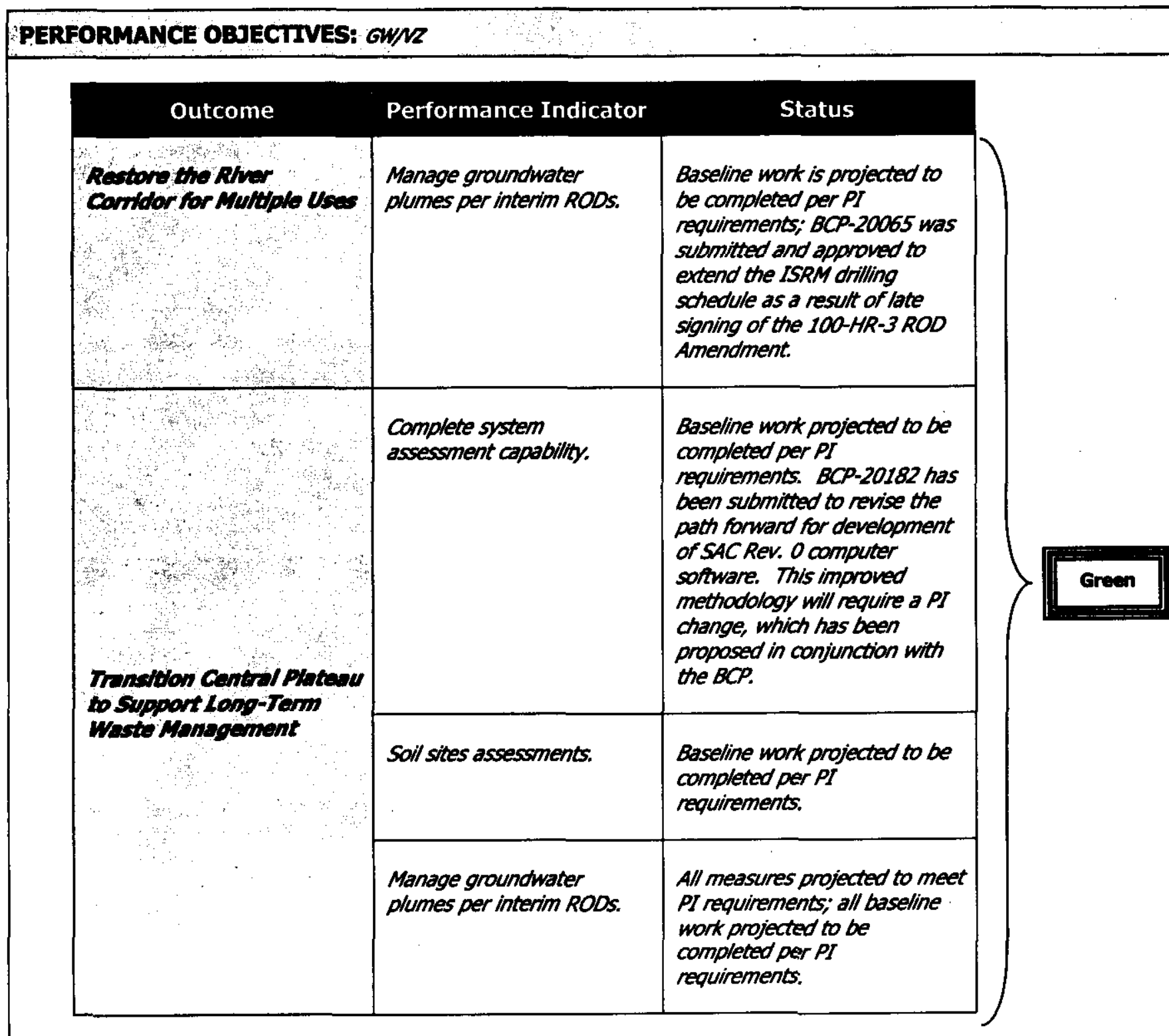

PERFORMANCE MEASURES: GWNZ

None planned in FY 2000. 


\section{ENVIRONMENTAL MANAGEMENT PERFORMANCE REPORT ENVIRONMENTAL RESTORATION \\ JULY 2000}

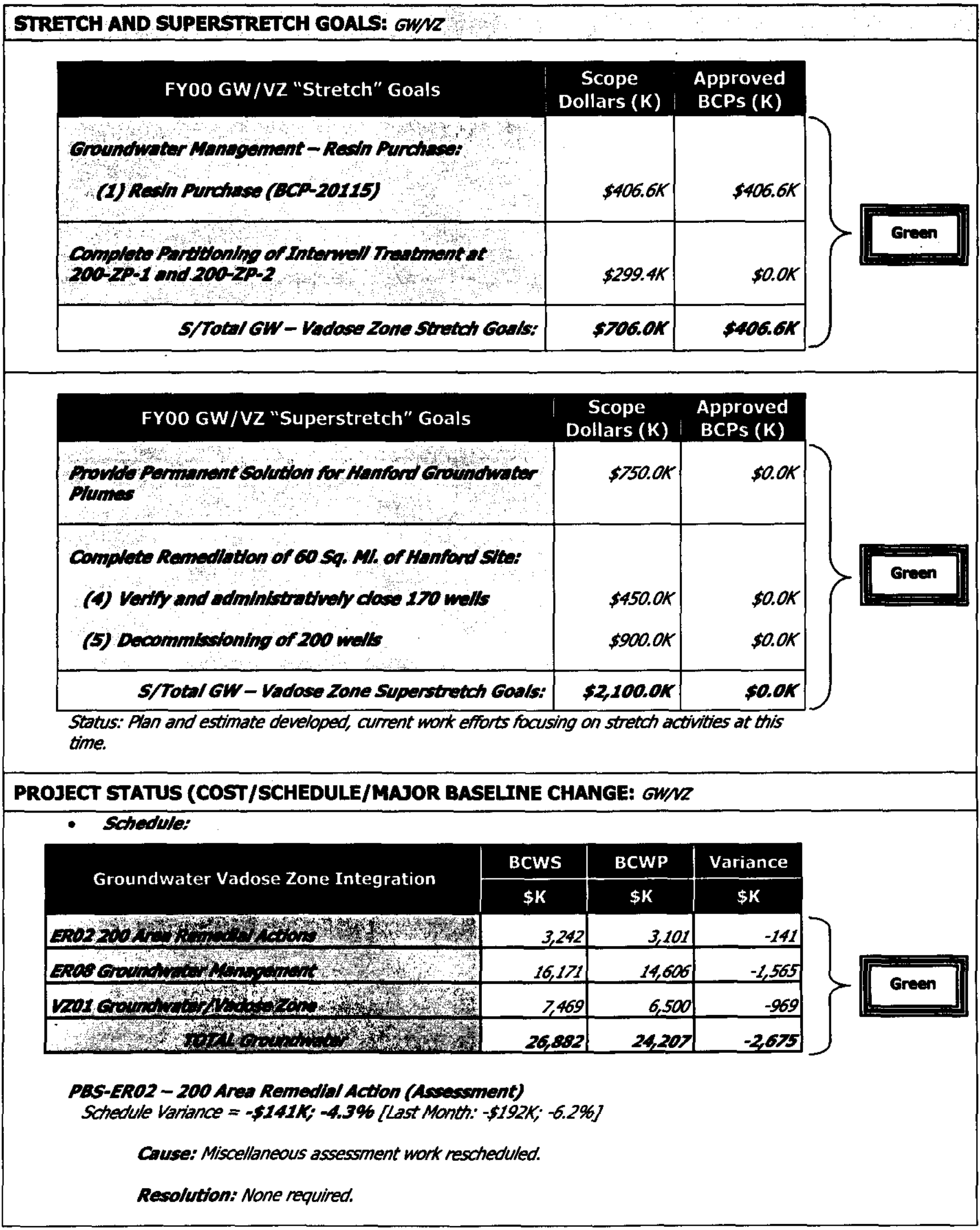




\section{ENVIRONMENTAL MANAGEMENT PERFORMANCE REPORT ENVIRONMENTAL RESTORATION \\ JULY 2000}

\begin{tabular}{|c|c|c|c|c|}
\hline \multicolumn{5}{|c|}{ PROJECT STATUS (COST/SCHEDULE/MAJOR BASELINE CHANGE) continuEd: GWNZ } \\
\hline \multicolumn{5}{|c|}{$\begin{array}{l}\text { PBS-ERas - Groundwater Managememt } \\
\text { Schedule Vaniance }=-\$ 1565 \% ;-9.7 \% \text { [Last Month: }-\$ 1521 \mathrm{~K} ;-10.6 \% \text { ] }\end{array}$} \\
\hline \multicolumn{5}{|c|}{ Cause: ISRM material arthing later than original plan. } \\
\hline \multicolumn{5}{|c|}{ Resolution: None required; material delivery will support ISRM injection work. } \\
\hline \multicolumn{5}{|c|}{$\begin{array}{l}\text { Cause: Groundwater Monitoring sampling collection and analysis (PNNL) fell behind } \\
\text { schedule in October/November, due to resolution of labor contractual issue, and has } \\
\text { not yet recovered. }\end{array}$} \\
\hline \multicolumn{5}{|c|}{$\begin{array}{l}\text { Resolution: Additional NCOs have been added and a recovery schedule } \\
\text { implemented; unexpected sampling at the 618-11 Burial Ground will impact recovery } \\
\text { timing; full recovery is not expected before summer. }\end{array}$} \\
\hline \multicolumn{5}{|c|}{$\begin{array}{l}\text { Cause: Waste shipments to ERDF and resin regeneration at Pump and Treat units } \\
\text { have been delayed due to waste disposition issue; no significant impact. }\end{array}$} \\
\hline \multicolumn{5}{|c|}{ Resolution: Waste regeneration shipments have been scheduled through FH. } \\
\hline \multicolumn{5}{|c|}{$\begin{array}{l}\text { PBS-VZ01 - Groundwater/Vadose Zome } \\
\text { Schedule Variance }=-\$ 969 ;-13.0 \% \text { [Last Month: }-\$ 1188 \% ;-18.2 \% \text { ] }\end{array}$} \\
\hline \multicolumn{5}{|c|}{$\begin{array}{l}\text { Cause: Peer review subpanel meeting was rescheduled; formation of characterization } \\
\text { core team delayed. }\end{array}$} \\
\hline \multicolumn{5}{|c|}{$\begin{array}{l}\text { Resolution: Expect full recovery on peer review scheduling; core team established; } \\
\text { deliverable extended by RL. }\end{array}$} \\
\hline \multicolumn{5}{|c|}{$\begin{array}{l}\text { Cause: Resource availability has delayed Characterization of Systems development } \\
\text { activity. }\end{array}$} \\
\hline \multicolumn{5}{|c|}{$\begin{array}{l}\text { Resolution: Subcontract staff has been added to supplement existing staff; expect } \\
\text { recovery in July. }\end{array}$} \\
\hline \multicolumn{5}{|l|}{ - Cost: } \\
\hline \multirow{2}{*}{ Groundwater Vadose Zone Integration } & BCWP & ACWP & Variance & \\
\hline & $\$ \mathbf{K}$ & $\$ K$ & $\$ \mathbf{K}$ & \\
\hline ER02 200 L 10 & 3,101 & 2,114 & 987 & \\
\hline 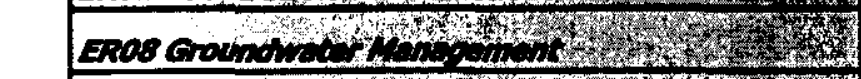 & 14,606 & 14,047 & 559 & Green \\
\hline 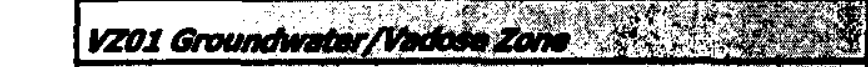 & 6,500 & 6,088 & 412 & \\
\hline 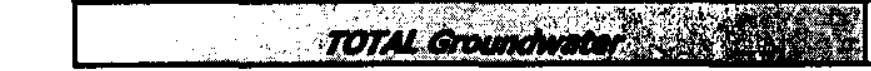 & 24,207 & 22,249 & 1,958 & \\
\hline \multicolumn{5}{|c|}{$\begin{array}{l}\text { PBS-ERO2 - 200 Ares Remedial ACtion (Ascsessment) } \\
\text { Cost Variance }=+\$ 987 K ;+31.8 \% \text { [Last Month: }+\$ 830 K ;+28.7 \% \text { ] }\end{array}$} \\
\hline \multicolumn{5}{|c|}{$\begin{array}{l}\text { Cause: Efficiencies learned in prior work were applied to Gable Mountain and B-Pond } \\
\text { test pit trenching, resulting in savings. Borehole drilling was combined with RCRA } \\
\text { drilling resulting in cost savings. }\end{array}$} \\
\hline \multicolumn{5}{|c|}{ Resolution: Savings will be used to perform other remediation work. } \\
\hline
\end{tabular}




\title{
ENVIRONMENTAL MANAGEMENT PERFORMANCE REPORT ENVIRONMENTAL RESTORATION \\ JULY 2000
}

\author{
PROJECT STATUS (COST/SCHEDULE/MAJOR BASELNE CHANGE) CONUINUEd: GWNZ \\ PAS-GROS - Grounduater Monagement \\ Cost Variance $=+\$ 559 \% ;+3.8 \%$ [Last Month: $+\$ 438 \% ;+3.4 \%$ ] \\ Consea Underrun due to completion of drilling of ISRM ahead of schedule. \\ Resolutiont Savings will be used to perform other remediation work. \\ PRS-VZO1 - Groundwater/Vadose Zone \\ Cost Variance $=+\$ 412 K_{;}+6.3 \%$ [Last Month: $+\$ 287 K_{;}+5.4 \%$ ] \\ Cause; Efficiencies in Science and Technology labor and characterization of systems \\ performed with fewer resources.
}

Resolution: Savings will be used to perform ather remediation work.

RECULATORY ISSUES: GWNZ

Monitoring Wellst Tritium investigation is being conducted near the 618-11 Burial Ground.

Shtus: Results of the Phase I characterization have been reviewed and compiled in a PNWL report. Draft A of the DQO Report for Phase II efforts will be reviewed by the regulators. A work document for field implementation is being prepared.

200-2P-2; Regulatory agencies desire continued aperation of the 200-ZP-2 vapor extraction unit (not included in DWP).

Stalus: Project personnel met with EPA (Doug Sherwood), to discuss the need to restart ZP-2 pending completion of the cost estimate to perform the Partitioning Interwell Tracer Test (PITT) test in lieu of restarting ZP-2 this fiscal vear. Decision has been made to proceed with the PITT test. PITT test estimate will be completed by the end of July, with management review to be completed by mid August.

200 Area Rr/FS: Approximately 800 soil contaminated sites (200 Area) grouped into 23 process-based operable units are to be characterized by 2008 and remediated by 2018. Currently, an out-year funding allowance of $\$ 2 M$ to $\$ 3 M$ has been added to the GWNZ Project for 200 Area characterization work, but this is not sufficient to meet TPA milestones. Longterm, RL must decide a budgetary position toward assessment and cleanup of the 200 Aras liquid waste sites. The regulator position is to submit TPA change packages for each operable unit work plan for enforceability in completing the RI through ROD based on existing TPA milestones.

Status: DOE has prepared a draft TPA change package for the 200-CW-1 operable unit containing RIJFS milestones for FY 2000 only. DOE is also working on how to address the need for TPA change package proposals for the other wonk plans that require a proposed TPA change package in order to gain necessary regulatory approval of the work plan. In addition, DOE is currentty working on ways to revise the existing long-term strategy for prionitizing the 200 Area assessment and remediation activities in conjunction with other site cleanup decisions. RL management plans to meet with regulators to discuss the appraach to this work.

200 PW-2 Work Plon: RL direction is needed on proceeding with the 200-PW-2 Work Plan. Initiating work on the 200-PW-2 OU is not consistent with funding levels nor RL's path forward strategy for the 200 Area.

Status: TPA Milestone $M-13-25$ requires that the Draft A 200-PW-2 work plan be submitted to the regulators by December 31. RL has directed BHI to resume development of the work plan. 


\section{ENVIRONMENTAL MANAGEMENT PERFORMANCE REPORT ENVIRONMENTAL RESTORATION \\ JULY 2000}

RECULATORY ISSUES continued: GWNZ

M-24-00L - CrOO RCRA Compliance Well Installation: The number and location of wells have been determined. However, the interim milestones are in dispute.

Status: The change request establishing TPA interim milestones is still in dispute resolution (dispute resolution was extended to June 30). Ecology's TPA change request has been received and is in final approval process. $A B C P$ has been submitted based on a FY 2000 and a CY 2000 target date.

Waste Handling: On May 31, a Notice of Correction (NOC) letter was received by RL from Ecology. This NOC detailed the violations and corrections regarding the shipments of mixed solid waste that contacted groundwater that contains listed waste (FY 2001 and FY 2003), and the drums of M-24 drilling waste at the Biosite. On June 15, a letter was received from EPA identifying violations of CERCLA requirements with respect to waste management practices at 100-F, 100-K, 100-BC, 200-ZP-1, 300-FF-2 operable units. This letter also served as notice that the moratorium on disposal of investigation derived waste (IDW) into ERDF is no longer in place. EPA requires that all IDW shipments to ERDF be approved by EPA ERDF project manager until further notice.

Status: Corrective actions identified in the letters are being addressed. Extensions have been granted by the regulators to allow time for resolution and response to identfied items. Additional meetings have been held to move toward dosure.

EXTERNAL ISSUES (i.e. HAB, Congress, etc.): GWNZ

None identified at this time.

DOE-RL \& HQ ISSUES/REQUESTS (not covered elsewhere): GWNZ None identified at this time.

INTEGRATION ACTINITES: GWNZ

None identified at this time. 


\section{Surveillance/Maintenance and Transition Project (SM\&T)}




\title{
ENVIRONMENTAL MANAGEMENT PERFORMANCE REPORT ENVIRONMENTAL RESTORATION \\ JULY 2000
}

\section{SECTION C - TRANSITIONING THE CENTRAL PLATEAU}

\author{
Financial / Performance Measures data as of month-end May. \\ All other data as of June 22, 2000 (unless otherwise noted). \\ Surveillance/Maintenance \& Transition Project (SM\&T):
}

\section{ACCOMPLISHMENTS: SMRT}

Survelliance and Malntenance. S\&M activities that were performed in May to ensure inactive facility integrity and safety included the following:

- Completion of the legacy waste removal at both KE and KW Reactors. The legacy waste removal scope was verified to be satisfactorily completed by RL field inspection of the work sites and review of work packages and shipping documents.

- Commencement of legacy waste removal at H Reactor.

- Completion of the readiness assessment for the REDOX Facility plutonium laadout hood work. Initiation of field work activities including decontamination of the backside of the hood and sampler box isolation.

- Completion of the acceptance test for the $100 \mathrm{~N}$ Area water plant.

- Completion of the work packages for KE/KW acid tank stabilization work activities.

- Completion of sealing 39 out of 84 passive vents source elimination at the RARA sites.

Canyon Dispostition Initiative (CDI): Several activities continued in support of the CDI, induding movement of equipment off the cell cover blocks, lifting the cell blocks, videotaping the cell contents, and utilizing a gamma camera to take radiological profiles of the cells. 19 of the planned 26 cells have been accessed at the U Plant (221-U Building) canyon facility during Fy 2000. Railroad tunnel door repair activities were completed.

Training was completed on the Brokk ${ }^{T m}$ coring machine. This equipment will take concrete core samples inside the CDI access cells, and will be remotely operated by the canyon crane.

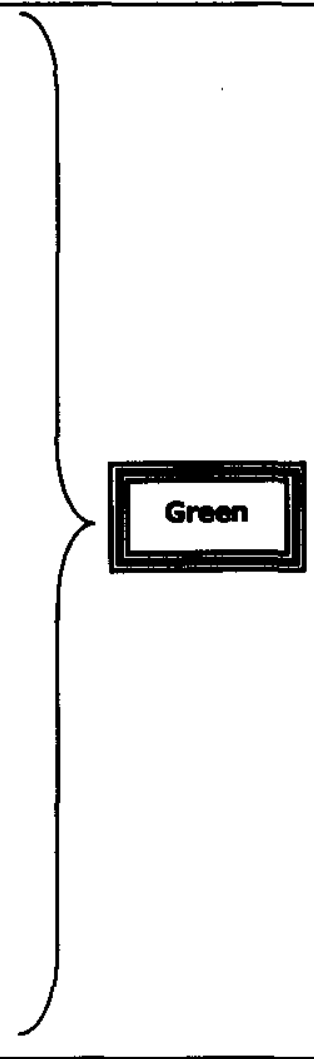

\section{SAFETY/ISMS/CONDUCT OF OPERATIONS: SMRT}

See Executive Summary.

\section{BREAKTHROUGHS/OPPORTUNITIES FOR IMPROVEMENT: SMQT}

None identified at this time.

LONG-TERM (6 MONTHS PLUS) IMPORTANT ITEMS: SM\&T

None identified at this time.

\section{MAJOR COMMITMENTS (FISCAL YEAR PLUS 6 MONTHS): SMBT}

- DOE Secretarialt

None identified at this time.

- DOE EM Periomance Agreement:

None identified at this time. 


\section{ENVIRONMENTAL MANAGEMENT PERFORMANCE REPORT ENVIRONMENTAL RESTORATION \\ JULY 2000}

\begin{tabular}{|c|c|c|c|}
\hline \multicolumn{4}{|c|}{ MAJOR COMMITMENTS (FISCAL YEAR PLUS 6 MONTHS) continUEd: SMET } \\
\hline \multicolumn{4}{|l|}{$\begin{array}{l}\text { TPA Milestones: } \\
\text { None identified at this time. }\end{array}$} \\
\hline \multicolumn{4}{|l|}{$\begin{array}{l}\text { DNFSB Commitment: } \\
\text { None identified at this time. }\end{array}$} \\
\hline \multicolumn{4}{|c|}{ PERFORMANCE OBJECTIVES: SMQT } \\
\hline Outcome & Performance Indicator & Status & $\cdot$ \\
\hline $\begin{array}{l}\text { Restoro uto R/ver } \\
\text { Corridor for Muttplo Uses }\end{array}$ & $\begin{array}{l}\text { Deactivation and preparation for } \\
\text { decommission. }\end{array}$ & $\begin{array}{l}\text { Baseline work is projected } \\
\text { to be completed per PI } \\
\text { requirements. }\end{array}$ & \\
\hline 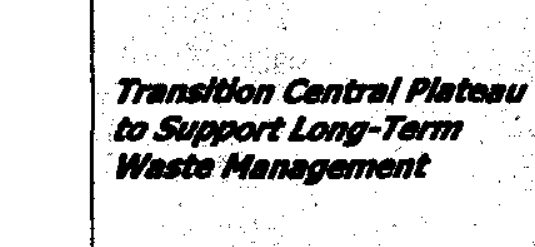 & $\begin{array}{l}\text { Perform S\&M/risk reduction on } \\
\text { inactive facilities to } \\
\text { eliminate/stabilize } \\
\text { environmental, human hea/th } \\
\text { hazards until D\&D; Perform CDI } \\
\text { activities. }\end{array}$ & $\begin{array}{l}\text { CDI baseline work } \\
\text { projected to be completed } \\
\text { per PI requirements. } \\
\text { DOE-Waste Management } \\
\text { funding shortfalls will } \\
\text { require scope adjustment. }\end{array}$ & Groen \\
\hline
\end{tabular}

PERFORMANCE MEASURES: SMQT

None planned in FY 2000.

STRETCH AND SUPERSTRETCH GOALS: SMBT

\begin{tabular}{|c|c|c|}
\hline FYOO SM\&T "Stretch" Goals & $\begin{array}{l}\text { Scope Dollars } \\
\text { (K) }\end{array}$ & $\begin{array}{l}\text { Approved } \\
\text { BCPs (K) }\end{array}$ \\
\hline $\begin{array}{l}\text { Daactivate 183-N Water Trastment Plant } \\
\text { (Phase I) (BCP-20111) } \\
\text { Danctivete 183-N Water Treatment Plant } \\
\text { (Phase II) (BCP-20175) }\end{array}$ & $\begin{array}{l}\$ 131.0 K \\
\$ 159.0 K\end{array}$ & $\begin{array}{l}\$ 131.0 K \\
\$ 159.0 K\end{array}$ \\
\hline $\begin{array}{l}\text { Asbeotas Abutement a Repoliss (100, 200, a } \\
300 \text { Arass). }\end{array}$ & $\$ 470.0 K$ & $\$ 64.2 K$ \\
\hline $\begin{array}{l}\text { Complete the CDI Tecthical Work to Support } \\
\text { the Phase II Fansibility Study }\end{array}$ & $\$ 490.0 K$ & $\$ 0.0 K$ \\
\hline S/Total SMET -Facillty Transition Strotch Gaalst & $\$ 1,250.0 K$ & $\$ 354.2 K$ \\
\hline
\end{tabular}




\section{ENVIRONMENTAL MANAGEMENT PERFORMANCE REPORT ENVIRONMENTAL RESTORATION \\ JULY 2000}

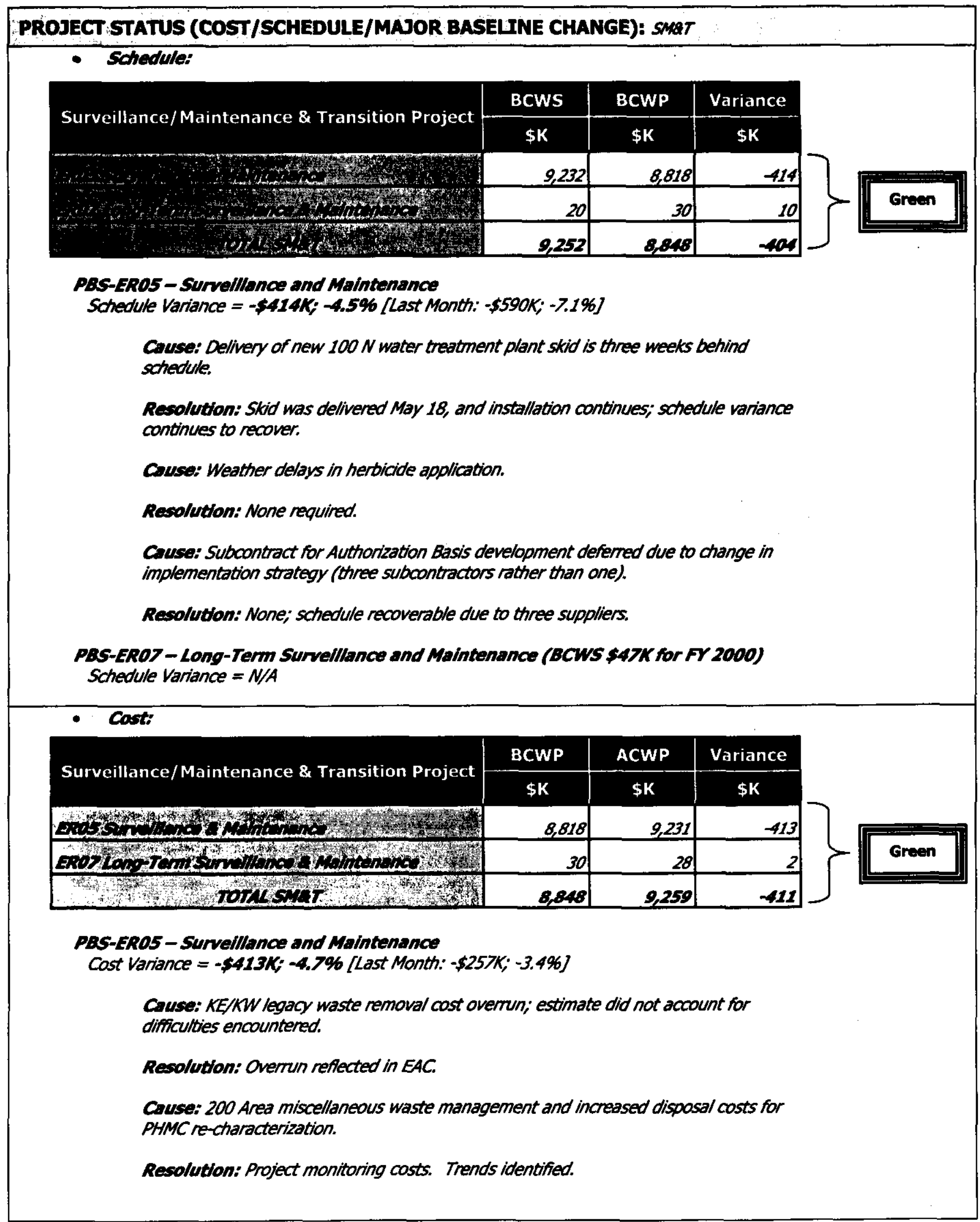




\title{
ENVIRONMENTAL MANAGEMENT PERFORMANCE REPORT ENVIRONMENTAL RESTORATION \\ JULY 2000
}

\author{
PROJECT STATUS (COST/SCHEDULE/MAJOR BASELINE CHANGE) continued: SMAT \\ Cause: Undemuns on B Plant S\&M and RARA stabilization from work practice \\ efficiencies. \\ Resolution: Underrun will be utilized for other ER work. \\ PBS-ERO7 - Long-Term Survellance and Maintenance (BCWS \$47K for FY 2000) \\ Cost Vartance $=N / A$
}

RECULATORY ISSUESA SMaT

None identified at this time.

EXTERWAL ISSUES (1.e. HAB, Congress, etc.), SMBT

None identified at this time.

\section{DOE-RL \& HQ ISSUES/REQUESTS (not covered elsewhere): SWRT}

$B$ Plant/PUREX Roor Funding: Ensure funding is provided by Facility Transition Project per MOUs to support roof repair commitments for $B$ Plant and PUREX. Facilities were transitioned to ER with the commitment to fund these repairs from the releasing project.

Status: Funding for roof repairs have not been induded within the current abovethe-line Integrated Priority List targets. The roof leaks based on last quarterty surveillance.

B plant Stact Ventlation: Problems with stack ventilation, retired fitters, and ather issues documented in letter, M.C. Hughes to R. Gerton, September 28, 1999, "Remaining Issues for the Transition of the B Plant Facility from EM-60 to EM-40".

Status: Facility transferred to ERC September 30, 1999. MOA with open items assigned cost/schedule responsibility received September 30, 1999. Original MOA schedule not met. Fluor Hanford (FH) repaired the ductwork on May 2 and performed a keak test on the repaired areas. BHI issued a letter on May 3 to FH requesting additional information and testing be performed on the exhaust fan assembly in order to meet our minimum requirements to assure the repaired assembly will continue to operate correctty. FH has responded to the letter, and RL concurrence on acceptability is planned for the end of June.

Hexone Tanks: A Notice of Correction was received from Ecology on May 26. Ecology stated that the hexone tanks were inadequately inspected, and the waste designator on the tanks was not stated property per Washington Administrative Code (WAC) 173-303, Dangerous Waste Regulations.

Status: A BCP has been submitted to perform DQDs on the herone tanks. Tank inspection frequency was changed to daily on the nitrogen purge, and to monthly on the purge system integrity. A response letter is being drafted for submittal to Ecology by June 23.

INTEGRATION ACTIVITIES: SMRT

None identified at this time. 


\section{Pacific Northwest National Laboratory Environmental Management Performance Report}

July 2000

PREPARED FOR THE U.S. DEPARTMENT OF ENERGY, RICHLAND OPERATIONS OFFICE OFFICE OF ENVIRONMENTAL MANAGEMENT

Pacific Northwest National Laboratory

Operated for the U.S. Department of Energy

by Battelle Memorial Institute 


\section{Table of Contents}

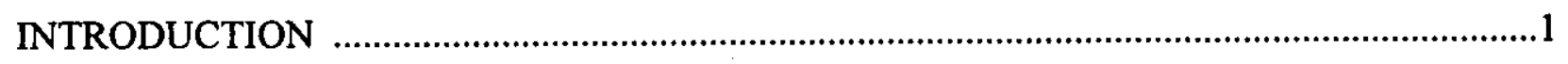

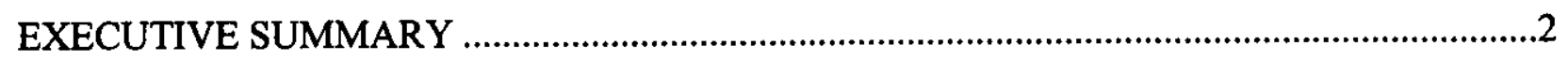

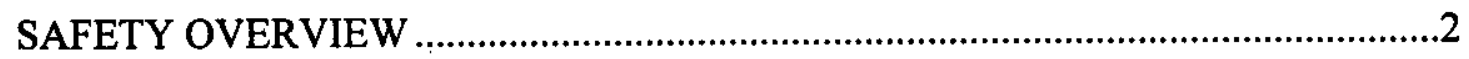

VOLUNTARY PROTECTION PROGRAM …………..............................

COST/SCHEDULE PERFORMANCE STOPLIGHT .................................................

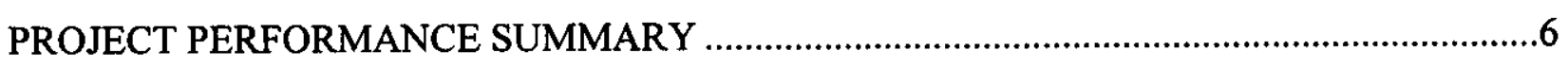

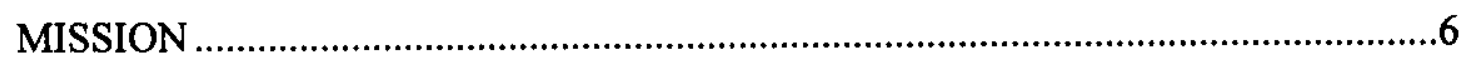

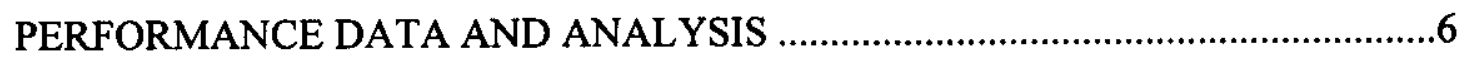


This document provides the Department of Energy Richland Operations Office (DOE-RL) 1 with a report of the Pacific Northwest National Laboratory (PNNL) performance by Battelle Memorial Institute and its subcontractors.

In Section A, the Executive Summary, text and graphics report the safety metrics status for all PNNL activities. Senior management's overall performance assessment of all Environmental Management activities conducted at PNNL is presented in a stoplight chart.

Section B, Project Performance Summary, provides a brief summary of the month's performance for the PNNL lead activity, PNNL Waste Management (PBS RL-ST01). More detailed information can be found within PNNL-7911-104a, PNNL's Project Status Report for May 2000. Summary analyses pertaining to PNNL's support to other Project Baseline Summaries (PBSs) are addressed in the contractor's report having lead responsibility for that scope.

Unless otherwise noted, information in this report is current as of May 28, 2000. 
This section provides an executive-level summary of performance information and is intended to bring to Management's attention that information considered to be most noteworthy. The section begins with overviews of safety, followed by a stoplight chart on overall performance.

\section{Safety Overview}

The focus of this section is on documenting trends in work-related injuries and illnesses rates.

Improvements in these rates result from PNNL's continued implementation of the Integrated Environment, Safety, and Health (ES\&H) Management System (ISMS), and the current development and implementation of the Voluntary Protection Program (VPP). Injury and Illness statistical data are presented graphically in this section followed by a summary of the completed and planned actions for the PNNL VPP.

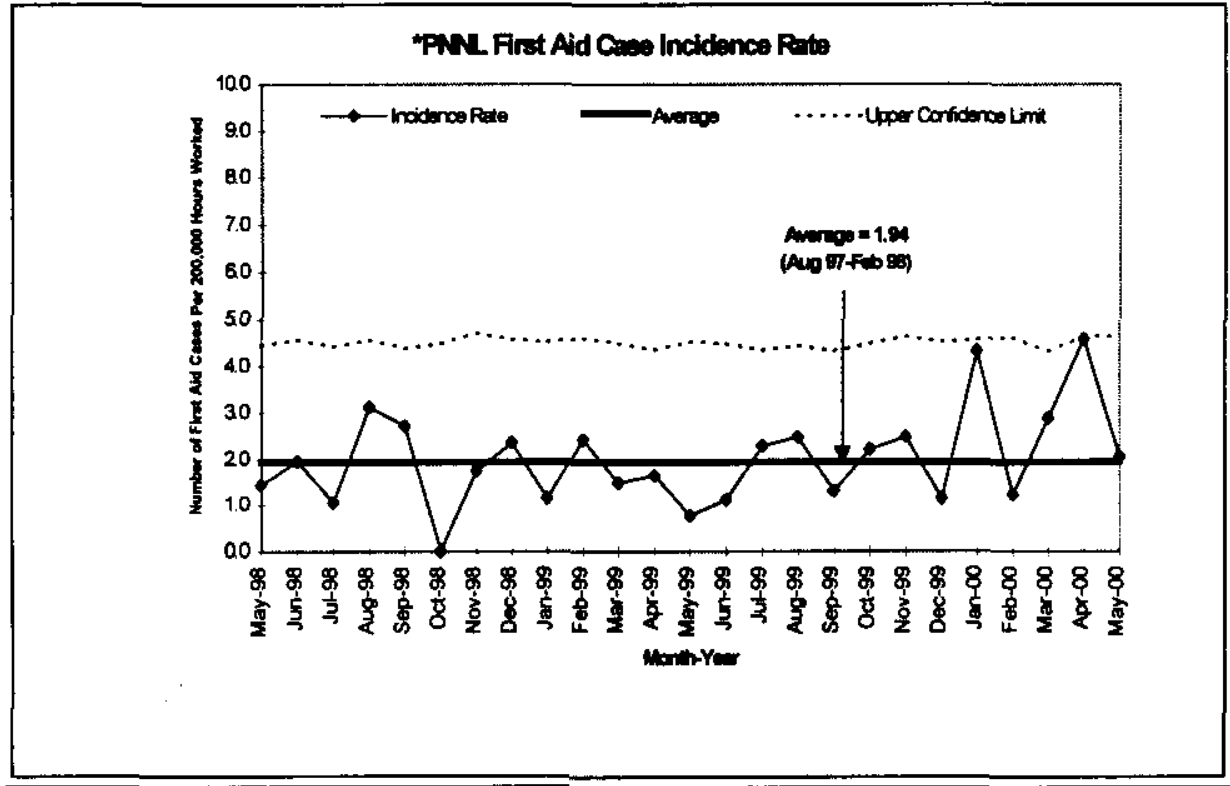

RateOverview:

FY00 To Date $=2.61$

FY99 $=1.56$

The data over the past two fiscal years has been relatively stable. The current fiscal year continues to demonstrate a general increase and the data are being monitored for future changes and stabilization.

\footnotetext{
*Includes all Pacific Northwest National Laboratory Operations.
} 


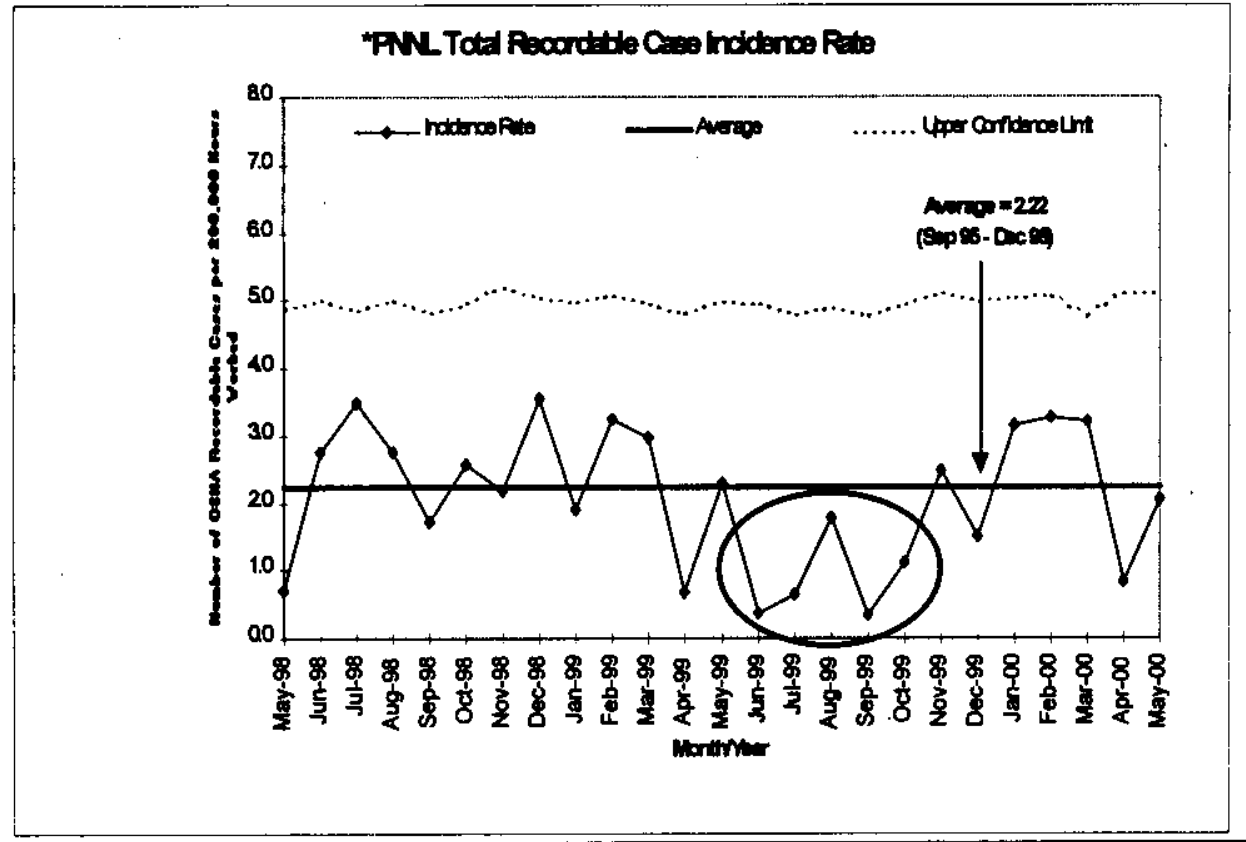

Rate Overview:

FY00 To Date $=2.22$

FY99 $=1.80$

FY99 DOE Research

Contractor Avg $=2.6$

This indicator has been generally stable over the long term. There was however, a decrease in the rates during the period of April 99 - October 99 followed by an increase back to the previous levels for the period of Nov99-Mar00. The data for the last two months is again below the 2.22 average and monitoring continues for future stabilization.
PNML Loet Workday Case Incidence Rate

8

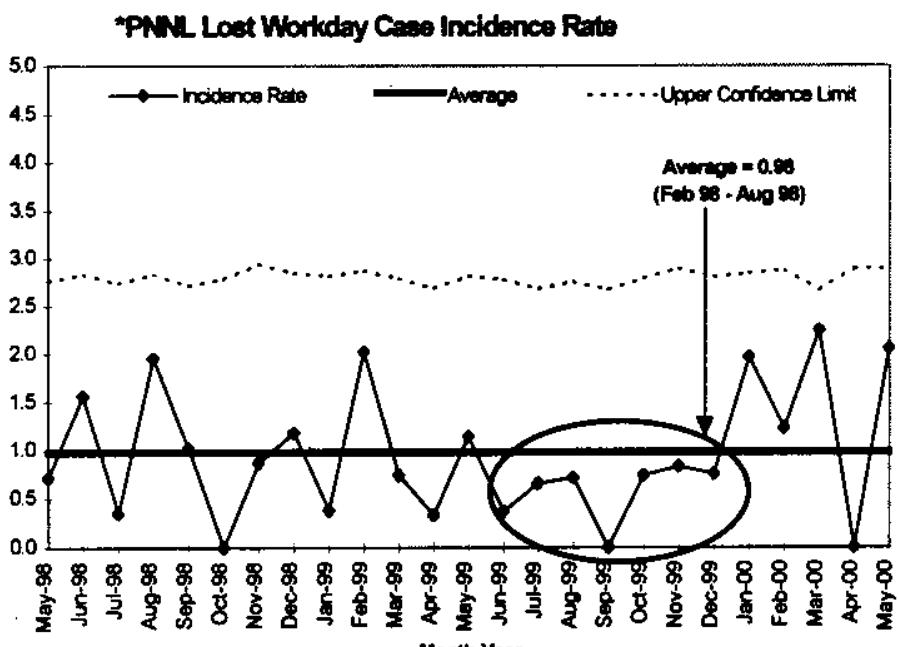

Honth-Yer
Rate Overview:

FY00 To Date $=1.25$

FY99 $=0.67$

FY99 DOE Research

Contractor

Avg $=1.1$

This indicator has been generally stable over the long term. There was a temporary short-term decrease during the period of June 99 - December 99 followed by an increase back up to levels near the pre June 99 rates. Data are currently being monitored for future stabilization. 


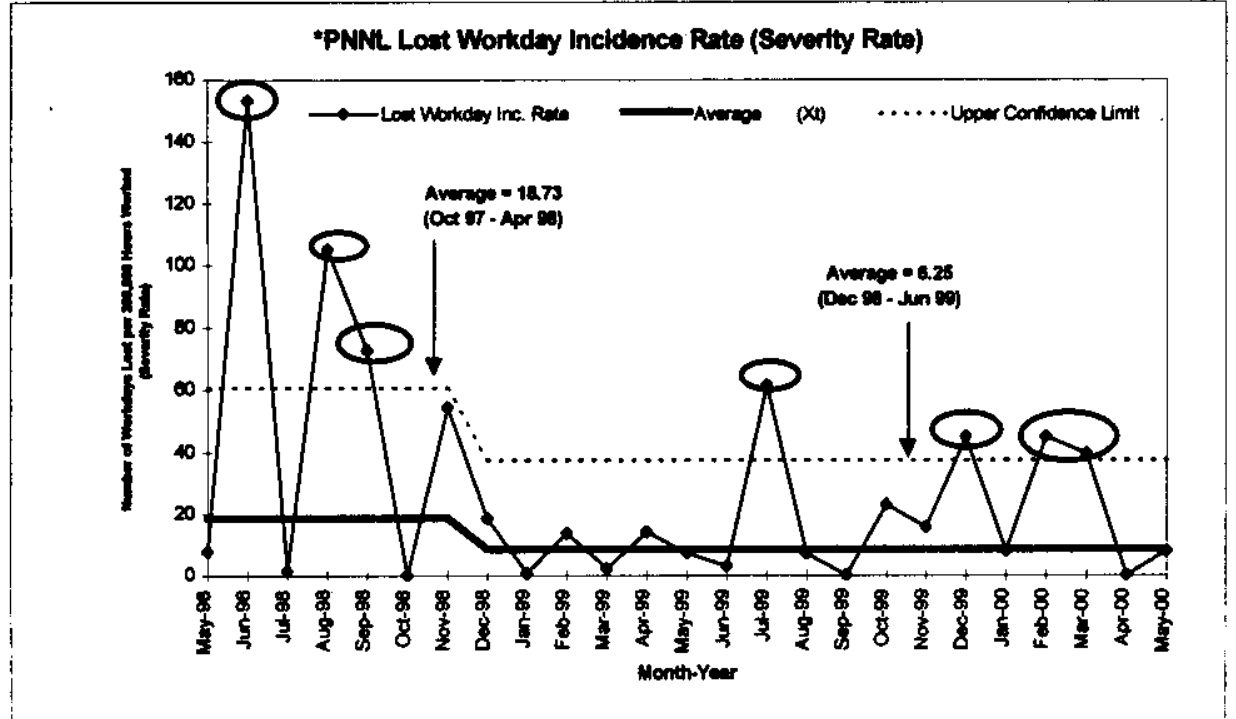

Rate Overview:

FY00 To Date $=23.20$

FY99 $=21.45$

FY99 DOE Research

Contractor Average $=\mathbf{2 2 . 8}$

The data for the last two months have returned to levels below the Dec 98 - Jun 99 average. The Dec 99 rate climbed above the upper control limit due to the accumulation of additional lost workdays on an active case. Out of the remaining months with data points above the upper control limit, Jun 98 and Mar 00 are the only months currently accumulating lost workdays.

\section{Overall FY00 Safety Performance}

\begin{tabular}{|l|c|c|c|}
\hline & $\begin{array}{r}{ }^{*} \text { Fiscal } \\
\text { YTD } \\
\text { Count }\end{array}$ & $\begin{array}{r}\text { Current Month } \\
\text { Count } \\
\text { (May) }\end{array}$ & $\begin{array}{c}\text { Current Month Injury Types } \\
\text { (May) }\end{array}$ \\
\hline First Aid Cases & 54 & 5 & $\begin{array}{l}\text { (1) Contusion, (3) Strain, } \\
\text { (1) Insect Bite/Sting }\end{array}$ \\
\hline $\begin{array}{l}\text { Recordable Cases } \\
\text { (All) }\end{array}$ & 46 & 5 & $\begin{array}{l}\text { (1) Fracture, (1) Burn, } \\
\text { (3) Strain }\end{array}$ \\
\hline $\begin{array}{l}\text { **Lost Workday } \\
\text { Cases }\end{array}$ & 26 & 5 & $\begin{array}{l}\text { (1) Fracture, (1) Burn, } \\
\text { (3) Strain }\end{array}$ \\
\hline $\begin{array}{l}\text { As of 05/31/00 PNNL had worked approximately 139,680 hours since the last lost workday } \\
\text { case. }\end{array}$
\end{tabular}

* Fiscal Year to Date (YTD) counts may change from previous totals due to periodic case updates/reclassifications.

**Includes all Lost and Restricted Workday Cases. 


\section{Voluntary Protection Program}

PNNL continues to actively pursue "star" status and is on target to submit a VPP "star" status application in September 2000.

Recent PNNL VPP activities:

- Participated Seattle VPP Region X Conference, May 2000.

- Distributed VPP informational pamphlets and VPP survey to all staff.

Planned PNNL VPP Activities:

- 6 PNNL staff are scheduled to attend DOE/OSHA Onsite VPP Evaluation Class in Mid-June 2000.

- Participation in VPP National Convention to be held in Seattle, August 2000.

- Steering Committee members are scheduled to distribute VPP awards at the end of June 2000.

\section{Cost/Schedule Performance Stoplight}

The following rating reflects overall cost/schedule performance for activities conducted by PNNL. (Narrative not required when rating is green.)

$\begin{array}{ll}\text { Green: } & \text { Satisfactory } \\ \text { Yellow: } & \text { Significant improvement required } \\ \text { Red: } & \text { Unsatisfactory }\end{array}$


$\mathrm{T}$ his section provides cost and schedule performance, any significant issues, and upcoming baseline change requests for the period covered. In fiscal year (FY) 2000, Battelle Memorial Institute has lead responsibility over PBS RL-ST01, PNNL Waste Management WBS 1.7.1.

\section{Mission}

WBS 1.7.1 provides PNNL with waste management services and compliant operations in support of science and technology development for the multiprogram needs of the U.S. Department of Energy (DOE) Complex. These services include:

- essential surveillance and maintenance of DOE laboratory facilities assigned to PNNL for safe containment of radioactive and hazardous materials

- infrastructure required to manage wastes and effluents currently generated at the PNNL

- operational compliance services to meet regulatory requirements and operating permits including environment, safety, and health regulations

- management of legacy wastes and contamination remaining from past PNNL research operations.

\section{Performance Data and Analysis}

As of May 28, 2000 the cumulative costs are $\$ 8.6$ million with a positive cost variance of $\$ 0.4 \mathrm{M}$ and a cumulative schedule variance of negative $\$ 0.9 \mathrm{M}$. Variances are within established thresholds, however, a brief explanation follows the tables and chart.

\begin{tabular}{|c|c|c|c|}
\hline \multicolumn{4}{|c|}{ Cost Performance (\$M): } \\
\hline & BCWP & ACWP & Variance \\
\hline PNNL Waste Management & $\$ 9.0$ & $\$ 8.6$ & $\$ 0.4$ \\
\hline \multicolumn{4}{|c|}{ Schedule Performance (\$M): } \\
\hline & BCWP & BCWS & Variance \\
\hline PNNL Waste Management & $\$ 9.0$ & $\$ 9.9$ & $(\$ 0.9)$ \\
\hline
\end{tabular}

\section{FY 2000 Cost/Schedule Performance - All Fund Types Cumulative to Date Status - (\$000)}

\begin{tabular}{|c|c|c|c|c|c|c|c|c|}
\hline WBS & PBS & BCWS & BCWP & ACWP & $\mathrm{CV}$ & $\%$ & SV & $\%$ \\
\hline 1.7 .1 & RL-ST01 & $\$ 9,877$ & $\$ 8.952$ & $\$ 8,593$ & $\$ 359$ & 4 & $\$(925)$ & $\underline{-9}$ \\
\hline & Total & $\$ 9,877$ & $\$ 8,952$ & $\$ 8,593$ & $\$ 359$ & 4 & $\$(925)$ & \\
\hline
\end{tabular}


Cost / Schedule Performance Indices

FY 2000 Cum to Date Status ( $\$ 0002)$

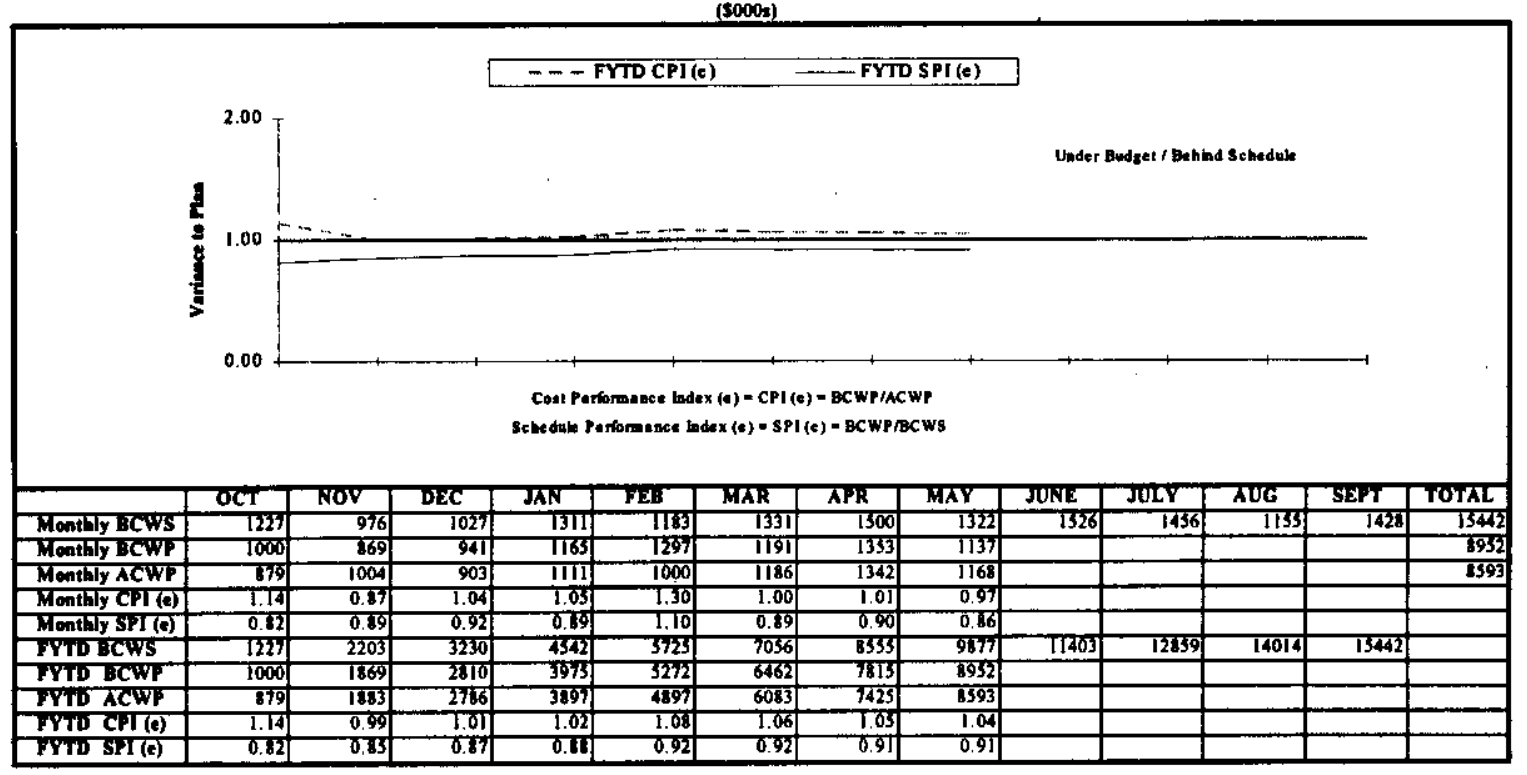

The positive cost variance of $\$ 0.4 \mathrm{M}$ results from reduced overhead rates and delayed billings. A change request.was approved on May 25 to revise the basis of estimate and align budget and funds. That change request will be fully implemented by the end of June. It is also expected that the baseline activities will be completed within the funding allocation. The primary reasons for the cumulative schedule variance of negative $\$ 0.9 \mathrm{M}$ are described below:

- Difficulties in completing the final details in the high dose waste container designs as well as a late start in fabrication of the drum handling system. Delays may postpone shipments into next FY.

- Planned cask shipments to the 200 Area for final disposition affected by RLWS delay. With implementation of the change request the waste disposal scope affected by the RLWS delays will be deleted.

Modifications to 305-B and RPL (Radiochemical Processing Laboratory) Contingency Plans and RLWT (Radioactive Liquid Waste Tank) modifications for RPL HWTUs (Hazardous Waste Treatment Unit), were submitted in May, which will then be submitted to Ecology on July 10. The integrity assessment of the RLWT piping is scheduled for June. The earliest the 204-AR Facility (Receiver facility) will receive waste via the LR-56 Truck is fiscal year ' 01. 


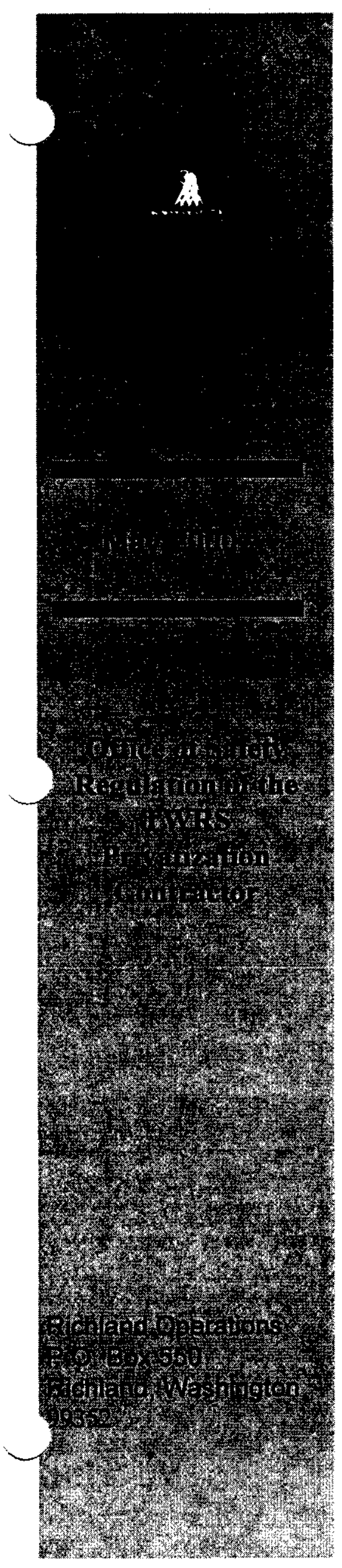

\section{Regulatory Unit \\ Monthly Performance Report}

\section{July 2000 \\ Environmental Management Performance Report Submittal}




\section{Table of Contents}

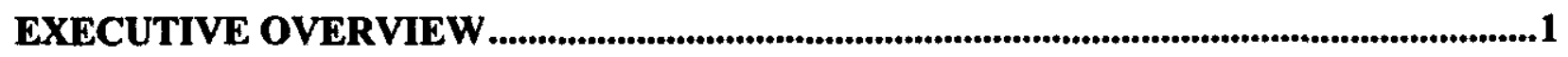

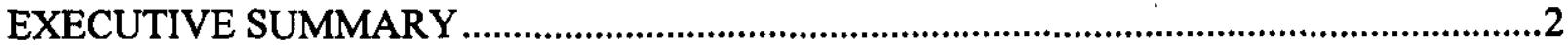

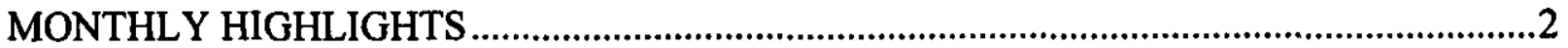

Inspection of the BNFL Inc. Self-Assessment and Corrective Action Programs .................... 2

Inspection of the Independence of the BNFL Inc. Quality Assurance Organization................ 3

Review of the BNFL Part B-1 Facility and Process Design Deliverables............................. 3

Topical Meeting on the Implementation of Integrated Safety Management (ISM) Cycle 2..... 4

Acceptability Review of the BNFL RPP for Design and Construction................................. 4

Review of the BNFL Non-radiological Worker Safety and Health Plan .............................. 4

ISMP Assessment Report ........................................................................................5

Self-assessment of the RU's Readiness-to-Proceed into Part B-2 of the RPP-WTP Contract..5

EIR Team Assessment of DOE Readiness-to-Proceed into Part B-2 .................................. 5

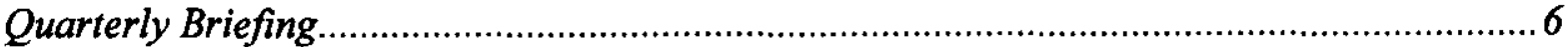

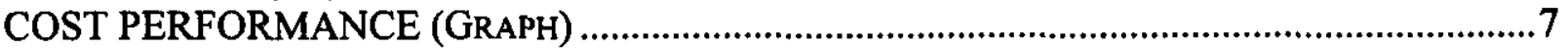

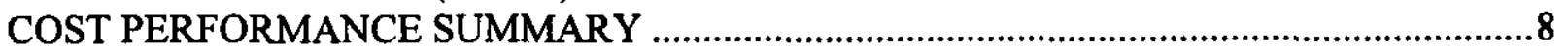

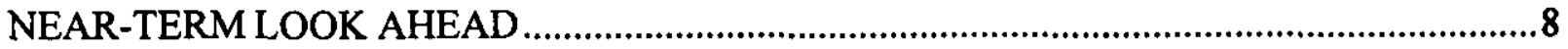

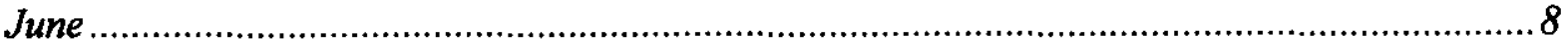

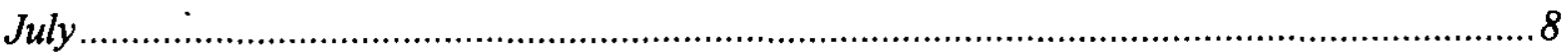

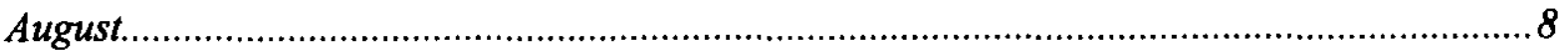

PROGRAM PERFORMANCE OVERVIEW

PERFORMANCE SUMMARY (CHART) - PROGRAM DIRECTION AND PROGRAM SUPPORT.... 10

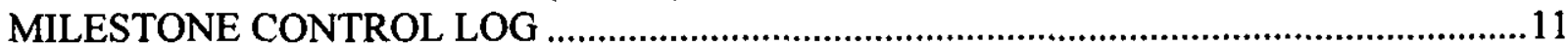

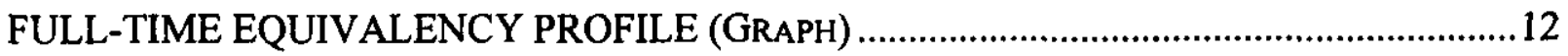

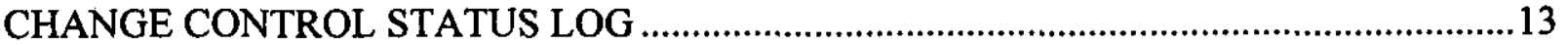




\section{EXECUTIVE OVERVIEW}




\section{EXECUTIVE SUMMARY}

In May the Regulatory Unit ( $R U$ ) focused on its readiness to receive the early sections of the Contractor's Construction Authorization Request (CAR) and on completing preparations for transition to Part B-2 of the Contract, including construction. At the time the decision was made to terminate the BNFL Contract, the RU was fully prepared for transition as confirmed by an External Independent Review team.

The decision to terminate the BNFL Contract raised numerous issues concerning the details of the regulatory process to be applied to the follow-on Contractor(s). In the interest of conserving financial resources and reducing the magnitude of the delays that could follow this decision, EM-1 has directed that the regulatory framework and associated standards-setting process be applied to all contractors engaged in the proposed waste treatment plant activities. Further, the RU will continue to function as an entity independent of the ORP.

Major RU activities during May included:

- issuing an inspection report that assessed the BNFL Self-Assessment and Corrective Action Programs (IR-00-004);

- issuing an inspection report that assessed the independence of the Quality Assurance (QA) Organization (IR-00-005);

- reviewing the BNFL Part B-1 Facility and Process Design Deliverables;

- conducting a topical meeting on Implementation of Integrated Safety Management (ISM) Cycle 2;

- completing the acceptability review of the BNFL Radiation Protection Plan (RPP) for Design and Construction;

- continuing the review of the BNFL Non-radiological Worker Safety and Health Plan;

- issuing a report on the effectiveness of BNFL's implementation of its Integrated Safety Management Plan (ISMP);

- completing a self-assessment of the RU's Readiness-to-Proceed into Part B-2 of the RPP-WTP Contract; and

- supporting an assessment by an External Independent Review (EIR) Team of DOE Readiness-toProceed into Part B-2 of the RPP-WTP Contract.

These significant items, and other notable accomplishments, are detailed below.

\section{MONTHLY HIGHLIGHTS}

\section{Inspection of the BNFL Inc. Self-Assessment and Corrective Action Programs}

The RU issued inspection report IR-00-004 that assessed the BNFL Inc. (BNFL) self-assessment and corrective action programs. Three Findings with multiple examples were identified:

- problem identification and corrective action (quality improvement) procedures were not adequate to describe and control the processes necessary to ensure an effective quality improvement program;

- implementation of corrective actions for identified deficiencies was not timely (twelve examples of 


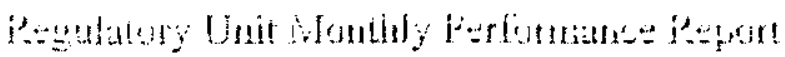

failure to address deficiencies in a timely manner were identified); and

- quality improvement procedures were not being followed (three examples were identified regarding failure to write a Corrective Action Report when a Deficiency Report (DR) was designated as significant).

The Findings described above were of significant concern because the BNFL quality improvement program (problem identification and corrective action) was not being effectively implemented. Inspection results indicated that, in the past, management was not providing appropriate support to the quality improvement program to ensure that problems were being addressed in a timely manner. Also, staff was not applying appropriate priority to quality improvement related activities and was found, in general, to have little knowledge of the program. BNFL was requested to provide a written response to the Findings within 30 days, in accordance with the instructions provided in the Notice of Finding.

\section{Inspection of the Independence of the BNFL Inc. Quality Assurance Organization}

The RU issued special inspection report IR-00-005 that assessed the independence of the QA Organization. Two Findings (documented in a Notice of Finding) were identified:

- The Project QA Manager did not have sufficient organizational freedom as indicated by the reassignment of the Project QA Manager by the General Manager, even though the Project QA Manager reported directly to the Corporate QA Manager and not the General Manager; and,

- The Project QA Manager presented a Stop Work Order to the Deputy Project Manager. However, the Deputy Project Manager did not consider the Stop Work Order appropriate, did not stop work, and did not appeal the action to the BNFL Corporate QA Manager, as required by procedures.

Additionally, the inspectors observed the reassignment of the Project QA Manager by the General Manager had a chilling effect on some BNFL Inc. employees in that they indicated they would be reluctant to take potential safety issues to management due to concern about retaliation.

These Findings and Observation are the most significant programmatic issues identified to date by RU inspection of BNFL Inc. The Findings have some similarity to those that were reported by the regulators at the BNFL Sellafield site. BNFL was requested to provide a written response to the Findings and the Observation within 30 days, in accordance with the instructions provided in the Notice of Finding.

\section{Review of the BNFL Part B-1 Facility and Process Design Deliverables}

At the request of the Office of River Protection (ORP), the RU completed its review of BNFL's Part B1 Facility and Process Design Deliverables. The RU review team was comprised of RU staff, RU contractors, and U.S. Nuclear Regulatory Commission (NRC) staff of the Special Projects Branch.

The RU reviewers determined that the Contractor facility and process design documents were not at a level of detail required to support the Hazards Analysis Report (HAR) or the Preliminary Safety Analysis Report (PSAR). In the absence of the required information regarding which standards BNFL had invoked, it was not possible to determine if the design achieved adequate safety. Additional design 


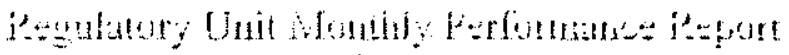

information required to support the Construction Authorization Request (CAR) included further development of the design integrated with identification of items that have been determined important to safety. The reviewers noted that the time required to develop this information could impact the schedule for future regulatory submittals.

\section{Topical Meeting on the Implementation of Integrated Safety Management (ISM) Cycle 2}

The subject of the May Topical Meeting between BNFL and the RU was Implementation of Integrated Safety Management (ISM). BNFL described the design basis for ISM and the process they were using to implement ISM in the design of their Pre-Treatment, High-Level Waste, and Low Activity Waste facilities. Using examples for all three facilities, BNFL described the ISM process of selecting preliminary hazards, controls, Design Basis Events (DBEs), and the resulting design standards. The ISM process resulted in identification of multiple DBEs for each of the three facilities, and the identification of controls and standards to mitigate the consequences from such events.

While BNFL presented numerous examples of how they had applied ISM, the RU expressed concern that the Contractor may not have fully adhered to its ISM design guide for several parts of the ISM process. Specifically, the presentation did not provide an adequate demonstration of application of the ISM design guide to selection of DBEs and implementing standards. Based on these concerns, the RU requested that BNFL present additional information relative to selection of DBEs, establishment of design requirements from the DBEs, and selection of implementing standards at the June Topical Meeting.

The RU also requested for the June Topical Meeting that BNFL address all of the remaining open issues from the previous Topical Meetings to bring closure to as many of the open issues as possible leading up to submittal of their CAR (expected in early calendar year 2001). The June Topical Meeting is the next to last topical meeting scheduled for Part B-1.

\section{Acceptability Review of the BNFL RPP for Design and Construction}

The RU completed its acceptability review of the BNFL RPP for Design and Construction. During the one-week acceptability review, the RU determines if the submittal includes the contract-required material and if the scope of the material is sufficient to conduct a detailed review. The RU determined the document was not acceptable for continued (detailed) review. The acceptability review determined that the scope of some of the submittal was insufficient. When notified of the deficient scope, BNFL withdrew the submittal.

\section{Review of the BNFL Non-radiological Worker Safety and Health Plan}

The RU continued its review of the BNFL Non-radiological Worker Safety and Health Plan that defines the BNFL construction safety program. The RU has issued two sets of questions. The question sets incorporated Occupational Safety and Health Administration, Region 10 comments on the Plan. BNFL and the RU discussed the questions and potential acceptable responses. The RU has completed a draft evaluation of the Safety and Health Plan, pending receipt of responses to the RU's questions. 


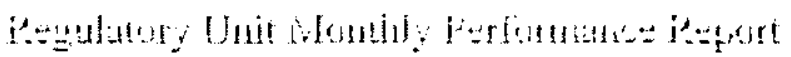

\section{ISMP Assessment Report}

The RU issued a report that documented the results of an assessment of the implementation of BNFL's ISMP. The report reflects aggregation of information from six inspections, nine design review reports, the RPP evaluation report, the QA Program and Implementation Plan evaluation report, three safety evaluations for authorization basis amendments, and observation of Contractor ISM Cycle II Reviews.

The RU found that, for the most part, the Contractor was adequately implementing its ISMP in a manner that was compatible with DOE P 450.4. However, in the area of authorization basis maintenance, the Contractor did not effectively allocate resources, clearly define the work, or perform the work within established controls. Furthermore, the lack of procedural adherence was a common problem, generally, for design-related work. The lack of adherence to the Contractor's hazard analysis procedures resulted in concern that the hazards analysis for the upcoming Construction Authorization Request (CAR) submittal may be unacceptable. Moreover, the Contractor's authorization basis maintenance procedures did not adequately identify and prioritize specific tasks, operations, or work items

\section{Self-assessment of the RU's Readiness-to-Proceed into Part B-2 of the RPP-WTP Contract}

The RU performed a self-assessment to determine if management systems and processes were in place to accomplish assigned regulatory functions. The self-assessment examined ten areas of interest against specific review criteria. The team reviewed project documents and interviewed personnel from the RU and its support contractors, U.S. Department of Energy Richland Operations, Office of River Protection (ORP), DOE-Headquarters, the NRC, and BNFL Inc.

In general, the team concluded that the RU management systems and processes were in place to accomplish the RU's responsibilities during Part B-2 and that the RU was effectively managing the regulatory program. In particular, the RU was accomplishing its regulatory responsibilities as outlined in the Regulatory Plan, which defines implementation of the Policy and the Memorandum of

Agreement. In all, 20 recommendations for improvement were summarized in the report. It should be recognized that the recommendations offered were for a program that overall was working well and thus were offered in the spirit of make the RU even more effective.

\section{EIR Team Assessment of DOE Readiness-to-Proceed into Part B-2}

The RU supported the EIR Team, a Congressionally chartered and funded group of senior industry managers, in its assessment of DOE's readiness to proceed with Part B-2 of the RPP-WTP Contract. The EIR Team concluded that the RU was ready to proceed into Part B-2 and identified no concerns associated with the safety regulation of the RPP-WTP by the Regulatory Unit. The EIR Team also concluded that with the change in project approach, the recent decision to terminate the BNFL Inc. contract might impact the regulatory regime. The EIR Team recommended that DOE provide a stable nuclear regulatory environment, which included independent standards-based regulation. 


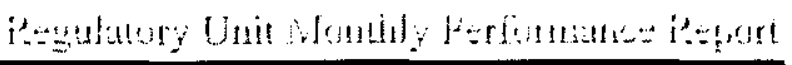

While the EIR Team concluded that the area of Nuclear Regulation was ready to proceed with Part B2, the Team determined the areas of Project Management, Business and Finance, and Contracting had significant deficiencies. They noted that ORP was facing significant challenges in being ready to proceed by August 2000, even if an acceptable bid had been submitted.

\section{Quarterly Briefing}

The Regulatory Official met with representatives of DOE Headquarters in Washington D.C. to present the $14^{\text {th }}$ quarterly briefing of regulatory activities in support of the BNFL TWRS-P Waste Treatment Plant (WTP). Topics presented included the following:

- Schedule of Safety Deliverables

- EIR

- RU review of B-1 deliverables

- Results of Topical Meetings held with BNFL

- ISM Cycle 2 status

- Status of the Inspection Program

- Authorization Basis Alignment

- Implementation of the IH\&S Program

No actions resulted from the briefing. 


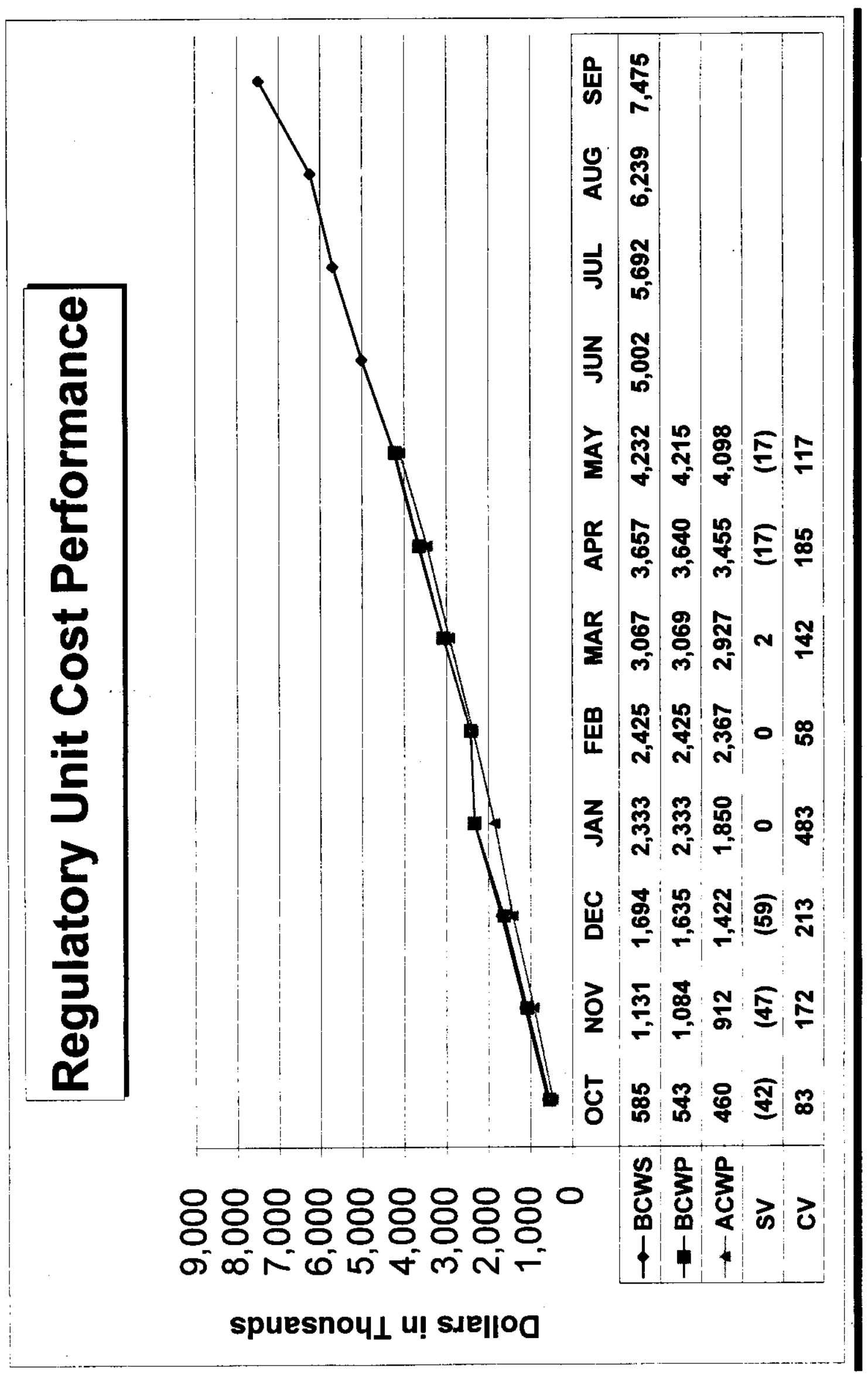




\section{COST PERFORMANCE SUMMARY}

The fiscal year-to-date cost through May reflects a favorable cost variance of $\$ 119 \mathrm{~K}$. This variance is a result of lower than anticipated costs associated with Authorization Basis Maintenance, Topical Issue Resolution, development of CAR Review handbooks, and Inspection Oversight Guidance. The RU's current baseline reflects an approximate $\$ 900 \mathrm{~K}$ scope deferral into FY 2001 as documented in approved Change Request RU-2000-007. All activities are currently performing on or are very close to the baseline schedule.

\section{NEAR-TERM LOOK AHEAD}

\section{June}

- Issue LCA Review Handbook

Planned Due Date

- Commence Review of BNFL LCA Request

$6-13-00$

- Commence Review of BNFL QAPIP

- Conduct Topical Closeout Meeting

- Issue Revised Openness Plan

$6-27-00$

- Issue SAP Review Handbook

\section{July}

- Begin review of Contractor's resubmitted RPP for Design and Construction

$7-10-00$

- Conduct QA Inspection

$7-17-00$

- Issue ER on BNFL IH\&S Program Description

$7-21-00$

- Conduct Topical Meeting on Seismic PRA

$7-25-00$

\section{August}

- Conduct ALARA Inspection

8-07-00

- Present $15^{\text {th }}$ Quarterly Briefing to Headquarters

$8-17-00$

- Issue QA Inspection Report

8-18-00 


\section{PROGRAM PERFORMANCE OVERVIEW}




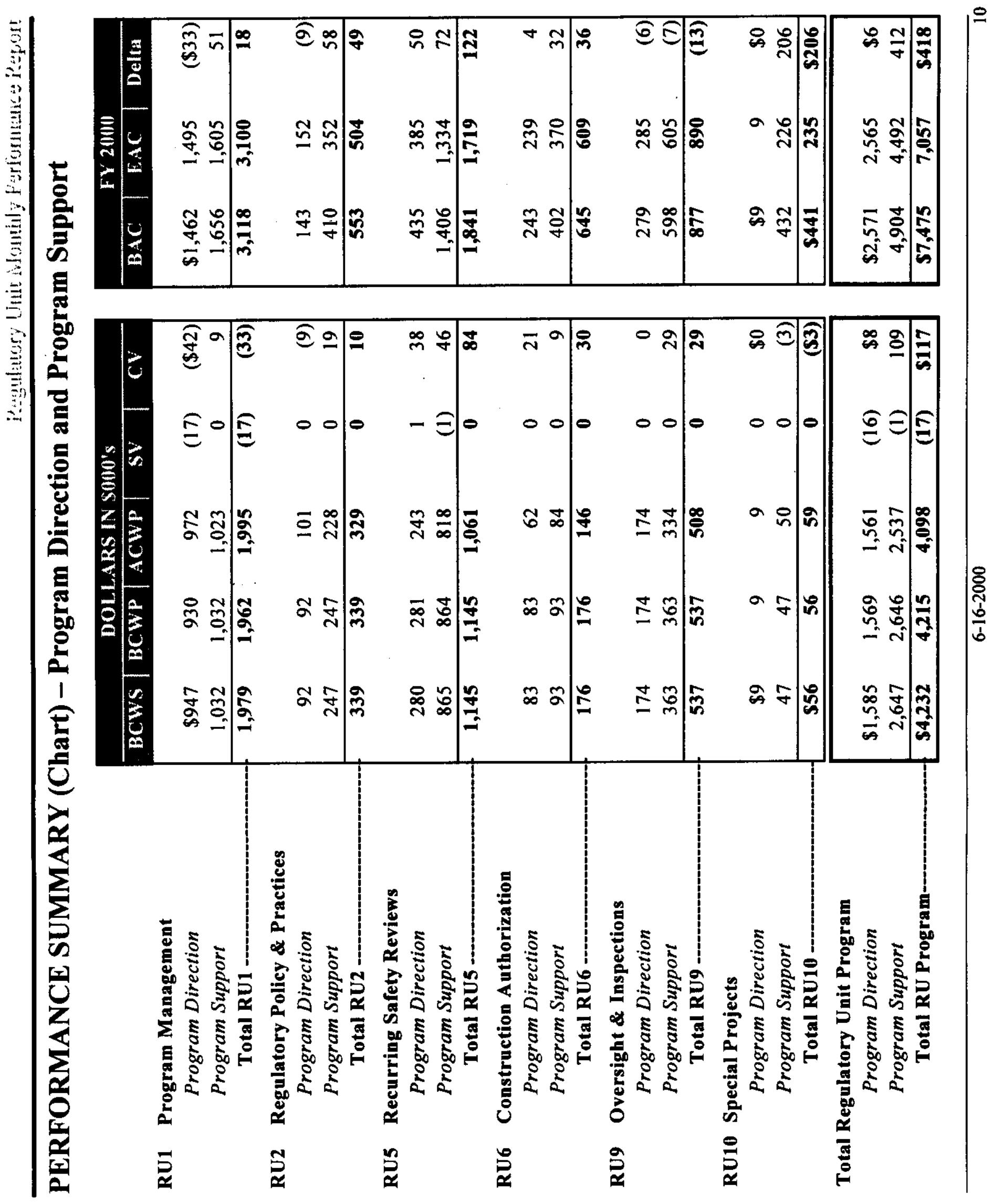




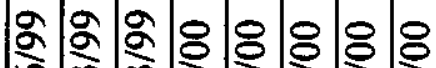

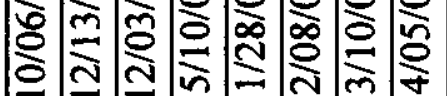

2. 2. ‡ m

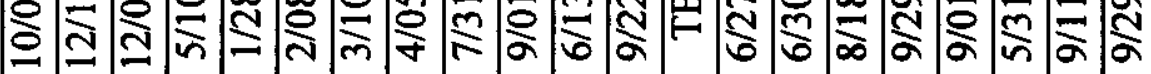

\begin{tabular}{llllllll}
-1 & & & & & & & \\
\hline
\end{tabular}

离

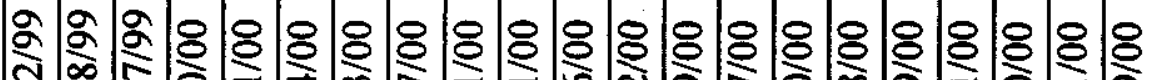
స్

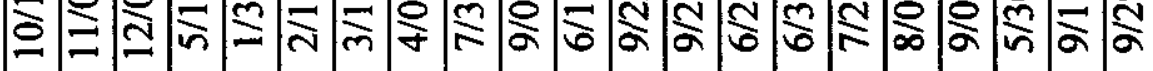

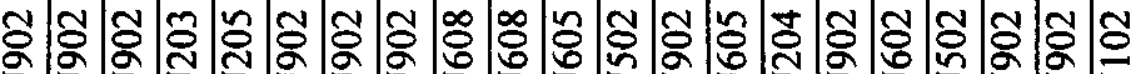

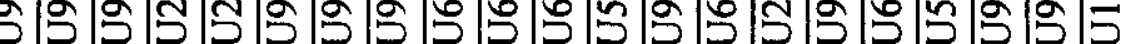

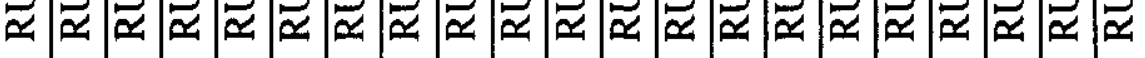

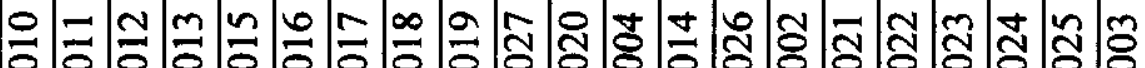
全全

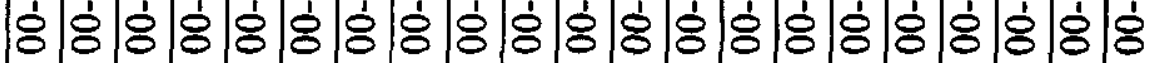

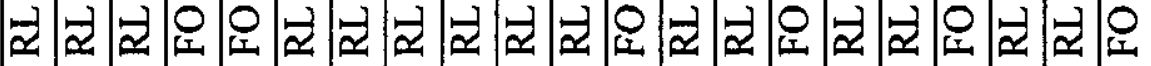



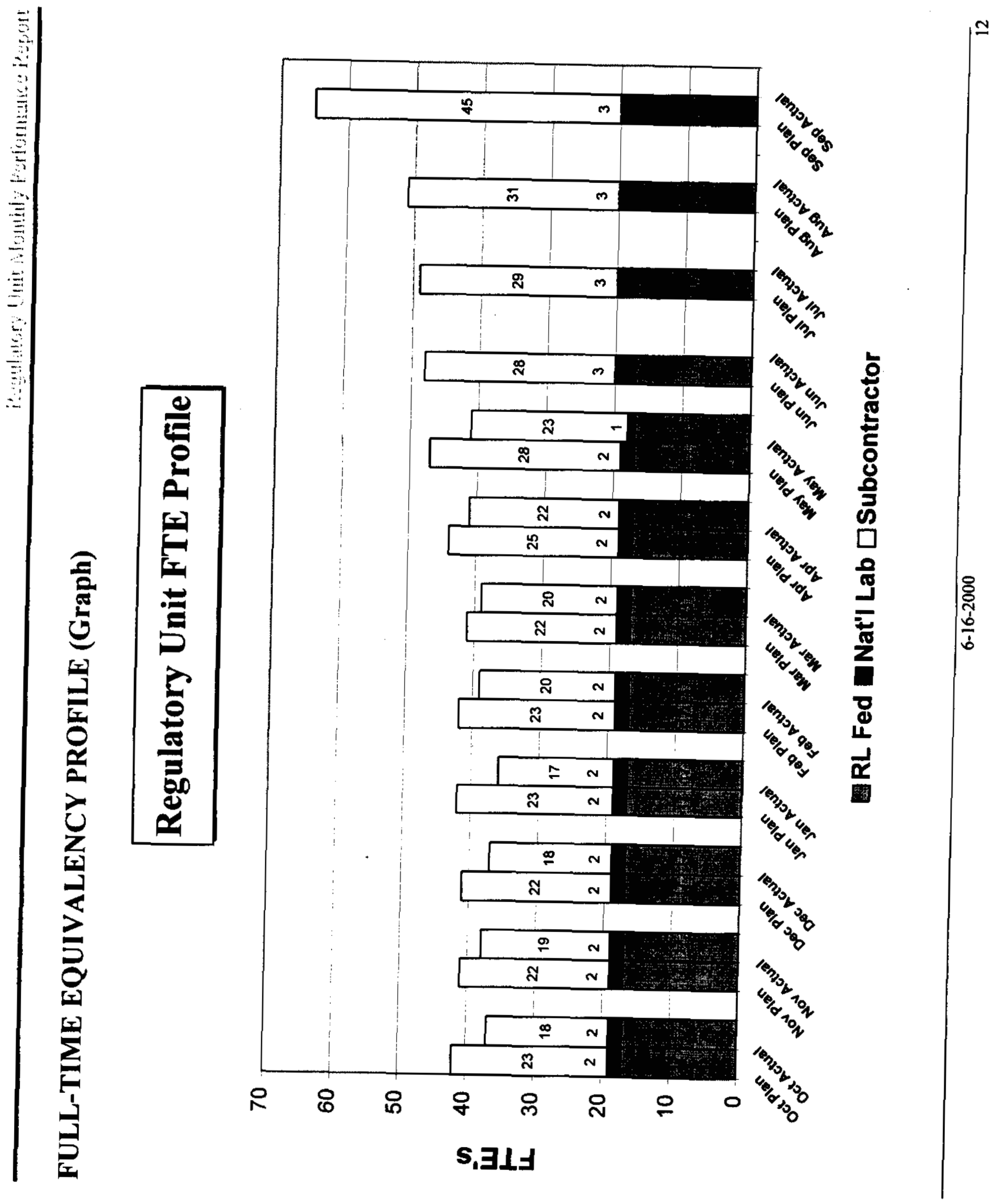


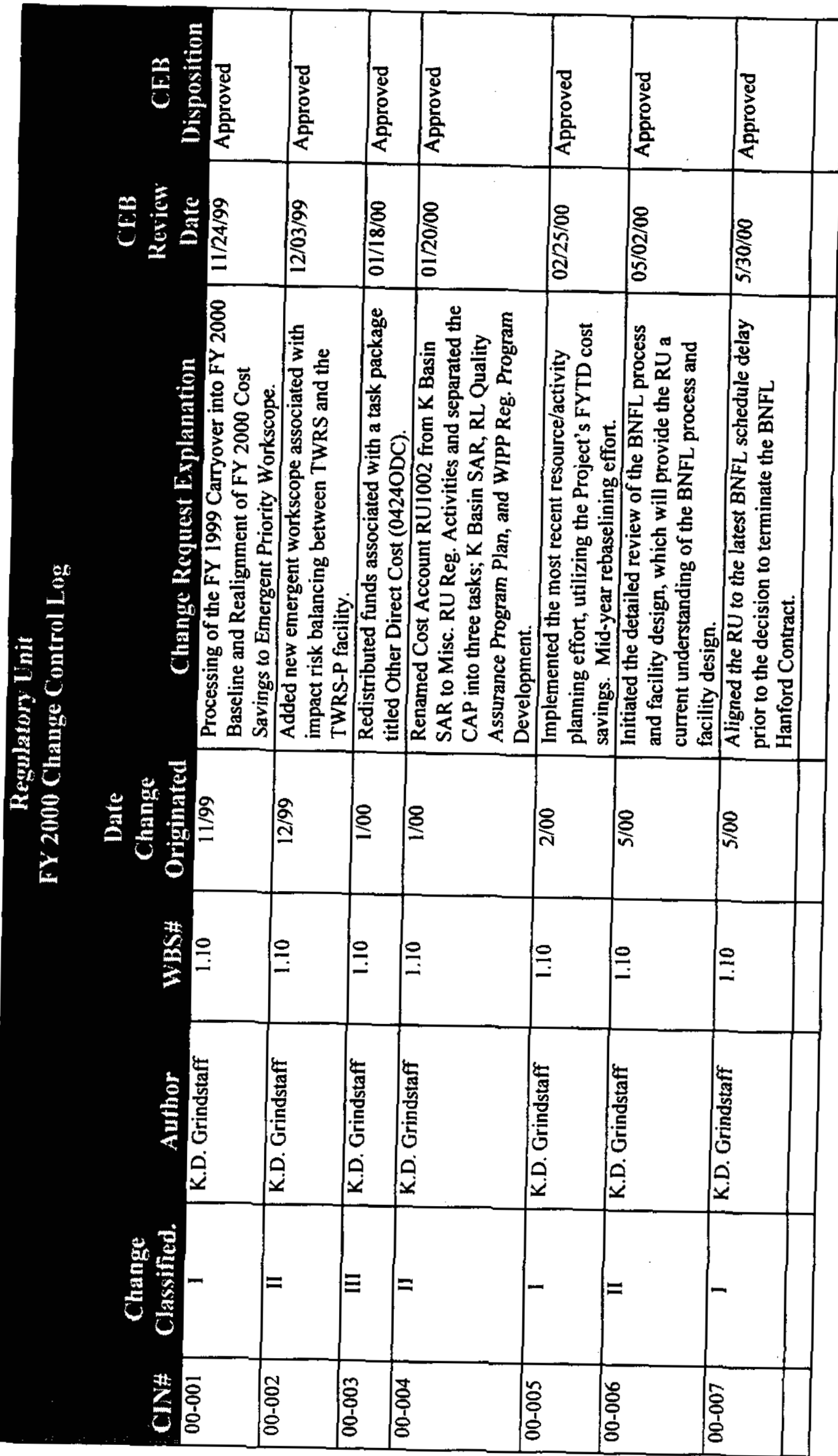




\section{GLOSSARY}

Actual cost of work performed (ACWP): The actual cost incurred and applied or distributed for the work performed within a given time period. It includes all labor categories, material, any other direct costs, subcontract work, and function overhead.

Approved baseline: The budget authorized to perform the workscope that has been agreed upon by the customer and the contractor(s). It is portrayed in the Multi-Year Work Plan with all approved changes. This baseline may or may not be fully funded, and could be more or less than the compliance baseline.

Budget at completion (BAC): The sum of budgets established to complete a program and/or project or any component of a program and/or project.

Budgeted cost of work performed (BCWP): The value for completed work measured in terms of the planned budget for that work. It is synonymous with earned value.

Budgeted cost of work scheduled (BCWS): The time-phased budgeted value of work scheduled to be accomplished over a given time period. The BCWS for a total cost account through its entire period of performance is equal to the BAC for the cost account.

Carryover Workscope: The estimated dollar amount of the workscope that was not completed during the fiscal year and which will be carried over and completed in the next fiscal year.

Compliance baseline: The budget that is required to perform the workscope necessary to be in compliance with State and Federal regulations, enforceable agreement milestones, and DNFSB milestones. The level of activity required to be in compliance assumes sufficient funding. Note: Because approved baselines are considered to be compliant, this column will likely be eliminated.

Contract Inherited: The assumed budget for the planned scope of work at the time a new contract is signed by the company responsible for performing the work.

Cost variance (CV): The difference between $B C W P$ and $A C W P(C V=B C W P-A C W P)$. At any time, it shows whether the work actually performed has cost more or less than the amount budgeted for the same work.

Cost Performance Indicator (CPI): The CPI is the ratio of BCWP to ACWP, or (BCWP/ACWP).

Earned value (EV): The periodic, consistent, and objective measurement of work performed in terms of the budget planned for that work. The EV is synonymous with the BCWP and it is compared to the BCWS to obtain schedule performance and to the ACWP to obtain cost performance. 


\section{GLOSSARY (CONTINUED)}

Estimate at completion (EAC): Cost allocated to the work breakdown structure element to date, plus the estimate of costs for authorized work remaining. Authorized work remaining includes any undistributed budget.

Fiscal Year Spending Forecast (FYSF): The estimated total that will be spent from October through September (current Fiscal Year).

Funding carryover and new Budget Authorization (BA): This funding represents both the funding allocated to perform workscope planned in the prior fiscal year, not completed, and approved to be performed in the current fiscal year, as well as new BA to perform the approved baseline workscope.

Funding target: The level of funding that is anticipated (as a result of the Integrated Priority List process) in a given Fiscal Year based on an assumed funding level for the Site.

Multi-Year Work Plan - 10/1/XX: The Project's approved cost/schedule/technical baseline at the beginning of the fiscal year.

Project Execution Module (PEM): The Project Execution Module (PEM) of the Integrated Planning, Accountability, and Budgeting System-Information System (IPABS-IS) replaces the Progress Tracking System (PTS) as EM Headquarters' centralized system for reporting financial, milestone, performance, and other execution-year information for PBSs, sub-PBSs, TTPs, and line item construction projects. In addition, this module collects mid-year and year-end actual performance information against the agreed upon management commitments for the current execution year.

Schedule Performance Indicator (SPI): The SPI is the ratio of BCWP to BCWS, or (BCWP/BCWS).

Schedule variance (SV): The difference between BCWP and BCWS (SV = BCWP - BCWS). At any time, or for a given period of time, it represents the difference between the planned dollar value of work actually accomplished and the value of the work scheduled to be accomplished.

Work breakdown structure (WBS): A product-oriented family tree division of real estate, hardware, software, services, and data products that organize, define, and display all of the work to be performed in accomplishing the program and/or project objectives. 